UNIVERSIDADE DE SÃO PAULO - USP

FACULDADE DE FILOSOFIA, LETRAS E CIÊNCIAS HUMANAS DEPARTAMENTO DE LETRAS CLÁSSICAS E VERNÁCULAS

PROGRAMA DE ESTUDOS COMPARADOS DE LITERATURAS

DE LINGUA PORTUGUESA

JANE ADRIANE GANDRA

PINHEIRO CHAGAS, UM ESCRITOR OLVIDADO

Versão Corrigida

SÃO PAULO - SP

$\mathrm{MAIO} / 2012$ 
UNIVERSIDADE DE SÃO PAULO - USP

FACULDADE DE FILOSOFIA, LETRAS E CIÊNCIAS HUMANAS

DEPARTAMENTO DE LETRAS CLÁSSICAS E VERNÁCULAS

PROGRAMA DE ESTUDOS COMPARADOS DE LITERATURAS

DE LINGUA PORTUGUESA

JANE ADRIANE GANDRA

\section{PINHEIRO CHAGAS, UM ESCRITOR OLVIDADO}

Tese apresentada ao Programa de PósGraduação em Estudos Comparados de Literaturas de Língua Portuguesa, do Departamento de Letras Clássicas e Vernáculas da Faculdade de Filosofia, Letras e Ciências Humanas da Universidade de São Paulo, como exigência para a obtenção do título de Doutor em Letras.

Orientador: Prof. Dr. Paulo Fernando da Motta de Oliveira

Versão Corrigida

SÃO PAULO - SP

MAIO/2012 
Autorizo a reprodução e divulgação total ou parcial deste trabalho, por qualquer meio convencional ou eletrônico, para fins de estudo e pesquisa, desde que citada a fonte.

Faculdade de Filosofia, Letras e Ciências Humanas da Universidade de São Paulo

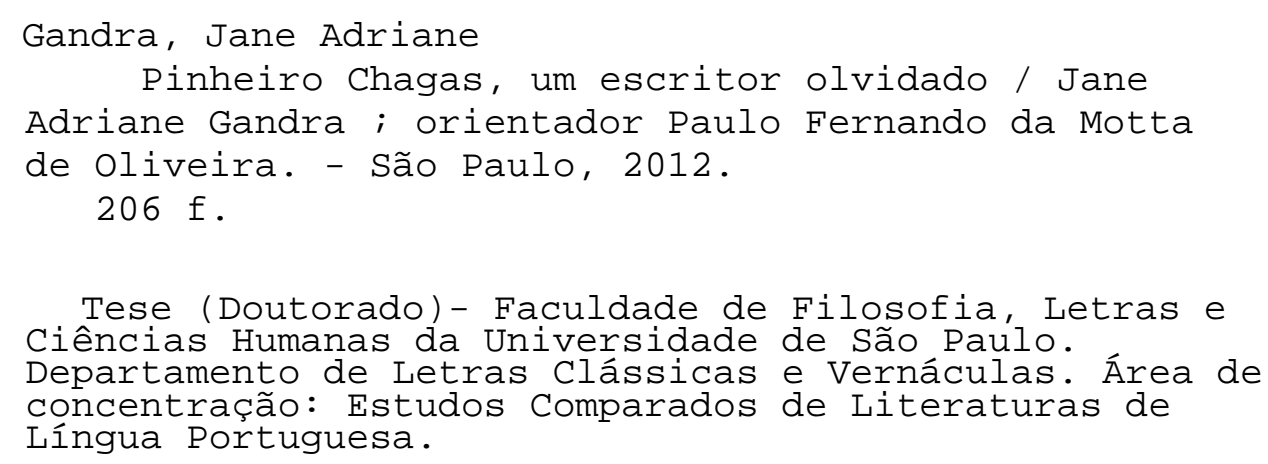

1. Manuel Pinheiro Chagas. 2. Romance Histórico. 3. Romantismo. 4 Realismo. 5. Crítica Literária. I. oliveira, Paulo Fernando da Motta de, orient. II. Título. 
Ao meu filho, Dante, que me ensinou a beleza da vida.

À Marleuza, minha mãe, companheira constante e fiel de toda a minha vida, pelos seus conselhos e pelo seu nunca desmentido exemplo. 


\section{AGRADECIMENTOS}

Ao CNPQ, pela concessão de bolsa de estudos, que favoreceu a elaboração desta pesquisa.

A todos os amigos que souberam compreender a minha ausência.

À Eliane Junqueira, pela amizade e pela atenção que sempre dispensou às referências sobre Pinheiro Chagas.

A Thiago Veloso, pelas traduções.

À Adriana Tolentino, pela formatação deste trabalho.

Ao Prof. Dr. Hélder Garmes, pelos empréstimos de seus livros.

Ao Prof. Dr. José Cândido Martins, pelo envio dos livros de teoria sobre romance histórico e os que faltavam no conjunto da obra de Pinheiro Chagas.

Aos professores Dr. Eduardo Vieira Martins e Hélder Garmes, no momento da qualificação, agradeço, por uma série de indicações proveitosas e interessantes na melhoria deste estudo.

Ao Prof. Dr. Paulo Motta de Oliveira, todo o meu apreço, admiração e gratidão, pelo companheirismo constante e ajuda necessária, precisa e paciente.

Aos meus amores Mayalle, Vítor Hugo, Matheus, Maria Fernanda, Túlio, Lívia, Henrique e a pequena Júlia, pelas muitas alegrias compartilhadas.

À Tia Marlúcia, pelos conselhos na hora certa.

À Tia Ruth, pelo seu amor de todas as horas.

À Sheila, pelo seu otimismo, que me fez acreditar, não permitindo que eu desistisse.

À Janine, minha cunhada, por ter dado colo a Dante.

Ao meu irmão Janderson que, com sabedoria, serenou todas as tormentas.

À Jeanine e Aline, pelas vezes que chamei, e vocês vieram...

A Dante, que renovou as minhas forças, quando pensei que não mais existiam.

À minha mãe que é o meu espelho de coragem e superação.

A Deus, por ser o meu abrigo. 


\section{RESUMO}

Este estudo tem por objetivo refletir sobre uma figura literária pouco estudada, Manuel Pinheiro Chagas (1842-1895), escritor português considerado pela crítica principalmente como romancista histórico. Ao eleger o romance histórico como narrativa romântica, parece que Chagas tenta disputar espaço com o romance realista/naturalista, mesmo depois da consolidação do Realismo. Por meio da análise de quatro de seus romances, A virgem Guaraciaba (1865), A máscara Vermelha (1873) e a sua continuação O juramento da Duquesa (1873), e A descoberta da Índia. Contada por um marinheiro (1890), verificamos como o projeto literário deste escritor, que se inicia com a efabulação da História, vai convergindo para um realismo pouco romantizado, que ele denominou de estudo histórico romântico.

Palavras-chave: Manuel Pinheiro Chagas - Romance Histórico - Romantismo - Realismo - Crítica Literária 


\begin{abstract}
This study is intended to reflect about the literary understudied character, Manuel Pinheiro Chagas (1842-1895), portuguese writer considered by public opinion mainly as historical novelist. Choosing the historical novel as romance narrative, seems that Chagas tries to establish space with the realistic/naturalist novel, even after the Realism consolidation. Analyzing four of his novels, A virgem Guaraciaba (1865), A máscara Vermelha (1873) and its continuation O juramento da Duquesa (1873), and A descoberta da Índia. Contada por um marinheiro (1890), we could verify how the literary project from this author, that initiates itself with the history creation, starts to converge to a type of less romanticized realism, that he defines as romantic historical study.
\end{abstract}

Keywords: Manuel Pinheiro Chagas - Historical Novel - Romanticism - Realism Literary Criticism 


\section{TABELAS DE SIGLAS DAS OBRAS DE PINHEIRO CHAGAS ${ }^{1}$}

ACDJ - A corte de D. João V ( [1867] 2002), $2^{\mathrm{a}}$ ed.

ACP - A conspiração de Pernambuco ([1866] 1870), $2^{\mathrm{a}}$ ed.

ACPS - As colônias portuguesas no século XIX (1890), $1^{\mathrm{a}}$. ed.

ADFS - As duas flores de sangue ([1875] s.d), s.ed.

ADI - A descoberta das Índias ([1890] 1898), s. ed.

AFS - A flor seca ([1866] 1904), s.ed.

AJVR - A joia do Vice-Rei ([1890] s.d), s.ed.

AMB - A mantilha de Beatriz ([1879] s.d), $6^{\text {a }}$ ed.

AMI - A Marquesa das Índias (1890), $1^{\text {a }}$ ed.

AMV - A máscara vermelha (1873] s.d), s.ed.

AVG - A virgem Guaraciaba ([1866] s.d), s.ed.

DP - Dicionário popular (1880), 6º vol. s.ed.

EC - Ensaios críticos ([1866] s.d), s.ed.

FT - Fora da terra (1878), s.ed.

GM - Os guerrilheiros da morte ([1872] 1874), 4 a ed.

HAP - História alegre de Portugal (1880), $4^{\mathrm{a}}$. ed.

HDP - História de Portugal, ([1878] 1899), 3ª ed.

NEC - Novos ensaios críticos ([1867] 1890), s.ed.

ODM - Os dramas do mar (1874), s.ed.

OJD - O juramento da Duquesa ([1873] s.d), s.ed.

OMN - O Major Napoleão (1867), s.ed.

ONVS - O naufrágio de Vicente Sodré ([1892] 1910), 2ª ed.

OSV - O segredo da Viscondessa ([1871] s.d), s.ed.

OTL - O terremoto de Lisboa ( [1874] s.d), s.ed.

TBM - Tristezas à beira-mar ([1866] 1973), s.ed.

UEC - Um enredo a Calderón ([s.d] 1910), $2^{\mathrm{a}}$. ed.

VBA - Vermelhos, Brancos e Azuis ([187?] s.d), 1ª ed.

\footnotetext{
${ }^{1}$ As citações dos livros que fazem parte do acervo de Pinheiro Chagas serão feitas com as iniciais dos títulos dos volumes e segundo as edições utilizadas, conforme se apresentam acima.
} 


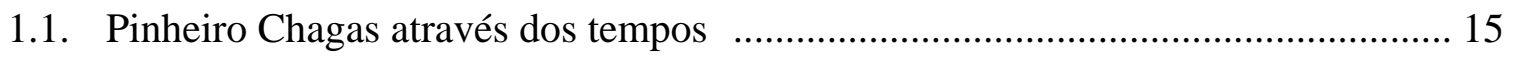

CAPÍTULO II: PINHEIRO CHAGAS: HISTÓRIA E FICÇÃO................................ 33

2.1. Uma introdução ao romance histórico ............................................................... 33

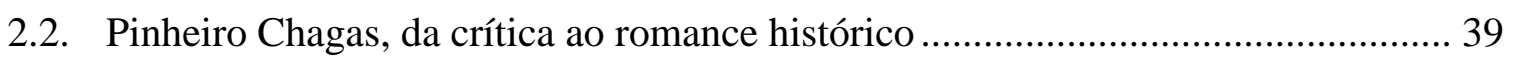

2.2.1. Os senões aos romances históricos de Arnaldo Gama ............................................ 43

2.2.2. Duas histórias dramatizadas: uma de Camilo Castelo Branco e outra de Antonio

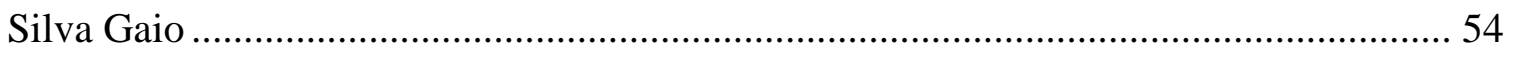

2.3. O romance histórico, um projeto literário .......................................................... 72

CAPÍTULO III: O ROMANCE HISTÓRICO DE PINHEIRO CHAGAS................102

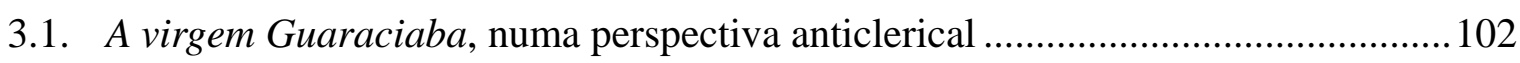

3.1.1. As portuguesas de Pinheiro Chagas, devotas ou afrancesadas ...............................111

3.2. A máscara vermelha e O juramento da Duquesa: A tragicomédia da Restauração132

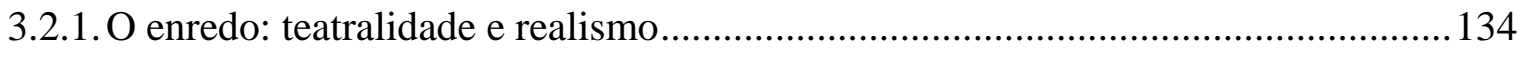

3.2.2. Os atores da tragicomédia da Restauração............................................................. 149

3.3. História dramatizada: A descoberta da Índia. contada por um marinheiro .............162

3.3.1. Bastião Fernandes, um contador de histórias com História ....................................172

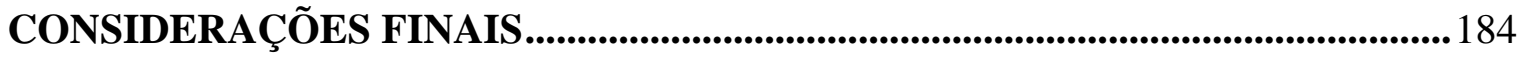

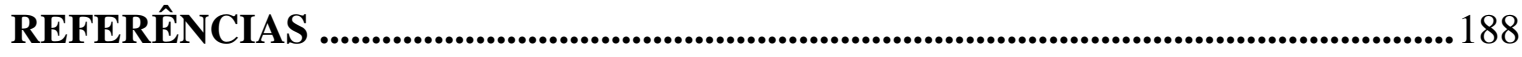

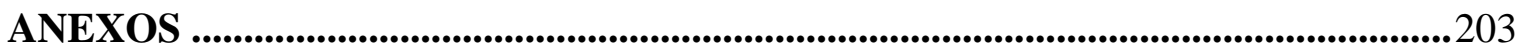


Parece-nos que nesta coisa chamada hoje de romance histórico há mais história do que nos graves e inteiriçados escritos dos historiadores (Alexandre Herculano, 1851)

A realidade deixa a perder de vista as mais opulentas imaginações. (Calderón, personagem histórica/inventada de A mantilha de Beatriz, 1879) 


\section{PRIMEIRAS PALAVRAS}

As histórias literárias são constantemente permeadas de disputas, e as de Portugal não são diferentes. O século XIX foi particularmente fecundo em controvérsias. Naquele período o que efetivamente importava para os contendores era o exercício retórico ${ }^{2}$, a tentativa de destruir os adversários pelo constrangimento da argumentação e, fatalmente, com isso, alcançar a notoriedade com a desmoralização intelectual dos opositores, que eram expostos ao ridículo. Assim, por quaisquer motivos, publicados sob variados gêneros, os confrontos por vezes giravam em torno de divergências políticas ou literárias, disputas pelo mercado editorial, até mesmo por razões mesquinhas, como vinganças, invejas, rancores e ódios.

Diante do exposto, a primeira pergunta que se impõe é: até que ponto isto não prejudica a produção literária de um autor? Como percebemos em nossa dissertação de mestrado, Manuel Pinheiro Chagas (1842-1895), escritor português, foi antes de tudo um polemista, que discutiu desde assuntos irrelevantes a questões políticas e estéticas com a Geração de 70 e com Eça de Queirós.

Eça, como grande opositor de Chagas, enfrentou-o em duas importantes controvérsias: Brasil e Portugal e A relíquia. Embora alguma crítica seja favorável às considerações de Chagas nestas querelas, o que se depreende é que nessas disputas venceu o autor de $O$ crime do padre Amaro. E, a partir de então, o apagamento da figura literária de Pinheiro Chagas pareceu inevitável, pois sua imagem ficou associada a uma posição reacionária e conservadora. Também as suas preferências literárias devem ter ajudado no seu silenciamento, se considerarmos que a sua opção pelo romance histórico - então com apelo popular contribuiu para a cristalização de uma imagem redutora dele enquanto romancista.

Posto isto, consideramos que Pinheiro Chagas, como um escritor pertencente a um mercado restrito - pois, de um lado, havia a produção gigantesca de Camilo e, de outro, o romance realista de Eça ${ }^{3}$-, tenha elegido o romance histórico como narrativa romântica para disputar espaço. Parece que Chagas entendia que o romance histórico se aproximava do romance realista na medida em que os dois gêneros pretendiam provocar um efeito de realidade, só que o primeiro observando os costumes do passado e o segundo os do presente.

\footnotetext{
${ }^{2}$ Ver Ventura, 1991. Este autor faz uma análise importante sobre as polêmicas literárias ocorridas em fins do século XIX e início do XX no Brasil. Ventura, com este estudo, esclarece que, antes de tudo, a finalidade da polêmica no circuito literário é colocar em destaque o nome do debatedor, mantendo-o constantemente em evidência. Geralmente, nestes opúsculos, encontram-se discussões vazias, prolixas e intermináveis.

${ }^{3} \mathrm{Cf}$ Júdice, Prefácio de Julieta, 1985, s.p. No primeiro capítulo, voltaremos a discutir sobre as considerações deste crítico no que se refere ao ostracismo de Pinheiro Chagas.
} 
Preocupado com o realismo dos quadros reconstruídos do passado nacional, Chagas recorreu aos elementos cênicos, objetivando dar mais vivacidade ao episódio. Possivelmente, esta utilização de técnicas teatrais em seu romance histórico aproxima-se do pensamento de Hegel ([18?] 1964, p.375), que defendia que para a existência da ação dramática são necessários ação e reação como na ação histórica.

Assim, com este estudo se pretende reavaliar a obra do escritor Manuel Pinheiro Chagas, que foi pouco estudado pelas histórias literárias, de maneira a ressaltar as suas qualidades estéticas, para que justifiquem uma revisitação de sua obra literária. Além disso, demonstraremos que Pinheiro Chagas, como a Geração de 70, contestou a estrutura política e social em Portugal, desde o período das descobertas, evidenciando que o atraso nacional em relação à Europa devia-se ao despotismo monárquico e ao jesuítico.

Porém, antes de qualquer análise sobre sua ficção, procuramos na primeira parte desta tese apresentar a fortuna crítica do autor, que - se comparada à de outros escritores do período - parece ser restrita. Desta forma, para que o leitor possa visualizar melhor a trajetória da imagem deste escritor por entre os tempos, de início, apresentamos as considerações de alguns intelectuais de sua época, seguindo com as de outros do século XX, até que possamos ressaltar algumas citações de importantes estudos nos dias atuais.

Num segundo momento, pensando na complexidade de definição do romance histórico - gênero que ocupa a maior parte da produção literária de Pinheiro Chagas -, compreendemos que seria importante uma introdução sobre as particularidades que orientam este tipo de ficção. Nesse capítulo, além de apresentarmos as teorias de especialistas na matéria, como Barbara Foley (1986), Célia Fernández Prieto (2003) e György Lukács (2011), entre outros, também analisamos as concepções no gênero do próprio Pinheiro Chagas, o que pôde ser feito estudando alguns de seus textos. Para tanto, de muito nos valeu para a elucidação desses pressupostos a sua crítica literária realizada sobre outros romances históricos de seu tempo.

No entanto, o cerne desta parte consiste na aproximação que fazemos entre as proposições defendidas por alguns representantes da Geração de 70, como Antero de Quental e Oliveira Martins, no que tange aos fatores que contribuíram para a decadência do país. Para o primeiro autor, três foram as causas: a monarquia absoluta, o Concílio de Trento e o expansionismo marítimo. Antero e Chagas partilham as duas primeiras citadas, a divergência de opinião estaria no último motivo, uma vez que, para este, teria sido a perda da nacionalidade para Espanha, depois do desastre de Alcácer Quibir, a terceira causa. Já Oliveira Martins chega às mesmas conclusões de Pinheiro Chagas quanto à ruína nacional estar relacionada aos planos dos estadistas que, educados pelos jesuítas, converteram Portugal 
numa nação devota e alienada. Além disso, para ambos, a casa de Bragança promoveu por meio das alianças com o estrangeiro, particularmente com a Inglaterra, a perda das colônias, que foi o tiro de misericórdia num país há muito adormecido.

Já no terceiro capítulo, analisaremos quatro romances históricos de Pinheiro Chagas, enfocando primeiramente a obra que é representante de sua primeira fase, que denominamos de aprendizagem ou experimental: A virgem Guaraciaba. Isto porque, já aqui, além dos ingredientes românticos que dão outros matizes ao romance histórico - como amores não correspondidos, duelos entre heróis, crimes passionais que levam as personagens a professar, desejo de vinganças e a loucura -, há também uma incipiente técnica de desromantizar os vultos históricos, humanizando-os, de certa forma. Tal assertiva pode ser facilmente comprovada na maneira como são construídas as imagens de duas grandes personalidades desse tempo revisitado: Pe. José de Anchieta e Pe. Antonio Vieira.

Ademais, não podemos nos esquecer do caráter moralizante do romance histórico que, apesar de ter a sua ação no passado, objetiva intervir no presente. Assim, Beatriz de A virgem Guaraciaba é a representação da mulher portuguesa do último quartel da centúria orientada pelo clero. Órfã, educada nos rigores da religião, ela é facilmente agenciada pelos jesuítas na conversão do chefe indígena. Mas essa mesma alienação que padece Beatriz pode ser visualizada em outra heroína, Amélia, de O crime do padre Amaro, vítima também de sua devoção mítica. Por outro lado, Beatriz já sinaliza uma mudança na concepção da heroína de Chagas. Embora esta personagem tenha muitas características românticas, ela surpreende o leitor ao optar subversivamente pelo suicídio na frente de um dos seus preceptores. Dessa maneira, chama-nos à atenção alguns tipos do feminino de Chagas que se destacam pela astúcia, virilidade e voluptuosidade, distanciando-se desse arquétipo romantizado, sendo, por vezes, capitais para o movimento da trama. Por outro lado, a mulher, fortemente importante nas primeiras duas fases, já na terceira, é quase insignificante a sua participação na intriga romanesca, perdendo força no estudo histórico romântico. Diante disso, pareceu-nos necessário refletir sobre o seu papel no projeto de nação concebido por este escritor, uma vez que a mulher está ligada ao destino de gerações futuras.

Passando ao segundo momento da escritura de Chagas, que nomeamos de intermediária, optamos por outros dois romances, A máscara vermelha e a sua continuação, O juramento da Duquesa. Ainda que haja, nestes dois romances, muita efabulação, eles parecem já indicar caminhos para a feitura do estudo histórico romântico, fórmula convencionada dos escritos da maturidade do autor. Chagas busca como mote para sua ficção um episódio bastante lacunar na História, em que personagens históricas, como Pedro Bonete e a Duquesa de Caminha, 
poderiam facilmente ser confundidas como ficcionais pelo leitor comum, já que suas histórias não são tão conhecidas como são as de outras figuras históricas, como é o caso de Francisco Lucena e Pe. Antonio Vieira. Por escolher os pontos obscuros da História, o romancista histórico ganha mais autonomia na criação, mais liberdade de invenção. Aqui, como na primeira fase, Chagas continua com o propósito “[...] não de celebrar os grandes feitos [...], mas de narrar os enredos da corte, as calúnias, as traições que se desenrolavam no reverso desse quadro brilhante das épicas pelejas e de sobre-humanas façanhas" (CHAGAS, OJD, [1873] s.d, p. 90). Particularmente, na análise sobre estes dois livros, pretendemos ainda demonstrar como Chagas se utiliza dos elementos do gênero dramático, objetivando dar movimento e um traço mais realístico possível às cenas narradas. Demonstraremos, ainda, a maneira como Pinheiro Chagas compara o episódio da Restauração a uma tragicomédia, pelo cenário grotesco que é instituído devido ao governo inerte e intolerante de D. João IV.

Como se verá, esta seleção do corpus, até aqui, objetiva demonstrar como a intriga romântica, que alinhava a parte histórica nas primeiras publicações de seus romances históricos, vai perdendo força para a História, tornando-se quase ausente nos livros da terceira fase. Desta maneira, para exemplificação do seu período de maturidade, elegemos $A$ descoberta da Índia. contada por um marinheiro. Sendo que, nestas últimas produções, sob o título de estudo histórico romântico, seu autor defende que se trata de história dramatizada. Ou seja, “[...] é simplesmente a história posta em ação, são as cenas verdadeiras, tais como as encontramos na prosa dos nossos cronistas [...]” (CHAGAS, AJVR, [1890], s.d, p. 7).

Essas publicações de 1890 são, certamente, originadas de um espírito de comoção nacional provocado pelo Ultimatum inglês. Mas este episódio político foi tanto um golpe mortal na identidade nacional, como um elixir que fez acordar da letargia toda a nação. O enredo escolhido para a terceira fase tem como pretexto discutir a política ultramarina inadequada promovida pelos estadistas portugueses, que transformaram o Estado e o soldado em verdadeiros comerciantes. Depois disso, era uma questão de tempo testemunhar a perda das possessões. Pelas discussões que Pinheiro Chagas estabelece desde 1866 em sua ficção sobre a questão colonial, ele figura dentre aqueles que anteviram no futuro deprimente de Portugal algo nas mesmas proporções do Ultimatum.

Feitas, então, as devidas escolhas e suas justificativas, esperamos que este estudo possa tentar desfazer ou, se não, amenizar a imagem negativa que recai sobre a obra de Pinheiro Chagas, de modo que se renove o desejo da releitura de seus romances, principalmente os históricos. 


\section{A FORTUNA CRÍTICA SOBRE PINHEIRO CHAGAS}

Neste capítulo, pretendemos verificar a fortuna crítica de Pinheiro Chagas, indicando os vários estudos que, mesmo analisado-a de forma superficial ou pouco fundamentada, trataram da obra desse escritor.

\subsection{Pinheiro Chagas através dos tempos}

Albert Thibaudet considera que a crítica tal qual se exerce hoje é “ [...] um produto do século XIX [...]” (1930, p.7 apud, ROGER, 2002, p.31), apesar de existir antes disso muitos juízos de valor que apresentavam uma extraordinária intuição em matéria de arte, como foram os de Aristóteles, Quintiliano, Boileu, Diderot, dentre outros.

A crítica a que se refere Thibaudet é a mesma que segue o modelo das ciências naturais, modelo transportado para as áreas artísticas, com o propósito de encontrar a essência da arte. Tanto assim, que Taine definiu o seu método analítico como sendo o naturalismo da alma quando toda produção artística estava passível de ser analisada sob a determinação da causa.

Especificamente no Portugal de Oitocentos, além da linha tainiana, havia mais dois procedimentos críticos que orientavam as avaliações sobre arte. O método biográfico de Saint-Beuve ${ }^{5}$ que, ao analisar uma obra, levava em consideração a intencionalidade do autor e os dados relevantes de sua vida. E outro que avaliava sob os pressupostos de uma crítica idealista $^{6}$, na exaltação da inspiração e da genialidade. Porém, ao lado desses modos de ver a arte também florescia um outro, sem princípios definidos, que muitas vezes era aquecida pelas fogueiras das vaidades e dos ódios, que incitaram inúmeras polêmicas desse período. Por

\footnotetext{
${ }^{4} \mathrm{Cf}$. Roger, 2002, p.35. Este conceito pode ser encontrado na obra Essais de critique et d' histoire (1858).

${ }^{5}$ Ver Carvalho, [18?] 2008, p.111-112. Esta autora considera que Taine, ao formular o seu determinismo na arte, havia utilizado e aperfeiçoado o princípio crítico de Sainte-Beuve. “A crítica de Sainte Beuve é uma criação! Na obra de arte vê a época em que ela surge e o homem que a produziu. A anedota elucidativa, o comentário sugestivo, o estudo minucioso do caráter do escritor, o meio em que ele se moveu, a influência direta ou indireta, que esse meio exerceu em todas as circunstâncias [...] O grande crítico da nossa raça neste século é com toda a certeza Sainte Beuve. Os que vieram depois dele deram a fórmula matemática, precisa da doutrina que ele praticara e descobrira com a ligeireza, uma elegância, um gosto nunca mais realizados. [...]. Taine, aceitando a herança de Sainte Beuve, foi além do que ele era, um naturalista que levou para os estudos de arte o seu forte método científico, que verifica, prova, experimenta e conclui depois”.

${ }^{6}$ Cf. Chagas, EC, [1866] s.d, p.198. A noção de genialidade está associada às categorias de imaginação e inspiração. A imaginação é “ [...] a que primeiro desperta, e a que subordina a si todas as outras”. Em relação a esta tendência crítica, os ensaios de Baudelaire sobre Edgar Alan Poe em Contos de Imaginação e mistério e Shakespeare, de Victor Hugo, podem ser bons exemplos. Mas Pinheiro Chagas, ao fazer a sua crítica, irá adotar os princípios tanto do método biográfico, de Sainte-Beuve, como os fundamentos da linha idealista como o faz nos artigos Antonio Gonçalves Dias e William Shakespeare, de Victor Hugo.
} 
vezes, críticos oitocentistas, como Luciano Cordeiro, faziam alusão a um julgamento isento de rancores, que tencionava aproximar-se de uma “ [...] cátedra à altura de Pope, ou Boileau, ou de Taine, ou de Ulrich, ou de Tiek, ou d'Arnaud, ou [...] a de Saint-Beuve [...]” (CORDEIRO, 1869, p.9-10). Mas se isso era um desejo, nem sempre ocorria, já que o estudo da crítica, em geral, mostra que ela decorria das relações pessoais daqueles que a escreviam.

E, de certo modo, com o surgimento de vários jornais e revistas, estas publicações de críticas avulsas se avolumaram, tornando possível ao escritor manter-se em evidência, ora detratando os desafetos ora bajulando os amigos.

O homem de letras, que invariavelmente estava ligado ao trabalho jornalístico por razões financeiras e de notoriedade, publicava não só fragmentos de suas obras como também suas críticas a outros livros. Ensaios críticos (1866), de Pinheiro Chagas, é uma prova disso, pois fora organizado com artigos publicados semanalmente nos periódicos da época. Geralmente, esses volumes eram precedidos de prefácios e de notas introdutórias ou finais, que hoje nos permitem entender o fazer literário e as relações literárias que se estabeleciam no circuito cultural daquele tempo.

Nas duas palavras de introdução do referido livro de Chagas, por exemplo, seu autor não consegue esconder as mágoas advindas de suas contendas com os adversários, e afirma que os seus juízos estariam isentos de “[...] mesquinhas paixões, [...] invejas, [...] ódios e [...] rivalidades [...]” (CHAGAS, [1866] s.d, p. 3). Ao final do livro, o crítico retoma novamente a questão, e justifica as censuras que fez às obras Teófilo Braga e de Vieira de Castro. Pela reunião de textos que faz, recuperando o ensaio negativo sobre Teófilo Braga e outro de louvor à produção literária de Antonio Feliciano de Castilho, e pelas duas advertências que abrem e encerram o volume, pode-se concluir que ainda estava viva a declaração de guerra entre os intelectuais da escola lisboeta e os de Coimbra. Os primeiros com a clara intenção de permanecerem na liderança do campo cultural e, de outro lado, os que desejavam destituir Castilho do cargo de mandarim.

Na verdade, o que estava em jogo para ambos os lados é aquilo que Pierre Bourdieu (1996) considera como monopólio da legitimidade literária, quer dizer, o estabelecimento de quem é escritor e quem tem autoridade para designá-lo como tal. Assim, quem estava no comando determinava quais os critérios estéticos que iriam definir o perfil de escritor.

Decidir no papel e de maneira mais ou menos arbitrária acerca de debates que o não são na realidade, como a questão de saber se este ou aquele pretendente ao título de escritor (etc.) faz parte da população dos escritores, é esquecer que o campo de produção cultural é um terreno de lutas, através 
da imposição da definição dominante do escritor, visam delimitar a população daqueles que têm o direito de participar na luta pela definição do escritor. (BOURDIEU, 1996, p.256-257).

Associando o contexto histórico-literário em Portugal descrito com o estabelecido pelo filósofo francês, subentende-se que ambos os lados em suas oposições literárias e ideológicas lutavam para evidenciar uma definição de escritor e, por conseguinte, obter o gerenciamento do meio cultural e conquistar novos adeptos a suas concepções literárias.

Nesse sentido, antes de iniciarmos a apresentação diacrônica da imagem de Pinheiro Chagas, esclarecemos que a mesma será feita à luz daquilo que Bourdieu (1996) considerou como a obra de arte como fetiche. Isto quer dizer, a validade desta não é o seu criador que a determina, mas um grupo dotado de competências estéticas, atuais detentores do monopólio do modo de produção cultural, que conhecem e reconhecem o seu mérito. Logo,

Cada campo produz a sua forma específica de ilussio, no sentido de investimento no jogo que arranca os agentes à indiferença e os inclina e dispõe a operarem as distinções pertinentes do ponto de vista da lógica do campo, a distinguirem o que é importante ( $<$ o que me importa $>$, interest, por oposição ao que me é <igual>, in-diferente). (BOURDIEU, 1996, p.260, grifo do autor).

Assim, objetivando conhecer como se comportaram o discurso da crítica literária no que tange à obra e imagem de Pinheiro Chagas, iniciaremos com os textos publicados de seu tempo $^{7}$. Num segundo momento, apresentaremos os que se referem ao século $\mathrm{XX}$, para, depois salientarmos o pensamento crítico da contemporaneidade sobre esse autor.

Optamos, inicialmente, por organizar a crítica oitocentista em blocos temáticos, em que, na primeira parte, expõem-se os pareceres, alguns com pequenas restrições ao estilo do nosso autor. No seguinte, agrupamos as críticas detratoras. Para ao final dessa seleção crítica de oitocentos, apresentar textos em que há uma ausência completa de seu nome e de suas obras, mesmo em se tratando de assuntos ligados ao romance histórico e ao teatro, gêneros que foram privilegiados por Pinheiro Chagas.

Há uma razão clara de começarmos este inventário crítico pelos textos de Antonio Feliciano de Castilho. Primeiramente, baseados no censo comum de ser Pinheiro Chagas defensor e sucessor direto dos padrões literários daquele. E também por ter sido a Crítica

\footnotetext{
${ }^{7}$ Dos textos pesquisados, foram excluídos deste universo as homenagens póstumas, por serem feitos sob muita comoção, aspectos que poderiam interferir na imagem real construída de Pinheiro Chagas.
} 
literária $^{8}$, de Castilho, paratexto da obra inaugural de Chagas, um instrumento de ataque aos jovens de Coimbra 9 .

[...] hoje o seu nome é já dos primeiros, a sua fama das mais extensas, os seus escritos dos mais festejados e relidos, e a sua fecundidade das com mais razão celebradas.

Eis aqui, portanto, em meu entender, o homem que hoje preencheria, honrando-a, a cadeira de literatura moderna.

Nenhum dos dotes desejáveis lhe falece: conhecimentos já copiosos, anciã de os adquirir novos, juízo claro e de relance, gosto seguro, voz insinuativa, linguagem fluente e uma daquelas descomunais memórias, ao mesmo tempo de cera para receber e de mármore para conservar; memória que maravilha a quantos a presenciam (CASTILHO, [1865] 1901, p.176).

Depois disso, o Poema da mocidade imortalizou-se de forma negativa, apenas como instrumento de desavença para o desencadear da Questão Coimbrã. Mário Monteiro (1943) considera que esta obra demarca duplamente o início da vida literária de Pinheiro Chagas e o fantasma constante de sua mediocridade literária “[...] por ter servido, por vontade de Castilho, para provocar a discórdia entre os intelectuais andando, talvez, à mistura das ambições políticas de alguns e dos ideais alevantados e nobres que os outros sempre haviam defendido" (MONTEIRO, 1943, p.59).

Já comentamos em nosso texto de mestrado que, embora naquela época seu autor tivesse somente 23 anos, já angariava uma respeitabilidade por alguns de seus artigos literários e políticos. Prestígio este que se esfumaçou nas histórias literárias posteriores, devido ao embate de 1865-66, pois o mesmo foi decisivo na consolidação da imagem de um crítico intransigente e conservador.

Para Alberto Ferreira (1966), ao participar de todas as polêmicas direcionadas a Castilho - na contenda de D. Jaime, na Questão Coimbrã e na Faustina, sempre se colocando como primeiro debatedor - passou a ser inevitável que o nome de Pinheiro Chagas ficasse associado

\footnotetext{
${ }^{8}$ Apresentamos de maneira sucinta os principais fundamentos discutidos por Castilho em sua "Crítica Literária". A restrita análise de forma e fundo do poema só se dá ao final da carta-posfácio, apontando como defeito a metrificação. Inicia-se com um panorama da literatura de 1865, citando elogiosamente Camilo Castelo Branco, Mendes Leal, Tomás Ribeiro. Aproveita o ensejo para apresentar a figura talentosa de Pinheiro Chagas e de recomendá-lo a cadeira de literatura do curso superior de letras, além de condenar um tipo de literatura que surgia. Para estas, faz referência a dois mancebos de Coimbra, Teófilo Braga e Antero de Quental, amenizando o ataque cita Vieira de Castro. Dos primeiros, condena a poesia nebulosa e metafísica, incitando, por assim dizer, o manifesto de Antero de Quental, Bom senso e bom gosto.

${ }^{9}$ Ver Castilho In.: Chagas, [1865] 1901, p.166 Antes de fazer a recomendação de Pinheiro Chagas a terceira cadeira do Curso Superior de Letras, Castilho desabona a qualidade estética da nova geração. " Corromper-se porém em tanta maneira uma literatura que nunca chegara deveras a amadurecer grande enigma, grande confusão, e grande lástima! [...] Os espíritos novéis e boçais, capazes de doutrina, mas sem doutrina, nem paciência para granjearem. [...]”.
} 
a ser o defensor e o sucessor direto dos seus padrões literários. Adicionada a esta ideia de crítico oportunista, também foi decisivo ter retificado suas avaliações ao poema Visão dos tempos, de Teófilo Braga, depois das censuras de Castilho.

Tanto no texto anteriormente citado de Castilho como em Telas literárias ([1872] 1907), que iremos agora destacar, há um propósito claro de indicar o amigo e discípulo a algum cargo. No primeiro já exposto, de repercussão negativa e tumultuada, tinha como indicação o cargo de professor do curso superior de Letras, já o outro, a recomendação se destinava para a função de sócio efetivo da Academia Real das Ciências.

Com este conjunto de dotes de espírito e de coração, com esta paixão de estudo, e esta mocidade tão prometedora ainda, quanto não há para esperar de glória para um tal nome, e de serviços momentosos para as nossas letras! Eis aqui o que unicamente me instigou a propor a classe de literatura desta nossa academia o sócio correspondente Manuel Pinheiro Chagas para o lugar de sócio efetivo. (CASTILHO, [1872] 1907, p.25, grifo nosso).

Embora faça uma explícita recomendação do pupilo à academia neste texto, novamente tratase de uma análise superficial do conjunto da obra de Pinheiro Chagas. Nela, podem ser conhecidos alguns títulos de Chagas publicados relacionados à História, - como romances históricos e compêndios -, ao teatro, à crítica literária e aos dois ensaios que fez para os concursos do Curso Superior de Letras. Apesar disso, parece-nos, diante do exposto, que todas as críticas dispensadas a Chagas pressupunham um desejo velado de Castilho em proteger os diversos setores instrucionais e literários das concepções dos dissidentes de Coimbra que poderiam influenciar no gosto da época ${ }^{10}$.

Diferentemente do ensaio de Castilho, que não relaciona todos os títulos publicados por Chagas, os estudos de Inocêncio Francisco da Silva ${ }^{11}$, já pela catalogação que faz da obra desse autor, passa a ser referência para as histórias literárias posteriores. A sua maneira clara e didática de disponibilizar os títulos por data de publicação possibilita ao leitor não só conhecer os diversos gêneros em que Chagas escreveu como identificar se estes escritos foram publicados inicialmente em folhetim.

\footnotetext{
${ }^{10}$ Ver Hess, 1978. Este autor considera que, nesse tempo, estabeleceu-se um círculo vicioso, o escritor, dependente do público, escrevia o que mais agradava a este. Por outro lado, a falta de inovação, que imperava no campo literário, não permitia que o leitor tivesse acesso a novas tendências estéticas. Assim, a literatura, na sua concepção, permanecia estagnada.

${ }^{11}$ Ver Aranha, 1893, p. 288-297. Este trabalho foi continuado por Brito Aranha, sendo uma das fontes citadas em textos como A grande enciclopédia portuguesa (1945) e o de Joel Serrão (1992).
} 
Indicado o estudo mais completo no que se refere ao espólio literário de Pinheiro Chagas, apresentaremos agora outros textos de menor alcance desse mesmo período, mas não menos importantes para o propósito deste estudo.

A primeira conclusão a que se chega depois de debruçarmos sobre as considerações de Visconde Benalcanfor (1874), Gervásio Lobato (1881), Candido Figueiredo (1881) e Maria Amália Vaz de Carvalho (1906), é de uma unanimidade entre estes intelectuais em caracterizar o autor do Poema da Mocidade como uma poderosa individualidade literária. Este conceito muito se deve a sua escrita multiforme que, nos quatro pareceres, entendiam ser de estilo rápido, claro e fluente. Gervásio Lobato (1881) chega a denominá-lo por este motivo como "não só uma celebridade de Portugal, mas sim um punhado de celebridades" (LOBATO, 1881, p.281). Tanto este autor como Candido Figueiredo fazem referência à História de Portugal de Chagas como uma obra importante para a historiografia portuguesa, pela extensão de seus estudos sobre o passado nacional ${ }^{12}$.

Depois de ter conquistado o primeiro lugar no teatro e no folhetim político, depois de se ter colocado entre os nossos melhores romancistas, Pinheiro Chagas tomou o seu lugar entre os mais notáveis historiadores portugueses, com os seus oito volumes da História de Portugal, obra de vulto e de valor notável, que teve grande sucesso e de que se está fazendo agora uma nova edição (LOBATO, 1881, p. 283).

Não só os livros de História, mas também a sua produção volumosa de artigos, principalmente os políticos, receberam considerações elogiosas de João Chagas (1906) e Maria Amália Vaz de Carvalho ([188?]1906). Nos textos destes estudiosos, os ensaios de Pinheiro Chagas são considerados como admiráveis, pontuados de criticidade, de lucidez e de humor. Veja-se, a título de exemplo, este fragmento do texto de Carvalho. “ O artigo escrito sobre $O$ joelho, acerca do caso da véspera, quase sempre político ou parlamentar, era dos que ficam lembrados por muito tempo a quem os lera entre frouxos de riso" (CARVALHO, [188?] 1906, p. 131).

Mesmo assim, para João Chagas, Maria Vaz de Carvalho e Candido de Figueiredo, a mácula da vida literária de Chagas estaria no fato de ele ter escrito não só a tão celebrada peça teatral, A morgadinha Valflor, considerada melodramática, como também o Poema da Mocidade, sob os moldes de Castilho.

\footnotetext{
${ }^{12}$ Ver Matos, 1998, p.37. Posterior aos anos de 1860, dois jovens aparecem no cenário cultural com propostas distintas na produção da História de Portugal. Fazendo oposição a história de Oliveira Martins, a de Pinheiro Chagas teve grande sucesso e durante muito tempo foi referência no ensino de história nos liceus.
} 
O seu Poema da mocidade é um livro de rapaz, tem frouxo o enredo e a narração monótona, mas é a obra de um poeta e de um versificador correto, como de quem escrevia sob os olhos do primeiro mestre em versificação portuguesa [alusão a Castilho] (FIGUEIREDO, 1881, p.79).

Nesse tempo ainda escrever bem era um título; e de poetas e escritores se compunha o estado maior da Regeneração comandado por Fontes, que lia pouco, mas que apreciava o talento sob que forma fosse. Encontrava-se então de lira em punho nas secretarias de Estado e no Parlamento. A prova de concurso para bom ministro era ter feito um bom poema ou uma comédia aplaudida. Pinheiro Chagas tinha feito dezenas de obras literárias, estava, pois indicado para político (CARVALHO, 1906, p.128).

Geralmente, as histórias literárias - que detratam a figura de Pinheiro Chagas devido ao sentimentalismo exagerado presente em sua obra e sobre suas relações com o Estado, recuperam o texto de Vaz de Carvalho - entre outros as de Luiz Francisco Rebello (1968) e de Álvaro Manuel Machado (1996).

Essa ideia convencionalizada de escritor melodramático é que faz com que Silva Pinto (1878), por exemplo, reconheça apenas os trabalhos de Chagas no campo historiográfico e crítico, apesar de nesta época, alguns de seus romances históricos já terem prestígio junto ao público como as diversas apresentações d’ A morgadinha de Valflor. Já Luciano Cordeiro $(1869)^{13}$ e Sampaio Bruno ([1885] 1984), mais inclinados aos ideais da Geração de 70, desqualificam toda a sua produção literária por meio de julgamentos duros, depreciativos e excludentes. Cordeiro, em seu Livro de crítica. Arte e literatura portuguesa de hoje, prefigura-o como medíocre, tanto como romancista, poeta ou crítico. Ainda segundo este estudo, a permanência de Chagas no circuito das letras devia-se em grande parte a ele ter associado política com literatura, e que seus escritos sob variados gêneros seriam a expressão da sua falta de genialidade e especialidade artística.

Sampaio Bruno segue a mesma linha de raciocínio de Luciano Cordeiro quanto ao oportunismo literário de Chagas. Se por um lado, o livro daquele configura-se numa defesa clara ao realismo, de outro, as considerações que faz à obra de Pinheiro Chagas, na seção Romance histórico, não deixam de revelar as suas antipatias por este escritor. Nessa época, dos dez romances históricos publicados de Chagas, somente dois são citados, Os guerrilheiros da morte (1872) e As duas flores de sangue (1875). Ainda que a abertura do parágrafo pareça encaminhar-se para um elogio: "nesta confusão de produções inoportunas

\footnotetext{
${ }^{13}$ No seu segundo livro de Crítica, apesar de Luciano Cordeiro escrever na advertência que tencionava retificar avaliações e responder às apreciações e objeções feitas ao seu primeiro livro, não há nenhuma referência a retratações dirigidas a Pinheiro Chagas, confirmando, assim, as suas posições anteriores quanto à literatura desse autor.
} 
não há mais a separar do que, pelo encanto duma forma impressiva, as novelas do Sr. Pinheiro Chagas' (IDEM, p.25, grifo nosso), ele acaba tacitamente desqualificando As duas flores de sangue ao sugerir uma falta de originalidade, uma vez que “ a figura de Leonor da Fonseca Pimentel, em cuja poética existência já em San Felice, [de] Alexandre Dumas, buscava efeitos prestigiosos” (IDEM, p.25, grifo nosso). E conclui que essas obras de Chagas eram uma tentativa do literato em “[...] cooperar na obra revolucionária em que ia entrando o pensamento português [...]” (IDEM, p.25). Esta última consideração não deixa de ser compreendida como um engodo, quando a associamos aos outros comentários feitos linhas anteriores do mesmo texto.

[...] [o] progressivo definhamento da fórmula da novela histórica, que principia num intuito de iniciação política [...] visivelmente vai degenerando numa simples fantasiação, destinada a entreter os ócios dos leitores, sem outro objetivo mais do que o de maravilhar pela compilação do entrecho e pelo prestígio do estilo (IDEM, p.23, grifo nosso).

Depois de ter lido as considerações dirigidas à obra de Chagas, o leitor não se surpreende com a finalização dada ao capítulo, de que toda a decadência, pela qual passava as letras tinha sido graças à “ [...] audácia inovante [que] se sumiu numa transação com o tradicionalismo clássico, assinando-lhe o protocolo o Visconde de Castilho”. (IDEM, p.28).

Por fim, as conclusões a que se chega são de que Chagas é um oportunista literário pretensamente revolucionário. Lembrando que esta não seria a única vez que Bruno se refere a Chagas nesses termos. Na sua obra, Os modernos publicistas portugueses (1906), Sampaio Bruno assinala a postura reacionária, falsamente liberal e retrógrada desse autor acerca do seu estudo sobre a Comuna de Paris. Bruno censura não só o imediatismo de publicação, mas também a má elaboração do texto, que expõe uma retórica militarista enfática, não conseguindo ocultar o chauvinismo do autor.

Sob qualquer pretexto ou texto, Sampaio Bruno parece querer ressaltar a crítica superficial e precipitada de Pinheiro Chagas. No capítulo denominado conto satírico, Bruno, ao avaliar a Comédia de Lisboa, de Gervásio Lobato, deixa esta no segundo plano da discussão, passando a se ocupar de rebater as considerações que Chagas fez ao realismo no prefácio desta obra. Depois das várias refutações de Sampaio Bruno aos argumentos de Chagas sobre a estética realista, aquele termina de forma irônica colocando-o como herdeiro do estilo ultrapassado de Castilho. 
O sr. Pinheiro Chagas acha depois também que os processos de estilo dos modernos escritores se prestam demasiadamente ao clichê e não repara nas imitações, com que todos os rabiscadores de Almanaque conseguiram aproximar-se dos modelos fornecidos pelos velhos mestres acadêmicos [alusão a Castilho](IDEM, p. 92, grifo nosso).

Além dessas histórias literárias que citamos, adquire grande importância a análise que Teófilo Braga fez sobre Pinheiro Chagas. Embora alguns considerem a sua crítica tendenciosa e de escrita desleixada ${ }^{14}$, suas ideias sobre esse escritor serão recuperadas por parte significativa dos trabalhos publicados no século XX. Por duas razões não podemos excluir os seus textos. Primeiro, pela associação que faz entre a estética ultrarromântica e a aquisição de cargos governamentais. E segundo, pela ausência do nome de Chagas no estudo de alguns gêneros, como o teatro, que ele já dava mostras de grande popularidade. Possivelmente, a exclusão de referências diretas a Chagas ou à sua obra seja uma represália de Teófilo Braga ${ }^{15}$, que considerou a mesma atitude de seu desafeto aos seus trabalhos.

Nunca tive relações com este polígrafo lisbonense; soube que me elogiou em três folhetins, que conspurcou por algum tempo o meu trabalho, que procurou fazer-me passar por nebuloso, simbólico e mítico, que me caracterizou como refusé da literatura e que se calou afinal, quando se estabeleceu contra mim a conspiração do silêncio ( BRAGA, 1872, p.41).

Talvez, isso justifique que, das críticas literárias de Braga que tivemos acesso, a única referência encontrada é sobre o Poema da mocidade (1865), apenas como exemplificação da crítica protecionista de Castilho. Na sua concepção, esse tipo de obra estava a serviço de todo autor que desejava ter acesso às funções públicas.

A atividade jornalística e literária serviam em Rebello da Silva para realizar uma aspiração política, um sonho comum a todas as naturezas medíocres, mas hábeis - o ser ministro. Mendes Leal, que não possuía a eloquência

\footnotetext{
${ }^{14}$ Ver Coelho, 1969, p.119-120. Segundo este crítico, “[...] nunca se eximiu ao biografismo, inquinou de facciosismo político e até de simpatias ou antipatias os seus juízos literários, nunca deixou de estruturar e escrever mal, com excessiva pressa, desleixadamente".

${ }^{15}$ Ver Ortigão, [1871] 1948, p. 152. Este autor também confessadamente diz fazer uso dessa nova estratégia de não fazer referência às produções literárias dos adversários. "Atualmente estão um tanto demudados os usos literários. Já ninguém se insulta. Aparecendo um livro de mérito há um processo mais cômodo que o de dilacerar o autor: é não escrever uma palavra a respeito dele. Chama-se isso a conspiração do silêncio. Além de ser muito menos perigoso que o antigo elogio mútuo, o atual processo apresenta uma outra vantagem: é muito mais infame [...] Há escritores predestinados à loa e outros predestinados ao silêncio. Pinheiro Chagas pertence ao número dos segundos. [...] Dos livros condenados nem uma só palavra, a não serem as do anúncio que o editor mandou pagar!”.
} 
correta e acadêmica como ele, já tinha sido uma vez ministro (BRAGA, 1892, p.167).

Nesse fragmento, apesar de Pinheiro Chagas não ter sido oficialmente citado como integrante dessa escola, como aparecem os nomes de Rebello da Silva e Mendes Leal ${ }^{16}$, é sabido que, para a Geração de 70, ele era o maior beneficiário das proteções de Castilho.

Assim, partilham dessa opinião tanto Teófilo Braga como Oliveira Martins. Este último, em Portugal Contemporâneo, é mais explícito e cita Pinheiro Chagas como um dos últimos ultrarromânticos a conseguir, junto com Tomás Ribeiro, um cargo de ministro. De acordo com este historiador, Castilho era um velho Fontes ${ }^{17}$ da poesia.

O chefe deste neo-romantismo, entre burocrático e piegas, artificial, sem raízes no coração de uma gente prosaica ou devassa; o chefe desse romantismo cujos derradeiros foram Chagas e Tomáz Ribeiro, com o $D$. Jaime e a secretaria da Marinha, com a Morgadinha e uma política sempre infeliz; o chefe de uma escola arrebicada e petulante, foi Castilho- um velho Fontes da poesia. [...] e um governo literário de um homem vazio de idéias, repleto de poética sábia. (MARTINS, [1881] 1981, p. 363).

Diante da última crítica apresentada do período oitocentista, são evidentes os pontos de contato entre essas últimas e as histórias literárias do século XX, como as de Eugênio Lisboa, ao afirmarem que "Hoje pode dizer-se, sem grande injustiça, que o nome de Pinheiro Chagas só sobrevive pela aura reflexa que lhe deu a polêmica arrastada, de que foi origem, com os da geração de 70”(LISBOA, s.d, p.240).

Esta frase de Eugênio Lisboa sintetiza expressiva parte do pensamento crítico que orientou as referências sobre Pinheiro Chagas no século XX. Contudo, nem sempre foi assim. No início de novecentos, há uma mudança de perspectiva, e Chagas começa a ser visto não pelo prisma biográfico - das relações tumultuadas que manteve com os seus contemporâneos - mas pelo conjunto de sua obra. A partir de então, veremos que até finais dos anos 30, a

\footnotetext{
${ }^{16}$ Ver Braga, 1892, p. 3. Apesar de este autor não citar o nome de Andrade Corvo nesse fragmento. Ele o incluí numa referência anterior “ [...] Rebello da Silva, Mendes Leal, e Andrade Corvo e outros foram representantes inconscientes saídos da anarquia mental do jornalismo para a anarquia política do constitucionalismo”.

${ }^{17}$ Ver Chagas, VBA, [1873] s.d, p.191-197. Antonio Maria de Fontes Pereira de Melo (1819-1887), conhecido como o fundador das obras públicas e pelo braço de ferro com que as empreendeu, pois teve de enfrentar não só o negativismo da oposição como os de alguns de seus aliados. Ele foi o mais importante político da Regeneração. Sua proposta consistia no estabelecimento de várias medidas para recuperar o atraso de Portugal em relação a outros países da Europa. O projeto de inovação, que ficou conhecido como fontismo, promovia o aumento do número de estradas, dos caminhos de ferro que ligavam Lisboa a outras partes de Portugal e da Europa e o funcionamento da primeira linha telegráfica. Pinheiro Chagas considera que “ [Fontes Pereira de Melo] dirigindo com mão firme, com rasgada iniciativa, e sem a mais leve hesitação, o governo do Estado, pára sempre no limite das atribuições que lhe concedem as leis”.
} 
crítica orienta-se pelo discurso de Antonio Feliciano de Castilho, quando sugere que a poligrafia e proficuidade de Chagas estaria relacionada às necessidades pecuniárias. Consideramos que a linha deste pensamento crítico originou-se no seguinte trecho da Crítica literária de Castilho feita ao Poema da Mocidade.

Representem-se Pinheiro Chagas passando as noites em claro entre o leito de sua mulher e o berço de seu filho, que ambos dormem, espertando de hora a hora a luz de dentro como a da lâmpada que lhe supre o dia, e recebendo do silencio a inspiração para os artigos, que de toda a parte, e a porfia, se lhe pedem: aqui um romance, ali uma notícia, já um juízo literário, já uma polêmica, ora uma cena de lágrimas, ora uma exortação social, uma narrativa histórica, uma facécia, um desenfado, ou um alívio. E tudo isto promiscuamente, necessariamente, fatalmente, porque é o foreiro de vinte prelos, que lhes não dão respiro, porque também em roda de cada um deles os assinantes não cessam de exigir cotidianamente este almoço apetitoso a que o seu escritor predileto os avezou (CASTILHO, [1865] apud CHAGAS, [1865] 1901, p.181).

Excetuando Mendes dos Remédios ${ }^{18}$ (1930) que, além de ter reconhecidos estudos, sugere a revisitação ao conjunto das obras de Chagas, as demais citações deste período seguem a linha do viver da pena, e são de autores pouco renomados, como Pedro Júlio Barbuda, (1918), J. Barbosa de Bitencourt (1923) José Agostinho (1927) e Simões Dias (1929). Há nestes estudos leves tons de enaltecimentos, apesar de indicarem que a qualidade subordinou-se à quantidade. Um desses exemplos seria a crítica de Agostinho, que, de forma tímida, considera que a perda de qualidade estética estaria relacionada a todo tipo de adversidades a que esteve exposto.

Será, portanto, nessa linha de ser dono de uma produção que visava somente ao lucro que Simões Dias justifica o ostracismo de Pinheiro Chagas.

Pinheiro Chagas é um polígrafo que poderia ter deixado algum trabalho monumental, se a política por um lado e as necessidades da vida real por outro lhe tivessem deixado liberdade e ócios para se dedicar exclusivamente ao cultivo das letras. O talento despendeu-o dia-a-dia, a compor costumes, folhetins, correspondências para jornais, compêndios para escolas, traduções para empresas literárias, memórias históricas, elogios acadêmicos, discursos parlamentares, etc. Em todos estes trabalhos feitos à pressa, Pinheiro Chagas pode imprimir o cunho de sua individualidade [...] (DIAS, 1929, p. 271).

\footnotetext{
${ }^{18}$ Ver Remédios, 1930, p.503. O crítico faz recomendações de revisitação da crítica e do público às obras de Pinheiro Chagas, que poderiam ser incentivadas por meio de republicação do conjunto de seus romances.
} 
Mas também não desconsidera o efeito negativo sobre sua obra das relações políticas que manteve com a situação.

Depois de organizado esse primeiro bloco de crítica, vale ressaltar que, mesmo diante de críticas positivas, nenhuma delas faz uma apresentação do espólio literário de Chagas, que é numeroso. Quando muito, há apenas o destaque do título do teatro A morgadinha de Val Flor $^{19}$.

Iniciando os comentários sobre as histórias literárias e textos críticos dos anos quarenta, década em que muitos da Geração de 70 completaram o centenário de seu nascimento, o que se viu foi uma volumosa produção de livros e estudos sobre Eça e Antero. E pouco se escreveu sobre Pinheiro Chagas - que teve uma ou outra homenagem - reforçando a ideia de que as histórias literárias posteriores ao século XIX centralizam-se sob a ótica dos novos, traçando definitivamente uma vereda crítica, em que a historiografia parece não mais deixar.

Parece ter havido uma unidade crítica entre os estudiosos dos anos 40 que, ao exaltarem as qualidades ecianas, rebaixam na mesma medida as dos seus desafetos. Assim sendo, é de se esperar que Chagas figure hoje na historiografia em apenas três situações: sendo o pivô da célebre polêmica literária $A$ Questão Coimbrã, como aliado importante de Castilho na Questão Faustina e antagonista das escolhas literárias do autor de O Crime do Padre Amaro.

Em estudos de biógrafos de Eça de Queirós, como os de Vianna Moog (1938), Álvaro Lins (1939) e João Gaspar Simões (s.d), estes vão mais longe e apresentam a concepção de que Chagas considerava as ideias revolucionárias ecianas como verdadeiras depreciações à imagem de Portugal. Álvaro Lins, que dialoga com Moog, apresenta a seguinte assertiva às causas do rebaixamento de Chagas: “Tornou-se impossível pensar em Pinheiro Chagas sem associar o seu nome à ideia do ridículo” (LINS, 1939, p. 134). Numa transcrição quase literal de Vianna Moog, João Gaspar Simões acha justo o modo apequenado com que veem a figura literária de Chagas, por suas tentativas de desqualificar os escritores da nova estética.

[...] o parecer do júri que exclui A relíquia do prêmio é assinado por M. P. Chagas, impertinente adversário do realismo em geral e de Eça em particular. (Por isso mesmo este, a partir de certa altura, lhe chamará 'Brigadeiro' - o 'brigadeiro Chagas' ou o 'homem fatal' - fatal no seu destino de escritor.) (SIMÕES, s.d, p.129).

\footnotetext{
${ }^{19}$ Esta peça foi adaptada para o cinema por Ernesto de Albuquerque (1883-1940) em 1923 e estreada por: Maria Pia d'Almeida, Ausenda de Oliveira, Maria Sampaio, Artur Duarte, Duarte Silva e Mário Santos.
} 
Muito dessa depreciação teve sua origem na contenda Brasil e Portugal (1880) digladiada entre Eça e Chagas, que, para alguns críticos como Viana Moog (1938), Alberto Ferreira (1966-70) e Gaspar Simões (s.d), foi a execução sumária em público do brigadeiro Chagas. De certa forma, fica evidente que, para estes estudos, será Pinheiro Chagas o instigador das várias disputas, com o intuito de ridicularizar Eça, o que na prática se inverteu. Por sua vez, o texto de Fidelino de Figueiredo, em consonância com as ideias dessa última linha crítica apresentada, dispensa os seguintes comentários a Chagas: "Pinheiro Chagas considerava as liberdades críticas de Eça como delitos contra os deveres patrióticos e foi um constante adversário da nova literatura” (FIGUEIREDO, s.d, p.301). Nessa base, o nome do autor de $O$ poema da mocidade só ocupa espaço como detrator da estética e ideologia da Geração de 70 ou de Eça de Queirós.

Para não tornar mais enfadonha esta exposição, optamos por apenas citar a partir de agora o nome daqueles que se filiaram às ideias da Geração de 70, e viram o nome de Pinheiro Chagas apenas como antagonista desses revolucionários: João Gaspar Simões (s.d), Antonio Ramos de Almeida (1947), Alberto Ferreira (1966), Luiz Francisco Rebello (1968), João Medina (1974; 2001) e Campos Matos (1988).

A importância dos estudos de Ramos Almeida (1947), por exemplo, dar-se-á tanto pelo período em que é produzida, próxima aos centenários de nascimento de Antero e Eça, como pelo diálogo que estabelece com as histórias literárias de Fidelino Figueiredo ${ }^{20}$ e as de Teófilo Braga.

A figura literária de Manuel Pinheiro Chagas surge-nos hoje deploravelmente diminuída e por mais boa vontade que se tenha ninguém com seriedade a poderia redimir. Ele próprio traçou o seu destino: trocou a dignidade de uma carreira literária pela glória fácil, pela fama passageira, que os dirigentes lhe ofereceram para subornar o seu talento de escritor. Escrevia bem, num estilo vigoroso e dinâmico, procurava estar a par da cultura do seu tempo. Procurava realizar menos mal os gêneros literários que tentava, mas tudo isso é muito pouco para fazer dele uma figura de projeção. Ficou, sobretudo, na História da nossa literatura como chefe de fila contra a Geração de 70, como leader da reação contra a plêiade notável de Homens progressivos que fizeram o extraordinário brilhantismo do nosso século XIX. Ele próprio se amarrou para sempre ao pelourinho e agora é tarde demais para o tirarmos de lá (ALMEIDA, 1947, p. 583, grifo nosso).

\footnotetext{
${ }^{20}$ Ver Almeida, 1947, p. 573. Assim, comenta o autor “ [...] Fidelino Figueiredo na sua História Literária justifica a sua enorme popularidade no teatro, no romance, na historiografia, na tribuna parlamentar em conjunto com outro gênio daqueles tempos. " Para esses êxitos serôdios contribuíram decerto as proeminências sociais que Ribeiro e Chagas atingiram, ”.
} 
A leitura deste último texto foi fundamental porque nos mostra a dinâmica que move toda a crítica daquele período, em cristalizar a imagem de Pinheiro Chagas num militante retrógrado tanto nas ordens literárias como políticas.

Desenovelando ainda mais os fios dessas histórias, chegamos aos anos 60-70, com os estudos de Almeida (1947) ${ }^{21}$ sendo, de alguma forma, retomados por outras críticas, como os estudos de Luís Francisco Rebello. Em sua antologia acerca dos cento e vinte anos de teatro português, seu autor faz o seguinte comentário:

[...] todos estes autores, condenados hoje ao justo esquecimento dos arquivos, permaneceram fiéis, ao longo da sua pálida obra, ao receituário do melodrama histórico. [...] A morgadinha de Valflor ficaria como a mais significativa de todo o nosso teatro ultrarromântico. (REBELLO, 1968, p.25, grifo nosso).

Diante do mencionado, entendemos que Rebello, e mais à frente de seu texto ele vai nos informar isso, só dará um lugar a Pinheiro Chagas em sua história do teatro, devido ao curioso e contraditório sucesso desse drama em tempos em que o Realismo já havia se consolidado. Este autor justifica que não é a sua proposta analisar detidamente o drama, mas informar ao leitor que, apesar de Chagas ter tido talento, ele desperdiçou-o com o ultrarromantismo.

[...] Quando, porém, o ultrarromantismo parecia já liquidado, pelo esgotamento dos seus temas e pela repetição mecânica das suas situações, e apenas sobrevivia melancolicamente numa ou outra peça dos que o haviam trazido, [...] eis que surge um jovem dramaturgo de vinte e sete anos a darlhe um novo e inesperado (mas passageiro) alento. [...] [Pinheiro Chagas fazia parte de] uma literatura oficial, anêmica e conservadora, que se imobilizara no tempo e perdera por completo o contato com a vida, ameaçada por uma escola que fazia do inconformismo a sua bandeira [Geração de 70]. [...] Pinheiro Chagas, o autor da Morgadinha, que assim uma vez mais se colocava ao lado das forças da reação e tomava o partido do antigo contra o novo (IDEM, p.33).

Além da história literária de Rebello (1968), outro texto importante é o Bom senso e bom gosto (Questão Coimbrã) de Alberto Ferreira (1966), não só pela criteriosa pesquisa que fez sobre esta polêmica, mas também pelo partidarismo que assume em relação à Geração de 70. Esta parcialidade pode ser notada por serem eximidos de qualquer excesso os discursos de

\footnotetext{
${ }^{21}$ Ver Rebello, 1968, p.71. Recupera as ideias de Antonio Ramos sobre o fato de hoje a imagem que se tem de Pinheiro Chagas é a caricatura desenhada por Eça de Queirós que é descrito como "verbalmente liberal, na realidade reacionário".
} 
Antero de Quental e de Teófilo Braga, mesmo o autor afirmando que, na querela, os debatedores não conseguiram manter a criticidade necessária que o embate exigia, pois muitas dessas peças tendiam a fazer de suas defesas meros ataques à imagem de seu oponente. Apesar da excelente recolha de fontes primárias da polêmica de 1865-66, e já explicitamos este aspecto, não podemos deixar de referir que se instaura neste texto uma recuperação literal dos discursos depreciativos que fez Teófilo Braga sobre o ultrarromantismo e os de Eça direcionados a Chagas de maneira zombeteira e caricatural. Um exemplo clássico disso é a primeira proposição defendida por Ferreira ao considerar que a contenda Brasil e Portugal fora o desfecho da Questão Coimbrã: “[...] será necessário esperar pachorramente pela saudável gargalhada de Eça, assistir, enfim, de alma lavada, à escalpelização crítica do patriotismo dos ‘brigadeiros vestidos à moderna' ”.(FERREIRA, 1966, p.106).

Embora fortemente marcado pela presença discursiva dos integrantes da Geração de 70, o estudo de Ferreira ainda trará à luz considerações do século XX. Destes, seu autor revitaliza uma discussão de Gaspar Simões sobre ter sido Pinheiro Chagas o verdadeiro protagonista da contenda de 1865, ainda que tenha sido Castilho o provocador.

[...] Castilho, cego e decrépito, era um fantoche nas mãos dos Chagas, dos Mendes Leais, dos Túlios, dos Patos e de toda essa camarilha contra quem Antero investira denodadamente. Eles decidiam o que Castilho deveria ou não deveria conhecer. Eis porque a eles cabe, em última análise, a responsabilidade de tudo o que aconteceu. (SIMÕES, [194?] s.d, p.42).

Ainda que essas histórias maculem a imagem de Pinheiro Chagas, apontando-o como opositor da Geração de 70, estudos como os de Sampaio Bruno e de Castelo Branco Chaves são mais eficazes em tentarem justificar o ostracismo de Chagas pela ausência de valor estético, quando muito sutilmente citam as relações tumultuadas do período. Chaves, num dos poucos trabalhos sobre $O$ romance histórico no romantismo português (1979), não dispensa muito espaço a Pinheiro Chagas, mesmo ele tendo publicado mais de quatorze títulos no gênero. Em uma frase apenas, Chaves o resume como “ [...] um folhetinista com motivos históricos ou pretensamente históricos, no geral preferiu ou o período da restauração de 1640 ou os finais do século XVIII ” (CHAVES, 1979, p.65). Até o final do capítulo, não ficam bem esclarecidos os porquês do rebaixamento dessas obras. Só mais à frente se conhecem as verdadeiras razões do crítico em relacionar essas produções à divulgação de um patriotismo retórico, que ajudava na promoção de seu autor a cargos políticos. 
Também não exerceu influência alguma sobre a evolução posterior do gênero romance [referência aos romances de Herculano, Garrett e Camilo]. O romance histórico, em que os primeiros românticos puseram tanta fé e tamanha esperança, deixou de si apenas o folhetim de pretexto histórico $e$ intuitos patrióticos ou meramente políticos. E foi, então, um gênero literário popular - mas como toda a literatura popular, para o ser, só o foi baixando de qualidade e de nível (IDEM, p.66, grifo nosso).

Nesse ponto, parecem aproximados o discurso de Castelo Branco Chaves com o de Teófilo Braga e, principalmente, com o de Sampaio Bruno, que tem recortes do seu texto apresentados em momentos em que se discute a degeneração do romance histórico.

Embora as críticas apresentadas, até esse ponto do nosso texto, confirmem o caráter folhetinesco dos romances históricos de Chagas, outros autores como Campos Matos reavaliam suas restrições e consideram que as histórias literárias têm injustamente “ [...] deformado e diminuído uma personalidade literária e humana mais rica e significativa do que imaginam aqueles que só conhecem dela a versão eciana” (MATOS, 2001, p.340). Reconhece, afinal, o valor de algumas recomendações de Chagas feitas a Eça, no período das duas polêmicas, que, de certa forma, este tentou efetivar.

Contudo, essa mudança significativa que ocorre nas avaliações de alguns críticos literários no século XXI acerca de Pinheiro Chagas, começa a ser vislumbrada desde os anos 80. Apesar de existirem muitas histórias literárias que continuam ainda reiterando as ideias que tinha a Geração de 70 sobre este autor ${ }^{22}$.

Assim, tencionamos, a partir de agora, dar relevo a outros textos que expressaram seu incômodo com o silenciamento de um escritor, dono de uma obra tão diversificada e numerosa. Como representantes dessa linha crítica, além da última citada, destacamos os juízos de Nuno Júdice (1985) e de Helena Carvalhão Buescu (1997). Mesmo fazendo um estudo superficial de alguns títulos de Chagas, esta estudiosa sugere uma releitura das obras desse escritor, justificadas, a princípio, por um tipo de composição de estrutura inusitada. Em A mantilha de Beatriz, por exemplo, o autor criativamente faz parecer que a história de uma de suas personagens inventadas teria servido de inspiração para Calderón escrever Antes que todo es mi Dama. ${ }^{23}$ Já $O$ segredo da Viscondessa, por sua estrutura, apresenta uma narrativa

\footnotetext{
${ }^{22}$ Ainda que haja a iniciativa de novos olhares sobre os romances de Chagas, principalmente os históricos, para nós, o pensamento crítico, a partir de então, divide-se numa linha mais favorável, mesmo em menor número, e outra mais alinhada ao discurso da Geração de 70. Em síntese, este último irá reafirmar as ideias de Teófilo Braga, Oliveira Martins, Ramalho Ortigão e Sampaio Bruno de que o ultrarromantismo era uma consequência do parlamento. Saraiva e Lopes (1996) e Carlos Reis (2001) podem ilustrar uma posição mais inflexível a uma revisitação às obras de Chagas.

${ }^{23}$ Ver Marinho, 2005, p. 109-120. Esta autora ressalta a criatividade ficcional de Chagas, ao se apropriar de um texto de Calderón como leitmotiv para um de seus romances históricos, constituindo “ [...] um interessante caso
} 
mesclada com a forma epistolar, possibilitando, com isso, a inserção num mesmo plano narrativo de vários discursos. A lenda da meia-noite, por outro lado, é aproximada à estrutura clássica do Decamerão, revelando-se numa técnica cuidada e intencional, com o objetivo de se criar uma

[...] sociedade em torno da qual se forma um tecido narrativo, cada um dos interlocutores comprometendo-se a, cada noite, contar uma história fantástica. De novo a estrutura é heterogênea e curiosa, jogando na multiplicidade dos níveis, entrechos e narradores (um deles é ... uma bolsa verde!) e na forma como as narrativas encaixadas contribuem para a evolução da ação principal (BUESCU, 1997, p.88).

Além dessa crítica favorável a três livros de Chagas, Nuno Júdice (1985) fez duas análises de seus contos. Para ele, o fato de este escritor estar à sombra se deve muito especialmente à concorrência injusta de uma produção intensa de Camilo e, de outro lado, pela obra realista de Eça de Queirós.

Mas Pinheiro Chagas tem contra si, para lá do fato de ter nascido a tempo de apanhar essa época sem história, e como se não bastasse pertencer ao grupo daqueles escritores como Rebelo da Silva, Júlio César Machado, Arnaldo Gama, Bulhão Pato, etc, etc, Irremediavelmente obscurecidos pelo duplo peso das sombras de Camilo e Eça - [além disso] tem contra si, dizia, uma imagem conservadora, tanto em política como em literatura (JÚDICE, 1985, Prefácio,s.p., grifo nosso).

Neste fragmento ainda, Júdice coloca em questão o caráter conservador dos escritos de Chagas. E defende, mais à frente desse mesmo texto, uma releitura de sua produção literária, principalmente dos seus contos.

Pinheiro Chagas é um escritor. E se sua linguagem tem, como é evidente, as marcas terríveis do período ultrarromântico, com uma adjetivação excessiva, exclamações redundantes, efeitos - e enfeites - mais cênicos do que literários, muita coisa se salva, nomeadamente no domínio do conto, que merecia uma releitura atual.[...].

[...] Chagas integra-se, com pleno direito a lá figurar, no gênero fantástico, dominando perfeitamente as suas regras: a indecisão entre o real e o sobrenatural que deixa o leitor na dúvida até o final, o suspense, e até um certo humor, visível na crítica ao noivado burguês, apesar do estigma misógino de que essa crítica possa estar imbuída. [...] A redação na primeira pessoa vai acentuar o tom subjetivo com que a aventura amorosa é

de legitimação do pastiche, jogando, simultaneamente, com a realidade da cópia e com a inversão de sentido, ao afirmar erradamente as relações de hipotexto e hipertexto”. 
vivida, levando o leitor a interrogar-se sobre o desfecho necrófilo não resultará antes de um excesso de imaginação provocado pela doença que, para o romântico, é sinônimo de paixão (JÚDICE, 1985, Prefácio,s.p.).

Concluindo, esperamos que tenha ficado claro que a inclusão ou permanência de muitos escritores do período oitocentista no cânone português é determinada pelas relações que mantiveram em seu tempo. É o que ocorre com Pinheiro Chagas, pois quase a totalidade da crítica pesquisada associa o valor de sua obra às suas decisões conservadoras e ao seu oportunismo nas letras. Consideramos ainda que a figura do crítico intransigente e polemista esteja interferindo na revisitação de seu espólio literário, pela maneira enfática que tinha de depreciar a nova estética que ganhava espaço.

Contudo, mesmo havendo críticos que o desconsideram enquanto escritor, ao ponto de não verem razões de uma releitura dos vários gêneros que ele publicou, começam a aparecer estudos que colocam em xeque esses juízos e sugerem uma análise mais cuidada de sua obra. Sob este prisma, nada é mais favorável aos propósitos desta pesquisa do que fechar esta seção com as palavras de Nuno Júdice quanto à qualidade estética de Chagas em Julieta.

Simples exemplo, entre outros possíveis, de uma construção que parece nada deixar ao acaso, revelando o domínio dessa técnica narrativa que é fruto, como referi acima, de uma atividade literária fecunda e que, pelo menos, conseguiu implantar uma tradição de leitura num público nacional que não é de menosprezar, tanto mais quanto é aqui visível a tentativa de adaptar à realidade portuguesa - para mais, citadina - o clima fantástico que a outras paisagens melhor se adapta do que à nossa (JÚDICE, 1985, Prefácio,s.p.). 


\section{II}

\section{PINHEIRO CHAGAS: HISTÓRIA E FICÇÃO}

Neste capítulo, depois de apresentadas algumas teorias que tentam definir um conceito sobre o romance histórico, é nossa intenção analisar a crítica de Pinheiro Chagas a outros romances, com o objetivo de conhecer a sua concepção do gênero. Discutiremos, ainda, as três fases de sua composição de romance histórico. Além disso, verificaremos com qual propósito este autor se utiliza dos elementos do gênero dramático. Feitos os devidos esclarecimentos à matéria aqui encontrada, passemos, então, à nossa discussão.

\subsection{Uma introdução ao romance histórico}

O fascínio pelo passado, sobretudo nacional, foi uma constante para o homem romântico. Com o Romantismo, a história, enquanto disciplina, ganha bases mais científicas com o propósito de elucidar períodos anteriores ${ }^{24}$. Dessa maneira, historicizar estava na alma da intelectualidade romântica, seja por meio de um rigor científico na recriação do passado medieval - como fez Alexandre Herculano, que viajou pelo interior de Portugal em busca de papéis que esclarecessem o viver nessa época - ou na criação romanesca de pretexto histórico.

Essa inquietude por uma identidade nacional, que se desenvolveu por todo o continente europeu após a revolução Francesa e as guerras napoleônicas, favoreceu o aparecimento do romance histórico entre fins do século XVIII e início do XIX, período em que Walter Scott lança seus romances. Além dos livros scottianos, foram ganhando espaço entre os leitores outras versões de mesmo gênero oriundas da França e Itália, como as de Alfred Vigny e Alexandre Manzoni.

No entanto, não é tarefa fácil a conceituação do gênero, devido à complexidade de sua construção que se utiliza tanto dos atributos da História como da ficção, campos que, desde Aristóteles, são apresentados como distintos, já que do historiador se espera que ele narre o acontecido, e do poeta aquilo que poderia acontecer. O filósofo grego reabilita a literatura, aproximando-a da filosofia, por tratar das verdades universais, nesse sentido, o seu caráter é superior em relação à História, porque esta se restringe ao particular.

\footnotetext{
${ }^{24}$ Cf. Guinsburg, 1978, pp.13-21. Foi na ideologia romântica que origina o princípio científico da História moderna, pois é nessa época que se efetiva o entendimento do indivíduo como ser histórico, na prática e no pensamento.
} 
Por outro lado, embora estes dois campos estejam em lados opostos quanto à verdade que veiculam, seguiram uma trajetória em parte comum. Nessa medida, por exemplo, importantes informações sobre o passado grego podem ser também conhecidas por meio dos versos de Homero. O mesmo ocorre com a cultura romana que atravessa a poética de Virgílio, como em Eneida. Da mesma forma, os relatos cronísticos dos achamentos do continente americano podem ser vistos, ainda hoje, tanto pelo prisma literário como pelo historiográfico $^{25}$. Pela questão que se impõe, Esteves e Milton (2007) compreenderam que o essencial não é determinar com precisão onde começa a História e termina a ficção, ou viceversa, mas sim entender que tendo em vista a fragilidade de se apreender a totalidade do passado, este acaba sendo descrito pela linguagem e, em partes, pela imaginação.

Contudo, mesmo diante de posturas menos ortodoxas por parte de certos autores, não podemos perder de vista o conceito híbrido imposto ao gênero por Alessandro Manzoni, em 1850, no momento em que considera existir no romance histórico a presença inconciliável de duas forças, a fábula e a história. A primeira ligada à substantivação do termo romance, ou seja, fictício, e a segunda direcionada à verdade, relacionada ao adjetivo histórico. Manzoni defende que, no romance histórico, a parte histórica contribuiria para o fracasso do elemento poético e este seria destruído pelo caráter histórico apresentado. No entanto, Alfred Vigny, no prefácio de Cinq-mars intitulado Reflexões sobre a verdade na arte, apresenta outra postura em relação a esta convivência entre o real e a ficção num mesmo plano ficcional. Haveria, portanto, “[...] duas necessidades que parecem opostas, mas que para mim estão misturadas em uma fonte comum, uma que é o amor pela verdade e a outra, o amor pelo maravilhoso [...]”26 (VIGNY, [1827] 1869, p.3).

Por este motivo, Maria de Fátima Marinho (1999), dialogando com as duas últimas citações, considera que só se torna possível a criação do romance histórico porque o autor aceita esta contradição e requisita de ambas as partes as suas essências, do romance: a invenção; e do histórico: o rigor aos fatos. No entanto, isso não acaba com o dilema autoral na escolha de qual musa sacrificar, se em nome da unidade matar Clio ou, em prol de uma fidelidade histórica, exterminar com Calíope ${ }^{27}$. Especificamente, na versão clássica do gênero, os cultores acreditavam ser necessário Calíope sucumbir aos desejos de Clio, na tentativa de

\footnotetext{
${ }^{25}$ Cf. Esteves; Milton, 2007, p.12-43. Na visão desses autores, todos os exemplos dados podem ser fontes documentais sobre uma época, como valorizados pela sua essência poética.

${ }^{26}$ Tradução nossa: “[...] deux besoins qui semblent opposés, mais qui se confondent, à mon sens, dans une source commune; l'un est l' amour du vrai, l'autre l'amour du fabuleux [...]”.

${ }^{27}$ Ver Pesavento, 2000, p.7-8. Clio, musa da História, e Calíope, musa da literatura, mantêm uma estreita relação de amizade. Ambas dominam a arte de perceber e conhecer o mundo, mesmo tendo métodos, exigências e objetivos distintos uma da outra.
} 
recriar o passado o mais fiel possível. Porquanto, “o romancista histórico, na verdade, enfeita o passado, sem, contudo, negá-lo, pois a verdade histórica deve ser sempre a sua bússola e a sua diretriz” (RIBEIRO, 1976, p.21).

Por outro lado, essa busca incessante por um rigor histórico acaba sendo uma ilusão tanto pelo romancista quanto pelo historiador, na concepção de Dolezel (1988) citado por Puga (2006). Porque tanto a História quanto a ficção não são frequentadas por pessoas reais, mas sim por aproximações daquilo que teriam sido no passado, que podem ser transfigurados dependendo da perspectiva de quem narra e de seus verdadeiros objetivos. Logo, “[...] os mundos ficcional e histórico são incompletos e vazios numa característica da sua macroestrutura, enquanto as escolhas e modificações do romancista são determinadas por fatores estéticos e semânticos” (DOLEZEL, 1988, p.482-493 apud PUGA, 2006, p.17). Já Roland Barthes (1968) vai mais longe ao ratificar que o próprio discurso histórico, como o romance realista, não produz realidades, mas sim cópias do real. Assim sendo, é de se esperar conclusões como a apresentada por Barbara Foley, quando especifica que ao aceitar "o caráter ficcional da narrativa [mesmo se histórica], e estando conscientes de que não existe nenhuma essência linguística específica da ficcionalidade, podemos chegar à morte da referencialidade” (FOLEY, 1986, p.13-14).

Se para Bárbara Foley, independente de o texto ser ficcional ou não, há sempre uma ficcionalidade do real, então, que sentido de realidade é essa que todo narrador tenta alcançar? Segundo Célia Fernández Prieto, “[...] a realidade não é um conceito estático, mas dinâmico, em constante revisão, cujos limites são ampliados ou reduzidos e cuja inteligibilidade só é adquirida através da linguagem (e sua capacidade de representação simbólica do mundo) e comunicação” ${ }^{28}$ (PRIETO, 2003, p.40). Dessa maneira, a sua definição não tem um caráter ontológico, mas pragmático. O conceito de real passa a ser construído por um corpo social que decide o que é ou deve ser algo, baseando-se em seus códigos e discursos convencionados. Nessa medida, a verdade histórica como representação dessa realidade sofre passivamente do mesmo processo: para a sua legitimação nos campos histórico e cultural, ela deve passar pelo crivo de outros historiadores e do público em geral. De forma conclusiva, o atributo de histórico e de literário é relativizado pela pragmática do contexto cultural em que se realiza.

\footnotetext{
${ }^{28}$ Tradução nossa: “[...] la realidad no es un concepto estático sino dinámico, en permanente revisión, cuyos límites se amplían o se reducen y cuya inteligibilidad sólo se adquiere mediante el lenguaje ( y su capacidad de representación simbólica del mundo) y la comunicación”.
} 
Só assim se justifica o porquê de certos textos, antes considerados históricos, passarem tempos depois para a classificação de literário, como é o caso das crônicas de achamento do continente americano. Especificamente, até o século XVIII, isso se deveu porque havia uma ambiguidade para o uso do termo história que poderia representar res gestas (história acontecimento em si) e historiam rerum gestarum (história narração). Devido a isso, toda narração de fundo histórico era considerada como cópia fiel daquilo que realmente aconteceu, e essa verdade não era questionada.

Contudo, este panorama de produção histórica foi reavaliado a partir da produção científica de Taine, que agora possibilitava aos historiadores definir o campo daquilo que era História e de outros textos em que a História aparecia apenas como pretexto. Mas, esse conhecimento não impediu que os românticos, em sua ânsia de promoverem uma formação nacional - permitindo que os portugueses partilhassem de um passado comum - colocassem conscientemente as duas narrativas num mesmo patamar. Fato que ocorreu com o próprio Herculano, que parece ter considerado a História e a novela histórica como dois elementos de atuação convergente, tanto assim, que publicou n’ O Panorama:

Novela ou História qual destas duas coisas é a mais verdadeira? Nenhuma, se o afirmarmos absolutamente de qualquer delas. Quando o caráter dos indivíduos ou das nações é suficientemente conhecido, quando os monumentos, as tradições e as crônicas desenharam esse caráter com pincel firme, o novelista pode ser mais verídico do que o historiador; porque está mais habituado a recompor o coração do que é morto pelo coração do que é vivo, o gênio do povo que passou pelo povo que passa. [...] Esta é a história íntima dos homens que já não são: esta é a novela do passado. Quem sabe fazer isto chama-se Scott, Hugo ou De Vigny, e vale mais, e conta mais verdades, que boa meia-dúzias de bons historiadores (HERCULANO, 1840, p.243).

Embora as defesas de Herculano sinalizassem para uma posição de quase-História ${ }^{29}$ do romance histórico, não podemos esquecer que há pressupostos básicos que permeiam sua composição e lhe confere o caráter de histórico. György Lukács (2011), em seu importante estudo sobre romance histórico, estabeleceu alguns norteadores para a sua definição, a partir da análise feita sobre a obra de Walter Scott. O primeiro e, talvez, o mais importante deles, é o distanciamento temporal que deve haver entre a época narrada, período em que decorre a ação, e o tempo presente do autor. Esta distância permite avaliar os acontecimentos narrados

\footnotetext{
${ }^{29}$ Cf. Campos Matos, 1998, p. 37-39. Mesmo diante dessa vulgarização da história pelo deleite, como afirma este autor, os romancistas históricos não tinham a pretensão de superar a História, pois sabiam da sua condição de complemento. Na verdade, eles, evitando o confronto direto com esta, tencionavam desvendar aqueles episódios negligenciados, os que estavam à sombra da História até então.
} 
com mais criticidade. Como é um elemento caro ao gênero, no prefácio de sua primeira criação Waverley (1814), logo como subtítulo da obra, Its sixty years since, Scott sinalizou a necessidade de afastamento em pelo menos num interstício de 40 a 60 anos $^{30}$. Nesse sentido, Pinheiro Chagas na maior parte de sua produção configura-se como seguidor de Scott, pois apenas dois de seus romances ${ }^{31}$, aqueles que estão mais próximo do momento de enunciação, recriam um período decorrido em meados de 1800, atendendo, portanto, ao princípio de distanciamento.

Uma outra preocupação deve-se à convivência, num mesmo espaço narrativo, de personagens e acontecimentos inventados ao lado de figuras e episódios históricos, sendo que estes dois últimos ajudam no reforço à credibilidade da história que se conta, promovendo, com isso, o efeito de real. Vale dizer que a trama fictícia ocupa o primeiro plano do romance, geralmente desenvolvendo uma intriga amorosa, que tanto pode ter um final feliz quanto trágico. E, por ser o centro, este enredo inventado toma forma graças à peripécia e à intriga, sendo alguns exemplos disso, raptos, assaltos a castelos, duelos, mortos que revivem, intervenções de bruxas, amores contrariados, mulheres rejeitadas, filhos enjeitados, crimes que motivam intermináveis expiações - propositalmente incluídos para gerar suspense na narrativa e manter o interesse dos leitores.

Como último definidor do gênero, a consciência histórica, que fundamenta a recriação do quadro do passado, deve ser assumida como força modeladora não só internamente no romance pelas personagens da trama, mas, sobretudo, no mundo exterior, pelo autor e leitor. Por este fato, como mediador do relato, o autor deve ser aquele que consegue transitar pelas verdades de seu tempo e as de períodos remotos.

Complementando as diretrizes apresentadas acima, Célia Férnandez Prieto (2003) acrescenta outros dados interessantes relativos ao narrador no romance histórico:

a) O narrador é onisciente, situando-se numa posição extragiética ${ }^{32}$ em relação à história que narra. Por isso, são comuns por parte dessa entidade algumas atitudes narrativas, tais como:

\footnotetext{
${ }^{30}$ Ver Marinho, 1999, p.11. Ao trazer à luz os estudos de Avrom Fleishan sobre o romance histórico inglês, esta estudiosa adverte que deve haver "[...] como condição [para] a existência [do gênero. É necessário] pelo menos duas gerações entre a escrita do livro e o momento cronológico do enredo [...]"

${ }^{31}$ Tanto O major Napoleão como Os guerrilheiros da morte reproduzem o período da invasão napoleônica em Portugal. O segundo livro dando destaque à fuga da família real para o Brasil.

${ }^{32}$ Cf. Reis; Lopes, 2007, p.290-292. Este tipo de narrador está numa posição distanciada espacialmente e de modo temporal em relação ao objeto que narra.
} 
1) Mostra-se fingidamente como testemunha do fato que irá contar ou o editor do manuscrito original encontrado que contém as informações verídicas sobre os acontecimentos relatados. 2) Assume-se como pessoa de saber histórico que didaticamente durante a narrativa vai elucidando por meio de informações históricas do período necessárias à boa compreensão dos relatos.

3) Pratica suas habilidades metapoéticas e ideológicas, estabelecendo digressões morais ou filosóficas, bem como traçando comentários sobre a veracidade do manuscrito que serve de fonte para a história que conta ou sobre a própria construção ficcional.

4) Situa-se anacronicamente no mesmo plano temporal que o leitor e quanto ao narrado.

Todos estes ingredientes elencados estão intrinsecamente ligados aos princípios de verossimilhança e de didatismo, que se apresentam como o cerne do romance histórico, e que diretamente se relacionam ao fato de o romancista histórico pintar fielmente o retrato de uma época e das individualidades que ali viveram. Também na medida de Lukács, uma obra só pode ser considerada romance histórico se estiver atendendo à observância desses preceitos. Por isso, algumas obras, cujas publicações sejam anterior a de Waverley, só são “[...] histórico[a]s apenas por sua temática puramente exterior, por sua roupagem”( LUKÁCS, 2011, p.33).

Pelo trajeto que percorremos da abertura do capítulo até aqui, na tentativa de conceituar o romance histórico, pôde-se perceber o terreno intrincado que subsiste esse subgênero do romance. Devido à dificuldade em conjugar essências tão contraditórias no processo narrativo, de um lado, a invenção inerente ao romance e, de outro, a verdade própria da História oficial, não há como evitar a promoção de discussões intermináveis sobre a matéria. Para fechar, embora o gênero apresente essas fragilidades, “ [...] o que importa para o romance histórico é evidenciar, por meios ficcionais, a existência, o ser-precisamente-assim das circunstâncias e das personagens históricas” (LUKÁCS, 2011, p.62).

Na seção a seguir, pretendemos entrar no universo de produção do romance histórico português, com vistas a elucidar a concepção do gênero para Pinheiro Chagas. Para tanto, iniciaremos com a análise de sua crítica aos romances históricos de outros escritores contemporâneos para, em seguida, apresentar a sua fórmula do gênero, que vai se distanciando gradativamente do modelo tradicional romantizado até se estabelecer num projeto literário, que o próprio romancista considera como história dramatizada. 


\subsection{Pinheiro Chagas, da crítica ao romance histórico}

Com a sensibilidade romântica, o romance histórico vai tanto ser instrumento de formação histórica, como ajudar na consolidação da literatura nacional. Fossem, portanto, nas veredas literárias de Scott, Dumas ou de Hugo, os autores do período oitocentista, cada qual a sua maneira, quase sempre com o olhar voltado para o período da fundação da nacionalidade, utilizaram-se do didatismo e dos ensinamentos históricos para estabelecerem um confronto binário entre passado/presente.

Apesar de centrarmos nossa discussão em romance histórico, o estudo sobre o drama histórico, realizado por Teófilo Braga (1871), nos informa mais elementos sobre as produções de cunho histórico no Portugal de Oitocentos. Neste, seu autor assevera que apesar de ter havido um empenho considerável da classe letrada na adoção do gênero literário, respeitando todas as suas especificidades, suas tentativas iniciais foram inexpressivas ${ }^{33}$. Isto porque, embora os escritores nacionais tivessem contato com um variado número de exemplares franceses traduzidos ${ }^{34}$, para escrever romance de fundamentação histórica, era imprescindível um conhecimento apurado da História e, além disso, que a mesma estivesse consolidada. Desses volumes traduzidos, nenhum alcançou maior glória ante ao gosto popular do que os de Voltaire. Ainda, conforme os estudos de Braga (1871), as tragédias voltaireanas eram admiradas porque defendiam a liberdade de consciência contra despotismo e o obscurantismo religioso, e por isso tiveram muitos seguidores, principalmente no drama histórico.

Essa precariedade de embasamento histórico levará ao surgimento, como adverte Ana Isabel Vasconcelos (2008), de dois grupos que tomaram a História em perspectivas diferentes, sendo que uma mais aproxima do referencial histórico e outra distanciada deste compromisso, ou seja, mais historicizantes. Esclarece, ainda, que o termo histórico vagamente associado a muitos escritos do momento não derivava particularmente de suas autorias, mas da crítica que, sem levar em conta a relação estabelecida entre História e ficção, englobava todas estas publicações num único conjunto, sem distinção.

Embora o cientificismo histórico tenha se originado no século XIX, não podemos nos esquecer que este período era de transição. Nesse sentido, a historiografia portuguesa oscilava ainda entre aquela feita na perspectiva liberal e científica e outra de cunho tradicionalista e

\footnotetext{
${ }^{33}$ É nosso dever informar que, apesar da inepta ficcionalização histórica desse período, no universo de produção concernente ao primeiro Romantismo, algumas produções literárias sobressaem pela forma como constroem o texto pela vertente histórica, configurando, portanto, um isolado grupo de volumes que podemos considerar como dramas históricos.

${ }^{34}$ Vale lembrar que muitas dessas traduções tinham qualidades ruins, o que prejudica a formação dos escritores da época, no que tange aos conhecimentos históricos e particulares do gênero.
} 
conservador. Ser progressista era ter o máximo de compromisso com o discurso histórico na ficção, do contrário, não passava de uma descrição cênica do passado.

É curioso que embora se tenha produzido dramas históricos relativos à época medieval no interstício de 1846-1856, nenhum desses autores recorresse como fonte documental ao primeiro e mais importante estudo histórico de oitocentos, A História de Portugal, de Alexandre Herculano. Nem com a possibilidade de encontrarem um estudo coeso e sério sobre o período de formação de Portugal, os quatro volumes não foram atrativos para essa classe de literatos. Confirmando-se, portanto, certa resistência e incapacidade de manusear o novo saber histórico. Possivelmente, ao optarem pelas fontes mais remotas, especificamente as crônicas, os romancistas pretendiam conhecer a História feita no calor da ação do passado. De interpretação mais digerida, o texto cronístico se destaca dos outros pelo estilo simples de narrar, pelo seu caráter sintético, realístico e urgente da escrita, bem como pelo tom líricoreflexivo que se dá aos relatos dos fatos.

Antes de Herculano, a escrita da História, como asseverou Pinheiro Chagas, era ad narradum (para se narrar), tinha características tão próximas da poética ${ }^{35}$ que quase não havia comprometimento com a verdade histórica. De modo geral, suas censuras creditavam à maioria desses estudos os adjetivos de amadores, demasiadamente fantasiosos e declamatórios. A mais grave delas era a forma idealista com que se desenhavam as personalidades nacionais, engrandecendo-as nos feitos e qualidades, aspectos que comprovadamente nunca existiram na vida pregressa dessas individualidades. A outra reprovação era a forma erudita desses ensaios, no uso excessivo do latim ${ }^{36}$, que produziam uma dificuldade de interpretação do fato.

Na avaliação final de Ana Vasconcelos (2008) ${ }^{37}$, os romancistas históricos românticos preferiram, por vezes, duas formas de conhecerem a História. No primeiro caso bem mais usual, temos as incansáveis leituras das crônicas, muito pelo seu aspecto narrativo, pitoresco e de realismo acentuado. Mas há, ainda, pesquisas isoladas feitas em documentos oficiais,

\footnotetext{
${ }^{35}$ Aqui na acepção de ficção, estória.

${ }^{36}$ É tão recorrente nos escritos de Pinheiro Chagas esse assunto, que ele, até mesmo, criou uma personagem caricata, o Conselheiro Castro - em O segredo da Viscondessa - que só falava em latim e defendia tudo que se referisse à cultura romana.

${ }^{37}$ Cf. Vasconcelos, 2008, p. 79-95. No tratamento da história no drama romântico português, a autora elenca alguns volumes relacionados à produção historiográfica, que serviram de fontes documentais, tais como Inéditos de História Portuguesa, publicados pela Academia, já dos textos seiscentistas, aparecem Garcia de Rezende, Rui de Pina, Rodrigues Acenheiro e Faria e Sousa. Acrescentado à lista, citamos as Lendas da Índia, de Gaspar Correia, por ser o original que Pinheiro Chagas consulta, mesmo não tendo sua referência no artigo em análise.
} 
manuscritos, relatos orais $^{38}$ e publicações de artigos em periódicos ${ }^{39}$, os quais são confidenciados aos leitores, por meio de notas finais, em suas introduções ou prólogos.

Com isso, houve por parte dos romancistas um furor na busca de fundamentação histórica, registros que esclarecessem a vida medieval nacional. O passado, então, funcionava como um script para o presente, lugar privilegiado para se conhecer as verdades religiosas e as intemporais paixões humanas. Mas como advertem Chaves (1979) e Marinho (1999), não foram todos os períodos históricos que os românticos privilegiaram. O medievalismo exagerado ocorreu somente na primeira fase romântica, atenuando-se a partir do segundo momento desta estética, conforme ilustra a obra de Rebello da Silva. Depois disso, houve um decréscimo do gênero, que passou a ficcionalizar um passado mais recente. Dessa lista se excetuam os romances históricos de Camilo que são elogiados pela crítica de Chaves, “[...] pela magia da linguagem em que estão escritos, pelo poder estético que possuem ali onde se fundem os elementos fictícios com elementos históricos, caldeados nas vivas paixões humanas” (CHAVES, 1979, p.54). Assim, o que importa, no final de contas, não é a descrição pormenorizada do ambiente, mas falar da essência humana, sem fazer parecer que é desta que se fala. Seja como for, romance histórico ou citadino, para Candido, o importante é reconhecer:

A ficção [...] [como] um lugar ontológico privilegiado: lugar em que o homem pode viver e contemplar, através de personagens variadas a plenitude da sua condição, e em que se torna transparente a si mesmo; lugar em que transformando-se de si mesmo, verifica, realiza e vive a sua condição fundamental de ser autoconsciente e livre, capaz de desdobrar-se, distanciar-se de si mesmo e de objetivar a sua própria situação. [...] Somente quando o apreciador se entrega com certa inocência a todas as virtualidades da grande obra de arte, esta por sua vez lhe entregará toda a riqueza encerrada no seu contexto (CANDIDO, [1968] s.d, p.38).

\footnotetext{
${ }^{38}$ Ver Vasconcelos, 2008, p.85. Segundo a autora, no discurso preliminar dos Inéditos de Histórias Portuguesa da Academia, um de seus colaboradores inscreve que se trata de estudos históricos inovadores que buscaram fontes originais até então desconhecidas pela classe letrada “[...] com a candura e a justa severidade que a matéria requer, os fundamentos do que dizem e o grau de fé que merecem [entendeu a Academia] em publicar livros antigos, memórias e monumentos da Monarquia, fazendo sair do pó estas testemunhas [para mudar ] o que Portugal tem sido" (SERRA, Academia, 1790 [tomo I]: VII-XI).

${ }^{39}$ Idem, p.87. A História começa a ter uma divulgação em larga escala na mesma proporção que o folhetim. Nesse sentido, o conhecimento histórico começa a ser democratizado. Ana Vasconcelos acredita que "“...] Com o crescente interesse pelos assuntos históricos, são constantemente publicados, nos novos periódicos, artigos que nos dão a conhecer episódios da nossa história [portuguesa] e que terão eventualmente também servido de base ou de enriquecimento aos assuntos dramatúrgicos. Naturalmente que $O$ Panorama, dirigido por Herculano, dedicou grande parte do seu conteúdo a esses assuntos. É também nos periódicos que vamos encontrar informações bibliográficas relativas a novas publicações, como acontece com o anúncio da publicação dos Anais de El Rei D. João III, de Frei Luís de Sousa, pela mão de Herculano, explicando-se 'como se fez a achada deste precioso manuscrito, que se julgava perdido, tantos anos havia, com grande lástima dos estudiosos, assim da história com da língua portuguesa””.
} 
Posto isso, na próxima seção, pretendemos analisar as censuras feitas por Pinheiro Chagas a algumas obras de Arnaldo Gama, que sempre foi lembrado pela crítica pelo rigor histórico com que compunha os seus romances. 


\subsubsection{Os senões aos romances históricos de Arnaldo Gama}

Antes de 1866, Pinheiro Chagas já publicava artigos literários nos diversos periódicos e revistas, como $O$ Panorama ${ }^{40}$. Surge, nesta data, a resolução de reunir alguns desses textos, feitos nos primeiros anos de jornalismo, e editá-los sob o título de Ensaios Críticos. Logo depois, não demorou em sair os Novos Ensaios Críticos (1867), organizado exclusivamente com estudos inéditos. Embora possua apenas estes dois exemplares sob o título de críticas, é sabido que este ofício não cessou até o ano de sua morte, uma vez que publicava diariamente artigos sob variados temas que iam desde arte à política ${ }^{41}$.

Não só Pinheiro Chagas, mas muitos de seus contemporâneos, incontestavelmente, iniciaram desde cedo no jornalismo, especificamente na arte de avaliar a produção literária da época. Mas isso não os impediu de ousadamente assumirem posições muito diversas, às vezes até mesmo em relação ao grupo que pertenciam e, principalmente, ao dos adversários. Seus princípios e métodos como críticos de arte também apresentavam uma hesitação entre os critérios antigos e os então vigentes. Um oportuno exemplo sobre a questão é a crítica do próprio Chagas que, na opinião de Maria Fernanda de Abreu (1994), embora cite Taine em seu prefácio substancioso ${ }^{42}$ e compreenda os seus fundamentos, ele acaba por "[...] abraçar exaltadamente pressupostos duma crítica idealista, mitificadora da 'inspiração' e do 'gênio'” (ABREU, 1994, p.86). Talvez, possamos explicar esta oscilação, pois, apesar de aparentemente acreditar em alguns dos pressupostos tainianos, ele não concordava nem com a estética realista, nem com a naturalista, esta baseada em grande parte na obra desse mesmo autor.

De forma híbrida, parece configurar um horizonte crítico, que faz uso tanto da parte idealista como do cientificismo próprio da tendência moderna, revelado no “[...] espírito observador e criador a um tempo, que analisa as impressões que sente, e que adivinha as

\footnotetext{
${ }^{40} \mathrm{Na}$ abertura do terceiro capítulo de nossa dissertação de mestrado, intitulada $A$ (de) formação da imagem, Pinheiro Chagas refletido pelo monóculo de Eça de Queirós, apresentamos outros nomes de jornais em que ele publicou seus primeiros estudos, dentre eles o Política Liberal, Gazeta de Portugal e Jornal do Comércio, além é claro, de mais outros e o já citado nessa parte da discussão.

${ }^{41}$ Diante da produção intensa de artigos sob variados temas feita por Pinheiro Chagas em diversos periódicos, configura-se uma possível investigação de maneira a reunir, catalogar os assuntos e avaliar as linhas de defesa em tais textos feitos ao calor dos acontecimentos e sob a pressão de entrega. Contudo, esta proposta não será apreciada neste espaço, não só devido aos objetivos peculiares desta tese, mas também pelo caráter inédito e multifacetado que essa nova pesquisa tende a assumir.

${ }^{42}$ Cf. Abreu, 1994, p.83. Na opinião da autora, Pinheiro Chagas fez um "prefácio erudito e substancioso. Ainda que, injustamente, [...] não tenha logrado ocupar esse desejado lugar nas bibliotecas dos cervantistas, não figurando, por exemplo, na já aqui referida Guia de Drake/Finello (1987)”.
} 
tendências dos escritores, tendências que eles próprios seguem sem muitas vezes as perceberem” (CHAGAS, EC, [1866] s.d, p.263) ${ }^{43}$.

Muitos desses princípios críticos estão apresentados nos seus artigos dedicados ao romance histórico, tema que Pinheiro Chagas se debruçou. Dividiremos a nossa análise em dois blocos. Inicialmente trataremos dos dois romances de Arnaldo Gama que foram analisados por Chagas em Ensaios Críticos (1866) - O segredo do abade e A última dona de São Nicolau - ambos criticados pelo excesso de rigor histórico. Em um segundo momento, trataremos de obras de Camilo Castelo Branco e Antonio Silva Gaio respectivamente Luta de Gigantes e Mário - que receberam elogiosas considerações do autor.

Seguindo com a nossa proposta de abordagem, desde o surgimento do romance histórico, os questionamentos aumentaram como forma de se determinar qual das duas instâncias discursivas - poética ou história - era mais importante na estruturação da narrativa. Em reforço a essas considerações, Alcmeno Bastos, num relevante estudo sobre o gênero, aponta que houve dois grupos de defesas que:

[...] viram o romance histórico como versão amena da historiografia, concedendo que ao romancista cabia o reduzido direito de preencher as lacunas eventualmente deixadas pelo registro histórico, nunca, porém, afastando-se do consagrado. De outro lado, os que reivindicavam liberdade ilimitada na manipulação do dado histórico, sob o argumento de que se tratava, em última instância, de ficção, logo, invenção, servindo a história apenas como matéria-prima sobre a qual deveria exercitar-se a imaginação do escritor (BASTOS, 2007, p.11).

Romance ou História, tanto Alexandre Herculano, Arnaldo Gama, Pinheiro Chagas, como outros nomes do período oitocentista, também não conseguiram se desvencilhar dessas questões. O que se percebe é que, ao mesmo tempo em que eles ressaltavam o apreço de ambas narrativas pela verdade do fato histórico, eles não escondiam a eleição do romance como a forma mais agradável e pitoresca para se conhecer o passado nacional.

O livro, que te dedico, encerra uma história verdadeira. De romance há nele somente aquele movimento, aquele pouco mais ou menos do que se sentiu e se disse nos lances, que a tradição nos transmitiu descarnados e sem os enfeites do diálogo e do remexer dos afetos. Isto imaginei-o e por isto é que lhe chamo novela, e não história, porque é por esta feição que a história se desassemelha das novelas, que nelas procuram enredo. No mais é-lhes tudo

\footnotetext{
${ }^{43}$ Ver Chagas, 1866, p.263. Trecho recuperado do artigo em homenagem a Antonio Lopes de Mendonça, quando faz uma avaliação de sua crítica ao considerá-la como "[...] apreciações notáveis pelo estilo elegante em que estão escritas, pela delicadeza, e pelo bom gosto que revelam". Apesar de serem "[...] Memórias [...] uma coleção de impressões, escritas logo que foram sentidas, reunidas depois no gracioso panorama”.
} 
quase comum. Ambas têm de respeitar a verdade dos fatos e do cenário; ambas devem acatar a fidelidade dos caracteres e dos costumes. Naquilo se apartam somente. A história narra o acontecimento seco e desenfeitado; a novela adornara-o com as galas do movimento e dos afetos. A história cinzela o tipo, apura-lhe as formas, cria a estátua; a novela insufla-lhe vida, dá-lhe voz e a faz (sic) caminhar (GAMA, O segredo do abade, [1864] 1951, p.1).

Por isso são encontradas frequentemente nas páginas do gênero digressões metanarrativas e estratégias de autenticidade do relato, caracterizando o romance tão fidedigno ao acontecimento histórico quanto à História. Fato que ocorre em $O$ segredo do abade logo nas primeiras linhas da diegese, quando o narrador, na busca de convencer o leitor da veracidade do seu relato, diz ser o editor da história que irá narrar ${ }^{44}$.

Além dessa hipotética atestação à verdade, que ajuda a confirmar o objetivo didático que os românticos recorrentemente afirmavam ter em suas narrativas. O romance histórico, embora no nível do processo narrativo não se diferencie muito de outros ficcionais, como adverte Harry Shaw (1983), ele exige a presença de uma série de outros pressupostos que se tornam indispensáveis para a sua realização. Dentre estes elementos, podemos elencar ainda a inclusão obrigatória de episódios e figuras históricas na intriga romanesca, bem como a de outros recursos referentes à cor local, que ajudam na caracterização mais precisa da época evocada.

Se a fidelidade à verdade histórica é tão cara na composição do gênero, como dito a pouco, o mesmo não pode ser ignorado em relação aos elementos do romance como: unidade, ação e verossimilhança. Em geral, os senões que Pinheiro Chagas direciona a esses romances centram-se mais na ausência de unidade que se dá entre a História e a ficção, quando o romancista se demora em longas descrições e explicações históricas, ou na ausência de investigação histórica que leva o romancista a fantasiar fatos que não vão de encontro ao já convencionado pela História. Se Camilo fora repreendido por Chagas pela ausência desse domínio histórico, e após esta seção se conhecerá o discutido, o mesmo não ocorreu com Arnaldo Gama, que recebera censuras pela carga melodramática e pelo seu descomedimento histórico que, na opinião deste crítico/romancista, ajudava a enfraquecer a intriga de seus

\footnotetext{
${ }^{44}$ Ver Gama, [1864] 1951, p.276. A estratégia de Arnaldo Gama de dedicar o livro e dirigir-se ao amigo Delfim Maria de Oliveira Maia em passagens dentro da narrativa ajuda no convencimento do leitor de que tudo aquilo que foi exposto tenha realmente acontecido tal como foi contado. "Montei, pois, a cavalo e parti imediatamente, vindo todo o caminho a revolver na cabeça a história que me fora narrada, e, da qual esbocei aí mesmo uma novela, que logo, meu caro Delfim, resolvi dedicar-te, como homenagem prestada pela amizade afetuosa que te dedico, a tua, não menos sincera e não menos verdadeira”.
} 
romances históricos. Estes conceitos serão novamente retomados por Chagas na seção que escreve sobre o autor de O segredo do abade no Dicionário Popular em 1878:

Arnaldo Gama [...] assinalou-se principalmente como romancista histórico. Dava-se muito às coisas portuguesas, tinha grande leitura das nossas crônicas, e os seus romances envolvem boa lição de história pátria; mas deve dizer-se em honra da verdade que a sua nímia fidelidade histórica prejudicava não poucas vezes o interesse das narrativas. Era pesado, desagradava por isso a maioria dos leitores; mas o que é certo é que se aprendia lendo-o (CHAGAS, DP, vol VI, 1880, p.23).

Para Chagas, o romance histórico de Gama pelo seu caráter didático estava muito mais próximo de um compêndio de História - pela preocupação excessiva que o narrador assumia em informar ao leitor os mínimos detalhes da época revisitada -, do que de um romance. Por outro lado, a sua produção literária não excluía os argumentos românticos. A trama de $O$ segredo do abade comprova isso, quando narra a história de três famílias tradicionais da região minhota que tem a sua ruína determinada pelo amor/ciúme. Quando o fidalgo Duarte Pinheiro, fidalgo da casa de Nespereira, desposa Teresa uma aldeã, isso provoca a ira de D. Leonor de Baião, que se vê preterida por uma camponesa. Mas Leonor é amada por seu outro primo, Vasco Ornelas, que ela despreza em igual proporção. A partir de então, a amizade que existia entre os primos vai sendo minada pelas intrigas que semeia Mateus Simão. O capitão de Passos, ao sofrer certas humilhações de Duarte Pinheiro, vinga-se deste, utilizando-se do ciúme e do ego ferido de Vasco para que este assassine o próprio primo, que era seu concorrente ao amor de Leonor. Esse ponto do enredo se aproxima, em certa medida, à temática clássica de Otelo ${ }^{45}$, de Shakespeare.

Além desse ingrediente romanesco de amores contrariados, há ainda mortes antecipadas de personagens pelas desilusões amorosas ou desgostos súbitos que lhes acometem como ocorre com Leonor e Teresa; e longas expiações devido a crimes hediondos cometidos no passado, como os de Frei Lopo, que manda matar o amante da mulher que desejava e depois a

\footnotetext{
${ }^{45}$ Ver Gama, 1864, p.259-260. "Era terrível o combate que se pelejava na alma daquele desgraçado. O anjo mau começou por fim a levar de vencida o anjo bom. E, contudo, na narração com que Mateus incendiara tão horrivelmente o ciúme e a desesperança de Vasco de Ornelas não havia, como o leitor sabe, mais verdade do que o ter ido D. Leonor a Nespereira e isso mesmo de própria resolução. Em estado normal, o espírito de Vasco não se deixaria sequer abalar pelas grosseiras e avilanadas mentidas do capitão de Passos. [...]. Através, portanto, das névoas que lhe escureciam a razão, Vasco não via senão as visões evocadas pela paixão que o alucinava; e essas estavam sempre a ponto de tomarem corpo e afigurarem realidades à mais somenos palavra e ao mais ligeiro ensejo que condissesse com elas. O ciúme é como embriaguez turbulenta em homem de caráter irritável. Uma gora a maior descrimina e dá corpo às figuras provocadoras que lhe redemoinham em confuso turbilhão na cabeça; e essa visão põe-no logo de pé, feroz e terrível como uma fera”.
} 
violenta. Diante disso, o problema apontado por Pinheiro Chagas, então, seria a falta de habilidade inventiva de Gama em entrelaçar os fios da História com a ficção, uma vez que

[...] o poeta é quase sempre subjugado pelo analisador histórico, [preocupase mais com a elucidação do fato histórico do que com a diegese] e o prazer com que expõe o resultado das suas investigações faz-lhe olvidar bastantes vezes a correção da frase, e essa indefinível qualidade, que consiste em arredondar os períodos em aprender a atenção, e em convidar à leitura com a harmoniosa música das palavras (CHAGAS, EC, [1866] s.d, p.50).

Como vimos, na composição de $O$ segredo do abade há menos intervenção da História, sendo, portanto, dada mais atenção à intriga romântica. Por isso, a invasão francesa, que aparece apenas como uma oportunidade de se discutir sobre o assunto, não é dramatizada. Pelo contrário, ou a História é apresentada pelo narrador nas introduções dos capítulos e nas inúmeras notas finais do livro ou as figuras inventadas tecem comentários sobre as personagens históricas, como o faz Vasco Ornelas que, devido às suas atribuições militares, informa ao leitor sobre os avanços do exército de Soult. No entanto, o que mais incomoda Chagas nesta obra não é tanto a falta de dramaticidade da História, mas o fato de que $O$ segredo do Abade "seria um quadro perfeito, se de vez em quando cores banalmente melodramáticas o não desfigurassem” (CHAGAS, EC, [1866] s.d, p.55).

Ironicamente, o defeito que Pinheiro Chagas ressalta nesse romance histórico de Gama é o mesmo que a crítica atribui a sua produção literária, o melodrama. Sobre tal estilo, Sampaio Bruno chega a considerar que a ficção histórica em Portugal começou a perder as suas características primordiais a partir do segundo Romantismo, decaindo “[...] para uma fácil dramatização de situações amorosas, num quadro de imaginação em que atores vivem com as ideias e os sentimentos do nosso tempo” (BRUNO, [1885] 1984, p.23-24).

Por algumas passagens melodramáticas na trama, principalmente as protagonizadas por Frei Lopo de Baião, Arnaldo Gama parece não conseguir se desvencilhar das suas tendências ultrarromânticas. Embora haja uma aproximação nas trajetórias desse seu frade penitente com a de Frei Diniz, de Viagens na minha terra, eles são indelevelmente distanciados pela verdade de suas atuações nos seus romances. Para Chagas, a encenação do padre de Gama além de piegas, denota uma artificialidade em seus diálogos, que, por vezes, enfastiam o leitor. Assim, “ [...] o tipo de Fr. Lopo, o frade infalivelmente melodramático dos romances históricos portugueses destoa, de um modo verdadeiramente desagradável” (CHAGAS, EC, [1866] s.d, p.55). Vejamos, então, apenas um trecho do que para este crítico seria um problema. 
Aqui Frei Lopo, cuja voz principiava a tremular cavernosa, interrompeu-se de súbito, lançou-se de joelhos e, erguendo os braços para o céu, exclamou indizível exaltação:

- Ó santa mártir do mais negro dos crimes, roga a Deus que me não tire a vida, antes de eu expiar, com o inferno que trago na alma, o muito que te fiz sofrer neste mundo.

Dizendo, o frade atirou-se de golpe com a face por terra e assim esteve alguns minutos, chorando e gemendo dolorosamente. Por fim, ergueu-se e, tomando a mão de Duarte, disse-lhe em voz triste (GAMA, [1864] 1951, p.147, grifo nosso).

Além disso, Chagas não vê propósito na criação do capítulo $O$ antro de lobisomem? em que Duarte, ao buscar a intercessão do tio, vê Frei Lopo se auto-flagelando diante da caveira do amante de Maria nas ruínas do velho solar de Cerzedelo. Parece que o crítico não acredita que esta parte pudesse contribuir para um efeito convincente na composição do padre. Pelo contrário, isso só provava a falta de lógica entre o histórico da personagem e sua aparente identidade sobrenatural. Possivelmente, essa utilização de elementos da literatura gótica no seu romance tenha sido uma forma de Gama agradar o gosto da época, que pendia para as histórias de terror. Lembrando que estas foram exaustivamente exploradas pelos autores da segunda fase romântica em suas produções literárias, influenciados pela intensa publicação de traduções de obras inglesas e francesas de mistério e terror.

Embora Chagas ainda reforce uma ausência de originalidade nas histórias de Arnaldo Gama pelos lugares comuns que recria em sua ficção como “ [...] tipos de doidos [Frei Lopo], que andam a monte, e essa família de mulheres seduzidas [Maria, a aldeã que fora violentada por Lopo de Baião], e filhas encobertas [Teresa, filha desse estupro]?” (CHAGAS, EC, [1866] s.d, p.56) não só reprovações, esta produção recebe. Há elogiosas considerações sobre a construção de capítulos ${ }^{46}$ e por sua galeria de personagens como se pode perceber na cena de confronto entre as duas mulheres centrais da trama: a fidalga Leonor de Baião e Teresa, esta mulher-anjo e aquela mulher-demônio.

D. Leonor e Teresa são duas figuras primorosas. O orgulho satânico da fidalga contrasta de um modo magistral com a timidez angélica da esposa de Duarte Pinheiro. A cena em que o romancista põe frente a frente, bastaria para dar ao Sr. Arnaldo Gama foros de escritor muito notável, de um dos mais notáveis da nossa terra no gênero romance (IDEM, p.55).

\footnotetext{
${ }^{46}$ Ver Chagas, [1866] s.d, p.56. Embora não tenham sido excluídas dos capítulos que mais agradaram Pinheiro Chagas as explicações históricas e as descrições pormenorizadas dos costumes e dos ambientes que travam a ação em $O$ segredo do abade, $O$ viajante, Cenas imprevistas, $O$ morgado de Cerzedelo, A mulher que amava Duarte, Dies irae, O ciúme da mulher soberba parecem ter impressionado o crítico pelo seu valor dramático e inventivo, que prende a atenção e curiosidade do leitor.
} 
Esse embate do feminino entre individualidades diferentes: a arrogância gélida de uma e a fragilidade e inocência da outra vão ser recorrentes também no feminino de Pinheiro Chagas. No entanto, não necessariamente no papel de adversárias, como é posto nessa trama de Gama. Na obra de Chagas, especificamente em O juramento da Duquesa, depois da morte da dama de companhia Inês Mendes, Iria a substitui na figuração da mulher-anjo, tendo, por outro lado, sempre a Duquesa de Caminha, na posição de mulher-demônio. No entanto, o feminino de Chagas, e separamos um espaço mais adiante só para esta discussão, foge ao modelo tradicional da mulher romantizada. Mesmo as mais cândidas, como Inês Mendes, são dotadas de voluptuosidade ${ }^{47}$, que parece ser um indicativo importante para a subordinação do homem ao seu comando. Mas isso, se ela soubesse utilizar esses atributos.

Se em $O$ segredo do abade, Chagas fez estas ressalvas, em A última dona de São Nicolau, o crítico adverte para o fato de: “ [...] esta obra de ser mais estudo histórico do que romance” (CHAGAS, [1866] s.d, p.64). Para Chagas, a excessiva preocupação de Arnaldo Gama em recompor o quadro, “[...] sem ter compenetrado perfeitamente do espírito, da legislação, dos costumes, da índole das eras, que pretende retratar” (IDEM, p.49), faz com que a unidade de sua obra seja comprometida. O descritivismo desmedido não deixa que o narrador se ausente, segundo Pinheiro Chagas. O ideal é colocar a narração na fala das personagens e, assim, deixar que a história transcorra pela dramatização das cenas, produzindo, com isso, uma ilusão do real. Contudo, o que se constata é o contrário, num dos capítulos de A última dona de S. Nicolau, nomeado de O precursor da imprensa, antes da apresentação da personagem secundária Vivaldo Mendes, o copista da trama, o narrador relata de forma pormenorizada sobre o tempo da cópia artesanal antes do surgimento da imprensa, o que pode ser constatado pelo leitor logo na abertura da seção.

As amáveis leitoras deste livro - se por ventura este meu livro tem leitoras que, no pleno gozo de todas as comodidades da civilização deste século, desbaratam a regalada ociosidade que Deus lhes concedeu a ler as farfalharias e futilidades românticas da escola francesa e seus imitadores, impressas em branco e acetinado papel e em tipo primorosamente modelado, nem ao de leve imaginam, decerto, que, antes que o amor da especulação e do lucro inspirasse a Guttemberg o grandioso invento que tão nitidamente lhes proporciona a elas o seu tão querido passatempo, havia uns entes, ignorados, obscuros, sem nome, que passavam a vida inteira, a mocidade e a velhice, curvados sobre extensas tiras de pergaminho, copiando, copiando, copiando sempre livro após livro, exemplar após exemplar, afim de que as lucubrações do sábio e as inspirações do gênio pudessem ser lidas e aproveitadas, não pelas multidões, que para essas não

\footnotetext{
${ }^{47}$ Pinheiro Chagas se utiliza bastante vezes desse termo para qualificar um dos traços de seu feminino.
} 
bastavam eles, mas pelos mimosos da fortuna e pelos favorecidos príncipes (GAMA, [1864] s.d, p.28).

O detalhamento com que narra as descrições históricas ou culturais a todo instante na narrativa faz a intriga perder em movimento, criando uma desaceleração da ação romanesca. Carlos de Passos (1950) assevera que estas frequentes pausas, em que a maneira de antiquário é mais valorizado do que a diegese faz da ficção histórica de Gama mais História do que romance.

A última dona de S. Nicolau [...] assim como O balio de Leça, A caldeira de Pero Botelho, $O$ sargento - mor de Vilar e $O$ segredo do Abade, embora qualificados de romances históricos não sobressaem pela movimentação da urdidura, pela complexidade do entrecho, pelo nímio dramatismo. O que, mormente, os distingue e valoriza é a fidelidade evocativa, a luminosa intensidade com que revivem as figuras e os ambientes sociais de outrora; mercê de tais predicados, [...]. Não dispunha ele de grande imaginação para criar enredadas tramas e complicadas psicologias; contudo, sobrava-lhe alma para sentir e compreender os tempos idos e podê-los reanimar de forma sugestiva, clara e tão verdadeira quão possível, não só quanto às personagens como quanto aos meios sociais e costumes, assim como para os descrever e definir com pujante relevo (PASSOS, prefácio, 1950, s.p.).

Estes aspectos foram pontuados por Chagas tempos antes na mesma medida.

Porque me parece que essas mesmas brilhantes qualidades, que tornam o livro inestimável como quadro completo de uma época, o prejudicam como narrativa romântica. Porque a ação afrouxa forçosamente com os inumeráveis episódios, trazidos na intenção de apresentar ao leitor as diferentes faces da vida portuense nessa idade. Porque os mais perfeitos capítulos da Ultima Dona de S. Nicolau não se prendem estreitamente com a ação principal. Porque Walter Scott teria feito quatro romances com os apontamentos reunidos pelo Sr. Arnaldo Gama para um só. Porque o enredo é apenas o laço que liga aos outros os diferentes episódios, um pretexto para formarem grupo os personagens desse século (CHAGAS, EC, [1866] s.d, p.64).

Três são as principais censuras de Chagas quanto à composição inexpressiva de A última dona de São Nicolau: a) as inúmeras interrupções do narrador para explicar historicamente a época, que dá ao livro mais o caráter de manual de História do que de romance; b) a abundância desnecessária de arcaísmos, que tornam incompreensíveis muitos trechos do livro, fazendo com que o leitor recorra frequentemente as notas de rodapés e finais para compreender sobre o assunto; c) um enredo que se desdobra em duas intrigas amorosas que, 
no final das contas, deixa o leitor muitas vezes perdido na narrativa sem saber ao certo qual foi o último acontecimento ocorrido em cada uma delas.

Assim, embora o título dessa obra remeta à história de amor contrariado entre a cristã Branca Mendes e o judeu Eleazar Rodrigues por convicções religiosas opostas, a diegese começa com a impossibilidade de outro amor, o de Álvaro e Alda, devido à rixa entre famílias. A partir de então, quando se espera que o narrador elucide o porquê desses jovens não ficarem juntos, o capítulo se encerra ${ }^{48}$ com Gama apresentando o histórico de uma personagem que acabara de ser incluída na trama. Apesar de nesse caso ele ter invertido o seu processo habitual - pois Luís Fernando Baldaia ${ }^{49}$ auxilia os irmãos Balabardas a evitarem o rapto de Alda, para só depois o narrador fazer a sua apresentação - a justificativa posterior que ele dá ao leitor não deixa de comprovar a meticulosidade com este autor submetia a sua ficção histórica. “ Antes de passar adiante, cumpre dizer alguma coisa acerca do poderoso auxiliar que Deus deparou aos dois irmãos Balabardas, visto que no revólver do arruído não tive ocasião de o fazer” (GAMA, [1864] 1950, p.61).

Mas essa preocupação excessiva em manter informado constantemente o leitor tanto me matéria histórica quanto em questões metapoéticas era uma das marcas de Arnaldo Gama, que pode ser encontrada por toda a sua obra ficcional. Em prol de reconstituir fielmente uma época, Gama até mesmo se utilizou do falar próprio do período quinhentista, como faz em $A$ última dona de $S$. Nicolau, a que serve de exemplo o fragmento abaixo, em que o narrador descreve o vestuário de Alda:

Rodeava-lhe o pescoço uma esclavagem [uma das mil variedades que havia de colares] de belas granada e vestia um sainho [ espécie de jaqueta comprida e larga; coisa assim a modo dos atuais paletós das mulheres] de meyni verde esmeralda e uma fraldilha [saia] de londres azul, refegada de festos e cingida por uma faixa ou cingidouro de escarlate (GAMA, [1864] 1950, p.33).

\footnotetext{
${ }^{48}$ Ver Gama, [1864] 1950, p. 62. Sob o pretexto de incitar a curiosidade do leitor, o narrador se justifica com as seguintes considerações: "Dadas estas informações e avisado o leitor que deve guardar para mais logo o saber as razões porque Alda e Álvaro Gonçalves ainda não estavam casados - casamento que tão sem estorvos se lhe deve afigurar, pelas razões acima dadas - passo a escrever o capítulo quinto, com a consciência desassombrada e convencido de que neste não deixo peguilho, em que a curiosidade do leitor possa embirrar por falta de explicação".

${ }^{49}$ Idem p.61. A maneira minuciosa como detalha as informações pode ser comprovada nesse comentário colocado no corpo da narração. Neste, quando Arnaldo Gama ao apresentar uma personagem que irá transitar em duas de suas narrativas A última dona de S. Nicolau e em O filho de Baldaia, ele acaba citando como sua saúde debilitada interferia na sua produção literária “ Luís Fernando Baldaia - que será o pincipal personagem de uma outra novela histórica, que, querendo Deus, escreverei em seguida a esta, se me não atraiçoar a mesquinha saúde, com que há anos me acho abarbado - era um belo moço de perto de trinta anos de idade, de aspecto formosamente varonil, de corporatura elegante e reforçada, e valente e cavalheiresco como o armeiro da ponte de S. Domingo, de quem era especial amigo”.
} 
Contudo, Pinheiro Chagas considerava que a fidelidade linguística da época podia trazer mais prejuízos à diegese do que contribuir para a verdade histórica, uma vez que não se efetivava o jogo de leitura entre leitor e autor. Sendo que as várias paradas feitas por aquele para se inteirar do significado dos termos poderia contribuir para o seu desinteresse pela trama. Quando o romancista se utilizava do bom senso em dosar e tentar unir a porção histórica com a ficcional, ele incorria em menos erros de fazer apenas um quadro histórico bem desenhado, ou um enredo que demonstrasse somente os seus recursos de estilistas ${ }^{50}$. Embora Chagas enalteça algumas qualidades de Gama como a maneira com que este autor descrevia os episódios protagonizados pelas multidões, o crítico entende também que, na maioria das vezes, e isso ocorre em A última dona de S. Nicolau este

[...] romancista subjuga[va] demasiadamente a parte dramática à parte narrativa. Porque enfim não era possível fazer-se num só romance um quadro tão perfeito, tão completo de uma época, sem o interesse perder com a demasiada extensão da tela (CHAGAS, EC, 1866, p. 64).

A defesa central da crítica de Chagas é no sentido de que não deveria haver uma sobreposição nem do ficcional sobre o factual, nem vice-versa. Parece que este dá certo destaque à ação romanesca em que o fato histórico pudesse ganhar vida pela imaginação do romancista. Sob esta vertente, a genialidade do romancista histórico não estaria em construir um cenário verídico, mas ordenar com lógica e criatividade a verdade histórica no enredo do romance.

É muito mais difícil escrever um perfeito romance histórico, do que uma história perfeita. O estudo consciencioso da época é indispensável tanto ao historiador, como ao romancista, mas o primeiro cumpriu a sua missão, expondo claramente os resultados que colheu, e compreendendo e fazendo compreender o caráter genérico de uma determinada era. O segundo, além disso, vê-se obrigado a analisar a influência da organização social do passado das paixões, nos costumes, na vida doméstica de cada um dos indivíduos dessa geração, que o historiador estudou em globo, e que o romancista tem de estudar nas suas mais insignificantes frações (CHAGAS, EC, [1865] s.d, p.59).

Como se vê por este trecho, o romancista além do estudo histórico tem que enlaçar a matéria histórica numa trama interessante, de maneira que pareça verossímil e que prenda a atenção e curiosidade do leitor. Caso contrário, o romancista se tornaria apenas um historiador, com o

\footnotetext{
${ }^{50}$ Ver Chagas, EC, [1866] s.d, p. 57 Chagas reprova ao gongorismo de Arnaldo Gama de criar neologismos, que os utiliza com frequência: acachoar e pinguíssimo. " [...] o gênio teimoso do futuro ichacorvos principiava a acachoar”. (Gama, [1864] 1950, p.35).
} 
lúcido propósito de esclarecer o fato. E, o romance histórico, como bem diz Sampaio Bruno, além de (in) formar tinha ainda “[...] a grande missão de reabilitar o gosto nacional” (BRUNO, [1885], 1984, p.29).

Recapitulando, na tentativa de recriar fielmente a vida portuense do século XVI, narrando as inúmeras descrições minuciosas dos espaços, da culinária, das vestimentas, dos costumes em geral, até mesmo incluindo o linguajar da época como fez na narrativa de $A$ última dona de São Nicolau, a leitura desses romances se torna enfadonha e morosa. Nesse sentido, parece que Chagas considerava que o romancista histórico não poderia negligenciar a parte inventiva - que o gênero deve preservar, cuidando para que haja uma organização do fato histórico de maneira lógica e atrativa - em favor de uma caracterização fiel da época. Mas não quer dizer com isso que, para ele, a porção da História, imprescindível para a realização desse tipo de ficção, fosse tratada apenas como mero pretexto para fazer romance. Se isso ocorresse, o escritor prestava um desserviço às causas nacionais, deseducando os leitores quanto à verdade histórica ${ }^{51}$. Este último caso, o romance histórico, para os românticos, exercia um papel importante ao lado da nova História na busca de uma unidade nacional. Assim, era necessário ao mesmo tempo entreter e instruir, por isso eles valorizavam que houvesse a dramaticidade do fato histórico para prender a atenção do leitor.

\footnotetext{
${ }^{51}$ Ver Chagas, EC, [1866] s.d, p.63. Neste aspecto, este crítico enaltece as qualidades de Arnaldo Gama em detalhar fielmente a matéria histórica, que parece bem aproximada aos estudos cronísticos. "[...] o romancista portuense não consente que se lhe desvaire a imaginação a ponto de desfigurar os fatos verdadeiros, e de os diluir em peripécias muito de arrastar os leitores, e de despenhar a história por esses precipícios virentes e floridos, por onde a levam os romancistas da escola de Dumas”.
} 
2.2.2. Duas histórias dramatizadas: uma de Camilo Castelo Branco e outra de Antonio Silva Gaio

Nos estudos destinados à análise do romance histórico produzido em Portugal, organizados nos dois volumes de crítica literária de Pinheiro Chagas, duas obras se destacam pelas observações favoráveis que recebem deste crítico: Luta de Gigantes, de Camilo Castelo Branco e Mário, de Antonio Silva Gaio. Pela trama apresentada nos dois livros, estamos diante de duas composições distintas, uma que se aproxima ao convencionalismo romântico aos moldes hugolianos, e aí incluímos Mário; e outra, exclusivamente concentrada nos fatos históricos, como é o caso de Luta de Gigantes. Curiosamente, durante a sua trajetória de romancista histórico, Pinheiro Chagas fará uso, nas suas primeiras composições no gênero, dessa fórmula romantizada empregada por Silva Gaio para, depois, encaminhar-se gradativamente até adotar definitivamente, nos escritos de maturidade, o modelo mais aproximado àquele em que opta Camilo.

Contudo, para evidenciarmos as considerações feitas a Mário por Chagas, necessitamos antes apontar alguns aspectos estruturais do romance histórico oitocentista. Para tanto, utilizaremos uma síntese proposta por Carlos Mata Induráin (1998) sobre características relacionadas à intriga romântica.

Com o intuito de tornar o elemento histórico mais interessante e prazerosa, o romancista histórico de oitocentos recorre a todo tipo de episódios e peripécias para provocar surpresa e manter acesa a atenção do leitor. Assim, é comum a utilização dos seguintes ingredientes românticos: desafios e duelos; combates singulares; batalhas; assalto a castelos; amores clandestinos ou contrariados; ódios entre famílias, enfrentamentos entre padres e filhos; crimes que provocam longas expiações; mortes por amor; envelhecimento precoce decorrido por sofrimento; raptos; execuções; descrições de armas, vestidos e objetos luxuosos, perseguições religiosas; bandidos e salteadores; votos e juramentos; superstição; feitiçarias; presságios; paixões violentas, conspirações, intrigas palacianas, vingança e pessoas encapuzadas ou mascaradas, são alguns desses exemplos.

Associados a esses elementos, o escritor romântico buscou outros mais, relacionados à literatura gótica ou de terror: fantasmas; vozes misteriosas; estranhos murmúrios; castelos abandonados; passagens secretas; esqueletos; cabeças cortadas; portas mágicas que se abrem com dizeres secretos; instrumentos de torturas; porções de veneno e doses de violência e crueldade. 
Apresentados estes ingredientes advindos tanto da literatura romântica como da gótica, passemos então ao comentário sobre Mário com a intenção de filiá-lo ao romance histórico romântico primeiramente, para, em seguida, pontuarmos as considerações de Chagas expressas no seu artigo intitulado Dr. Silva Gaio.

Mário é um drama político, em que é reconstruído o período em que Portugal moderno ficou sob o jugo de um governo absolutista. Escrito à sombra da morte, Silva Gaio desejava fazer um tributo não só ao pai ${ }^{52}$, que fora vítima da tirania miguelista, mas aos vários anônimos que foram aniquilados brutalmente nesse período, deixando uma legião de viúvas e órfãos na extrema miséria. "Pareceu-me que seria útil lembrar o que a liberdade custou, a muitos que de tal andam esquecidos, e por isto não toleram a liberdade alheia.” (GAIO, [1867] 1984, p.24).

O autêntico argumento que consiste em discutir as atrocidades do governo de D. Miguel é sustentado pelo mote sentimental do amor entre Mário e Teresa, impedidos de ficarem juntos pelas intervenções maquiavélicas do comendador Jorge Pinto. Estabelece-se, por assim dizer, um duelo de forças entre as figuras de Mário, representante do Liberalismo e de Jorge que, por seu turno, encarna as posições absolutistas. Pelo desfecho que se dá à trama, com o casamento de Mário e Teresa e a morte trágica do tirânico Jorge Pinto, percebe-se como o fio narrativo acompanha os fatos históricos iniciados em 1828.

Além do amor contrariado entre os protagonistas da trama, existem outros motivos que se encaixam ao modelo romantizado, como o uso de joia de família, a narração de batalhas ou situações de risco, o fogo provocado para desencadear catástrofes e o desejo de vingança.

São comuns em narrativas românticas personagens apresentarem amuletos ou relíquias familiares para favorecer as suas identificações. A peça pode, ainda, simbolizar o livre acesso, ou a representação da vitória depois de um duelo ou como reconhecimento de serviços prestados, sendo o portador da joia beneficiado com a proteção e favores em retribuição. Como exemplo disso, o pai de Teresa, em seu leito de morte, pede ao irmão padre Maurício que guarde a prenda que recebera do príncipe Eugênio de Beauharnais para uma ocasião de necessidade. No entanto, a joia é roubada pelo pai de Mário que tinha compulsão pelo jogo. Já na cena do roubo, quando a personagem passa por um drama de consciência, percebe-se a tensão do episódio visualizada no seguinte trecho:

\footnotetext{
${ }^{52}$ Cf. Gaio, [1867] 1984, p.54. Há uma passagem dentro da diegese em que o narrador, ao apontar o mesmo juiz que condenara Paulo, uma de suas personagens inventadas, sentenciara o seu pai ao cárcere e à tortura: “ [...] Não admira ... Era o mesmo que, dois anos depois condenava a levar varadas um outro preso, pai de quem escreve estas linhas, e que nos estudos, em Coimbra, fora seu companheiro de casa e quarto! [o pai de Silva Gaio e Paulo]."
} 
[...] A este tempo, e enquanto o vigário dispunha o preciso para a partida de Fernão Guedes, havia na alma deste uma luta afrontosa. O pastor deixara aberta a caixa que tinha o retrato; e o jogador, agora sem recursos, porque supunha preso e roubado o capitão-mor, viu nele a proteção de uma família de príncipes, e nos brilhantes que o cercavam os meios de jogar em Alemanha.

- Tenho perdido tanto - lhe segredava o vício - que agora devo começar a ganhar. Recupero os meus haveres, e restituo isto. É um empréstimo apenas. - É uma infâmia esse pensamento - respondia a voz da consciência e da honra. Queres pagar com um roubo a salvação do filho e atua. É infame! É infame!

-Verás que muda a sorte. Na Alemanha há jogo colossal. Numa noite salvas o perdido, e ganhas a futura herança de Mário, que tens espoliado. E que jogo! Que ardentes comoções! Jogas os brilhantes, e tens sempre o retrato para te proteger!

- É verdade! É verdade! - respondia ele a esta culpada voz (IDEM, p.67).

Mais dramática do que esta cena é aquela em que a multidão faz cerco à propriedade de Jorge Pinto, exigindo-lhe a rendição. Contudo, este preferia a morte a ser capturado por aqueles que sempre lhe foram submissos. Assim, não titubeia em explodir a casa consigo e seus comparsas juntos.

A fúria dos assaltantes parecia demência.

- Deitemos fogo à casa - bradaram muitas vozes irritadas. - Façamos aqui o que ele mandou fazer à casa dos Melos, do morgado da Avançam e de outros mais.

- Vivo! Agarrem-no vivo! - gritava Antonio Marcos, já ferido.

$[\ldots]$

Removeram os feridos para longe, e começaram a lançar o fogo aos carros que tinham encostado às portas, e ao mato que acumularam no pátio. [...].

- Rendam-se! Rendam-se! E entreguem o amo! - Clamavam muitos homens.

Jorge Pinto, exposto aos tiros dos assaltantes, dominava os seus naquele momento, como os havia dominado sempre. Obrigava-os a recarregar as armas e a fazer fogo.

[...]

Os homens olharam uns para os outros, e Jorge Pinto leu-lhes nos rostos a resolução de o entregarem. [...]

- Livres? - perguntaram ansiosos os homens.

- Livres para sempre!

-Mas nós talvez fiquemos já livres se entregarmos o sr. Jorge Pinto ponderou Joaquim em voz alta.

- É possível! - tornou este. - Mas aqui, por ora, ordeno eu. Subam para a sala. Na frente tu, Joaquim, ou te estendo morto aos pés.

Jorge Pinto entrou na sala, e todos, excetuando Joaquim, ficaram espantados ao ver aquele rosto, que pela primeira vez lhes aparecia, à luz ardente do incêndio,

- Vocês devem-me quanto são - disse ele. - Ânimo! Saiamos como tigres. Podemos morrer, mas morremos matando![...] 
Os seus homens caminharam para a janela, e de novo reclamaram as escadas, acusando agora Jorge Pinto de não render-se.

- Alto! - lhes disse Joaquim, com insolência. - Nós havemos de levar o sr. Jorge Pinto. Os nossos crimes são os dele. Se tiver padrinhos, também nós teremos.

$[\ldots]$

- Eu rendo-me [disse Jorge]. Mas não quero sair senão pela porta da minha casa. Arrendem-se as escadas. Ninguém sai daqui pelas janelas.

$[\ldots]$

[...] Perceberam [aqueles que vieram prender Jorge] que o comendador pegava lume a pólvora, e que abalou a terra até grande distância.

Depois desmoronou-se toda a casa num montão de ruínas, donde se ergueu espessa nuvem, constelada de milhões de faíscas (IBIDEM, p.417).

Este episódio é um dentre outros que Chagas cita para confirmar a facilidade com que Silva Gaio desenha as paixões humanas. Na sua concepção, por meio dos efeitos de mise en scène, o autor consegue dar mais realidade ao quadro, de maneira que o leitor se vê e sente inserido na história. Embora pareça muito mais difícil a tarefa do romancista histórico na criação do realismo da cena, pois ele só tem a sua disposição a narração, Chagas considera que isso facilmente se consiga por meio das técnicas do gênero dramático: suprimir o máximo que puder da narração dos episódios, diálogos breves, rapidez de cenas, etc.

Não se pode negar que os diálogos curtos com frases de efeitos ajudam no reforço a este tipo de linguagem teatral: “vivo! Agarrem-no vivo!” Chagas, enquanto romancista histórico, fará essas mesmas incursões em seus livros. Como exemplo, podemos citar o episódio em que Luís de Menezes, pretendente de Clara, e Francisco de Mendonça, o de Beatriz, comentam sobre a necessidade de esclarecer os quiproquós que ocorriam desde que esta inventou um modo de legitimar o uso da mantilha dada por Francisco, principalmente para D. Álvaro:

- Se te não veio procurar ontem, procura-te hoje decerto e, ainda que te não procure, Beatriz é que não pode estar vergando ao peso da injuriosa suspeita de ter um homem escondido em seu quarto. É preciso finalmente desenganar o velho. [Luís Menezes desilude o amigo de achar que o pai de Beatriz não viria ao alcance de Francisco para defender a honra da filha].

-De acordo, mas de que modo! Combinemos.

-Senhores, exclamou Gonçalo entrando apressadamente, o sr. D. Álvaro aí vem subindo a escada. A qual dos senhores é que toca ser hoje Francisco de Mendonça! [refere-se ao fato de eles terem trocado de identidade, por acreditar que D. Álvaro vinha para duelar em honra da filha, mas depois que um se passa pelo outro se sabe que D. Álvaro venho em busca de Francisco, filho de seu amigo].

-Ele já! Exclamou Francisco. O que se há-de fazer?

-Recebê-lo.

-Quem?

- Tu.

-Na minha qualidade de Francisco de Mendonça? 
-Não c’ a breca, não nos lancemos à toa em novas aventuras. Sustenta por meia hora o papel. Depois combinaremos. Nada de decisões súbitas. Eu safo-me (CHAGAS, AMB, [1879] s.d, p.112).

Outra estratégia que contribui para iludir o leitor, fazendo com que ele se sinta parte da narrativa, são as interpelações que ocorrem com frequência nos romances históricos, e quase sempre nessas passagens há indícios de anacronia. Em Mário, Silva Gaio, para descrever o espaço narrativo, inicia o romance de maneira interpelativa: “Conheceis a Beira Alta?” E prossegue no convite ao leitor: “Caminhai para leste, vinde comigo”. Embora o pedido pareça imperativo, mas pelo intuito de convencê-lo a aceitar a viagem, o narrador deixa a cargo do leitor essa decisão:

Vinde, porém, assim mesmo. A hospitalidade é de lá generosa e franca, e na lareira das casas crepitam os cavacos e ramos secos. [...]

Levar-vos-ei ao presbitério de S. Romão: queres vir?

É uma casa solitária, de um só andar, bem rasgada por janelas pouco acima do solo (GAIO [1867] 1984, p.25).

Observando esse processo cinético que aqui se estabelece, provocando uma movimentação ilusória do leitor dentro da narrativa, quem lê O corcunda de Notre Dame, de Vitor Hugo, poderá encontrar trechos semelhantes. Geralmente, estas conversas com o leitor costumam vir antes ou intercalando grandes exposições descritivas sobre o tempo e/ou espaço históricos. Como o abaixo citado:

Se o leitor permitir, tentaremos descobrir em pensamento a impressão que ele experimentaria conosco, transpondo o limiar daquela sala grande, no meio daquela multidão em surcot, em hoqueton e em cotte-hardie.

Antes de tudo, zumbido nos ouvidos, deslumbramento nos olhos.

Acima de nossas cabeças uma dupla abóboda em ogiva, com lambris esculpidos em madeira, pintada de azul, com flores-de-lis em ouro; sob nossos pés, um pavimento de mármore branco alternado com mármore preto. A alguns passos de nós, uma enorme pilastra, depois outra, e mais outra; ao todo sete pilastras em todo o comprimento da sala, sustentando no meio da sua largura as bases da dupla abóbada.

[...]

Imaginemos agora essa imensa sala oblonga, iluminada pela claridade descorada de um dia de janeiro, invadida por uma multidão variegada e ruidosa, desviando-se ao longo das paredes e girando em volta das sete pilastras, e já teremos uma ideia confusa do conjunto do quadro, do qual vamos tentar indicar com maior precisão os curiosos detalhes.

$[\ldots]$

O velho palácio estaria ainda de pé, com sua velha sala grande; eu poderia dizer ao leitor ' ide vê-la', e estaríamos assim dispensados, os dois, eu de fazer, e ele de ler uma descrição como esta. O que prova esta verdade nova: 
que os grandes acontecimentos têm consequências imprevisíveis (HUGO, [1831] 1973, p. 22-23, grifo nosso).

Nos dois trechos selecionados, o de Gaio e de Hugo, percebe-se um leitor que caminha lado a lado com o narrador, sendo ambos testemunhas do relato. Só que este, por conhecer melhor o caminho, vai ciceroneando aquele pelo espaço campestre ou citadino, apontando-lhe o necessário para sua ambientação.

Este tipo de estratégia de certa maneira ameniza a monotonia das descrições. O narrador dos romances de Pinheiro Chagas por vezes irá convidar o leitor a acompanhá-lo pela esfera ficcional. Uma em especial pode ser recortada em sua primeira produção no gênero, $A$ virgem Guaraciaba ${ }^{53}$.

\begin{abstract}
Queiram agora os nossos leitores subir conosco a ladeira que vai ter ao alto do monte de Nossa Senhora da Ajuda, onde avulta a igreja, recentemente construída, dos jesuítas, e passando sem entrarmos no templo, insinuemonos misteriosamente pela porta (que lhes entreabrirei com minha vara mágica de romancista) de uma pequena e modesta casa pegada com a igrejinha. Atravessemos uns dois ou três quartos ornados de pobre mobília, e entremos afoitamente, sem receio que nos vejam, numa sala, onde estão reunidos dez ou doze homens, trajando a negra roupeta da Companhia.

A sala é vasta, mas não luxuosa, asseada apenas; as paredes são singelamente caiadas de tabatinga, o teto é almofadado em forma de grade, disposição necessária para se obter uma ventilação refrigerante nestes climas ardentes (CHAGAS, AVG, [1866] s.d, p.83-84).
\end{abstract}

Como podemos ver Vitor Hugo ocupou um importante papel na produção do romance histórico em Portugal. Ele era para os românticos como um “[...] educador não só estético mais também ético e político [...]” (MEDINA, 2001, p.8). E Silva Gaio parece não fugir a esta regra de adesão, já que uma de suas personagens, Jorge Pinto, assemelha-se à outra de $O$ corcunda de Notre Dame, Claude Frollo. Interessante é que Pinheiro Chagas vai ressaltar a beleza de criação que é esta personagem em função de sua impressionante malignidade, conseguindo, até mesmo, obscurecer os protagonistas Teresa, Mário e padre Maurício. A passagem da cadeia é um exemplo do que vimos comentando. Nela, o comendador Pinto barganha a soltura de Fernando Garcia em troca de tornar Teresa sua esposa, para que ele

\footnotetext{
53 Por trechos iguais a este, Marcelo Pellogio sugere que há uma filiação de Pinheiro Chagas às obras de Alencar no seu primeiro romance histórico. Mas as aproximações não param por aí, este autor ainda sugere que o próprio nome ‘Guaraciaba', que é encontrado numa das notas de Iracema reforçaria “[...] um processo claro de filiação estética [a José de Alencar]” (PELLOGIO, 2006, p.127).
} 
pudesse desfrutar de todas as prerrogativas do matrimônio. O trecho é longo, mas necessário, faremos, contudo, os cortes possíveis, que favoreçam a sua exposição, mas sem prejuízo de sentido.

-Meu caro senhor - prosseguiu Jorge Pinto com o seu modo desdenhoso. Estou resolvido a salvá-lo.

-Hum! - murmurou Garcia desconfiado.

-Que dava o sr. para se livrar da forca, e para viver longe de Portugal?

$[\ldots]$

- [...] Eu não sou para mistérios, Sirvo-lhe! Por que preço me vende a salvação da vida?

- Vai admirar-se - disse o comendador, cruzando uma perna sobre a

outra.

- É possível.

[...]

- Dando-lhe para esposa uma mulher bela como um anjo...

- Compreendo. Eu vou ser o véu dos seus amores, e dos frutos...

- Engana-se, meu caro senhor. A mulher nunca foi minha amante; e juro-lhe que não acha outra mais pura.

-É linda?

-É uma formosura; e boa e cândida.

[...]

-Com a fortuna! Anjo, anjo, anjo!

[...]

-Isto é sério?

-Eu não gracejo nunca - respondeu-lhe o comendador.

-Mas este quadro é muito luminoso! Há-de haver, por força, alguma sombra.

[...]

-Imponho apenas uma condição...

- Hum!...

-Que?! Admira-se?[diz Jorge]

-Não. Venha a condição.

-A mulher... não é sua mulher - disse Jorge Pinto.

$[\ldots]$

-O sr. Garcia, com os direitos de marido, leva-a para toda parte, mas não lhe toca com um dedo, sequer. Nem mesmo a olha como sua irmã. Recebe-a por esposa na igreja; vai com ela para onde eu ordenar; e depois... com o dinheiro que eu lhe dou, vai viajar para onde quiser ...

-E fica o sr. Jorge Pinto com ela?

-Justamente!

[...]

-Dou-lhe esta noite para meditar.

-Ah! Não é preciso - atalhou Fernando. - As meditações estão feitas. Não sou santo, e aceito a condição. Reconheço a infâmia, mas penso que tenho vinte e dois anos; que tenho quizila à forca, e que desejo viver, viver e viver! Se tiver remorsos lanço-s sobre o sr. Jorge Pinto, que é o demônio que veio tentar-me.

$[\ldots]$

-Tem sofrido? [por Teresa não amar a Jorge] 
-Quem? Eu? - disse Jorge Pinto com o sobressalto do homem despertado de repente. - o senhor é doido, Os homens como eu não têm mágoas, nem são lamentados (GAIO, [1867] 1984, p.190-194).

O fascínio, que a jovem Teresa exercia sobre Jorge Pinto, parece similar àquele que Esmeralda desperta em Claude Frollo, o arcebispo de Notre Dame. Este, ao vê-la, dançar sente uma “[...] juventude extraordinária, uma vida ardente, uma paixão profunda” (HUGO, [1831] 1973, p.61). O mesmo acontece com Jorge ao deparar com Teresa pela primeira vez ${ }^{54}$. No entanto, quando ambos são rejeitados pelas duas, eles prometem vingança. Jorge promove várias pressões psicológicas, coagindo Teresa a aceitá-lo como marido. Por outro lado, Frollo por acreditar que Esmeralda é a encarnação do demônio chega a torturá-la fisicamente. O amor dilacera esses dois homens que vão sendo consumidos pelo desejo e pela impossibilidade de possuir as mulheres que desejam, fazendo com que percam aquilo que lhes é mais caro, a astúcia. Este aspecto pode ser evidenciado pelas confissões de Jorge, depois que inventa vários pretextos para ver Teresa ou saber notícias da mesma. “- Que fraqueza de espírito é esta, que me quer transformar em pajem apaixonado?” (GAIO, [1867] 1984, p.66).

Como dissemos, Jorge é uma personagem completa, que sobrevive por si mesmo. O seu antagonismo fascina mais do que o caráter nobre dos protagonistas, como afirma Pinheiro Chagas. Por esta construção e outras qualidades estéticas explicitadas pelo crítico, Mário é o resultado das “[...] paixões humanas bem estudadas, uma época inteira soberbamente ressuscitada, enleiando-se tudo numa teia de supremo interesse” (CHAGAS, NEC, [1867] 1890, p.263). Ao afirmar isso, apresenta-se, portanto, o conceito de uma das duas convenções de romance histórico de que se utilizou Chagas no decorrer de sua produção. Nessa narrativa, há um maior desenvolvimento da intriga romanesca e uma menor intervenção da História. Os títulos no gênero em que segue este modelo pode ser encontrado em A virgem Guaraciaba, Os guerrilheiros da morte, O terremoto de Lisboa, As duas flores de Sangue, A corte de D. João $V$, A mantilha de Beatriz e a Marquesa das Índias ${ }^{55}$. As suas outras ficções históricas encaixam-se no que Chagas chama de história dramatizada. Embora haja ainda uma dose de efabulação romanesca nesses volumes, seu autor engenhosamente busca acontecimentos do passado negligenciados pela História, o que possibilitaria mais liberdade de criação, uma vez que não existe uma verdade factual convencionalizada sobre o período. Assim, o romancista

\footnotetext{
${ }^{54}$ Ver Gaio, [1867] 1984, p.64 “ Jorge Pinto deu um passo para aquela angélica aparição, que nunca vira nem imaginara, e, enlevado, quase respeitoso repetiu em voz baixa: - Que beleza! Que beleza!”

${ }^{55}$ Apesar de nessas narrativas as personagens históricas conviverem lado a lado com as inventadas, aquelas são também submetidas ao plano do enredo romântico. Além dessa característica, estes três últimos livros citados recebem na sua composição à interferência do modelo de capa e espada desenvolvido no teatro de Calderón.
} 
histórico não confrontaria a História, muito menos incorreria na divulgação de inverdades históricas. Como primeiras tentativas no segundo tipo de romance estão A conspiração de Pernambuco, O major Napoleão, A máscara vermelha e O juramento da Duquesa. Já os três últimos títulos que faltam dessa lista, A descoberta das Índias. Contada por um marinheiro, A joia do vice-rei e O naufrágio de Vicente Sodré constituem a consolidação da segunda fórmula no gênero como narrativa ideal, filiando-se de certa maneira ao modelo camiliano empregado em Luta de Gigantes.

Dito isso, passemos, então agora, à análise da crítica de Pinheiro Chagas aos romances históricos do autor de Amor de Perdição.

Embora Camilo, em uma carta a Castilho, confessasse: "O Pinheiro Chagas decidiu que os meus romances históricos estavam muito longe de serem históricos” (BRANCO, [1866] s.d, p.98), essas reprovações não foram suficientes para demovê-lo dos seus projetos literários no gênero, que continuaram numa produção intensa. Durante o período de 1865-1867, Camilo dedicou-se ao romance histórico ou à novela histórica, termos que alternavam, dependendo de sua avaliação, para designar essas obras, e que parecem comprovar sua indefinição. Para ilustrar o discutido, apontamos duas posições distintas que se respondem a esse propósito. Por exemplo, em $O$ olho de vidro, Camilo, depois da epígrafe do título de O olho de vidro, inscreve-o como romance histórico. Já Luta de Gigantes, em que a efabulação se dá em menor intensidade, seu autor renuncia a uma classificação, transferindo esta responsabilidade a terceiros:

\footnotetext{
Não lhe chamo romance, porque é história autenticada por documentos, não lhe chamo história, porque seria presunção imprópria da minha humildade aforar-me em fidalguias tamanhas. Os catálogos das livrarias dêem-lhe o nome que muito quiserem; e o leitor, segundo a indigestão que lhe fizer o livro, qualifique-o, e ate-o, se lhe parecer, à capa surrada de alguma crônica de franciscanos (BRANCO, [1865], 2006, p.9).
}

Portanto, mesmo não sendo proposta desse espaço analisar essas obras de maneira mais detida, mas recuperar trechos para compreender o posicionamento crítico de Pinheiro Chagas quanto a estes romances, optaremos pela designação mais acolhida por Camilo, a de romance histórico, para todos os volumes publicados nos dois grupos. Assim, orientados pela divisão proposta por Jacinto Prado Coelho (1982), temos a seguinte organização editorial. No primeiro grupo, prefiguram-se Luta de Gigantes, $O$ santo da montanha, $O$ olho de vidro, $O$ judeu e O Senhor do Paço de Niñaes. De outro lado, aparecem a trilogia iniciada com $O$ regicida. 
Conhecido esse expressivo número de títulos, precisamos, antes de tudo, compreender as motivações que levaram Camilo a se interessar por esse tipo de romance. Para isso, mesmo não considerando adequada para a compreensão do conjunto da produção camiliana a equação biografia-obra, proposta por Jacinto Prado Coelho (1983), consideramos pertinentes duas razões apontadas por este crítico. A primeira consistiria no valor comercial que cada publicação representava, já que o público da época nutria grande interesse pelos assuntos históricos, como também afirma Chagas num dos seus prefácios ${ }^{56}$. E Camilo, como profissional das letras, vai escrever aquilo que está mais ligado ao gosto desse leitor, pois sabe que se tratava de vendagem certa ${ }^{57}$. Outro estímulo estaria no fato de que, neste período, Camilo volta-se para as leituras históricas, que certamente forneceram novas sugestões para seus livros.

E será por essa vereda, a do esgotamento imaginativo, que Pinheiro Chagas justifica a presença do autor de Amor de Perdição na produção de romances históricos. No entanto, nesse ensaio, as suas primeiras considerações não são animadoras, pois Chagas não só ressalta aquilo que ele considera como os deslizes camilianos, como desqualifica as composições de $O$ Judeu e O Olho de Vidro, ambos de 1866, como romances históricos. Diferentemente da avaliação positiva feita a Luta de gigantes e ao Santo da montanha, considerados como os melhores trabalhos do gênero.

Nos senões a Camilo, o motivo que interferira na qualidade desses romances enquanto históricos estaria a excessiva romantização do período pretendido. Assim, a História não passava de pretexto para desenrolar uma intriga, pois não havia uma exploração dos fatos históricos em si.

A faculdade, que no espírito de Camilo Castelo Branco sobreleva a todas as outras, é decididamente a da observação. A imaginação vem depois. Camilo reproduz admiravelmente o que vê, mas não adivinha com idêntica facilidade. Demais, está habituado ao trabalho rápido e sem preparativos, trabalho em que a pena, correndo pelo papel, vai reproduzindo os modelos que lhe pululam em torno, sem precisar estar sujeito a um plano concebido

\footnotetext{
${ }^{56}$ Ver Chagas, [1890] 1910, p.6. No prefácio de O naufrágio de Vicente Sodré, seu autor elucida que o público da época tinha cada vez mais “[...] curiosidade que se manifesta pela avidez com que são lidas todas as monografias, seguidos todos os estudos que tem por fim descobrir e trazer à luz novas particularidades relativas a homens conhecidos ou a épocas curiosas [...]”.

${ }^{57}$ Ver Branco, 1866, p.5. Camilo dá mostras de como as pressões pecuniárias e as dos seus variados editores orientavam suas escolhas de publicações. No prefácio de $O$ olho de vidro, ele confidencia “Os termos em que o convite é feito animam e ao mesmo tempo assustam. Comecei temerariamente a composição deste romance: mau foi principiá-lo, que eu sou tão pouco de aprimorar escritos desta ordem, que não me forro ao perigo de concluílos e imprimi-los, ainda quando me desagradam”. Pinheiro Chagas lembra que quando Walter Scott esteve endividado, ele necessitou produzir obras históricas por encomendas. Contudo, para este crítico, elas não fizeram jus às obras primas como Waverley e Ivanhoé.
} 
anteriormente A reprodução de uma geração extinta com todo seu tumultuar vertiginoso de tipos diferentes dos nossos, de diversas instituições, de costumes estranhos aos atuais não se pode de forma alguma casar com esse gênero de trabalho. A fantasia do escritor vê-se obrigada a assemelhar-se então à câmara escura do paisagista. (CHAGAS, NEC, [1867] 1890, p.43).

Quase sempre desprovido de fontes documentais e pressionado pela rapidez com que empreendia seus projetos literários, Camilo, nos momentos de desconhecimento histórico, não hesitava em se apoiar na sua capacidade imaginativa. Contudo, a distorção da História oficial interferia no elemento didático, tão importante para o romancista histórico, se pensarmos nas duas intenções sincréticas desse tipo de literatura, divertir e instruir. Numa das intervenções do narrador encontradas em $O \mathrm{Judeu}$, ele evita reconstruir o inquérito das testemunhas do Santo Ofício contra Antonio José da Silva por puro despreparo histórico. “Aqui é o ponto de colher os panos à imaginação, e encostar-se o romancista ao pouco de que pode amparar-se para não escorregar no plano inclinado das hipóteses impróprias do assunto” (BRANCO, 1866, p.208).

Mas isso não quer dizer que não haja uma preocupação com a autenticidade da história que conta, Camilo não foge à regra do gênero. Por isso, frequentemente, utiliza-se de cartas e passagens históricas para firmar o procedimento de verossimilhança junto ao leitor. Nesse tipo de literatura, sua preferência está em situar o narrador ou relatar um acontecimento pelo interesse do caso e não pelo que nos possa ensinar a respeito da história ou pelas relações existentes entre o caso e a história. Desse modo, de ironia em ironia, ele vai estabelecendo um grau de veracidade naquilo que conta, seja por meio do recurso paratextual de notas de rodapés, pela transcrição de trechos de textos históricos ou literários escritos no próprio corpo da obra ou colocados na boca de suas personagens.

É importante ressaltar que, apesar das críticas desfavoráveis a Camilo quanto à sua capacidade de criar um romance verdadeiramente histórico, Pinheiro Chagas reconhecia a aura inventiva deste autor.

E quem há aí em Portugal que saiba contar como Camilo Castelo Branco? Haverá muitos na Europa que rivalizem com ele? Haverá muitos que saibam suspender o leitor dos bicos da pena, e fazê-lo seguir, sem as excitações das grandes peripécias e das grandes paixões, a narrativa despretensiosa em todos os meandros por onde lhe apraz divagar? Ah! É tão difícil esta arte de contar bem, de conversar com o leitor, de lhe cativar a atenção apenas com a justeza do pensamento, com o mimo do estilo, com a verdade da observação, com a frase elegante realçada por um fino sorriso [...]. (CHAGAS, NEC, 1867, p.54). 
Como já foi dito em outro lugar deste texto, no romance histórico há uma intenção. Ele não é inocente. E com a sua produção, os romancistas históricos românticos tencionavam não só colocar em discussão de maneira irreverente o passado para que a nação compreendesse melhor o que é hoje, como acreditavam que conhecer a História nacional era um meio de preservarem sua unidade pátria. Mas para que o leitor confiasse na autenticidade do relato do romance histórico, a sua feitura demandava algumas exigências: a de um maior cuidado na pesquisa, na tentativa da recriação de ambientes e mentalidades, na autenticidade factual do relato, e, por último, na articulação dos componentes romanescos e históricos na narrativa de maneira coerente e, portanto, convincente.

Por alguns desses pontos negligenciados por Camilo, Pinheiro Chagas acreditava que as investidas desse autor no romance histórico foram fracassadas, pois ele “ [...] não [tinham] laços que o prendam, não [tinham] exigências de romance a que atende[sse].” (CHAGAS, NEC, [1867] 1890, p.54). Daí se justifica as inúmeras passagens com incorreções factuais, meramente fantasiosas. Marinho (1999), sobre este aspecto, assevera que é necessário encarar o romance histórico de Camilo não pela semelhança com outro protótipo, mas como expressão do gênero que fala da história à sua maneira e se aproveita dela com objetivos que o leitor ativo pode entender.

Desse modo, parece ser unânime dentre a crítica, como explicita Castelo Branco Chaves, que nos textos de Camilo se assiste sempre ao entrelaçamento da história e da fantasia, podendo-se afirmar, sem grande margem de erro, que "os personagens que tiveram existência histórica são personagens muito seus, inventados ou adivinhados.” (CHAVES, 1979, p.53). De mesma opinião, Marinho considera que “[...] as infidelidades à História são constantes e não há nenhuma preocupação em obedecer estritamente ao que consta de manuscritos ou documentos, apesar de, como veremos, haver, por vezes, remissões que parecem ter um grande ar de seriedade”. (MARINHO, 1999, p.75).

Por isso, os acontecimentos reais só existem para situar no tempo e no espaço, não havendo qualquer preocupação na reconstituição das forças sociais e humanas que permitiram determinada transformação. Como bem diz Pinheiro Chagas, o protagonista da história na obra $O$ judeu é construído de maneira fantasiosa, sem nenhum rigor histórico, pois “ [...] As feições do herói do livro, do próprio Antonio José, nem por sombras acusavam uma individualidade característica. (CHAGAS, NEC, [1867]1890, p.40).

Estas censuras de Chagas parecem ganhar força tempos depois nas palavras de João Gaspar Simões, quando este afirma que 
[...] nunca o romance histórico foi em Camilo aquilo que o romance histórico é nos seus maiores representantes: a evocação objetiva do passado, a reconstituição viva de costumes e fatos pretéritos, a exatidão dos acontecimentos evocados [...] Nem em $O$ regicida, nem em $O$ filho (sic) do Regicida, nem no Senhor do Paço de Niñaes, nem em $O$ judeu se nos depara a ambiência histórica dos séculos XVII e XVIII (SIMÕES, 1987, p.422).

Se em $O$ Judeu e $O$ olho de vidro Camilo não se sentiu seguro nesse terreno, não podemos esquecer que em outras obras históricas, como em Lutas de gigantes e $O$ santo da montanha, Chagas acredita que ele habilitou o espaço como seu. Embora, neste último título, ainda, haja incorreções quanto aos rigores do gênero - como uma maior intervenção da efabulação em muitas passagens históricas - por outro lado, ele se salva pela dramaticidade da História encontrada nas “ [...] cenas interessantes, [n]os diálogos vivos, [n]as peripécias bem traçadas, que desenrola, diante dos olhos do leitor episódios que a sua fantasia pôde facilmente reconstruir [...]”(CHAGAS, NEC, [1867] 1890, p.42). Um belo exemplo disso é o capítulo destinado às festas de Corpus Christi em Braga. Nesse, seu autor narra o pitoresco do ritual regional por meio de um tipo de dramatização da festa do Santíssimo Sacramento. Aqui, são apresentados trechos de canções, falas de algumas divindades e a beleza das alegorias do espetáculo que reunia, num sincretismo religioso, o paganismo e o cristianismo. Vale lembrar que Maria Aparecida Santilli considera que esse episódio apresenta duplamente duas características magistrais camilianas, a primeira quanto à descrição “dos valores da fé ao gosto romântico medieval” e, a última, talvez a mais espetacular, o ato de "adiar os incidentes da trama amorosa, aguçando, pelo hiato, a ânsia da expectativa em quem o acompanha” (SANTILLI, 1972, p.VIII).

Como O santo da montanha se aproxima ao primeiro modelo de romance histórico que Pinheiro Chagas fez uso, em que há uma maior atenção à intriga em detrimento à parte histórica dramatizada, nossa intenção foi mesmo tratá-lo de maneira superficial. Sob esta perspectiva, optamos, portanto, pela discussão de Luta de gigantes, que se aproxima mais daquela convenção de romance histórico afastada do modelo romântico, em que as personagens históricas estão no primeiro plano da diegese. Alfred de Vigny, por exemplo, no prefácio a Cinq Mars defende não só a utilização central de personagens referenciais como confere ao autor a liberdade de alterar fatos históricos, de maneira que a História oficial deve servir também aos propósitos do romancista. Nesse sentido, essa postura torna-se precursora da composição do romance histórico pós-moderno, no século XX. 
No entanto, a maior parte dos românticos, principalmente em Portugal, considerava que o romance não deveria confrontar ou desmentir a verdade histórica. E Chagas, nas suas primeiras considerações sobre Luta de gigantes, ressalta o “ [...] magnífico estudo histórico, que dá princípio a um gênero quase novo entre nós, que mostra os grandes recursos que encontra na história portuguesa quem souber estudá-la, como em toda parte se estuda a história no século atual [...]” (CHAGAS, NEC, [1867] 1890, p.53). Dessa maneira, parece confirmar a sua ideia de que o romance histórico é “ [...] a mais séria e elevada missão [...]”(CHAGAS, EC, [1866] s.d., p.61) a de instruir o povo português em matéria nacional. Elegendo-o, portanto, como fonte de instrução e entretenimento junto aos portugueses, que se mantinham tão alheios à tradição ${ }^{58}$. Por dois motivos este tipo de literatura se encaixava à causa dos românticos, pelo seu caráter informativo e formativo. Chagas se preocupava ainda com a maneira como eram feitas as Histórias, sempre na base declamatória e apologética. $\mathrm{O}$ romance histórico, a seu ver, poderia tentar contar outra versão, mais realística, destituindo o lado místico das personalidades e acontecimentos históricos, começando a vê-los de maneira mais humana e real.

Os nossos antepassados não eram heróis fabulosos, eram homens como nós, e é necessário que estudemos aquelas campanhas, como estudamos por exemplo as campanhas do primeiro império francês. Não basta dizermos Duarte Pacheco, oh! Afonso de Albuquerque, oh! Não se imagine que a história portuguesa se resume em pontos de admiração. Duarte Pacheco era um herói, tudo quanto quiserem, mas estava longe de ser um grande homem! (CHAGAS, NEC, [1867] 1890, p.51).

Estas orientações também sugeridas no prólogo de seu livro O naufrágio de Vicente Sodré são seguidas durante a composição deste livro, que se filia ao modelo camiliano em Luta de Gigantes, no que tange a retratar “ [...] o conhecimento íntimo daquela época sem aparecer sempre com uma solenidade que nos fatiga” (CHAGAS, ONVS, [1892] 1910, p.8). Mas o procedimento não é só esse, é necessário, antes de tudo, que romancista histórico seja um encenador, que tenha “[...] a faculdade de meter em cena, de dispor das decorações segundo as da perspectiva, de fazer mover os personagens de modo que nos pareça que os vemos e os seguimos nas peripécias da sua vida [...]” (CHAGAS, NEC, [1867] 1890, p.55).

Em Luta de gigantes, Camilo se ocupa de um acontecimento mais local do que propriamente um fato de âmbito nacional. O enredo, mais ao caráter de uma tragi-comédia,

\footnotetext{
${ }^{58}$ Ver Chagas, NEC, [1867] 1890, p.48, grifo do autor. Chagas credita a classe intelectual de Portugal boa parte dessa ignorância e descaso à História nacional, pois ela era a primeira “ [...]que se delicia[va] com a leitura da história das nações estrangeiras, ignora[va] completamente a história da sua pátria [...]”
} 
narra a disputa para o cargo de comissário geral entre dois clérigos representantes das famílias dos Césares e dos Mascarenhas, que já vinham de um histórico de rivalidades. Para o escolhido a importância consistia em, mais do que conquistar esta posição, ter o seu rival como subordinado. Por isso, tanto de um lado quanto de outro faz o impossível para conseguilo, e se utilizam de todas as influências possíveis, desde parentes com boas relações em Roma até a maior delas, o dinheiro. Como ironiza o narrador camiliano, ao comentar que Frei Diogo César havia reunido um grupo importante para reivindicar o cargo em seu nome: “[...] Escolheu companheiros, e destes o mais ilustre seria frei Estevão de S. Jerônimo, se ele não levasse consigo outro companheiro muito mais ilustre, que era o dinheiro” (BRANCO, [1865] 2006, p.53).

Embora haja uma intromissão maior da História no livro, é difícil não perceber as intervenções romanescas, é certo que em menor grau, que faz o narrador camiliano. Os ingredientes românticos estão mais presentes no que se referem à vida íntima das personagens históricas. Nesse caso, os episódios em que os filhos de Maria, filha bastarda de Frei Diogo César, revoltosos com a desonra do tio, que era bispo, desejam revanche. Contudo, a mãe intervém e os demove da ideia, dizendo-lhe que bem ou mal, Frei Martinho de Lencastre havia unido seus pais. Há uma construção romantizada dos moços: belos e valentes soldados, que num ímpeto buscam resolver tudo por meio do duelo.

Camilo não se preocupa tanto com a apresentação da História aos moldes escolares, por isso não economiza em suas ironias, que permeiam toda a diegese. Um exemplo oportuno é quando o narrador camiliano troça da participação deplorável de D. João IV como juiz da questão. Por este não ter uma firmeza de propósito estava sempre bajulando um lado ou o outro para se retirarem da contenda. Mas D. João IV estava diante de duas personalidades “senhor [es] absoluto[s] de suas ações” (BRANCO, [1865] 2006, p.53), sedentos de vingança e cheios de vaidades, nos quais pouco efeito fazia os apelos do rei, que mais parecia um súdito diante das vontades dos dois frades. O episódio das luminárias, como assim denominamos, é uma boa prova disso. Com a morte de Frei João de Nápoles, Frei Martinho de Lencastre é destituído do cargo, já que a escolha partira daquele. Diante da derrota do comissário, ironicamente, o narrador comenta: “ Luminárias em todos os conventos de franciscanos! Trevas nos conventos das franciscanas! [alusão à vida libertina de Lencastre, que é desenhado como um boêmio pelo narrador]” (IBIDEM, p. 51). Novamente, restituído o cargo a Frei Martinho pelo poder eclesiástico de Roma, o narrador afirmará "Luminárias nos conventos das franciscanas! Trevas no convento dos franciscanos!” (IBIDEM, p.52). Até que no final desta batalha, Frei Diego é prejudicado de forma fraudulenta por Frei Martinho, obrigando o 
el-rei a substituir os governos provinciais daquele. O narrador comenta: "Não pude tirar a limpo se as freiras puseram luminárias, desta vez”. (IBIDEM, p.52). Pouco tempo depois, D. João IV revoga a sua decisão, restabelecendo todos os direitos retirados aos aliados de Frei Diogo. Acerca desses dissabores e da inconstância que o rei demonstrava, Camilo considera “ [...] Frei Diogo César é admirável de paciência e reverência ao soberano quando a tal respeito escreve: ‘Tantas mudanças faz a paixão e a ambição!’”( IBIDEM, p.53).

Este fragmento indica-nos que para escrever a maior parte da história, Camilo se baseou nas memórias do frei Diogo César, daí se entende a tomada de partido que ocorre inevitavelmente durante a narrativa.

Frei Martinho de Lencastre orçaria por trinta anos, não tinha vocação para frade; ou, se a teve com as ilusões da mocidade, abastardaram-lha as más paixões, espertadas pelo ódio. A ostentação não era a menor de suas culpas. Principiou, ordenando que o tratassem de reverendíssimo. Quis que os sinos dos conventos onde ele chegasse, já de longe o festejassem com repiques. (p.44)

Frei Martinho, pendurado no braço real, escouceou valentemente Frei Diogo, mandando-o recolher-se a um convento de Santo Antonio no Porto [...]. (p.53)

Enquanto, pois, as calamidades e escândalos esbravejavam nas outras províncias, frei Diogo César se estava pacificamente gozando no governo da sua. [...] (p.46)

Frei Diogo César não viria descabido em nosso tempo, se descesse da sua dignidade a redigir uma gazeta. Eu muito gosto da irônica e desempenada agudeza com que ele diz que Portugal é terra tão generosa que enriquece os estranhos e empobrece os seus para mostrar o pouco em que tem as riquezas. (p.50)

O narrador termina a história dizendo que apesar da luta entre os dois clãs ter durado um século, terminara a rixa por meio do casamento de seus descendentes em 1728. Mas a nota final do romance é que nos interessa realmente discutir. Assim, tece o seu último comentário no livro:

Para mim é de fé que este livrinho não vai a mãos de Sras. Exas. Todavia, se por eventual sorte desta livralhada fútil, lá chegar isto, ouso pedir-lhes, das profundezas da minha humildade, que confrontem o período da luta de seus avós, aliás gigantes, com a paz e quietação doméstica de Sas. Exas. Neste período tão malsinado de corrupto; e digam - a mim, não, às suas consciências - qual das duas épocas é melhor (BRANCO, [1865] 2006, p.154). 
O leitor que conhece a ironia camiliana, sabe que esse trecho tem não só um narrador sarcástico, que o convida a não perder o seu tempo lendo futilidades, ${ }^{59}$ mas que provocativo, de outro lado, instiga a sua capacidade reflexiva, que involuntariamente pensa sobre questões similares do passado se repetirem caprichosamente no presente. Nesse ponto específico, Camilo, seja nos romances citadinos ou históricos, parece estar sempre comparando comportamentos com vistas à moralização, com o nítido propósito de mudar o seu entorno. Não sendo à toa o codinome recebido por Pinheiro Chagas de “ [...] o Balzac da limitada comédia humana que se agita neste pequeno palco do Ocidente da Europa” (CHAGAS, NEC, [1867] 1890, p.39).

É o que parece acontecer quando publica Luta de gigantes. Dentre os vários episódios da História nacional ou estrangeira, Camilo poderia ter escolhido qualquer um, mas opta no conturbado ano de 1865 por um fato que se assemelhava ao cenário de inveja e vaidade demonstrado pelos embates na Questão Coimbrã. Trazendo, então, este leitmotiv para o mundo empírico de Camilo, o cargo eclesiástico tanto pretendido pelos dois frades no passado seria nada menos do que a vaga para a cadeira do curso de letras disputada por Pinheiro Chagas e Teófilo Braga. Com a intercessão de Castilho, que não poderia correr o risco da nova geração conquistar espaço no ensino oficial, ele antecipa-se e solicita a posição para o aliado, desencadeando a mais importante polêmica do século XIX.

No período dessa contenda e pouco tempo depois entre 1865 a 1867, Camilo escreveu onze romances, dentre esses sete romances históricos, além de miscelâneas, esboços de apreciações literárias, colaborações jornalísticas avulsas e o texto polêmico Vaidades Irritantes e Irritadas. Este volume teve sua publicação posterior ao ápice da polêmica, mesmo Castilho tendo solicitado que interviesse a seu favor, ele se manteve distante, como observador, e demora a se manifestar. Contudo, quando o faz, escreve esse opúsculo, como parece transportar a mesma questão para o ficcional de Luta de gigantes, revitalizando o mote das rixas literárias de seu tempo com a história entre os Césares e os Mascarenhas. Portanto, se um dos propósitos do romance histórico é sua intervenção no presente, certamente, muitos leitores, senão, os próprios contendores se reconheceram nesse livro.

Este romance impressionou tanto Chagas, que, aparentemente, deste livro camiliano tenha saído o assunto para duas de suas publicações, A máscara vermelha e O juramento da

\footnotetext{
${ }^{59}$ Ver Cabral, 1985, p.53. Esta nota final do livro, certamente é uma resposta às críticas recebidas, principalmente pelas mulheres, na sua primeira publicação que saíra em folhetim. Como se pode comprovar de uma carta de Camilo ao seu editor: “ Remeto hoje a V.Exa. a Luta de Gigantes. É coisa aborrecida. As senhoras do Porto têm dito deste romance pior do que eu poderia dizer delas. É láudano puro”. (28-01-66)
} 
Duquesa, que narram história de conluios, conspirações, vinganças e rixas. No capítulo IV, tratamos desses temas em relação a Pedro Bonete, que aparece citado na introdução da segunda parte de Luta de gigantes. 


\subsection{O romance histórico, um projeto literário}

Ter em mente que os romancistas históricos a partir do ultrarromatismo não tinham nenhuma preocupação com a decadência portuguesa é reproduzir conceitos rígidos e superficiais. Pinheiro Chagas, um dos últimos cultores do gênero, é visto pela maior parte das histórias literárias como um escritor melodramático que se utilizava do pretexto histórico para vangloriar o áureo passado português. As críticas mais contundentes desqualificam as suas composições pela ausência de criticidade em relação ao destino pátrio e pelo estilo folhetinesco que, por vezes, apresenta.

Mas não podemos nos esquecer que a chamada fase de degeneração do romance histórico, a qual a obra de Chagas está associada, foi na verdade uma tendência em que praticamente todos os escritores desse período recorreram aos elementos encontrados nos romances góticos de Anne Radcliffe, nos livros de mistério de Eugène Sue e Frédéric Soulié e nas peripécias das obras de Alexandre Dumas (pai), com o claro objetivo de conquistar o público jovem, especialmente as mulheres. Carlos Mata Induráin (1998) acrescenta a esta lista outras características advindas dos livros de cavalaria, como a técnica do manuscrito encontrado que produz veracidade ao relato. Assim, fizeram parte dessa nova onda literária, além de Pinheiro Chagas, Rebello da Silva, Arnaldo Corvo, Camilo Castelo Branco, Silva Gaio, etc, conseguindo ainda a atenção de romancistas históricos ortodoxos como Arnaldo Gama $^{60}$.

Como se vê, não só o campo estético se hibridizou como também o temático sofreu modificações perceptíveis no gênero. Depois do Liberalismo, os romancistas abandonaram os temas medievais e passaram a preferir assuntos mais atuais, que tivessem ocorrido num tempo mais próximo do presente do leitor. Na opinião de Kurt Spang, essa curiosidade excessiva a todo escrito que tivesse ligação com o histórico era impulsionada pelas “[...] épocas de crise política, filosófica e religiosa [que] costumam ser as épocas em que o romance histórico

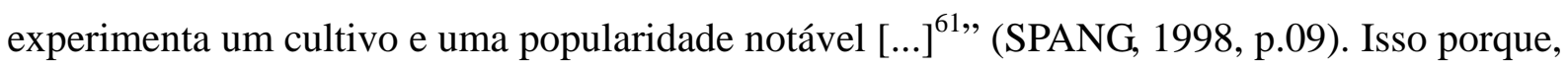
para o leitor, conhecer e repensar o passado é a possibilidade de evitar novos erros no presente. E os românticos acreditavam que nada mais prazeroso e instrutivo do que aprender sobre História no formato romanesco. Nesse sentido, a ficção histórica romântica assumia

\footnotetext{
${ }^{60} \mathrm{O}$ leitor poderá encontrar elementos da literatura gótica, negra e de capa-espada em romances como O segredo do Abade: a suspeita de Frei Lopo ser lobisomem e o lugar sombrio onde ele residia. Em A última Dona de S. Nicolau: A perseguição de Álvaro aos sequestradores de Alda, pode ser um bom exemplo da escola dumasiana.

${ }^{61}$ Tradução nossa: "Las épocas de crisis política, filosófica y religiosa suelen ser lãs épocas en las que la novela histórica experimenta um cultivo y uma popularidad notables”.
} 
claramente a tarefa de restituir o interesse ao discurso histórico ${ }^{62}$, que lhes parecia extremamente maçante. Carlos Mata Induráin (1998) chega a concluir que nessa época muitos “ historiadores [narravam como] romancistas e [os] romancistas [como] historiadores” (INDURÁIN, 1998, p.19). Na verdade, o historiador sabe que, apesar de ele estar subordinado ao rigor científico, de muito lhe vale a imaginação, que é própria da ficção, na organização lógica dos dados históricos. Olhando por este viés, podemos considerar que a História não deixa de ser uma ficcionalização do real, talvez devido a isso se perceba uma tentativa de convencer o seu leitor a todo instante que este relato é científico e não inventado. Como faz Pinheiro Chagas em sua justificativa, antes de narrar o fato da morte de Inês de Castro, na História de Portugal.

Ora, aquele acontecimento [da morte de Inês Pereira] é por si mesmo tão altamente dramático que o mais leve floreado prejudica o terror e a compaixão que ele inspira. Confessamos que nos seduz mais do que as tragédias de Gomes, Quita, e mesmo de Ferreira, a narração ingênua, tocante e terrível dos velhos cronistas. É verdadeira e simples, isso basta para que seja dramática; tendo agora que expor também aos nossos leitores um tão sabido sucesso, vamos cingir-nos às crônicas dos vetustos historiadores; falta ao nosso estilo o encanto nativo daquelas páginas, onde revivem as crenças e pensamentos daquela época, mas sem procuramos romancear o episódio, havemos de expor os fatos com toda a sua singeleza (CHAGAS, HDP, [1878] 1899, p. 236, grifo nosso).

Se a História, depois do cientificismo, buscava distanciar-se da invenção do romance, por outro lado, o romancista histórico empregava todo tipo de estratégia para validar o seu discurso como verdadeiro, como esclarece Joseph Tuner (1979), em seu estudo sobre o romance histórico oitocentista. Mas essa preocupação do autor com o realismo histórico é quase sempre fingida, porque os meios de autenticidade apresentados por ele são sempre inventados. Seja sob a forma de um manuscrito encontrado ou pelo fato ter sido testemunhado pelo seu interlocutor, o narrador vai ser o editor da história.

Contudo, mesmo configurando um estudo rigoroso da época, expressando o caráter didático desse tipo de romance, isso não quer dizer, como assevera Brian McHale (1987), que ele tenha a intenção de superar a História oficial. Pelo contrário, há uma respeitabilidade aos fatos e as pessoas já consagrados pela verdade histórica. E para se evitar o confronto com o registro dessas histórias, o romancista estrategicamente se debruça sobre as áreas obscuras da

\footnotetext{
${ }^{62}$ Pinheiro Chagas é um dos defensores da ideia de que algumas crônicas, principalmente as do século XVI, dão gosto de lê-las pelas qualidades estéticas que apresentam como o arranjo poético discreto, a simplicidade de estilo e criticidade na descrição do episódio. Por isso, o emprego do verbo restituir.
} 
historiografia. Dito de outra forma, o escritor, objetivando a verossimilhança, vai se ater aos espaços em branco, o das lacunas deixadas pelo discurso histórico oficial. Como foi uma das vias utilizadas por Pinheiro Chagas para obter mais liberdade de criação no seu modelo de História dramatizada, que tem no plano central da trama personagens históricas, como em $O$ naufrágio de Vicente Sodré e A joia do Vice-Rei.

Desse modo, definir o momento a ser ficcionalizado é a primeira medida a ser tomada pelo romancista histórico na concepção de Jean Louis Picoche (1978), citado por Carlos Mata Induráin (1998). No entanto, para sua escolha só lhe restam duas possibilidades: ou o autor opta por um período desconhecido, como já comentamos, ou destaca somente um episódio isolado, aquele mais conhecido pelo público. Decidida por uma das duas condições, Picoche (1978) considera que haverá um equilíbrio entre o elemento histórico e o inventado. Pois se há um exagero do primeiro, o romance deixará de sê-lo para se converter em compêndio de História. De outro lado, a ausência de embasamento histórico faz com que o passado seja apenas tratado como pretexto, como pano de fundo para o narrador situar a sua trama.

Anne Ubersfeld (2008) concorda com esse recorte histórico proposto por Picoche (1978) e acrescenta que mesmo nessa escolha, eram suprimidos alguns dados históricos, que não se faziam de forma aleatória. O primeiro motivo devia-se ao fato de o romance não comportar a narração completa do tempo e espaço. E o segundo, tendo um campo histórico mais reduzido, o autor não incorria no risco de enfraquecer a sua intriga, como salienta também Kurt Spang $(1998)^{63}$.

Sintonizada nas mesmas matérias das críticas anteriores, Ana Vasconcelos (2008) considera que tão importante quanto conhecer as fontes em que se debruça o romancista, é interpretar a sua seleção, pois ela elucida não só a sua concepção de mundo, mas também os seus ideais políticos:

[...] este grupo de dramaturgos [...] procurou na História momentos que, de alguma forma, espelhassem a situação política e social, a que se opunham, tentando deste modo iludir a censura, ao enfatizarem os valores em que acreditavam e pelos quais lutaram [...] (VASCONCELOS, 2003, p.249).

\footnotetext{
${ }^{63}$ Este último aspecto destacado consiste em uma das censuras que Chagas faz ao romance, A última dona de S. Nicolau, de Arnaldo Gama, já explicitado por nós na seção, Os senões aos romances históricos de Arnaldo Gama, p.44. Pinheiro Chagas ressalta, numa comparação entre as escolhas históricas de Arnaldo Gama e Walter Scott, que este último só por se ater a um estreito período, já possibilitou a produção de bons títulos.
} 
Em seguida, na tentativa de exemplificar o argumento das preferências históricas dos românticos, esta autora organiza um conjunto de seis acontecimentos-chaves que, em sua opinião, a primeira geração, renitentemente, buscou evocar. Apesar de Pinheiro Chagas não fazer parte desse grupo, será nosso propósito, sempre que possível, exemplificar o período com um título deste autor, com o intuito de evidenciar as suas escolhas.

1). A época de transição da era medieval à moderna: A descoberta da Índia. Contada por um marinheiro (1890), de Pinheiro Chagas.

2). A formação da nacionalidade portuguesa, sendo uma dessas publicações Dulce (1850), de Bento de Carvalhais.

3). A crise dinástica de 1383-85, Período conturbado e revolucionário no que se refere às questões nacionais, que abrange os reinados de D. Fernando e D. João I. Um dos títulos que remonta essa época é D. Maria Teles, de Rodrigo d’ Azevedo.

4). O período sebastiânico: Fortalecimento de crença messiânica de que o retorno de D. Sebastião restituirá a independência a Portugal. Um clássico quanto ao gênero e à temática, Frei Luís de Sousa (1844), de Almeida Garrett.

5). A restauração de Portugal: Fim da dominação filipina. Das publicações, temos como títulos dos romances históricos de Pinheiro Chagas mais lembrados pela crítica A máscara vermelha e O juramento da duquesa, ambos de 1873, sendo o primeiro continuação do segundo.

6). A administração pombalina: $O$ terremoto de Lisboa, de Pinheiro Chagas, publicado em 1874.

Ainda que esta organização proposta por Vasconcelos seja um direcionamento para elucidar mais o processo de composição dos romances históricos de Pinheiro Chagas, é preciso afunilar a questão e nos debruçarmos sobre o porquê de umas escolhas e não de outras. Possivelmente a resposta para isso esteja na tese levantada por ele em 1872, com o propósito de conquistar uma vaga para a terceira cadeira do Curso Superior de Letras. Na sua argumentação, sob o título de Desenvolvimento da Literatura Portuguesa ${ }^{64}$, Chagas expõe

\footnotetext{
${ }^{64}$ Ver Quental, [1872] 1926, p.235-240. Antero de Quental, que também havia feito um artigo opondo-se às opiniões de Braga sobre a origem do povo português, julga as conclusões da tese de Chagas lúcidas e sensíveis, apesar de algumas divergências de pensamento, que não desmereciam o estudo. Em seguida, o autor de Odes modernas estende-se numa linha filosófica sobre "ser português" e sua relação com o passado nacional. Elogia as ideias tão bem discutidas de Chagas no estabelecimento de que a ciência é o suporte imprescindível para reafirmar que a história literária dos portugueses teve sim uma importância fundamental no universo europeu. Concorda com Chagas, que a saída não estava nessa estranha "salvação", para a qual seria necessário deixar de serem portugueses, abdicando-se o pensamento lusitano por meio da imitação da cultura germânica. Finaliza suas considerações, ressaltando que o caráter eminentemente nacionalista de sua tese não desmerece sua
} 
seis prováveis proposições para a decadência das letras em Portugal. Embora não seja especificamente um texto direcionado à imagem nacional, tomamos a liberdade de desdobrálo como se fora, pois a própria discussão do autor não estabelece uma dissociação entre a condição nacional e literária.

As discussões centram-se nos seguintes pontos:

$1^{\circ}$ - A origem do povo português é arturiana e não moçárabe, como se pensava a intelectualidade de então;

$2^{\circ}$ - Tampouco, Portugal tinha uma origem germânica, sua constituição é hispano-romano, sendo a aristocracia advinda da cultura gótica;

$3^{0}$ - A existência mais produtiva dos portugueses foi durante o período medieval, sob o regime municipalista. Nesse período, a produção literária teve mais originalidade e fôlego. Dentre os grandes nomes, destacam-se Gil Vicente e Fernão Lopes com suas crônicas ${ }^{65}$.

$4^{\mathrm{o}}$ - A literatura aristocrática sofreu influências francesas e italianas, como ocorrera em outros países peninsulares;

$5^{\circ}$ - O século XVI foi caracterizado pela latinização do saber, tornando os textos dicionarizantes e elitistas. Contudo, houve em Portugal algumas personalidades que se sobressaíram por sua espontaneidade criativa, simplicidade de estilo e originalidade, manifestados na epopeia de Camões, nas comédias de Gil Vicente e nas crônicas dos descobrimentos;

premissa de que o desprezo dado pela historiografia universal às iniciativas literárias de Portugal é muito mais um problema do próprio olhar português, que não reconhece a sua importância no desenvolvimento do espírito humano mundial por meio da arte.

${ }^{65} \mathrm{Cf}$. Chagas, 1872, p.32-35. Neste texto, seu autor estabelece um contraponto entre a escrita de Fernão Lopes e os outros cronistas de seu tempo, chegando à seguinte conclusão: “[...] Fernão Lopes é um vulto verdadeiramente grandioso; não só historiador, mas poeta, e poeta em cujo ser palpita a alma de um povo. Aiala é o cronista político, julga friamente os acontecimentos, e friamente os narra; Froissart é o cronista aristocrático, só vê os esplendores da nobreza, as justas e os torneios, Fernão Lopes é o cronista popular, vivaz e apaixonado". Em outro ponto do ensaio, considera-o como um escritor dramático, pelo seu realismo histórico e poesia. “ [...] mostram como Fernão Lopes possui as faculdades criadoras que o escritor dramático servem para criar personagens cheios de verdade humana, ao historiador para reconstruir um mundo desaparecido nas ruínas do passado”. 
$6^{0}$ - A decadência literária portuguesa deu-se por meio de três fatores: o despotismo monárquico e centralizador, que imperou nas raças neolatinas; o despotismo religioso, com a presença do jesuitismo nos países de língua latina - principalmente em Itália e Espanha - e a perda da nacionalidade devida a circunstâncias históricas ${ }^{66}$.

Não é nossa intenção tratar todas as proposições detalhadamente ligadas ao ficcional, mas especificamente a sexta ideia que, recorrentemente recuperada nos romances históricos de Pinheiro Chagas, toma forma nas reconstituições históricas dos séculos XVI ao XIX. No quadro, disponibilizamos os romances históricos de Chagas por temas priorizados e o período destacado.

\begin{tabular}{|l|l|}
\hline \multicolumn{2}{|c|}{ Romances Históricos de Pinheiro Chagas por temáticas } \\
\hline A virgem Guaraciaba (1866) & $\begin{array}{l}\text { Anticlericalismo - Período da } \\
\text { união ibérica no espaço colonial } \\
\text { brasileiro. A presença francesa no } \\
\text { Rio de Janeiro. }\end{array}$ \\
\hline $\begin{array}{l}\text { A conspiração de Pernambuco } \\
(1866)\end{array}$ & $\begin{array}{l}\text { Período da união ibérica no } \\
\text { espaço colonial brasileiro. } \\
\text { Conjuração para a Independência } \\
\text { colonial das possessões } \\
\text { estrangeiras (Holanda). }\end{array}$ \\
\hline A corte de D. João V(1867) & $\begin{array}{l}\text { Despotismo monárquico e } \\
\text { anticlericalismo }\end{array}$ \\
\hline O major Napoleão (1867) & $\begin{array}{l}\text { Despotismo monárquico - } \\
\text { Invasão napoleônica em Portugal }\end{array}$ \\
\hline Os guerrilheiros da morte (1872) & $\begin{array}{l}\text { Despotismo monárquico - } \\
\text { Invasão napoleônica em Portugal }\end{array}$ \\
\hline A máscara vermelha (1873) & $\begin{array}{l}\text { Despotismo monárquico e } \\
\text { anticlericalismo - Período da } \\
\text { Restauração pós-união ibérica }\end{array}$ \\
\hline O juramento da Duquesa (1873) & $\begin{array}{l}\text { Despotismo monárquico e } \\
\text { anticlericalismo - Período da } \\
\text { Restauração pós-união ibérica }\end{array}$ \\
\hline O terremoto de Lisboa (1874) & $\begin{array}{l}\text { Período de Restauração } \\
\text { pombalino }\end{array}$ \\
\hline Revolução Francesa \\
\hline As duas flores de sangue (1875) & $\begin{array}{l}\text { Período de Restauração pós- } \\
\text { união ibérica }\end{array}$ \\
\hline
\end{tabular}

\footnotetext{
${ }^{66}$ Ver Barata, 2000, p.107-128. Refere-se à crise dinástica com a morte de D. Sebastião e boa parte da nobreza na batalha de Alcácer Quibir em 1578. O reino foi gravemente empobrecido pelos resgates aos cativos. Com isso, foi o fim da Dinastia de Avis e do processo expansionista advindos da vitória na batalha de Aljubarrota. A partir de então (1580), Portugal fica à mercê da dinastia Filipina por sessenta anos. Na União Ibérica, Portugal e Espanha, era governada por Filipe II. Muitos textos portugueses produzidos neste período obrigatoriamente eram escritos em língua espanhola. Contudo, o teatro de Francisco Manuel de Melo é um dos poucos que insiste numa produção portuguesa, obtendo sucesso num ambiente artístico estritamente espanhol.
} 


\begin{tabular}{|l|l|l|}
\hline A marquesa das Índias (1890) & $\begin{array}{l}\text { Período colonial } \\
\text { portuguesa }\end{array}$ \\
\hline A joia do Vice-Rei (1890) & $\begin{array}{l}\text { Período colonial }- \\
\text { portuguesa }\end{array}$ \\
\hline $\begin{array}{l}\text { A descoberta das Índias. contada } \\
\text { por um marinheiro (1890) }\end{array}$ & $\begin{array}{l}\text { Período expansionismo marítimo } \\
\text { português }\end{array}$ \\
\hline $\begin{array}{l}\text { O naufrágio de Vicente Sodré } \\
\text { (1892) }\end{array}$ & $\begin{array}{l}\text { Período colonial } \\
\text { portuguesa }\end{array}$ \\
\hline
\end{tabular}

Desde a crítica oitocentista, a produção literária de Pinheiro Chagas parece não convencer de que ela pudesse problematizar a realidade nacional sob uma perspectiva histórico-moral $^{67}$, como fez de modo incisivo e eloquente a Geração de 70 . Tudo que se tem dito sobre as obras deste autor até então é que elas conservam um tom apologético em relação ao passado nacional, sem citar ou mesmo assumir a situação de decadência de Portugal. No entanto, não é o que se percebe depois que se lê o conjunto de romances históricos. Embora ele tenha para si que há um potencial enorme de criação entre os portugueses ${ }^{68}$, Chagas defende que a nação quase sempre esteve à mercê de uma direção nefasta de seus reis, motivo que justificaria a sua ruína. O rei exercia, portanto, um papel decisivo no destino da nação.

Pois então, só porque um rei morreu, e só porque se perdeu um exército, que não era grande coisa, perdeu-se Portugal? [alusão à fracassada tentativa de D. Sebastião em Alcacér Quibir, que culminara em sua suposta morte] É assim mesmo. Faltou rei, faltou tudo, porque o povo nem já sabia de si, e as cortes, quando não havia quem mandasse alguma coisa, nem sabiam o que haviam de fazer (CHAGAS, HAP, 1880, p.98).

Outro historiador de seu tempo Oliveira Martins, em Portugal contemporâneo, também apresenta a degradação nacional como “ [...] uma sucessão de atos voluntários, de planos de estadistas” (MARTINS, [18?]1951, p.92). Para ele, o declínio do país teria iniciado na Dinastia de Avis com D. João I, em que reinou o que ele denomina de trindade augusta $^{69}$ : rei (mestre), o jesuíta (o fundador do novo reino) e o inglês (o guia). Já Pinheiro Chagas considera que a decadência se origina tempos depois na mesma dinastia, no governo de $\mathrm{D}$.

\footnotetext{
${ }^{67}$ Ver Lourenço, 1982, p. 85-126. No capítulo “ Da literatura como interpretação de Portugal”, este autor elabora um panorama das produções literárias de Garrett a Pascoaes e suas posições críticas em relação à decadência de Portugal. Lourenço considera que Garrett é o primeiro escritor que coloca em xeque a real situação da nação, antes da Geração de 70, que tempos depois elaborou um “ [...] estatuto de desconfiança ou até de suspeita grave em relação à nossa realidade nacional enquanto existência valiosa, atingiu de súbito uma expressão paroxística [...] paradoxal.”

${ }^{68}$ Ver proposição número 5 neste estudo.

${ }^{69}$ Ver Martins, [1880 ] 1951, p.162. Denominação dada por este autor que considerava que o regente ia sendo educado pelo jesuíta e explorado e ludibriado pelo inglês.
} 
Manuel, período em “ $[. .$.$] que morreu a grandeza de Portugal” (CHAGAS, HAP, 1880,$ p.92), devido à maneira descuidada com que ele tratou os assuntos coloniais. Não há dúvidas sobre a existência de pontos de contato entre a tríade elaborada por Oliveira Martins e as quatro causas que Chagas aponta que favoreceram o assolamento do país:

a). A educação jesuíta que converteu Portugal numa nação devota e inerte diante de outras nações como Espanha, França, Inglaterra e Holanda;

b) A alienação de Portugal que sempre se manteve alheio às transformações no continente europeu;

c). A má administração de seus monarcas transformara Portugal num país dependente da tutela de França e Inglaterra, concorrendo fatalmente para as perdas das suas colônias.

d). O envolvimento em guerras desnecessárias ou alheias, originando perdas econômicas, políticas e humanas;

Em análise, a assertiva $\boldsymbol{B}$ e $\boldsymbol{C}$ são consequências de $\boldsymbol{A}$ se pensarmos na doutrina de submissão pregada pela Companhia de Jesus, que formava indivíduos facilmente influenciáveis, beatos e passivos. Como também a proposição $\boldsymbol{D}$ não deixa de estar ligada ao jesuitismo e às alianças feitas principalmente com Inglaterra.

Outro parâmetro, que podemos levantar, estabelece-se com o texto As causas da decadência dos povos peninsulares, de Antero de Quental. Percebemos que há entre as discussões de Chagas e Antero, salvo leve diferença, uma significativa aproximação. No referido ensaio anteriano, seu autor afirma que Portugal e Espanha estavam à frente da Europa até a Renascença e que, a partir do século XVI, três fatores foram decisivos para o declínio da península: a monarquia absoluta, o Concílio de Trento e o expansionismo marítimo. Apenas neste último aspecto, os dois autores não concordam, já que a terceira causa deve-se, para Chagas, à perda da nacionalidade para a Espanha, depois da morte de D. Sebastião, que enfraquecera politicamente Portugal.

E quando Chagas cita o reinado de D. Sebastião ${ }^{70}$ parece-nos que este se encaixa como resultado dessa equação proposta pelos três autores. Vejamos. Para a execução da destemperada ação de D. Sebastião em perseguir os mouros em África, foram decisivos a sua

\footnotetext{
${ }^{70}$ Cf. Marinho, 2002, p. 365. Não se pode perder de vista que, por trás da enigmática morte de D. Sebastião, era favorável para nação a construção do mito, pois "a vontade de que o rei não tivesse morrido, [era] vontade emotiva, mas também política e ideológica”.
} 
educação fradesca e o seu amor pelas batalhas. Em relação a isso, Pinheiro Chagas compara a atitude de D. Sebastião, em matéria de religião e de guerra, como quixotesca ${ }^{71}$.

[...] gostava de guerras e batalhas, fez-se ao mesmo tempo beato [devido à influência de seu tio, o cardeal D. Henrique, que vivia cercado de padres]. Parecia um daqueles antigos frades militares, que tinham concorrido tanto para expulsar os mouros de Portugal. Não quis casar, e até fugia das mulheres [...]. Mas D. Sebastião, com aquela embrulhada, que ele tinha na cabeça, de ideias religiosas e de ideias guerreiras, não atendia a coisa nenhuma, nem fazia cálculos nenhuns. O que ele queria era dar lambada nos mouros, e, apesar dos conselhos de toda a gente, levanta um pequeno exército, e para o levantar custou-lhe, porque já não havia braços no país ... co’ a breca, que eles não chegavam para tudo! [...]

Ah! Meus amigos, aquilo era mesmo um doido que ali ia. A gente gosta de ver um rapaz que tem o sangue na guelra, e que se atira para adiante, embora faça asneira, mas é que D. Sebastião estava perfeitamente maluco. Era maluquice a empresa, foi maluquice o modo como a dirigiu. Parecia que Deus, por umas poucas de vezes, o quisera salvar, e ele sempre a atirar consigo de cabeça para baixo (CHAGAS, HAP, [1880] s.d, p. 94).

Além do rei-menino, Pinheiro Chagas elenca ainda D. João III e D. Maria I como monarcas que mais sofreram a influência do jesuitismo. D. João III instituiu a inquisição em Portugal e a rainha revogou o ato de expulsão dos jesuítas, elaborado pelo Marquês de Pombal, trazendoos de volta a Portugal e aos liceus. Contudo, o leitor só obtém essas informações pela introdução histórica que abre o primeiro capítulo das seguintes obras: D. João III em $A$ marquesa das Índias e A virgem Guaraciaba, D. Sebastião em A conspiração de Pernambuco e D. Maria I em As duas Flores de Sangue. Esta rainha, em Os guerrilheiros da morte, aparece numa cena completamente louca no momento em que a família real deixa Portugal.

A beatice desses três dirigentes vai ser também uma marca nos outros reis que transitam pela ficção histórica de Pinheiro Chagas. O primeiro deles, D. Manuel (A descoberta das Índias; A joia do Vice-Rei e O naufrágio de Vicente Sodré) é retratado como um homem religioso, conivente, ambicioso e mau administrador. Segundo Pinheiro Chagas, ele tinha claramente a intenção de fazer das conquistas ultramarinas um negócio lucrativo. Assim, do rei ao marinheiro, todos ambicionavam comerciar e enriquecer sem muito esforço em terras coloniais.

[...] uma grande parte dos desastres sucedidos aos portugueses, ou das dificuldades em que se viam metidos, provinham da sofreguidão com que se tratavam principalmente de ir às presas ao mar vermelho, não

\footnotetext{
${ }^{71}$ Alusão que o leitor pode encontrar no prefácio que Pinheiro Chagas faz da tradução de D. Quixote.
} 
respeitando os navios dos nossos aliados pela pressa que tinha todos de enriquecer.

Foi esse o erro capital da organização das nossas conquistas orientais. $\mathrm{O}$ Estado fez-se comerciante, e consentiu que o fossem também os seus servidores. [...]

[D. Francisco de Almeida] Empregava todas as razões que lhe acudiam ao espírito para aconselhar que se não mandassem navios ao Estreito [apesar das recomendações e permissão de El-Rei, o Vice-Rei era contrário a prática desleal de comércio entre portugueses e os nativos], e era contudo essa a grande ambição dos oficiais portugueses, e uma das constantes recomendações do governo de Lisboa. Ali se faziam as presas rendosas; o rei obtinha assim pimenta de graça, e os oficiais resgatavam-se amplamente dos atrasos dos pagamentos [ $\mathrm{D}$. Manuel proibia que se tirasse do dinheiro destinado à compra de especiarias para pagar os salários atrasados dos soldados que trabalhavam nas fortalezas portuguesas em Índia] Tão ardentemente desejavam ir às presas, que se recusavam a entrar nos portos para impedir que os árabes comprassem pimenta, dizendo que melhor seria que se esperassem as naus à saída, porque já viriam carregadas. Verdadeiro raciocínio de piratas, como se vê! (CHAGAS, AJVR, [1890] s.d, p.100103).

D. Manuel legitimava essas ações dos portugueses quando permitia que as mercadorias apreendidas dos árabes fossem enviadas a Portugal e lá vendidas por toda a Europa. Além de incentivar uma imagem sórdida do português em Índia, não era desejo de a realeza promover nesses espaços estratégias de povoamento e de infra-estruturas.

A maneira irresponsável e incompetente com que os reis se ocuparam das questões coloniais é, para Pinheiro Chagas, o início do fim da nação portuguesa. De toda a história nacional, três períodos lhe pareceram cruciais para suas perdas: o período manuelino, o de D. João III e a dinastia Filipina, depois da morte de D. Sebastião, que não deixou sucessores ao trono.

Em A conspiração de Pernambuco, que remonta a invasão holandesa no Brasil, Chagas estabelece novamente comentários sobre os prejuízos que tivera Portugal quando era unificado à Espanha na Dinastia Filipina.

Quando a metrópole assim se deixara surpreender, o que faziam as colônias? Em parte nenhuma houve o mínimo sintoma de resistência. O Brasil aceitou, como todas as outras possessões, a decisão do reino, e o leão espanhol pousou a garra aberta nas três quartas partes do mundo. [...] A fatalidade decididamente pesava sobre nós. Vítimas tínhamos sido da indiferença, com que a Europa assistira ao aumento da monarquia das Espanhas, vítimas íamos ser do receio que esse desenvolvimento afinal inspirava na Europa. Da primeira vez tínhamos perdido a independência, da segunda vez íamos perder as colônias. Quando a última hora de um povo 
soa no relógio da Providência, tudo conspira para lhe acelerar a perda (CHAGAS, ACP, [1866] 1870, p. 20-21).

Apesar de estarem unificados nessa época, Chagas considerava que isso não queria dizer que houvesse um espírito de unidade entre Portugal e Espanha. Pelo contrário, a “ [...] falta de acordos, ciúmes, rivalidades, ódios recíprocos e todas as consequências funestas que resultam na guerra desses vícios de organização” (IDEM, p.33) impediram que esses dois países formassem um só corpo nacional. Mas este autor não considera as invasões, que sofreram as possessões portuguesas, como uma consequência do ódio espanhol a Portugal, mas sim da falta de organização da monarquia espanhola, uma vez que nesse mesmo período importantes colônias castelhanas foram também invadidas pelos ingleses e holandeses ${ }^{72}$.

Depois de sessenta anos de poderio filipino, inicia-se a Dinastia de Bragança, com o reinado de D. João IV. Sob os ares da Restauração, esperava-se um novo comportamento real, sem a intervenção dos jesuítas, mas o que se viu era Portugal ainda aprisionado nos preceitos religiosos. D. João IV figura em dois romances de Pinheiro Chagas (A máscara vermelha e $O$ juramento da Duquesa) como um rei indiferente aos destinos da nação, que permite ainda a presença dos jesuítas no período de reconstrução da nacionalidade. Apesar de, às vezes, D. João IV demonstrar certa sensatez nas pequenas decisões, Chagas o retrata como um homem rancoroso nas punições aos conspiradores, inepto e apático em se tratando de assuntos nacionais.

[...] D. João IV foi avisado em Vila Viçosa de que fora proclamado rei, como veio para Lisboa e aqui foi recebido com um entusiasmo que ele não merecia, [...].

D. João IV era completamente incapaz de suprir essa falta de homens habilitados. Se tinha um bom senso natural que o tornava próprio para seguir entre as diferentes medidas, que lhe eram apresentadas, a mais curial e a mais útil, não tinha inteligência nem conhecimento de negócios bastante para tomar a iniciativa na administração. [...] (CHAGAS, AMV, [1873] s.d, p.82-83)

A partir de então as sucessões dos monarcas são cada vez piores, degenerando a linhagem e a nação. O sucessor de D. João IV, D. Afonso VI (A mantilha de Beatriz) ${ }^{73}$ é

\footnotetext{
${ }^{72}$ Ver Chagas, ACP, [1866] 1870, p.28. Esse autor cita parte das Antilhas, precisamente a Jamaica, que fora invadida pelos ingleses e a Guiana pelos holandeses.

${ }^{73}$ Ver Chagas, UEC, s.d. Um enredo a Cálderon é uma novela histórica publicada juntamente no mesmo volume de O naufrágio do Vicente Sodré. Nesta narrativa, aparece D. Afonso VI governando, mas as aventuras descritas são as do seu irmão, D. Pedro II. Esta figura histórica é descrita como uma pessoa ciumenta, impetuosa e
} 
descrito como um monarca fraco, de temperamento instável e colérico. Demonstrando ser indiferente aos problemas de Portugal. Pinheiro Chagas considera que este tenha sido um dos piores momentos enfrentados pela nação, que acaba por retroceder. Contudo, não só a incapacidade do rei em governar realçou esse período de declínio como os constantes conflitos com a Espanha, que ameaçava a independência portuguesa, evidenciaram a vulnerabilidade de Portugal. Seu governo também demonstrou não se preocupar na manutenção das conquistas ultramarinas. No ano de 1662, Bombaim é presenteada como dote ao rei de Inglaterra pelo seu casamento com a princesa Catarina. Sobre este fato, Chagas não deixa de se lamentar e condenar a postura fradesca com que os reis portugueses conduziram suas relações internacionais. E, para dar mais ênfase à matéria, quem comenta sobre o episódio é o implacável Marquês de Pombal ${ }^{74}$, em O terremoto de Lisboa.

Pergunte aos espanhóis, que por nosso mal aqui dominaram sessenta anos, quem lhes arrancou das mãos as colônias? A companhia holandesa. Olhe para a Índia e veja quem domina por lá os sítios onde outrora tremulava a bandeira de Portugal? A companhia Inglesa. Ah! são muito inteligentes estes senhores e de uma instrução raríssima! Ora! Educaram-nos os jesuítas e é o que basta (CHAGAS, OTL, 1874, p.102).

Na trama, a personalidade enérgica e astuta de Pombal exerce muita ascendência sobre o espírito passivo e influenciável de D. José. Na opinião de Chagas, o reinado deste monarca, apesar das medidas de austeridade de seu primeiro-ministro, ilustra um dos períodos de maior crescimento nacional. “ Esse decreto [o da nomeação do Marquês de Pombal como primeiro-

\footnotetext{
inescrupulosa, que trama todo tipo de intriga para evitar que Dona Violante de Sousa, uma personagem inventada, pudesse se casar com o alferes D. Rodrigo. O impedimento do amor entre os dois deixava livre o caminho para as investidas lascivas do príncipe.

${ }^{74}$ Ver Chagas, OTL, 1874, p.111. As imagens do Marquês de Pombal ou Sebastião José de Carvalho e Mello que podem ser encontradas em $O$ terremoto de Lisboa são de um homem enérgico e perspicaz que consegue reerguer Portugal depois do fatídico terremoto de 1755, mesmo que ele não tenha se utilizado de meios pouco éticos com a maioria das pessoas, principalmente com os adversários. "Lord Tirawley olhou com assombro para a fisionomia tranquila de Sebastião de Carvalho. Em que se fiava aquele homem que assim respondia com tanta segurança? Olhou para Diogo de Mendonça [ secretário dos negócios da marinha e ultramar], e viu-o pálido e trêmulo [depois que Pombal recusa a atender as exigências do cônsul inglês de evitar que dois oficiais da marinha britânica fossem julgados pela corte portuguesa], como se já tivesse diante de si, a luzirem ao sol brilhante de Portugal, as cem baionetas com que lord Tirawley nos ameaçava. Aqueles dois homens representavam duas fases bem distintas da existência de Portugal. Um era o velho Portugal, mísero, humilhado, tal como D. João V o legou a seu filho, o outro era o novo Portugal, o rejuvenescido Portugal, tal como ele ia sair das mãos desse potente obreiro, enérgico, forte respeitado, não sofrendo humilhações, e respirando com entusiasmo o cheiro inebriante da pólvora.” Segundo Oliveira Martins, esses benefícios que tinham somente a coroa inglesa vinha desde o reinado de D. João IV firmou o tratado de 42 em que " [...] fazia de cada inglês um rei de Portugal; deu-se a esses insulares ativos, a faculdade de comerciar livremente em Portugal com a Índia, com a África e com o Brasil. Os portugueses não poderiam fretar navios de outras nações enquanto houvesse no porto navios ingleses - nenhum inglês poderia ser preso, sem permissão do seu juiz conservador - e as mercadorias inglesas nunca poderiam na alfândega portuguesa mais de $23 \%$ ad valorem, sob quaisquer títulos." (MARTINS, [18? ] 1951, p.155).
} 
ministro], que el-rei D. José assinava com indiferente complacência, ia iluminar de glória imortal o seu reinado, ia torná-lo uma das épocas mais brilhantes da história portuguesa” (IDEM, p.21).

Mas nenhum outro monarca foi tão criticado por Pinheiro Chagas como o pai de D. José, D. João V, que é pintado com tanta comicidade que em algumas passagens a atuação desse monarca beira ao ridículo em A corte de D. João $V$, principalmente nas cenas em que o este tenta seduzir a Condessa de San Pablo. Nesse romance histórico, o narrador enfatiza sempre que possível a frivolidade desse monarca pelos gastos excessivos empregados na construção de obras que não tinham nenhuma utilidade pública a não ser como símbolo de ostentação. Chagas o descreve ridiculamente como um rei de posturas fradescas, egoístas e perdulárias.

Entre todas as loucas prodigalidades de D. João V é talvez esta a menos conhecida, e ao mesmo tempo a mais digna de ser verberada pelo historiador imparcial. [...] dispender a quantia de um milhão de cruzados num palácio construído com o propósito único de servir de estalagem à comitiva real nesta jornada [palácio de Vendas Novas], é a prova mais evidente dessa vaidosa magnificência, desse fausto estéril, egoísta e inútil, que, a meu ver, caracterizam todas as obras empreendidas por este monarca. Nisto mesmo se faz sentir a mania de parodia Luís XIV, que tanto preocupava o rei fidelíssimo. [...] Que atividade tão mal empregada! Que zelo e energia tão desaproveitados! Onde há aí um verdadeiro português, um português de coração e de juízo, que não verta lágrimas de sangue ao pensar no que um rei verdadeiramente civilizador podia fazer deste desgraçado país com os homens e recursos de que então dispunha! [foi no reinado de D. João $\mathrm{V}$ que houve a maior extração de metais preciosos nas colônias] Tudo empregado em frivolidades! E a tola vaidade do sr. D. João $\mathrm{V}$ era acariciada suavemente quando o abade espanhol Mongone, estupefato ao saber que em tão pouco tempo se tinha terminado tamanha obra, e se tinham vencido tamanhas dificuldades, exclamou: El Rey de Portugal añade a su grandeza la de hacer milagros! Milagres fazia-os, sim! Mas em vez de ressucitar o Lázaro imenso, que morria esfaimado em torno do esplêndido festim da realeza, ainda mais lhe esmagava o cadáver, assentando montanhas de mármore em cima da lousa do seu túmulo! (CHAGAS, ACDJV, [1867] 2002, p.41, grifo do autor).

A Dinastia de Bragança é o período histórico que Chagas mais se utiliza para compor seus romances históricos. Nesse sentido, parece-nos que ele também compreendeu, como Oliveira Martins, que “ [...] Portugal [foi] o baluarte da companhia e a Dinastia de Bragança, obra dela, foi o seu melhor pupilo” (MARTINS, [18?] 1951, p.101). Apesar da descendência da 
casa brigantina começar em Nuno Álvares Pereira ${ }^{75}$, considerado como um herói e um santo por Oliveira Martins e como um Aquiles português, por Chagas - ela não consegue honrar as qualidades do seu patriarca. Martins conclui afinal que a Casa de Bragança teria sido “ [...] uma sucessão de intrigantes mesquinhos, de maus doidos, ou de egoístas vulgares” (MARTINS, [18?] 1951, p.136), que colocaram a perder Portugal e suas possessões coloniais.

Já comentamos como a maneira inconsequente de D. Sebastião colocou em risco o destino da nação. Instituindo, a partir daí, como esclarece Oliveira Martins ([18?] 1951), o sebastianismo na alma nacional, essencialmente fradesca e passiva, que confiava no retorno do salvador da pátria.

[...] O povo, abandonado e perdido, abraçava-se à natureza, fazendo do lendário D. Sebastião um gênio, um espírito - e da sua história um mito.

O sebastianismo era pois uma explosão simples da desesperança, uma manifestação do gênio natural íntimo da raça, e uma abdicação da história. Portugal renegava, por um mito, a realidade; morria para a história, desfeito num sonho; envolvia-se, para entrar no sepulcro, na mortalha de uma esperança messiânica (MARTINS, [18?] 1951, p. 93, grifo nosso).

Compartilhando dessa ideia martiniana acerca da desorientação que ocorre na população, que se vê desprotegida sem o pai-nação, Pinheiro Chagas argumenta que: "Faltou rei [aludindo a morte de D. Sebastião], faltou tudo, porque o povo nem já sabia de si, e as cortes, quando não havia quem mandasse alguma coisa, nem sabiam o que haviam de fazer" (CHAGAS, HAP, [1878] s.d., p.98).

Mas o povo se viu abandonado novamente em outra situação mais ultrajante, que foi a saída de D. João VI às pressas, pressionado tanto pelas tropas napoleônicas como pelos conselhos suspeitosos do governo inglês. O livro Os guerrilheiros da morte reconstitui a fuga da família real de Portugal em meio ao tumulto da multidão, que os queria impedir. Nos momentos que antecederam o fatídico episódio, D. João VI é retratado como um monarca assustado, covarde, beato, burlão e simpatizante da Inglaterra ${ }^{76}$. O herói desse romance, o

\footnotetext{
${ }^{75}$ Ver Chagas, 1873, p.18-20. “É o mais brioso paladino da nossa história, e um dos mais notáveis guerreiros de Portugal. [...] Valente, ninguém o foi mais; de lealdade, era um modelo; austero nos costumes, religioso, a todos dava o exemplo de piedade e da moralidade. [...] Era verdadeiramente uma figura épica a do Condestável, mas tinha no caráter a bondosa mansidão dos fortes.”

${ }^{76}$ Cf. Martins, [18?] 1951, p.283-284. Oliveira Martins considera que D. João VI reuniria todos os vícios de seus descendentes juntos. “ Neste derradeiro representante do sangue bragantino [este autor afirma que os filhos de D. João VI teriam antes o sangue da mãe, e os reis posteriores sangue alemão] apareciam vivos todos os caracteres da raça. Era necessário que, ao extinguir-se, a árvore desse o mais bem acabado fruto. Egoísta e seco como D.João IV, tinha inclinações fradescas como D. João V; tinha a esperteza soez e baixa de D. Pedro II, e o
} 
sargento de polícia Jaime Cordeiro de Altavilla, aparece pela primeira vez lendo o decreto do anúncio do traslado real para o Brasil. Eram do conhecimento geral as interferências da Inglaterra nas decisões governamentais, e quando Jaime leu que o monarca se justificava como um risco à nação não conseguiu conter a sua ironia.

O príncipe regente declarava que movido pelo receio de atrair sobre os seus fieis súditos com a sua presença maior calamidade partia para a América, onde se ia estabelecer no Rio de Janeiro até a paz geral.

- Aliado dos ingleses na América, e dos franceses na Europa, é boa ideia! Os franceses já o expulsaram da Europa; Deus queira que os ingleses o não expulsem da América (CHAGAS, OGM, [1872] 1874, p.68, grifo nosso).

O trecho em destaque parece visionar uma situação que será tratada pela História como o último ato de uma nação moribunda, o Ultimatum inglês. Se a lambança promovida por D. João VI com a sua infeliz aliança com Inglaterra não conseguiu efetivar a morte definitiva de Portugal, tempos depois, isto se tornava inevitável quando D. Carlos, o último monarca da Casa de Bragança, assina o tratado de retirada dos portugueses de África.

Ao que parece, Chagas defende que, embora o país dependesse todo tempo das riquezas coloniais, pois não produzia o seu próprio sustento, o Estado nunca assumiu essa dependência. Pelo contrário, seus dirigentes se mantinham indiferentes à necessidade de políticas que salvaguardassem esses territórios. Este descaso não era novidade, vinha ocorrendo desde o período dos descobrimentos no reinado de D. Manuel. E, como já indicamos, a temática colonial parece permear as discussões desde os primeiros romances no gênero de Pinheiro Chagas. Como exemplo, há o episódio em Os guerrilheiros da morte, em que a personagem histórica D. Rodrigo Coutinho, secretário da pasta da Marinha e do Ultramar, alerta D. João VI sobre o grande erro que era ceder às exigências francesas, saindo de Portugal sem o menor combate.

- Mas, meu senhor, acudiu D. Rodrigo Coutinho aproveitando o ensejo, vossa alteza acaba de mostrar, com a sua perspicácia, o caminho que temos a seguir [fazer resistência à França, mesmo com uma frota em menor número]. Somos uma nação essencialmente marítima e colonial, a França, que não pode proteger as suas colônias, muito menos poderá proteger as nossas [a História se repetia como acontecera no período da União Ibérica

plebeísmo de Afonso VI, sem ser inteiramente idiota, como fora o infeliz encarcerado de Cintra. Todas estas qualidades, e por isso mesmo que as reunia todas, apareciam em D. João VI esbatidas e confundidas, sem nenhuma predominar, realizando assim um tipo complexo, merecedor dos louvores de alguns, igualmente digno do enjoo de muitos.” 
com as várias invasões que ocorreram na américa e no oriente]. E o que seremos nós sem o Brasil! Ponha vossa alteza os olhos na Holanda. Veja os males, que lhe resultaram da sua íntima conexão com a França. Está perdido o seu vasto império ultramarino. Suceder-nos-ia o mesmo, meu senhor. E, com todas essas humilhações, vossa alteza não conseguiria salvar a coroa de sua augusta mãe (IDEM, p.47-48).

Mas o fato de Pinheiro Chagas optar pela dramatização desse período da História nacional nos seus romances históricos de terceira fase segue uma tendência literária da época impulsionada pelo sentimento de comoção nacional provocada pelo Ultimatum inglês ${ }^{77}$. De acordo com Maria Teresa Pinto Coelho (1996), este episódio conseguira que, independente de suas concepções ideológicas, literárias ou políticas, todos discutissem sobre o assunto. Sob este aspecto, “ O Ultimatum consegue, pois, agregar, pelo menos temporariamente, os sentimentos nacionalistas de ultrarromânticos, realistas, simbolistas e decadentistas, assim como Progressistas, Regeneradores e Republicanos” (COELHO, 1996, p. 267). Outro ponto interessante de sua conclusão é considerar que o sentimento de revolta foi uniforme, mas nem todos previram o fato como inevitável.

Mas desse grupo de intelectuais que discutiram e, acima de tudo, anteciparam uma catástrofe advinda dos equívocos cometidos por Portugal em relação a suas colônias, poderíamos incluir Pinheiro Chagas certamente. Em sua opinião, o período manuelino é o início da má governabilidade de seus reis, que insistiam numa política colonial de exploração. Nos romances históricos da última fase, seu autor salienta as relações desastrosas que os portugueses estabeleceram na Índia, alimentando o ódio dos nativos. A antipatia aos

\footnotetext{
${ }^{77}$ Ver Chagas, ACPS, 1890, Cap. X, p.217-221. Relembrando os antecedentes desse trágico episódio. Desde 1886, Portugal vinha se resguardando sobre possíveis perdas coloniais em território africano. Para isso, resolveu celebrar alguns tratados de limites com a Alemanha e França, que reconheceram suas possessões em África, mas em troca exigiram outros territórios. Por outro lado, a Inglaterra avançava as fronteiras coloniais demarcadas por Portugal, que havia abandonado as políticas de exploração colonial. Foi nesse momento então que julgaram prudente retomar esses projetos e enviaram expedições de ocupação e desenvolvimento. Uma dessas promoções era comandada por Serpa Pinto que pretendia ligar pelos caminhos de ferro Angola a Moçambique, território cuja extensão havia sido incluída no Mapa Cor de Rosa, depois da Conferência de Berlim, mas que a Inglaterra não reconhecia como sendo de Portugal. No final de 1889, ocorreria o pretexto que desencadearia a ira inglesa. Serpa Pinto, ao passar perto do rio Chire, deparou-se com a tribo Macololos, que proibiam a sua passagem em respeito a aliança com os ingleses. Pinto não titubeou e enfrentou implacavelmente os africanos, derrotando-os. Ao tomar conhecimento sobre o acontecimento, a Inglaterra protesta com veemência contra as ações do major português e exige a sua retirada para o sul de Ruo. Portugal, sempre se esquivando das pressões inglesas, irrita a coroa britânica. E no dia 11 de janeiro de 1890, esta assume uma medida extrema, ameaça por meio de um memorando retirar sua embaixada de Lisboa, além de pressionar militarmente com suas esquadras os litorais de Cabo Verde e Moçambique. O desfecho de mais esse episódio trágico da História nacional se dá com o governo de D. Carlos I cedendo às exigências de Inglaterra na assinatura do tratado, apesar do forte apelo da nação, que permanecia contrária. Tanto para os leigos quanto para a intelectualidade portuguesa, essa ação foi a mais degradante que a pátria sofrera em toda a sua História. Considerado por muitos historiadores como o tiro de misericórdia de uma nação que agonizava há tempos.
} 
portugueses, mais tarde, incentivaria as alianças indianas com as coroas de França, Holanda e Inglaterra.

Foi Portugal o primeiro povo europeu que teve possessões na Índia, porque foi o primeiro também que encontrou o caminho marítimo do Oriente. [...] O prestígio das nossas armas tornou-nos respeitados, e o nosso comércio foi se ampliando, até que el-rei D. Manuel entendeu que devia ter no Oriente um representante do seu poder, que dirigisse os portugueses dispersos por essas remotas partes. Nomeou em 1503, vice-rei D. Francisco de Almeida, que entendia que Portugal devia conservar o império do mar, para proteger o seu comércio, mas que não devia fundar estabelecimentos. [...] O seu sucessor, Afonso de Albuquerque seguiu um sistema diverso, e tinha razão também, se os seus sucessores soubessem seguir os seus exemplos e compreender a sua política. Esse lançou as bases de um poderoso império luso indiano, mais perdurável do que o moderno império anglo-indiano, porque se fundava na união íntima dos vencedores e vencidos. [...] Os seus sucessores foram ampliando o império, mas não souberam como ele conciliar a estima e a simpatia dos índios. [...] [ por outro lado] a corrupção ia penetrando nas nossas fileiras. [...] O começo do domínio espanhol foi o sinal da nossa ruína, em primeiro lugar pela pouca atenção com que o governo intruso tratava as nossas possessões, em segundo lugar, porque os holandeses e os ingleses, em guerra com a Espanha, começaram a juntar-se aos indígenas para demolir o novo império, Málaca, Ormuz, Cochim, a ilha de Ceilão, as Molucas, quase todas as nossas praças foram caindo sucessivamente nas mãos da Holanda, ou voltaram aos seus naturais soberanos. No fim do século XVII estava já reduzidíssimo o nosso domínio. A doação de Bombaim aos ingleses em 1662 [como dote do casamento da princesa Catarina, filha de D. João IV], as guerras com Sevadji, o soberano de Mahrata, contribuíram mais para o desmoronamento. No século XVIII, o governo do marquês de Alorna assinalou-se pelas conquista de alguns territórios, hoje conhecidos pelo nome de Novas Conquistas, mas, como entretanto ia crescendo ao nosso lado o colosso anglo-indiano, não tardamos a ficar reduzidos ao que hoje temos - uma língua de terreno de pouco valor comercial e agrícola, conservado como relíquia das nossas velhas glórias, e que a tolerância inglesa nos deixa (CHAGAS, DP, 1880, p.339).

Dessa maneira, os romances de terceira fase reconstituem o período da expansão marítima sob uma perspectiva negativa do português em solo colonial. Reconstruindo a origem de uma morte nacional que culminará com o Ultimatum. Este ato final seria, portanto, o reflexo das ações irresponsáveis de uma geração podre de reis egoístas e loucos, que iam barganhando, doando e vendendo o sustento da nação aos pretensos aliados.

Demonstradas as proposições que fundamentam as escolhas dos períodos históricos para seus romances, expliquemos agora o porquê do romance histórico, dentre os vários gêneros praticados por ele, ter sido, juntamente com o teatro, uma preferência de criação. Como já deve ter ficado claro, o romance histórico, diferente do realista que aborda os costumes da 
atualidade, vai depender, para a reconstrução da época que escolheu retratar, de documentos que possam informar tais peculiaridades. Fora isso, ambos tem como leitmotiv o comportamento humano.

Vejamos isso, então, em uma comparação de ordem temática e estrutural entre $A$ virgem Guaraciaba (1865), o primeiro romance de Pinheiro Chagas, e O crime do padre Amaro, de Eça de Queirós, inaugurando o realismo em Portugal no ano de 1874.

Como tema, ambos discutem o anticlericalismo, a hipocrisia e o egoísmo do clero, que estavam a serviço de seus interesses, e nunca de suas comunidades. Nas duas tramas, temos duas meninas que educadas sob o catolicismo extremado são objetos nas mãos de religiosos que tinham certa importância em suas vidas. Beatriz, a heroína de Pinheiro Chagas é agenciada na conversão de Caetéguara. Amélia, sob a influência de Pe. Amaro, é seduzida, servindo ao seu propósito egoísta e lascivo, até o momento em que ela passa a ser uma ameaça à perda da batina, e com esta todas as honras advindas dela. Duas mulheres que foram destruídas pela inocente e romantizada postura que tiveram diante da astúcia de um clero sem escrúpulos.

Já nos aspectos estruturais das intrigas, as duas narrativas são conduzidas por um narrador extradiegético e heterodiegético, tendo como protagonistas personagens inventadas, inseridas em um ambiente simulacro da realidade, em que agem realisticamente na intriga. Contudo, é claro que as diferenças surgem quando se trata das descrições desses costumes, por exemplo, a narrativa do tempo recuado não provoca tanta estranheza aos olhos do leitor, pois se tratavam de hábitos distintos dos dele e do autor. Já no romance eciano, a vida devota denunciada e satirizada, possivelmente, dever ter causado indignação aos fiéis.

Mas há um último aspecto imprescindível à existência do romance histórico, que no romance de costumes do presente não é tão explícito o seu uso, a legitimação dos relatos. No romance histórico, a todo instante, o narrador tenta convencer o leitor que aquilo que ele conta é puramente verossímil, pelo distanciamento que existe entre o tempo passado do narrado e o presente do leitor. Estratégia que não faz muito sentido numa narrativa que remete a assuntos contemporâneos.

Pelas abordagens que fizemos, parece que o autor de A virgem Guaraciaba deve ter elegido o romance histórico, pois este poderia concorrer por um espaço com o romance realista/naturalista no território cultural português, já que ambos eram romances de costumes, diferenciando-se apenas nos espaços escolhidos para desenvolverem as suas tramas, um optando pelo passado e o outro pelo presente. 
Assim, o seu estudo histórico romântico nasce da insatisfação do público diante da efabulação desmedida do factual. Como ponto de atração para o novo gênero, seu autor deixa claro que sua proposta é desvendar a vida privada das personagens referenciais, fatos que a História omitiu pelo seu caráter específico.

A velha fórmula do romance histórico está decididamente fora do gosto público, mas a curiosidade de ver os personagens históricos apeados do seu pedestal, e movendo-se nas peripécias da vida comum, é cada vez mais intensa. O que se não tolera é que a imaginação do romancista procure inventar personagens que se misturam, eles são filhos da fantasia, com os personagens reais, e ainda mais, atribuir a estes últimos pensamentos, planos, objetivos que eles nunca tiveram, e que são muitas vezes absolutamente contrários ao papel que representaram na cena verdadeira da história (CHAGAS, ONVS, [1892] 1910, p.5-6)

Para alcançar estes propósitos, era preciso que o romancista histórico mantivesse um rigor na composição da ficção histórica, não menosprezando nem o caráter histórico nem aqueles pertencentes à imaginação do autor, que organiza os fatos do passado na intriga do romance. Na concepção de Pinheiro Chagas, para se conseguir isso, o escritor deveria:

a) Não procurar o drama fora da realidade;

b) Não inventar episódios, nem fantasiar personagens;

c) Orientar-se pelas cenas tais como a história descreve;

d) Compreender a essência histórica dos personagens, revelados pelos seus atos;

e) Adquirir duas faculdades: a do observador e a do encenador. Só assim, poderia interpretar o fato histórico e dramatizá-lo de maneira que o leitor entendesse o espírito de uma época, ou seja, didaticamente. O romancista histórico seria o mediador entre o conhecimento histórico e o leitor;

f) Valorizar as memórias como uma fonte importante pelo seu caráter realístico, detalhado e particular da época. Contudo, deve-se, antes de tudo, analisar a base política do memorialista, para não incorrer nos desacertos com a História. Além disso, é necessário estabelecer uma devida distância sobre esses relatos, que não deixam de estarem contaminados pelas paixões políticas de quem os escreve.

g) Preservar qualidades do contador de histórias: contar bem numa linguagem fluente, num estilo suave e agradável. O romancista deve ter o compromisso de entreter o leitor de maneira, que mantenha a sua curiosidade e atenção. 
Como se pode ver, os critérios estéticos de Pinheiro Chagas, na feitura do romance histórico, orientam-se pela seguinte tríade: investigação histórica, unidade dramática e verossimilhança da época e na construção de personagens. A partir desses elementos se poderia compor uma história coerente, em que figuras inventadas e vultos históricos atuassem no ficcional, criando uma “ $[. .$.$] perfeita reprodução do viver e crer daquela época. O$ episódio histórico, que serve de pretexto à evocação dos homens e dos costumes desse tempo, vem narrado com vivas cores e é posto em cena com perfeição dramática [...]” ( CHAGAS, EC, [1866] s.d, p.63, grifo nosso).

O elemento dramático seria, portanto, algo que dá unidade à trama, na concepção de Chagas. Essas estratégias seriam, primeiramente, menos narrações e mais atuações das personagens, alcançadas pelos elementos cênicos, tais como, breves notações do narrador sobre a cena e a brevidade dos diálogos. A dramaticidade do episódio daria mais movimento, rapidez e emoção à narrativa. Um desses exemplos de sucessão de acontecimentos pode ser comprovado pelo trecho que recortamos do romance A mantilha de Beatriz, em que o herói Francisco de Mendonça duela com seu opositor debaixo da janela de Beatriz, em decorrência de uma rusga que tiveram no passado.

Emudeceram todos e, no meio deste silêncio, percebeu-se distintamente a voz de Francisco de Mendonça a bradar:

- Defende-te, covarde! assassino!

- Arredem-se! gritava ao mesmo tempo a voz de D. Estevão de Portugal, arredem-se! Deixem-se ensinar este pintalegrete!

- Não finjas dispensar o auxílio dos teus esbirros! Só à sua frente ousas manejar uma espada. Mas deixa que os não temo! Cara me comprarás a vida.

- É a voz do meu amigo! bradou Luís de Meneses.

- É a voz de ... dele! Exclamou Beatriz correndo à janela, matam-no! Socorro!

- Aqui estou, meu amigo! meu irmão! Coragem! Bradou Luís de Menezes, indo para a porta de espada em punho.

- Alto! Bradou D. Álvaro fechando a porta e metendo a chave na algibeira. não lhe disse que não saía de minha casa antes de amanhã, sr. Francisco de Mendonça? [D. Álvaro conversava nesse momento com Luís Alcoforado, mas que ele pensava ser Francisco, por isso a confusão]

- Deixe-me, senhor, estão assassinando o meu amigo! [disse Luís]

- Ao mesmo tempo pela janela aberta do quarto de Beatriz entrou uma voz distante e aflita, que bradava:

- Sr. D. Álvaro, acuda-me. Matam meu irmão. Por amor de Deus, sr. D. Álvaro! [Clara de Portugal]

- A voz de Clara! Exclamou Luís. Sr. D. Álvaro, deixe-me sair, que fico desonrado!

- Clara, o que tem com ela?

$[\ldots]$ 
- Aí vou, Clara, aí vou, aqui me tens! Gritou Luís de Meneses, correndo desvairado para o quarto de Beatriz.

- Espera, infame! Berrou D. Álvaro, correndo atrás dele, pois tu requestas as duas!

- Deixe-o ir, meu pai, deixe-o o ir, exclamava Beatriz suplicante e chorosa, acuda-lhe, peço-lhe, acuda-lhe que o matam!

[...]

- Acudo a quem? Sigo a quem? disse D. Álvaro abrindo a porta que fechara à chave.

- A Francisco de Mendonça! acudiu Inês, abrindo a janela a tempo de Luís de Menezes, saltando do muro do jardim, corria em socorro do seu amigo.

- Inferno! Exclamou D. Álvaro saindo escada abaixo de espada em punho. Vou desembrulhar às cutiladas este meada toda! (CHAGAS, AMB, 1879, p.106-107)

Neste excerto, a cena movimenta-se na intensidade das emoções das personagens, principalmente das mulheres, que agitadas pela possibilidade de um adversário matar o outro, suplicam pela intervenção de D. Álvaro no duelo, que confuso não sabe a quem socorrer. As frases curtas, às vezes entrecortadas, de maneira interrogativa ou exclamativa, ajudam nessa expressividade incisiva das personagens.

Não só nessa obra, mas desde as suas primeiras publicações no gênero, o elemento dramático é valorizado. Tanto assim que o modelo do romance histórico elegido nos escritos de maturidade, ele conceitua como história dramatizada. O estudo histórico romântico é um tipo de narrativa em que a efabulação aparece expressivamente diminuída. Juan Ignácio Ferreras considera que, nesses romances feitos quase exclusivamente de personagens históricas, quanto maior a atenção dada ao fato verdadeiro, menos ficção terá. Ou seja, menos liberdade o narrador terá para inventar na diegese.

Há, portanto, um grande paradoxo no romance histórico que poderia ser explicado da seguinte forma: quanto mais rigoroso for a densidade histórica no universo ficcional, menos liberdade de ação, menos campo romanesco terá o protagonista. De outra maneira mais incisiva - quanto mais História seja o romance menos romance será. (FERRERAS, 1997, p.73-74).

Pinheiro Chagas foi um desses romancistas que, como já explicitamos, para burlar essa problemática do romance histórico, privilegia momentos ou personagens pouco revisitados pela História oficial, como foi o caso da Duquesa de Caminha e de Pedro Bonete.

É claro que o leitor que lê um romance histórico é movido pelo desejo de descobrir e ser capaz de separar o histórico daquilo que é inventado. No entanto, mais importante que isso é analisar a função estrutural que a História desempenha na intriga romanesca. Em outras 
palavras, o ideal é conhecer como o romancista consegue enlaçar o histórico ao seu mundo inventado, como afirma Jean Louis Picoche (1978 apud INDURÁIN, 1998, p. 37). Ou como propôs Maria de Fátima Marinho, ao analisar os romances históricos de Pinheiro Chagas é necessário verificar a interferência da intriga amorosa nessas obras. Sob este parâmetro, a autora conseguiu determinar quatro grupos. Assim, permanece no primeiro somente a Corte de D. João $V$ (1867), pois, como ela sugere, o mais importante a ser ressaltado aqui é a descrição do ambiente, independente da trama. No segundo grupo, devido à efabulação da história, em que as personagens históricas ficam em segundo plano, reunidas neste espaço estão Os guerrilheiros da morte (1872), O terremoto de Lisboa (1874), As duas flores de sangue (1875), A mantilha de Beatriz (1878) e A marquesa das Índias (1890). No seguinte, fazem parte A máscara Vermelha (1873) e a sua continuação O juramento da Duquesa (1873) que, no seu parecer, configuram-se em duas tramas desenroladas em torno de episódios reais, ficando quase impossível ao leitor distinguir os personagens históricos dos ficcionais. Por fim, no quarto e último agrupamento, apresentam-se as narrativas em que há quase uma ausência de efabulação, dando especial relevo ao fato histórico em si, como é o caso da trilogia sobre o expansionismo marítimo presente n’ A joia do vice-rei (1890); A descoberta das Índias. Contada por um marinheiro (1890) e O naufrágio de Vicente Sodré (1892).

Nessa análise de Marinho (1999), não foram privilegiados os dois primeiros romances históricos de Chagas, intitulados pelo autor como Crônicas brasileiras: A virgem Guaraciaba e A conspiração de Pernambuco, ambos de 1866. Consideramos que, desde essas composições, este autor parece exercitar três tipos de modelos de romance histórico. O primeiro em que a intriga romântica sobrepõe a presença da História na trama. No segundo, percebemos que há uma inversão, a História passa ao plano narrativo central e não há (ou há poucos) elementos românticos. No terceiro tipo, desenvolve-se uma intriga amorosa de tendência calderoniana.

Assim, pensamos em dividir os seus quatorze romances históricos, determinando a sua fase e tendência de composição. Para isso, levamos em consideração a diegese mais inclinada à linha romântica ou à fórmula da História dramatizada, em que as personagens históricas ficam em primeiro plano. Ao final, obtemos o seguinte quadro de publicação. 


\begin{tabular}{|c|c|c|c|}
\hline \multirow{5}{*}{$\begin{array}{l}\text { Fase experimental ou } \\
\text { de aprendizagem } \\
(1866-1867)\end{array}$} & Romance Histórico & Ano & Concepção de romance histórico \\
\hline & $\begin{array}{ll}\text { A } & \text { virgem } \\
\text { Guaraciaba } & \end{array}$ & 1866 & $\begin{array}{l}\text { Há uma atenção maior dada à intriga } \\
\text { amorosa, apesar da mesma estar } \\
\text { relacionada a um fato histórico. } \\
\text { (modelo 1) }\end{array}$ \\
\hline & $\begin{array}{l}\text { A conspiração de } \\
\text { Pernambuco }\end{array}$ & 1866 & $\begin{array}{l}\text { Embora o personagem principal da } \\
\text { trama seja inventado e tenha um } \\
\text { desfecho romântico, muitos dos } \\
\text { capítulos desse livro demonstram o } \\
\text { exercício de uma dramatização da } \\
\text { História, encaminhando-se para o } \\
\text { estudo histórico romântico, em que } \\
\text { personagens históricas ganham mais } \\
\text { espaço. (modelo 2) }\end{array}$ \\
\hline & A corte de D. João $V$ & 1867 & $\begin{array}{l}\text { A intriga romanesca é aproximada às } \\
\text { peripécias e ao humor da novela de } \\
\text { capa e espada de Calderón. (modelo } \\
\text { 3) }\end{array}$ \\
\hline & O major Napoleão & 1867 & $\begin{array}{l}\text { Aproximada ao modelo } \mathbf{2} \text { de } \\
\text { romance histórico, é uma narrativa } \\
\text { memorialista }^{78} \text {, que mistura } \\
\text { elementos românticos e góticos. }\end{array}$ \\
\hline \multirow{5}{*}{$\begin{array}{c}\text { Fase intermediária ou } \\
\text { de transição } \\
(1872-1878)\end{array}$} & $\begin{array}{l}\text { Os guerrilheiros } d a \\
\text { morte }\end{array}$ & 1872 & Modelo 2 de romance histórico. \\
\hline & A máscara vermelha & 1873 & $\begin{array}{l}\text { Modelo } 2 \text { de romance histórico. Pela } \\
\text { primeira vez, protagoniza a história } \\
\text { uma personagem histórica, apesar de } \\
\text { parecer inventada pelo leitor } \\
\text { desavisado. }\end{array}$ \\
\hline & $\begin{array}{l}\text { O Juramento da } \\
\text { Duquesa }\end{array}$ & 1873 & $\begin{array}{l}\text { Como continuação do romance } \\
\text { anterior segue o modelo } 2 \text { de } \\
\text { narrativa histórica. Embora haja um } \\
\text { fio condutor romântico que une as } \\
\text { partes da História. }\end{array}$ \\
\hline & $\begin{array}{l}\text { O terremoto de } \\
\text { Lisboa }\end{array}$ & 1874 & $\begin{array}{l}\text { Ainda que o título remeta a um } \\
\text { acontecimento histórico, este livro } \\
\text { segue ao modelo } \mathbf{1} \text { de romance } \\
\text { histórico. }\end{array}$ \\
\hline & $\begin{array}{l}\text { As duas flores de } \\
\text { sangue }\end{array}$ & 1875 & $\begin{array}{l}\text { Mais aproximada do modelo } 2 \text { de } \\
\text { romance histórico. Apesar do herói } \\
\text { da trama ser inventado, ele se } \\
\text { envolve amorosamente com duas } \\
\text { personagens históricas vítimas da } \\
\text { revolução francesa: Princesa de }\end{array}$ \\
\hline
\end{tabular}

\footnotetext{
${ }^{78}$ Pinheiro Chagas retoma este tipo de romance histórico memorialista com o marinheiro Bastião Fernandes em $A$ descoberta das Índias. contada por um marinheiro.
} 


\begin{tabular}{|c|c|c|c|}
\hline & & & Lamballe e Leonor Pimentel. \\
\hline & $\begin{array}{l}\text { A mantilha de } \\
\text { Beatriz }\end{array}$ & 1878 & $\begin{array}{l}\text { Narrativa que segue o estilo do teatro } \\
\text { de Calderón. Modelo } 3 \text { de romance } \\
\text { histórico. }\end{array}$ \\
\hline \multirow[t]{4}{*}{$\begin{array}{c}\text { Fase de maturidade } \\
(1890-1892)\end{array}$} & $\begin{array}{l}\text { A marquesa das } \\
\text { Índias }\end{array}$ & 1890 & Modelo 3 de romance histórico. \\
\hline & A joia do Vice-rei & 1890 & $\begin{array}{l}\text { Modelo } 2 \text { de romance histórico, em } \\
\text { ainda há a presença de ingredientes } \\
\text { românticos de maneira mesmo que } \\
\text { superficial em pelo menos duas } \\
\text { situações envolvendo Lourenço, a } \\
\text { primeira com sua prima e a outra } \\
\text { com uma filha do xeique indiano. }\end{array}$ \\
\hline & $\begin{array}{l}\text { A descoberta das } \\
\text { Índias. contada por } \\
\text { um marinheiro }\end{array}$ & 1890 & $\begin{array}{l}\text { Narrativa protagonizada por uma } \\
\text { personagem inventada, mas } \\
\text { caracterizada como estudo histórico } \\
\text { romântico, perfazendo um dos livros } \\
\text { da trilogia que relata as aventuras e } \\
\text { intervenções dos portugueses no } \\
\text { expansionismo marítimo. Modelo } 2 \\
\text { de romance histórico. }\end{array}$ \\
\hline & $\begin{array}{l}\text { O naufrágio } \\
\text { Vicente Sodré }\end{array}$ & 1892 & $\begin{array}{l}\text { Modelo } 2 \text { de romance histórico, as } \\
\text { personagens históricas estão em } \\
\text { primeiro plano. Não há intriga } \\
\text { romântica. }\end{array}$ \\
\hline
\end{tabular}

Esta predileção pela História dramatizada é sinalizada pela primeira vez em $A$ conspiração de Pernambuco ${ }^{79}$, quando seu autor confere importância aos episódios e personagens referenciais, colocando-os no primeiro plano do seu enredo, apesar do herói da narrativa, Rodrigo Teixeira, ser um personagem inventado. No entanto, parece ser ainda incipiente a concepção do novo modelo, se levarmos em conta a estrutura narratológica deste livro.

\footnotetext{
${ }^{79}$ Rodrigo Teixeira, nacionalista extremado e católico fanático, pede a benção a Pe. Vieira, que tenta dissuadi-lo de assassinar o governador geral de Pernambuco, Maurício de Nassau, em nome da pátria e da religião. No momento em que investe contra a vida de Nassau, como os argumentos do jovem patriota são incoerentes, logo o hábil e inteligente Nassau convence Teixeira da sua atitude insana. Envergonhado, coloca-se a serviço do governador, e a partir de então, deve-lhe lealdade. Neste tempo, restaura-se a independência de Portugal, e começa um movimento em prol da recuperação da Bahia, que era então governada pelos holandeses. Depois que Nassau retorna à Holanda, João Fernandes Vieira, político e astuto estrategista, vê a possibilidade de convencer Rodrigo Teixeira a aliar-se à causa da reintegração de posse da Bahia, como infiltrado no meio holandês. Estoura a conspiração, e Rodrigo termina liderando anonimamente um grupo que salva os insurgentes da morte. A maior parte da trama gira em torno do ideal revolucionário dos portugueses-baianos que lutavam para se tornarem livres do governo de Holanda.
} 
Na primeira parte, por exemplo, a Introdução histórica foi estrategicamente separada do corpo ficcional, funcionando apenas como notas informativas sobre o período da restauração da independência de Portugal ${ }^{80}$ só que na perspectiva portuguesa em terras coloniais. Nos oito capítulos seguintes, o romancista, na recriação ficcional do passado, ensaia seus primeiros passos no modelo da história posta em ação ${ }^{81}$. Seguindo o amadurecimento de sua tese na arte de narrar, discutida principalmente em seus prefácios, Pinheiro Chagas na quarta edição de Os guerrilheiros da morte $(1872)^{82}$ publica um prólogo com valiosas informações sobre o a maneira ideal de romancear o passado. Aqui, o autor justifica o sucesso expressivo que conseguiu, perfazendo a marca de quatro edições em um ano, devido ao crescente interesse por partes dos leitores de um tipo de romance histórico que preservasse a ilusória referencialidade histórica.

[...] o público está longe de se deixar cativar, tanto quanto se imagina, pelas grandes máquinas francesas, e que, se lê avidamente os livros de Ponson du Terrail, as aventuras do fantástico Rocambole e as histórias ainda mais fantásticas da adulterada mocidade de Henrique IV [de autoria de Alexandre Dumas], é porque não se encontra livros portugueses, que lhe ponham em ação, debaixo dessa forma dramática, tão poderosa sobre a alma popular, as cenas mais comoventes ou mais sublimes da nossa história tão fértil em grandes acontecimentos.

Eu suponho que o mérito único dos Guerrilheiros da morte, o que verdadeiramente cativou a atenção e a benevolência do público, está na dramatização das muitas cenas históricas que abundam o livro. (CHAGAS, GM, [1872] 1874, p.3-4).

\footnotetext{
${ }^{80}$ Cf. Chagas, ACP [1866] 1870, p.50. Sabendo do tédio e desinteresse de muitos leitores quanto às introduções históricas presentes nos romances históricos, Pinheiro Chagas separa do corpo ficcional as notas explicativas da História Oficial, dizendo o seguinte: “ [...] Terminemos aqui a introdução histórica já bastante longa. Separamo-a completamente do corpo do romance, para os leitores, que por estas notícias se não interessam, a possam por de parte, entrando imediatamente no primeiro capítulo da Conspiração de Pernambuco".

${ }^{81}$ Nesta narrativa histórica, apesar de Rodrigo Teixeira ser um herói inventado, até o capítulo XII, este convive com personagens históricas como Pe. Vieira, Maurício de Nassau e João Fernandes Vieira. Uma das passagens mais interessantes aqui representadas é a dramaticidade do Sermão de Portugal contra as armas de Holanda, de Pe. Antonio Vieira, uma técnica que será retomada em $O$ juramento da duquesa em outro sermão do ilustre jesuíta, O sermão de Santo Antonio.

${ }^{82}$ Romance histórico que reconstitui o período da invasão napoleônica em Portugal e, consequentemente, a fuga da Família Real para o Brasil. Vale lembrar que este tema é um dos mais requisitados pelo romancista português que por razões de importância para elucidarmos o projeto literário deste autor quanto à revalorização da pátria, trataremos especificamente em outro espaço denominado A orfandade e o feminino. Em uma nota final faz o seguinte comentário de identificação da fonte: "Entre os livros que me serviram de base para este estudo histórico romântico, pede a gratidão que eu cite os preciosos Excertos históricos da guerra da Península do meu excelente amigo o sr. Cláudio de Chaby. É um livro abundantíssimo em notícias curiosas e até hoje ignoradas, é escrito muito agradavelmente. Este consciencioso e belo trabalho dá ao sr. Cláudio de Chaby um lugar importante em nossa literatura histórica” (CHAGAS, GM [1872] 1874, p.288). Estas considerações confirmam as nossas afirmativas de que desde muito cedo, Pinheiro Chagas vinha esboçando as primeiras tentativas no seu estudo histórico romântico.
} 
Como explicitado no excerto, Pinheiro Chagas afirma que este tipo de romance não se filiava àquela romantizada ao estilo dumasiano ${ }^{83}$, muito menos incorria nas aventuras rocambolescas à maneira de Ponson du Terrail ${ }^{84}$, que de tão fantásticas faziam ressuscitar uma personagem que teria morrido no início da trama, fossem estas necessidades autorais ou para atender as súplicas do público-ledor.

No tópico seguinte da sua discussão no prefácio da obra Os guerrilheiros da morte, seu autor não exclui o elemento romanesco, necessário ao interesse do leitor pela intriga, muito menos a unidade e a veracidade do quadro do passado desenhado pelo romancista.

O enredo inventado é um fio tenuíssimo, que apenas serve para ligar entre si a narração dos fatos verídicos. Os capítulos, que mais impressionaram os leitores, foram exatamente aqueles em que eu narrava ora as hesitações dos habitantes da Ajuda na véspera da invasão francesa, ora a fuga da família real para o Brasil, ora a marcha de Junot, ora o assassínio de Bernadim Freire de Andrade, tudo cenas tiradas da realidade e em que procurei apenas conservar severamente aos personagens e aos acontecimentos o seu caráter verdadeiro e histórico (CHAGAS, GM, [1872] 1874, p.4, grifo nosso).

Desde as primeiras produções de Chagas no gênero, percebe-se que o elemento romântico é a base da intriga, perdendo força à medida que a escritura do autor vai se consolidando no estudo histórico romântico. Assim, na composição desses romances, Chagas irá utilizar o drama em duas vertentes: a primeira no que diz respeito às técnicas dramáticas, já a segunda, na escolha de episódios históricos em que haja uma presença significativa do conflito e da tragédia humana. Ademais, não se pode afirmar que os elementos românticos estejam excluídos dessas narrativas totalmente. Se o romance histórico é o produto de uma leitura que o romancista faz do passado, então, é praticamente impossível não estarem presentes na reconstituição do mesmo a sua visão de mundo e os princípios estéticos da escola na qual ele se filia.

Como também o romance histórico pode se tornar ininteligível e inverídico sem a presença dos artifícios para-textuais. Conforme Puga (2006), estes concorrem para a sensação

\footnotetext{
${ }^{83}$ Os romances históricos de Alexandre Dumas (pai) eram uma mistura de elementos do romance-folhetim com o romance de aventuras de capa e espada em que se passavam em um período histórico. Ele priorizava, dentre estes ingredientes, antes de tudo, a intriga romanesca. Mesmo que isso pudesse prejudicar a verdade histórica.

${ }^{84}$ Esta obra, criada pelo escritor francês do período oitocentista Pierre Alexis Jonson du Terrail, pode ser considerada como romance de aventuras. Seu protagonista um ladrão aventureiro de nome Rocambole, que nos três primeiros romances da série tinha um caráter negativo, passando depois do quarto livro a ter uma imagem positiva. O termo rocambolesco é uma alusão ao protagonista, indicando algo fantástico ou inverossímil, uma das razões é a mudança de caráter brusca da personagem sem ter sido indicada por uma evolução ou mesmo ter um episódio que indicasse tal mudança.
} 
de verossimilhança e interpretação da narrativa, como introduções históricas no início de cada capítulo, prefácios, notas de rodapés e, em última instância, os títulos. Sobre estes últimos, Carlos Reis e Ana Cristina Lopes (2007) consideram que eles podem elucidar “ [...] uma categoria narrativa [personagem, ação, espaço, tempo], desde logo colocados em destaque” (REIS; LOPES, 2007, p.416), apesar de passarem despercebidos pela maioria do público. Tomando como critério esta abordagem de Reis e Lopes, os títulos dos romances históricos de Pinheiro Chagas podem ser assim organizados:

1. A virgem Guaraciaba, O major Napoleão, A mantilha de Beatriz, A joia do vice- rei ( personagem)

2. A conspiração de Pernambuco, O terremoto de Lisboa (ação e espaço)

3. A corte de D. João $V$ (personagem e espaço)

4. A descoberta das Índias. contada por um marinheiro, O naufrágio de Vicente Sodré (ação e personagem).

Apesar de os outros cinco títulos não se encaixarem prontamente na organização feita, Carlos Reis e Ana Cristina Lopes advertem que isso decorre de uma construção menos explícita, só elucidada depois da leitura da diegese. Podemos incluir à lista os outros quatro romances: Os guerrilheiros da morte, A máscara vermelha, O juramento da Duquesa e As duas flores de sangue. Já em A marquesa das Índias, o título funciona como uma ilusão, pois Dolores não é a personagem principal, e sim Catarina. Por fim, ainda sobre este assunto, vale dizer que Chagas estampa um subtítulo em apenas dois casos, em A conspiração de Pernambuco $^{85}$ e em A descoberta das Índias. contada por um marinheiro. Neste, ele parece esclarecer que um período tão conhecido da nação seria por ele contado numa perspectiva mais popular, diferente da convencional encontrada nos manuais de História. Já nas demais obras, é comum a inscrição de romance histórico original, romance original ou romance nacional, do que informações complementares sobre peculiaridades da narrativa ou acerca do período histórico reconstruído. Para nós, isto demonstra a estratégia de um autor muito mais preocupado em evidenciar que estes volumes não eram meras imitações ou traduções ${ }^{86}$.

\footnotetext{
${ }^{85}$ Ver Chagas, ACP, [1866] 1870, p.9. Apesar de o subtítulo de Crônicas brasileiras ter sido grafado apenas em $A$ conspiração de Pernambuco, a ideia pode ser estendida À virgem Guaraciaba, já que esta narrativa seria continuação daquela.

${ }^{86}$ Certamente estas inscrições de produção nacional grafadas nos romances eram um indicativo claro de separarem as produções nacionais das inúmeras traduções que se faziam nessa época.
} 
Outra peculiaridade de seu romance histórico é o pouco uso de notas de rodapés ${ }^{87}$ e finais, que são abundantes em A virgem Guaraciaba, mas que vão sendo extintas até chegar ao último romance, O naufrágio de Vicente Sodré. Mesmo porque estes esclarecimentos a todo instante impediriam, na opinião de Chagas, o ritmo narrativo. Nesse aspecto, este autor parece evitá-los ao máximo, utilizando-os apenas quando a veracidade do seu relato estivesse ameaçada.

Por isso, podemos afirmar que Pinheiro Chagas era defensor da atualização da expressão, o que deixa claro em A jóia do vice-rei, quando justifica não utilizar o falar do século XVI, em prol da clareza e da verossimilhança da linguagem e do pensamento das personagens interpretados pelo público de sua época.

Não tentamos nem por sombras ressuscitar a linguagem do século XVI. Essas ressurreições dão ao falar dos personagens um caráter rígido e afetado, mil vezes mais falso do que a tradução da expressão dos seus pensamentos na língua do nosso tempo (CHAGAS, AJVR, [1890] s.d, p. 8).

Essa modernidade da linguagem foi defendida pela primeira vez por Walter Scott na dedicatória que faz ao Dr. Dryasdust, em Ivanhoé. Nela, Scott ressalta que para se efetivar o pacto de ficcionalidade entre leitor e autor, acabava-se criando um anacronismo necessário, provocado pelo

[...]interesse da emoção de qualquer espécie, que o assunto devia ser assumido, por assim dizer, traduzido nas boas maneiras, bem como na língua, da época em que vivemos. [...] obtendo um grau incomparável de aceitação do público, que certamente nunca teria ganho se [estas] maneiras e estilo [não estivessem], em algum grau, familiarizados com os sentimentos e hábitos do leitor [...](SCOTT, [1817] 2005, s.p).

No geral, como adverte Célia Fernández Prieto, este anacronismo linguístico não é sentido, principalmente pelos leitores comuns. E sua presença é justificada para que o leitor contemporâneo pudesse compreender os comentários elaborados pelas personagens históricas. Caso contrário, essas falas tornar-se-iam incompreensíveis se formatadas no pensamento e linguagem da época retratada. Assim, em outras situações, o narrador ao invés

\footnotetext{
${ }^{87}$ Estes recursos para-textuais ajudavam na elucidação de assuntos históricos, expressões linguísticas e dialetos regionais, colocados na boca das personagens ou no corpo narrativo, uma vez que estes arcaísmos incompreensíveis imprimiam, para muitos românticos como Arnaldo Gama, um ar de antiguidade na diegese.
} 
de utilizar a linguagem oral e escrita local, historicamente datada das personagens, ele a traduz, adquirindo o estatuto de tradutor/mediador cultural.

Além do anacronismo linguístico, o romancista histórico pratica o diegético, como adverte Prieto (2003). Ao tentar reconstruir um período histórico distinto do seu e do leitor, o autor irá descrevê-lo, baseando-se em suas impressões do presente, com o propósito claro de discutir questões do seu tempo. Assim,

El anacronismo de la novela histórica consiste en que el passado se revisita y se reescribe com mirada de hoy, de modo que la imagen que se posee en la actualidad sobre aquella época es la que determina su configuración artística. Hablar del pasado, elegirlo, recrearlo, es una forma indirecta de hablar sobre el presente (PRIETO, 2003, p. 191-192).

Esta autora comenta que o anacronismo diegético divide-se em cultural e psicológico. O primeiro facilmente comprovado nas diversas intervenções do narrador com a apresentação de outros textos literários, históricos, alusões a outras obras de autores e referências à arte em geral. Por outro lado, não pode ser suprimido da narrativa a descrição ou citação de elementos materiais ou de costumes da época revisitada: como ambientes, indumentárias, eventos culturais, hábitos alimentares, etc, pois eles constituem a cor local do romance. A descrição de maneira detalhada desses elementos é que irá ajudar a causar um efeito de realismo no leitor atual.

Já o anacronismo psicológico consistiria na maneira como se expressam, agem e decidem os impasses na narrativa, tanto no caso das personagens históricas como nas inventadas. Essa peculiaridade do romance histórico romântico, que é inevitável, parece ter sido compreendida já no século XIX. Garrett, na advertência à edição de 1850 de $O$ arco de Sant' Ana confessou o anacronismo, que padeciam os românticos: “ [...] o romance é deste século: se tirou o seu argumento do décimo quarto, foi escrito sob as impressões do décimo nono; e não o pode nem o quer negar o autor.” (GARRETT, Advertência $2^{a}$. edição, [1850] 1966, p.226). Sampaio Bruno foi outro que, ao definir o romance histórico romântico, alertou para “ [...] as qualidades reais de imaginação inventiva [que] coadunam com a imperfeição do estilo e o anacronismo dos sentimentos postos em ação nas épocas passadas, qualquer que seja, de resto, o conhecimento de pormenores, mais ou menos interessantes” (BRUNO, ([1885] 1984, p.24, grifo nosso). Assim, esta atualização do caráter das personagens possibilita ao leitor se reconhecer na história, já que ele está diante de um tempo culturalmente distanciado do seu. 
Concluindo, no presente capítulo, conhecemos as concepções de romance histórico de Pinheiro Chagas e, principalmente, as suas preferências de períodos do passado nacional. Mostramos que este autor destaca períodos que evidenciam desastrosas políticas dos monarcas portugueses, principalmente em relação às colônias. Para Chagas, uma das causas da decadência portuguesa teria sido essa sucessão de catástrofes feitas por uma monarquia fradesca, egoísta e perdulária, que ajudou a transformar Portugal numa nação de abandonados. 
III

\section{O ROMANCE HISTÓRICO DE PINHEIRO CHAGAS}

Neste capítulo, pretendemos demonstrar que o projeto literário deste autor não era tão oposto ao dos integrantes da Geração de 70, que discutiram a decadência portuguesa. Chagas parece fazer o mesmo em sua ficção histórica quando aponta três proposições importantes que acentuaram e aceleraram o declínio de Portugal: o fanatismo religioso, o absolutismo monárquico e a questão colonial.

Nesse sentido, em A virgem Guaraciaba discutiremos a interferência jesuítica e o francesismo na educação das portuguesas. Já em A máscara vermelha e na sua continuação $O$ juramento da Duquesa, analisaremos as imagens da monarquia e da casa aristocrática portuguesa em ruínas em pleno Portugal restaurado e, finalmente, em A descoberta da Índia. Contada por um marinheiro, a questão colonial. Além disso, ilustraremos o papel que exerce a História na diegese, como também verificaremos como funcionam os elementos cênicos no romance histórico de Pinheiro Chagas.

Apresentados os objetivos da terceira parte deste estudo, passemos então à análise do primeiro romance histórico, em que se percebe uma interferência significativa da efabulação sobre o histórico. Daí, considerarmos que ele se aproxima mais do modelo de um romance com História e não o contrário.

\subsection{A virgem Guaraciaba, numa perspectiva anticlerical}

Enquanto que na Europa, os escritores românticos valorizavam os temas heróicos da Idade Média, no Brasil, o nacionalismo exaltava o indígena, o bom selvagem transformado em herói nas páginas literárias de nossos escritores. O Romantismo brasileiro tinha como foco valorizar as origens da nacionalidade, e para isso elegeu-se o índio, visto como parte integrante e fundador da nação brasileira. Nessa época, dedicado ao tema, José de Alencar publica duas obras, O Guarani e Iracema.

É verdade que em Portugal a literatura brasileira era menos lida do que líamos a portuguesa e, em certos gêneros, menos ainda que a francesa. Sobre isso, Raymond Sayers (1983) ilustra em seu livro uma referência feita por Pinheiro Chagas quanto a dizer que era mais fácil estudar um livro chinês traduzido em francês do que um livro brasileiro. ${ }^{88}$ De

\footnotetext{
${ }^{88}$ Cf. Sayers, 1983, p.203-04. Estas ideias estão discutidas numa seção, Bibliografia Brasileira, da revista $O$ Brasil.
} 
acordo com o crítico americano, Chagas, ao finalizar o seu artigo, retoma-o com ironia em afirmar que do Brasil as únicas importações que se faziam eram de gêneros alimentícios: café, açúcar e as bananas. Apesar dessas dificuldades e de outras de ordem alfandegária, que aumentavam o custo do livro brasileiro em relação ao português, alguns títulos chegavam às mãos da crítica portuguesa. Prova disso é a publicação portuguesa de A Virgem Guaraciaba (1866), de Pinheiro Chagas, que confessadamente diz ter se utilizado, além de outros compêndios de História, das notas do autor de Iracema para compor a cor local de seu primeiro romance.

Contudo, a crítica da época - dentre essas, a própria réplica ${ }^{89}$ de Alencar a Pinheiro Chagas - desqualifica esteticamente a obra portuguesa. Nas suas considerações, Alencar avalia a publicação como meramente industrial, e, portanto, fadada ao insucesso até mesmo no seu tempo de produção.

Havia, é claro, muita fundamentação nas advertências alencarianas, principalmente no que se refere à descrição do cenário colonial e da cultura indígena, pois o narrador aparece hesitante na composição da cor local. Pelo fato de não ser tanto a reconstituição do período colonial que se ocupava Chagas, de muito lhe valeram ${ }^{90}$, na concepção de Maria Aparecida Ribeiro (2009) ${ }^{91}$, os romances de O guarani e Iracema. Segundo esta autora, de maneira quase literal, Chagas recorre a cenas, linguagem e hábitos dos ameríndios apresentados por Alencar nos dois romances, principalmente da obra Iracema, para compor os seus episódios da primeira parte de A virgem Guaraciaba.

Se em algumas cenas e personagens de A virgem Guaraciaba há uma sombra de $O$ guarani [pela aproximação física e psicológica que é feita entre Ceci e Beatriz e o fascínio de Caetéguara por Beatriz, aparentemente, assemelhando-se àquele que tem Peri por Ceci], a presença de Iracema é nítida, principalmente na primeira parte do livro. O romance português começa com a caminhada dos padres Aspicuelta Navarro e Salvador Rodrigues. Como Martim, que aparece em Iracema desamparado dos seus nas terras dos Tabajaras e encontra a filha de Araquém, os padres deparam-

\footnotetext{
${ }^{89}$ A resposta de Alencar, referente à polêmica dos neologismos, está compilada na segunda edição de Iracema. Nesta contenda, Pinheiro Chagas defende que a língua brasileira vai se diferenciando da portuguesa, não o suficiente para chegar a ser um dialeto, mas o bastante para que pareça incorreta aos falantes do português. Ver ainda o estudo sobre esta contenda realizado por Gladstone Chaves de Melo (1972).

${ }^{90}$ Como fundamentação histórica, Chagas recorre à investigação minuciosa feita por Alencar para compor Iracema (1865) Além, é claro, de textos propriamente de História, como História do Brasil, de Ferdinand Denis, e de F. A. Varnhagem.

${ }^{91}$ Ver Ribeiro, 2009, p.75. Esta autora comenta que, embora haja um desconhecimento por parte do público português, pode-se encontrar três edições da obra em Portugal, “ a primeira é de Lisboa, Afra \& C., Livraria Enciclopédica, 1866; as duas outras não têm data, mas são também da responsabilidade de editoras de Lisboa: a Empresa Lusitana Mundial, que possuía um depositário no Rio de Janeiro - a Livraria Editora Jacinto Silva. Esta última faz parte da Collecção Selecta — Obras Primas da Literatura Mundial — e é anterior a 1913”.
} 
se, repentinamente, com uma festa antropofágica. [...] Uma índia aparece: como Iracema, ' a morena virgem', cujo 'pé grácil e nu, mal roçando, alisava a verde pelúcia que vestia a terra com as primeiras àguas [...] também esta 'índia morena e graciosa', ' tocando apenas com o pé breve e nu na relva da campina, corria em direção de uma choupana’ (RIBEIRO, 2009, p.78).

Segundo Maria Aparecida Ribeiro (2009), ainda que A virgem Guaraciaba seja um livro quase desconhecido entre os portugueses, esta obra pode ser considerada como prova de fascínio do seu autor por Alencar, mesmo depois de algumas polêmicas oriundas das censuras que Chagas fez ao romance. "Pinheiro Chagas tomá-lo-ia como mestre, ao mesmo tempo em que tentava torná-lo discípulo” (RIBEIRO, 2009, p.77). A maneira como Chagas se apóia nas investigações de Alencar para construir a cor local de sua história sobre o Brasil colonial e algumas cenas do próprio romance alencariano, evidencia-nos mais um caso típico de inspiração, como adverte Antonio Cândido (2004). Para este crítico, ocorre uma “[...] fertilização entre os textos, [...] [ou seja] um texto se constitui mais a partir de outros do que a partir do registro direto dos movimentos da alma ou dos aspectos do mundo. [...] o que se pode chamar de ressonância, concebida como o eco de um texto em outro”. Daí, consideramos que nos escritos de Pinheiro Chagas há uma confluência entre as várias vozes que ali se encontram, não só de Vitor Hugo, que esteve sempre no horizonte estético do autor de A virgem Guaraciaba, mas de Walter Scott, José de Alencar, Camilo Castelo Branco e Silva Gaio, entre outros.

Outra crítica, a de Luísa Marinho Antunes (2009), conclui que a proposta de Pinheiro Chagas não é tanto se servir da história como pretexto para a sua trama amorosa, mas mostrar de modo apologético as contribuições dos portugueses na colonização do Brasil.

A Virgem Guaraciaba constitui-se, efetivamente, como retrato do mundo que o português estava a criar no momento histórico a que se reporta o romance e da sua responsabilidade histórica. O ponto de vista é, por isso, o do pai que relembra as suas façanhas e olha para o filho de ontem e de hoje com orgulho, vendo nele seu produto cultural e histórico, continuação de seu espírito (ANTUNES, 2009, p.444).

Nelson Vieira (1991), ao discutir as imagens do Brasil no livro em questão, acaba compartilhando com as mesmas considerações que faz Luísa Antunes, e ainda acrescenta que “ [...] indiferente às suas barbaridades [a do clero], o autor sempre justifica as ações dos jesuítas porque eles são o meio pelo qual o Brasil se tornará católico” (VIEIRA, 1991, p. 98). Não desprezamos que, em algumas passagens do livro, há um tom laudatório com que o autor 
exalta a ação portuguesa na História colonial. Mas, a nosso ver, pelo contrário, independente do espaço, a intenção principal de Chagas era criticar a influência exagerada do clero sobre a sociedade portuguesa quinhentista, assunto que apresenta logo na introdução de $A$ virgem Guaraciaba. Assim, é compreensível que o índio ocupe o segundo plano da narrativa, já que o objetivo do romancista é

prestar justiça aos merecimentos desses homens [os jesuítas] que tanto ódio inspiraram, desejando ao mesmo tempo fazer com que o leitor não perdesse de vista a índole da sociedade, e a frieza com que removia os mais ligeiros obstáculos, que tentassem opor-se-lhe (CHAGAS, AVG, [1866] s.d, p.13).

Já aqui há um engodo do narrador, que diz prestar justiça os merecimentos dos jesuítas. Com isso, o leitor desavisado fica esperando que ele enalteça a ordem de Loyola, o que não ocorre. $\mathrm{Na}$ verdade, toda a trama encaminha-se para uma desmitificação das ações do clero, que “removia os mais ligeiros obstáculos, que tentassem opor-se-lhe”.

Posto isto, é inegável que a força motriz da urdidura desse drama não estivesse na figura indígena como em Iracema e O Guarani. Na obra de Chagas, ela perpassa pelas ações dos jesuítas. Tanto assim, que Aspicuelta Navarro convence ardilosamente Beatriz, agenciando-a em prol da fé católica, na conversão de Caetéguara. E quando percebe que Jaime pode interferir nesse projeto, trama para que outro jesuíta confidencie ao mancebo sobre as intenções amorosas do chefe da tribo por Beatriz, que levam o português a matar o indígena. Diante disso, resta-lhe apenas professar, não como forma de expiação, mas como meio de ocultar o seu crime, já que, tempos depois, o frade sem hesitar mata Villancey, o novo pretendente da mulher que ele amava. A frequente inclusão de crimes relacionados ao clero é, na visão de Maria de Fátima Marinho, própria de uma “ [...] política liberal [e se] torna responsável pelo tom frequentemente crítico e irônico que se imprime à atuação destes clérigos, nem sempre altos modelos de virtudes” (MARINHO, 2005, p.223).

Embora isso, Jaime é o típico herói romântico tanto pela sua composição passional, melancólica e solitária, quanto pelo destino trágico que tem, ao enlouquecer. Sobre os possíveis desenlaces de uma intriga romântica, Carlos da Mata Induráin considera que só há duas possibilidades: “ [...] Quando os amantes conseguem vencer os obstáculos que os separam, seu amor e o enfrentamento resultam no matrimônio feliz. Caso contrário, o fim trágico é inevitável, como o desespero, a loucura e a morte dos protagonistas” (INDURÁIN, 1998, p.132-133). Além do desfecho que tem suas personagens, que confirma alguns elementos de ordem romântica, em A virgem Guaraciaba, podemos encontrar outras situações 
típicas do romance histórico romântico: o presságio de Jaime de uma possível traição de Beatriz no momento em que ele viaja para defender Pernambuco; o duelo entre Jaime e os outros admiradores de Beatriz e a fuga do Forte dos Franceses, quando esta é salva de forma heroica por Jaime, que agora era padre. Nessa passagem, embora as personagens históricas, como Mr. De Villancey, interfiram na ação, o protagonismo está a cargo de personagens inventadas, os dois amantes. Visto por este ângulo, esta intriga amorosa cheia de peripécias poderia se desenvolver em qualquer outro período histórico, que não o colonial, sem que isso interferisse na trama. Mas isso não quer dizer que as figuras históricas nessa ação romanesca não sejam importantes. Apesar de estas estarem no segundo plano da narrativa, no romance histórico, elas favorecem a autenticidade da história narrada, e no caso dos jesuítas, são suas maquinações que impedem os protagonistas de ficarem juntos.

Aliás, a ordem de Loyola é evidenciada como tirânica, apesar de o narrador desta ficção evitar estabelecer um juízo crítico direto. Seu julgamento é posto de maneira ilustrativa quando conta episódios inusitados e, porque não, cômicos como o leilão e a venda do Pe. Manuel de Paiva junto com os jumentos numa feira livre ${ }^{92}$. Este acontecimento confirma que, naquele tempo, a Companhia de Jesus era um Estado paralelo ao colonial, pois eles pareciam não temer nem mesmo o intendente Tomé de Sousa, que observava incrédulo e temeroso à distância a humilhação do sacerdote.

[...] o padre Manuel de Paiva ia ser adjudicado aos moradores de Vila Velha, quando o padre Nóbrega apareceu e explicou ao povo, num eloquente sermão, a prova de obediência que infligira ao seu subordinado. Todos se retiraram, benzendo-se e elevando as nuvens a virtude dos jesuítas. Tomé de Sousa sentiu-se aliviado de um grande peso, porque principiava a achar a cena escandalosa, e os moradores de Vila Velha resignaram-se a ir com os cento e vinte cruzados comprar jumentos, que tinham vindo de Portugal, em vez de comprarem um capelão (CHAGAS, AVG, [1866] s.d, p.102).

Diante dos desmandos da igreja estabelece-se um processo de coisificação, desde Pe. Manuel de Paiva que fora vendido como um animal até a virgem Guaraciaba ${ }^{93}$ que é

\footnotetext{
${ }^{92}$ Ver Chagas, $A V G$, [1866] s.d, p. 306. Conforme a nota, o autor explica que não fantasiou este fato, que jura ser verídico. Adverte ainda que apenas o transcreveu fielmente das crônicas de Simão de Vasconcelos sobre um acontecimento envolvendo Pe. Manuel de Paiva, que teria sido leiloado pelos seus confrades como penitência por sua insubordinação. " Sempre que narramos aos leitores algumas destas extravagâncias jesuíticas, que revoltam o sentimento do bom, do justo, e do moral, receamos que nos acusem do romancear, e citamos logo as fontes. Seguimos este sistema, transcreveremos aqui o período que na crônica de Simão de Vasconcelos a este caso se refere”.

${ }_{93}^{93}$ Ver Alencar, [1865] 1948, p.68. A virgem Guaraciaba, que na língua tupi quer dizer “uma virgem de cabelo de sol”. Essa característica dada por Chagas a sua personagem foi colhida em uma nota em que Alencar afirma ser
} 
agenciada na conversão do chefe indígena. Mas este sentimento de subserviência que se instaura na personalidade de Beatriz só é possível devido à educação excessivamente beata que recebera da mãe. Depois que a menina ficara órfã, a ausência materna é preenchida pela presença de tutores e confessores religiosos, mesmo contrariando a vontade do pai. Numa cena, quando os jesuítas começam a pregar sobre a conduta cristã que eles deveriam assumir na conversão dos nativos, o pai de Beatriz ensaia uma contestação, que é sutilmente condenada pelo olhar da filha.

[...]. E afastou-se vagarosamente [Pero Cristovão]. A conversação que principiara tão alegre, resfriou-se de súbito. Pero Cristóvão ficara de mau humor, Beatriz, educada por sua mãe em ideias exageradamente devotas, olhava para seu pai com um modo de tímida reprovação. [...](CHAGAS, $A V G$, [1866], s.d, p. 71).

- Beatriz, disse Pero Cristóvão entre severo e sentido, grandes contas tem que dar a Deus tua mãe por ter haver educado nesses princípios que te levam a censurar as ações de teu pai [por ter dado um lance pelo leilão do jesuíta].

- Perdoa-me, senhor! Tornou Beatriz abaixando os olhos, mas com voz firme, os meus deveres para com Deus estão antes dos meus deveres de filha. Disse Jesus: 'Não me ama quem ama seu pai e sua mãe mais do que a mim’ (IDEM, p.101).

À medida que se intensifica a intervenção do confessor espiritual na vida de Beatriz, a autoridade paternal vai perdendo forças. A ideia do padre inserido no seio familiar enfraquecia as relações familiares ${ }^{94}$, pois além de ele conhecer todos os vícios, segredos e desejos por meio da confissão, também se determinava as resoluções a serem tomadas.

Dessa maneira, servindo aos propósitos maquiavélicos da ordem, Beatriz é uma presa fácil, não só pelo seu fanatismo religioso, mas principalmente por sua vaidade, que a torna vulnerável à ilusão de ter sido a escolhida para a missão sublime de evangelizar os índios: “[...] sois uma eleita do Senhor, sois quase da tribo sagrada, sois uma das virgens prudentes que esperam com a lâmpada acesa a volta do divino esposo [...]” (IDEM, p.274, grifo nosso). Na caracterização de suas heroínas, Pinheiro Chagas parece ressaltar o vício da jactância que as cegam, tornando-as facilmente manipuladas pela astúcia das outras personagens. Quando

essa a maneira pelo qual os indígenas nomeavam os europeus que tinham cabelos louros.” Em tupi guaraciaba. Assim, chamavam os indígenas aos europeus que tinham os cabelos louros.

${ }^{94}$ Ver Ortigão, [1870] 1970, p.216. No artigo nomeado A decadência da raça pelos vícios da educação, seu autor seguindo uma exposição sob a ótica de Darwin tenta explicar a declínio português. " A história da nossa decadência oferece a mais perfeita confirmação das leis de Darwin. As nobres faculdades que fizeram de nós um povo exemplar até o século XV atrofiam-se até darem a degeneração pelo exercício e pelo hábito, pela hereditariedade e pela seleção artificial. O militarismo seria insuficiente para explicar uma transformação tão profunda como aquela por que passamos”. Para ele, a confissão tornada obrigatória com o Concílio de Trento era prejudicial, pois incentivava a traição, infiltrando a desconfiança tanto nas relações externas como as de dentro do lar. 
isso ocorre, a mulher coloca em jogo não só a vida, mas a sua consciência, liberdade e destino, como ocorrem com Madalena, de Os guerrilheiros da morte, Inês Mendes, de A máscara vermelha e Terezinha, de $O$ terremoto de Lisboa. Para cada uma dessas, reservamos mais à frente uma discussão sobre os seus caracteres.

Como ocorrerem com essas mulheres, a vaidade de Beatriz conspira para a sua queda. No grande tabuleiro da ordem, ela é mais uma no sacrifício da honrosa empresa da fé. Contudo, a personagem só se percebe como um títere nas mãos dos soldados de Loyola e sente remorsos, depois que a fatalidade recai sobre si com a morte de Caetéguara e com a ordenação forçada de Jaime.

[...] Desaparecia a cristã com os seus escrúpulos, e reaparecia a mulher. E Beatriz perguntava a si mesma dolorosamente se os desgostos, as privações, as fadigas não haveriam morto para sempre aquela formosura tão decantada na corte, e se a mulher de trinta anos não seria apenas o espectro da criança de vinte. (CHAGAS, $A V G$, [1866] s.d, p.217-218)

Beatriz, percebendo que na sua relação com os jesuítas se criara um ciclo vicioso de chantagens e subserviência, prefere a morte a se manter refém das vontades deles. Embora o suicídio seja um indicativo romântico, a moça assume uma postura viril e subversiva ao se jogar do penhasco na frente de Pe. Anchieta, depois das sutis ameaças que recebera.

Beatriz não parou, não demorou a doida carreira em que vinha, não ajoelhou sequer, murmurou apenas:

- Meu Deus, perdoe-me.

E precipitou-se no rio.

$[\ldots]$

O jesuíta [Jaime], que ao longe contemplava imóvel o rio, correu soltando um grito.

$[\ldots]$

O jesuíta soltou um grito horrível, e louco de desesperação quis-se precipitar em seguimento daquele amado corpo. Retiveram-no os dois braços vigorosos, e o padre José de Anchieta, pálido e ofegante da sua longa carreira, disse lhe com voz firme:

- Se morreis, quem expiará o crime? (IDEM, p.282-283).

Indiferente à morte de Beatriz, Pe. Anchieta lembra a Jaime mais um dos preceitos da ordem jesuítica, além da obediência, a resignação. Assim, ele é convencido a renunciar o suicídio e aceitar uma vida de penitências, em nome do pecado que a amada cometera ao se 
matar. Jaime sucumbe aos argumentos do grande padre e, a partir de então, parece confirmar a subjugação do homem às leis do jesuitismo.

Os infortúnios a que são submetidos estas personagens nos fazem pensar que eles ajudam a assegurar a expressão latina Ad majorem dei gloriam, isto quer dizer, Para a glória do Senhor. Sempre que os frades alcançavam seus objetivos, eles selavam a conquista com esta premissa. Por meio dela, podemos depreender que todos, perto dos desmandos da igreja, perdem a sua subjetividade, restando-lhes apenas a morte. Por isso morrem Caetéguara, Beatriz e, até certo ponto, Jaime que enlouquece. resta-nos apenas depreender que todos, perto dos desmandos da igreja perdem a sua subjetividade, 109109109109109109109109109109109109109109109109109109109109Mas das personagens elencadas, Beatriz é a única que, ao final da narrativa, começa a se distanciar do perfil romântico de heroína, indicando já uma outra tendência de Pinheiro Chagas em retratar mulheres subversivas.

Não só esta personagem inventada sofre um tipo de desromantização, mas também aquelas que se referem aos principais vultos históricos do período retratado, como Pe. Anchieta, figuram mais próximos da verdade histórica, mais realistas. Com respeito ao caráter de pureza e caridade que é associado a ele, Dulce Mindlin (1997, p.24) esclarece que essa ideia é incompatível “principalmente nas cartas do ‘apóstolo do Brasil’ [em que] é frequente a alusão aos selvagens nos termos mais pejorativos” (MINDLIN, 1997, p.24).

Essa imagem de um padre arrogante e insensível ao padecimento das minorias pode ser comparada à maneira com que reage aos sofrimentos de Beatriz. Mesmo sabendo do espírito atormentado da moça, o sacerdote não se compadece e aparece defendendo, acima de sua conduta cristã, os interesses suspeitosos da missão, manipulando o destino do casal português: “Que religião era aquela, que princípios inspiravam a Companhia de Jesus aos membros, que nem o mais santo deles podia derramar a ânfora das doces consolações nas almas ulceradas, que se vinham abrigar no seu seio. (IDEM, p.278).

Como se pode ver até aqui, o narrador não isenta nem mesmo o santo padre do processo de alienação da ordem. Ficando a cargo da Igreja a educação moral do indivíduo, este não compreendia racionalmente as situações, pois acreditava que o seu destino era a vontade da Providência. O panorama de uma sociedade imoral, hipócrita e acéfala recuperado do século XVI em A virgem Guaraciaba não era diferente daquele que Chagas observava em seu tempo. Se aproximarmos o caráter de Beatriz ao protótipo das moças lisboetas descrito por Eça de Queirós em Uma Campanha alegre, veremos que ele se encaixa sem muito esforço ao discutido até aqui. 
Mas a vaidade infiltra-se na alma, gota a gota, e cria no fundo aquele lago imóvel, negro e resplandecente, onde, segundo os Místicos, habita e se move o Pecado.

Ao mesmo tempo vai-se-lhe ensinando o catecismo e a doutrina. É a educação moral. [...] Depois, seguidamente, decora todas as orações da cartilha. E termina por papaguear a Doutrina correntemente, de cor, e salteada, [...] - mas sem a menor compreensão, sem ligar uma ideia sua às palavras mortas, sentindo através delas um certo terror - porque se trata de Deus e segundo lhe ensinam é Deus quem manda as trovoadas, as doenças, a morte. [...]

Diante pois de qualquer circunstância da vida ela, religiosa, cristã e devota - como não pode guiar pela religião que desconhece - guia-se pelo instinto ou pelo capricho. A religião de que tanta fala, e que tanto usa, aos domingos na Igreja, e à sexta-feira na cozinha, não lhe serve muito [...]. Porque no fim, o que a governa - é o instinto.

Contra as tentações da vida, ela não terá no seu espírito conselho, força, resistência ou interesse superior. Uma ilusão, um momento de abandono podem-na perder: e toda a copiosa, aparatosa doutrina que lhe ensinaram e que não percebeu - não a pode salvar (QUEIRÓS, [1872] 1946, p.116-119).

Em síntese, o pensamento eciano resume que a portuguesa do século XIX “ [...] na presença do mundo tentador - esta[va] [...] desarmada” (IDEM, p. 129) e a doutrina religiosa que lhe ensinaram de nada lhe serviria se estivesse em perigo.

Buscando refúgio nas histórias do passado ou não, Pinheiro Chagas vai se ocupar em retratar esse feminino vulnerável que, também descrito por Eça de Queirós, vivia entre rosários e as futilidades da vida cortesã. Dele agora trataremos. 


\subsubsection{As portuguesas de Pinheiro Chagas, devotas ou afrancesadas}

Numa das suas jornadas no paraíso, Dante refere-se à sua amada como “[...] aquela que me guia com sua explicação. Minha alma aclara. E a verdade, qual astro, me alumia” (ALIGHIERI, canto XXVIII, 1955, p.232). Guiado pela amada, Dante atravessa os diversos planos celestiais. Uma vez que ele se encontra espiritualmente pronto, Beatriz não é mais necessária para que ele enxergue o amor emanado de Deus.

Como mediadora, quase maternal, do conhecimento (verdade/luz), a amada de Dante o conduz, apontando-lhe o necessário, encurtando-lhe os caminhos. Tal assertiva confirma, portanto, o raciocínio elaborado por Nicolas Berdiaeff, que vê na mulher “[...] um importante papel [...]. Ela está mais ligada do que o homem à alma do mundo, às primeiras forças elementares, e é através da mulher que o homem comunga com essas forças [...]” (BERDIAEFF, 1927, p. 162-163 apud CHEVALIER, 2003, p. 421). Eça de Queirós, em Uma campanha alegre, também relaciona a mulher ao futuro da nação. No seu ponto de vista,

\footnotetext{
A valia de uma geração depende da educação que recebeu das mães. [...] A educação dos primeiros anos, a mais dominante, a que mais penetra, é feita pela mãe: os grandes princípios, religião, amor trabalho, amor do dever, obediência, honestidade, bondade, é ela que lhos deposita na alma [...]. Dizme a mãe que tiveste - dir-te-ei o destino que terá. A ação de uma geração é a expansão pública do temperamento das mães (QUEIRÓS, [1872] 1946, p.105).
}

Nesse trecho, fica evidente o papel decisivo que o autor de O crime do Padre Amaro dispensa à mulher na educação dos filhos. Mas essa concepção positiva sobre o feminino nem sempre se deu assim. Antes de setecentos, Sílvia Alexim Nunes (2000) considerou, no seu interessante capítulo $O$ século XVIII e a construção da imagem materna, que a figura construída da mulher [...] é aquela herdada do Cristianismo primitivo, que sobreviveu durante toda a Idade Média e o Renascimento. Para os filósofos de então, a mulher era vista como um ser mais carnal, dotada de sentimentos maléficos e de um desregramento sexual ameaçador (NUNES, 2000, p.22). Na visão medieval, a mulher era concebida como dissimulada, que incitava a luxúria e a maldade entre os homens. Biblicamente, sua inferioridade derivaria de seu nascimento de uma costela de Adão, como ainda o seu lado diabólico advinha de sua descendência de Eva, que sucumbiu à influência da serpente. Desse modo, o sexo feminino 
visto como ameaça maligna à sociedade perdura durante todo o período medieval e no Renascimento ele vai ser associado à bruxaria.

A partir do século XVIII, ocorre uma inversão de valores, a mulher deixa de ser associada à Eva e passa a ser identificada com Maria. Assim, atributos como fragilidade e sensibilidade passam a ser considerados fundamentais para delegar à mulher a responsabilidade da educação dos filhos.

A mulher não é mais identificada a uma criatura diabólica. Ela se transforma numa pessoa doce e sensata, de quem se espera comedimento e indulgência. Eva cede lugar a Maria. A curiosa, a ambiciosa, a audaciosa, metamorfoseia-se numa criatura modesta e ponderada cujas ambições não ultrapassam o limite do lar. A imperfeição dá lugar à perfeição na medida em que tem início uma nova concepção sobre a diferença entre homens e mulheres (IDEM, p.28-29).

Desde então, a intelectualidade passou a discutir novos rumos para o preparo dessas educadoras. Para o fortalecimento dessa nova vertente, como elucida Silvia Nunes (2000), a reforma luterana foi decisiva. Lutero defendia que, independente do gênero, todos deveriam ler para serem capazes de interpretar as escrituras e, assim, serem donos de sua própria salvação. Mesmo igualando os direitos da mulher ao do homem no acesso às letras, esta doutrina restringia o saber, como forma de manutenção da dominação patriarcal sobre a família e a sociedade.

Já a Igreja Católica só começa a ver a mulher como um instrumento ideal as suas causas depois de Lutero, segundo Sílvia Nunes (2000). Sob o ponto de vista católico, baseado na visão luterana sobre o saber feminino, “ em cada uma estaria adormecida uma potencial educadora que poderia transmitir sua doutrina. Essa tomada de consciência confere um impulso decisivo à generalização da instrução feminina, que deveria compreender pelo menos a leitura do catecismo” (IDEM, p.26).

Em A virgem Guaraciaba, Beatriz de Souza é este tipo de mulher que serve inocentemente aos projetos de expansão da fé. A mesma ideia de salvar almas ocorre a Amaro para explicar as idas frequentes de Amélia à casa do tio Esguelhas, lugar escolhido pelo padre para os encontros furtivos do casal. Amaro sabia que a proposta de catequizar Totó não teria a menor contestação e seria recebida com jubilo cristão por todos: o clero, as beatas e a mãe.

Apesar de serem tramas e estilos distintos, nos dois romances seus autores mostram uma educação falsamente beata que ambas as personagens recebem e que, de certo modo, anunciam as suas ruínas, porque elas não conseguem se desvencilhar das tentações do mundo. 
Mas, além disso, a vulnerabilidade de ambas ao delito é facilitada pela vaidade tanto da heroína romântica como da realista. Beatriz, mesmo sabendo que a conversão destruiria Caetéguara e toda a sua tribo, não recua, pois era uma missão divina, como já explicitamos. Amélia, embalada pelo mesmo sentimento de orgulho, sente por Amaro - mais do que atração pelo homem - a vontade irresistível de profanar o sagrado. Mas passado a excitação da conquista, nas duas situações, as personagens vão sendo consumidas pela culpa e pelo remorso, que aos poucos dão lugar a momentos de lucidez. Beatriz, impedida de amar Jaime, consegue ver agora com nitidez a extensão do estrago feito em suas vidas pelas maquinações dos jesuítas. Já Amélia se percebe apenas como um troféu nas mãos de Amaro, simplesmente a amante do padre.

E essa curiosidade [saber se Jaime ainda a amava] tinha um não sei que de febril. Desaparecia a cristã com os seus escrúpulos, e reaparecia a mulher. E Beatriz perguntava a si mesma dolorosamente se os desgostos, as privações, as fadigas não haveriam morto para sempre aquela formosura tão decantada na corte, e se a mulher de trinta anos não seria apenas o espectro da criança de vinte (CHAGAS, $A V G$, [1866] s.d, p.218).

Mas Amélia, agora, já não tinha aquela necessidade amorosa de contentar em tudo o Sr. Pároco. Acordara quase inteiramente daquele adormecimento estúpido da alma e do corpo, em que a lançara o primeiro abraço de Amaro. Vinha-lhe aparecendo distintamente a consciência pungente da sua culpa. Naqueles negrumes de um espírito beato e escravo fazia-se um amanhecimento de razão (QUEIRÓS, [1874] 2009, p.268).

Mas se estas duas personagens além de escravas de suas devoções místicas romantizavam o caráter das pessoas e a vida, Clara de Portugal, uma das heroínas de A mantilha de Beatriz, de Pinheiro Chagas, mesmo sendo criada num ambiente altamente beato, surpreende pela sua independência e sagacidade.

[Clara] ficara órfã, apenas com seis anos de idade; [...]. Entregara-a aos cuidados mercenários das criadas e à vigilância de uma tia velha, quase paralítica, extremamente devota, que, enquanto pudera sair, passara a maior parte do tempo nas igrejas e que depois, quando a paralisia a prendera em casa, passava apenas, na sua cadeira de rodas, do seu quarto de cama para o seu oratório, não recebia senão visitas quase oficiais das fidalgas suas parentas, as dos frades da sua devoção e as dessas beatas, que o Arcipreste de Hita chamava no seu tempo de Trota-conventos. [...] Nestas condições Clara poderia facilmente perder-se. Não tinha ninguém que lhe indicasse o que era o mal e como ele devia evitar-se. Não tinha outra defesa contra a hipocrisia e a sedução das Celestinas, senão a sua inocência, que era talvez antes um perigo. Mas a orfandade precoce e o desamparo em que se via tinham dado ao seu jovial espírito uma têmpera robusta, haviam-lhe dado ao 
caráter uma seriedade prematura e um pouco melancólica. [...] Fora esse ente angélico [a proteção espiritual da mãe] que lhe dera desde os quinze anos um vago aspecto senhoril e como que maternal. [...] (CHAGAS, AMB, 1878, p. 59-60, grifo do autor)

Clara, sabendo dos limites impostos à mulher numa sociedade patriarcal, inteligentemente nunca buscava o confronto com seus adversários, pois numa dessas lutas diretas poderia perder o que lhe era mais caro, a liberdade. Impacientava-se a tia em torná-la freira; já o irmão - desejoso de fazer do casamento um negócio rentável - há muito lhe dera um ultimato: “[...] casar ou meter-se freira, [...] [pois] é necessário que te apresses a dar uma decisão” (IDEM, p. 68). Mas o caráter perspicaz e diplomático de Clara consegue burlar essas imposições, fazendo que a sua vontade, no final das contas, imperasse: casar-se ${ }^{95}$ com o homem que amava.

Como transgressora das convenções sociais de seu tempo, Clara permite que seu par tenha acesso, sem nenhum constrangimento, aos seus aposentos, quando a autoridade masculina não estava em casa. Num desses episódios, na tentativa de tirar D. Estevão de casa, pois o amante (D. Luiz) estava a caminho, Clara ardilosamente convence o irmão a ir buscar, tarde da noite, suas joias na casa da vizinha Beatriz, mulher que ele amava. Neste ponto, observa-se como ela se utiliza da fraqueza do irmão a seu favor para atingir os seus propósitos. Diferente do caráter passivo de sua amiga Beatriz de Souza, que deixa tudo a cargo de sua criada Inês, Clara resolve todas as situações de conflito que a vida lhe impõe. E a última coisa que permitiria seria ser mandada e governada por alguém. Além disso, em nome do desejo, Clara não mensura a intensidade e as consequências de seus atos, colocando até mesmo a sua honra em risco constante.

Em A mantilha de Beatriz, Pinheiro Chagas apresenta a vida portuguesa como uma verdadeira comédia ${ }^{96}$. Assim, assuntos ligados à honra e ao casamento são, de certa forma, ridicularizados por algumas personagens dessa obra.

\footnotetext{
${ }^{95}$ Talvez uma extensão dos elementos do Romantismo, para estas personagens, o casamento não se configura como uma clausura quando se realiza com o ser amado. Por tal razão, a referida cerimônia de união não ameaça a sua liberdade. Com diplomacia, quando estão casadas com aqueles que amam ou não, elas conduziriam suas vidas e governariam o mundo masculino.

${ }^{96}$ Ver Chagas, FT, 1878. Em Fora da terra, o narrador ao viajar pelo interior do país vai discutindo sobre vários assuntos, que surgem por suas observações pelos lugares que passa. No prefácio deste livro, seu amigo e escritor Júlio César Machado compara a vida portuguesa àquela dos dramas de Victorien Sardou: "A família portuguesa ficou Benoiton: essa é a história; gente ratona e avara. [...] Uns pequenos que andam no colégio e já vão às corridas, e já são piteireiros: meninas, que não leem senão jornais de modas, que se vestem como as moças de má nota, que pintam os olhos para fingir que os têm maiores, arranjam penteados levados de mil diabos, e usam saia de fantasia arregaçada intencionalmente. Mães que nunca estão em casa, e que são da idade das filhas; uns
} 
D. Álvaro de Mascarenhas, pai de Beatriz, é um caso clássico, que beira a caricatura, quando defende os bons costumes, ${ }^{97}$ sendo constantemente vítima dos enganos de Inês - que burla sua vigilância - e da zombaria de Luís Alcoforado, que ridiculariza a maneira como protege a honra da filha, se preciso fosse pelo uso da espada. ${ }^{98}$ Aliás, será também o noivo de Clara quem debochará da ideia romanesca do pai de Beatriz ao considerar que o casamento resolve tudo, principalmente em situações em que a dignidade feminina é posta em perigo.

Mas, nas vozes de personagem mais beatas, o casamento passa a ser uma recomendação para acalmar o instinto feminino. Dessa maneira pensava a devota D. Lucrecia Borges ${ }^{99}$ que, quando não cuidava de apressar o matrimônio de D. Antão ${ }^{100}$ com a afilhada de seu marido ${ }^{101}$, estava no “[...] seu quarto onde esbrugava rosários sem fim” (CHAGAS, AMI, 1890, p. 201).

Apesar de seu temperamento decisivo, como o de Clara, Catarina, de A marquesa das Índias, ${ }^{102}$ sempre evitava contrariar ou aborrecer os tios. Assim, ela não faz resistência ao matrimônio arranjado, pois vê que pode se aproveitar das prerrogativas do compromisso para continuar tendo uma vida livre. Ou melhor, poderia agora escolher os amantes.

- Que remédio! Respondeu Catarina. Já que o sr. Jorge Cabral [tutor de Catarina na ausência de seu pai, que estava em Diu] quer por força casar as suas hóspedas [ela e Dolores], eu, que sou a mais antiga, não hei de ficar para trás. Voltemos, pois, aos nossos antigos projetos [os casamentos com D. Antão e, da parte da amiga, o seu casamento com Lisuarte Barreto]. Lá diz o provérbio, D. Antão: guardado está o bocado para quem o há de comer.

\footnotetext{
asnos chapados que passam por grandes luminárias pelo fato simplesmente de não apreciarem senão o lado comercial das coisas; donzelonas presumidas, burlescas, ares de menina e moça apesar do que nós sabemos, dizendo mal de tudo e de todos, e escrevendo cartas anônimas, coquetes que dão a entender que o marido deve ser cavalo de carga ajoujado com o carro conjugal [...]” (CHAGAS, FT, 1878, p. VIII).

${ }^{97}$ Ver Chagas, MBA, [1879] s.d, p. 89. D. Álvaro repreende a filha e adverte o vizinho (D. Álvaro) sobre a quebra de decoro em sua casa. Depois, acrescenta: "Sabes, porém, que prezo, acima de tudo, o decoro das damas, esse decoro que se vai perdendo em Portugal com a vinda de estrangeiros”.

${ }^{98}$ Idem, p. 53. "Ele guarda a filha com um rigor de nobre de comédia castelhana”.

${ }^{99}$ Esta personagem de A marquesa das Índias é também apelidada de Madame Benoiton do século XVI. Uma evidência clara de anacronismo cultural do autor.

${ }^{100}$ Alusão clara a Ermitão, antigo pretendente de Inês Pereira, que fora preterido pelo galante Brás da Mata. Depois de sofrer muito com as intransigências do jovem marido, Inês, que enviuvara, casa-se com aquele que iria prover-lhe uma vida cheia de mimos. Sentimento similar que sentia Catarina por Antão, que só se casou com ele por imposição dos padrinhos.

${ }^{101} \mathrm{O}$ envolvimento desta personagem referencial, Jorge Cabral, que na realidade foi o governador das Índias, coloca-o no mesmo patamar das inventadas, que estão submetidas à lógica da ficção.

${ }^{102}$ Esta trama envolvente, ao estilo de capa e espada, passa-se no período do domínio português em Goa (Índia), cujo rei, o sultão Badur, fizera a espanhola Dolores como uma de suas noivas. O destino da marquesa das Índias, codinome dado à estrangeira, entrecruza-se com o da impetuosa e matreira portuguesa Catarina de Sá. Numa manhã, Catarina conhece e se impressiona com Lisuarte Barreto, que - sem ela saber - é amante de Dolores e responde pelo nome de João Santiago. Por outro lado, Santiago é amigo do noivo de Catarina, D. Antão de Noronha. Como em A mantilha de Beatriz, os personagens passam por vários percalços cômicos, típicos das histórias de Calderón, que só vão ser desenlaçados ao final, com o casamento dos dois casais, mesmo que a contragosto de Santiago e Catarina, com seus respectivos pares.
} 
E deitou um olhar malicioso para João de Santiago (CHAGAS, AMI, 1890, p. 242).

Neste sentido, independente de terem casado com o homem que amavam ou não, o importante era a preservação da liberdade de escolha. Na galeria das portuguesas sem determinação e governadas de Pinheiro Chagas, não há espaço para Clara nem para Catarina, porque elas são senhoras de si e de seus destinos, subvertendo o poder patriarcal. Pelo fato de determinar o próprio caminho a seguir ou de se utilizar da situação, Clara e Catarina se diferenciam dos outros tipos, que - como fantoches nas mãos outros - acabam se autodestruindo, consumidos pela certeza da impossibilidade do vir-a-ser.

Nesse grupo, por exemplo, encaixa-se a impetuosa Terezinha, de O terremoto de Lisboa, como um desses tipos que acabam sendo destruídas por sua vaidade e ambição. Esta personagem representa o protótipo da heroína romântica, que oscila entre a mulher angelical e a demoníaca.

Era linda, mas de uma beleza em que havia um não sei que de magnético e de perigoso. Os seus grandes olhos negros às vezes despediam chamas, outras vezes amorteciam-se numa languidez em que parecia refletir-se toda a sensualidade oriental. [...] Em Tereza havia duas mulheres distintas, uma cândida, meiga, boa, quando as paixões encontradas, que rugiam na sua alma como opostos vendavais, lhe não turvavam a serenidade, outra que despertava com o despertar dos veementes afetos, e que devia ter nos acessos de loucura amorosa os êxtases insensatos das mulheres do oriente, nos ímpetos de cólera o rugido feroz das leoas, que devia ou enroscar-se como a cobra nos braços do homem a quem amasse, ou silvar como a serpente furiosa que dardeja a língua farpada contra o inimigo que a irrita (CHAGAS, OTL, 1874, p. 37-38).

Luiz Correia, oficial do regimento real, torna-se o seu protetor depois que a salva de um incêndio no orfanato de São Domingos. Apesar de ele ser um homem bom e íntegro, Tereza não o ama. Com a essência da perversidade no íntimo, bastou, então, conhecer D. Carlos para que ela cedesse aos seus galanteios e fugisse da casa da madrinha, certa de estar conquistando liberdade, aventura e luxo em sua companhia.

Carlos, no entanto, tinha um caráter vil. Sabendo que D. João V era seu pai, ele se associa ao Marquês de Pombal para transformar Tereza na concubina de D. José. O propósito era que a amante se transformasse na primeira conselheira, minando a crescente influência dos jesuítas nas decisões do reino. ${ }^{103}$ No agenciamento de Tereza, Carlos tenta convencer o

\footnotetext{
${ }^{103}$ Ver Chagas, OTL, [1872] 1874, p. 124. "E eu [Marquês de Pombal], se quiser resistir à influência do confessor, hei de procurar a influência da amante”.
} 
primeiro ministro de que ela era a pessoa certa, pois não teria nenhum escrúpulo, caso fosse bem recompensada.

\begin{abstract}
- Afirmo a v. exa. que estudei a fundo o caráter daquela menina. Contanto que possa brilhar, saborear as doçuras do luxo e da riqueza, aceita a situação mais irregular deste mundo. Tem poucos escrúpulos a pequena. Por isso também tenciono jogar com ela jogo liso e franco. Antes de a arrojar ao estrado das Pompadour, hei de negociar o contrato.

Havia na linguagem de D. Carlos um cinismo tão impudente, que Sebastião de Carvalho, apesar de costumado a não olhar para os meios, contanto que alcançasse os fins, não pôde reprimir um movimento de repugnância (CHAGAS, OTL, 1874, p.123).
\end{abstract}

Mas quando se descobre irmão da mulher, que mantinha como amante, enfurece-se e jura mais do que nunca exterminar com todos da realeza. Dos dois, extremamente indiferentes ao sofrimento alheio, somente Tereza, instantes antes de morrer, reconhece o seu leviano modo de tratar as pessoas que lhe amaram.

Parece-nos que os desvios de conduta tanto de Carlos quanto de Tereza são justificados na narrativa pela ausência de uma mãe que pudesse ensinar-lhes os primeiros princípios de honra, amor, trabalho e altruísmo. Terezinha, numa carta à madrinha, ao justificar a maneira ingrata e imprudente que tomava ao fugir com um homem que mal conhecia, esta personagem atribui a terceiros as desgraças que lhe aconteceram e poderiam vir a acontecer. “[...] Eu sou uma desgraçada, minha querida madrinha. Hei de sê-lo sempre. Mas que quer? Não fui eu que fiz este meu gênio volúvel, não fui eu que colaborei na fatalidade do meu destino" (CHAGAS, OTL, 1974, p. 92). Achando-se mais esperta que todos, Tereza é vítima de sua própria ambição e vaidade, que não deixavam que ela percebesse realmente o caráter do seu pretendente.

Como teria sido também a vaidade de ser uma mulher fatal que deixa Inês Mendes, de A máscara vermelha, impossibilitada de ver a verdadeira índole do marido. Num diálogo entre D. João da Costa e Pedro Bonete, aquele explica que

[...] a vaidade de uma mulher é tão docemente acariciada pelas paixões que a sua formosura inspira, o coração feminino é tão fácil para a indulgência com o amor arrebatado de um homem, que não há crime por mais odioso que seja, que não possa contar com o perdão daquela por cuja causa se cometeu (CHAGAS, OJD, [1873] s.d, p. 99).

Inês Mendes é mais outro exemplo desse tipo de mulher despreparada para as armadilhas da vida. Depois que D. Pedro Bonete comete o estupro contra ela, este se diz vitimado e 
enfeitiçado por sua beleza: “- Não quereis desculpar à violência do amor, que de súbito me inspirastes, o excesso que fui levado a cometer?” [Fala de D. Pedro Bonete] (CHAGAS, AMV, [1873], s.d, p.42). A passividade e credulidade dessa personagem confirmam o seu perfil de mulher-anjo romântica. Assim, a sua trajetória será sofrer enganos e fatalidades.

Era realmente uma criatura formosíssima. As longas tranças negras ondeadas flutuavam-lhe soltas sobre os ombros, o rosto, que tinha esta palidez morena das peninsulares, refletia nas animadas feições o entusiasmo com que essa gentil menina se oferecia ao martírio para salvar a vida de um velho [Santa Coloma, vice-rei da Cataluña], que o povo inteiro perseguia com seu ódio. Os olhos negros chispavam chamas e era tão ardente o seu olhar, que se diria que fora o fogo das pupilas que lhe crestara ao de leve as faces pálidas. Os lábios, um pouco grossos, tinham esse vermelho vivíssimo, que denuncia umas vagas tendências provocadoras de sensualidade. $O$ seio arquejava-lhe ofegante $e$ solevantava precipitadamente o corpo do vestido. O colo, de uma extraordinária pureza de formas, dourado também por beijos do sol, arqueava-se numa curva graciosa, deixando que os olhos ávidos de quem a contemplasse seguissem por um momento contornos suaves, que a imaginação completava. [...] Era mais um dos muitos exemplares do gracioso tipo peninsular, mas exalando um inebriante perfume de voluptuosidade, que se tornava talvez mais entontecedor pelo contraste que se formava com a atitude suplicante da aflita menina [...] (CHAGAS, AMV, [1890] s.d, p. 30-31 destaque nosso).

Toda a cena é preparada para a violência sexual a seguir. Há mesmo uma insinuação de que existiria um desejo inconsciente da personagem na consumação do ato devido à sua voluptuosidade. Outro detalhe importante nesse episódio, apesar de uma valorização da plasticidade, é a hesitação do narrador na descrição das passagens mais aviltantes. Há, portanto, uma romantização dos termos, tais como, gentil menina, lábios pouco grossos, curva graciosa e sensualidade brutal.

- Sabeis o preço do meu silêncio, murmurou D. Pedro, e o seu hálito abrasado bafejava o rosto da gentil mulher [Inês]; num momento de hesitação e o conde está perdido e perdido sem que ao mesmo tempo vos salveis, porque o palácio foi tomado de assalto e conheceis os usos da guerra em tais circunstâncias. Não vos pouparão os outros, se eu não vos salvar: escolhei entre a minha proteção que traz consigo a salvação do conde e o serdes vós e o conde entregues à fúria brutal dos populares.

- Hão de respeitar-me, bradou ela com os olhos chamejantes de cólera e a voz balbuciante de terror, que estes dois sentimentos se confundiam no seu espírito, hão de respeitar-me, que nem todos serão uns monstros como vós sois. [...]

- Isto é uma infâmia, murmurou ela, quase desmaiada, é uma infâmia sem nome! Fazei de mim o que quiserdes! Mas que ele se salve ao menos!

- Ah! És minha, enfim! Bradou com um grito o catalão.

E tomando-a nos braços, com uma presa sofregamente desejada, levou-a soluçante, quase inerte, com a fronte pendida sobre o seu ombro e uma 
voluptuosidade infinita o invadia ao sentir no rosto o contato perfumado das longas tranças soltas, enquanto ao longe vibrava o rebate, o estrondear dos canhões, os tiros de fuzilaria, todos os rumores sinistros de uma cidade em cujas ruas tumultuam às soltas a revolta brutal (CHAGAS, AMV, [1873] s.d, p. 32-33).

É visível a condenação do narrador à atitude heroica da gentil menina em salvar um velho que já estava condenado à morte por corrupção, que - se não pela espada do mercenário catalão - seria pelas mãos da multidão. Inês parece ser essa mulher confinada num mundo sentimental, que confunde o parecer com o ser, confiando na bondade alheia. Nas cenas finais, ao ser descoberto como o algoz, num ímpeto de fúria, Pedro mata Inês. No entanto, ela complacente o perdoa e até mesmo suplica para que ele fuja.

Inês Mendes e Terezinha são exemplos clássicos das mulheres seduzidas de Pinheiro Chagas, que mesmo depois que são submetidas à torpeza de seus violadores vão morar com eles. Tanto D. Pedro quanto Carlos, de O terremoto de Lisboa, são ambiciosos e vingativos e fazem de suas amantes uma espécie de trampolim para suas negociatas.

Também Madalena, de Os guerrilheiros da morte, padecerá do mesmo vício de vaidade. Contudo, diferente de Inês, aquela assume um papel mais próximo da personalidade de Terezinha, o de mulher demoníaca. Sempre que o narrador se refere ao seu caráter, ele procura ressaltar a sua voluptuosidade.

Filha dos condes de Vila Velha, ela desde a infância já mostrava uma tendência à vivacidade e à sedução do masculino. Entre eles estava Jaime Cordeiro de Altavila, filho da criada dos pais de Madalena, que crescera amando-a sem, contudo, obter êxito, pois ela só lhe tinha amor fraternal. Forçada a noviciar por conveniência familiar, mas sem nenhuma vocação para a vida monástica, ela foge no momento em que tropas francesas invadem o convento. Na mesma ocasião, conhece um oficial francês e se entrega a ele sem expressar qualquer remorso por isso. Sobre a cena, diferente da violência sexual que sofre Inês Mendes, em Os guerrilheiros da morte, o narrador recusa-se a descrever fielmente a sedução de Madalena.

Não seguiremos passo a passo esses amores; quantas vezes se tem descrito a queda de uma mulher, quantas vezes se tem visto, ao sopro ardente da paixão, tisnarem-se as asas de um anjo, e a mulher, em cuja cândida fronte se refletia a inocência, e se projetava a sombra das asas do serafim zeloso que a velava, entrar enfim louca, fascinada, no mundo das pecadoras, onde, depois de passageiros, no mundo das pecadoras, onde, depois de passageiros enlevos, se acorda tendo-se à cabeceira o remorso e a vergonha!(IDEM, p. 249, grifo nosso). 
Nem resignada e muito menos arrependida, assim vivia Madalena depois que fora viver com o francês. Tempos depois, Jaime a reencontra mudada, diferente da menina que povoara os seus sonhos de rapaz:

Jaime olhou para ela com um riso sarcástico. Parecia impossível que esses dois entes já [se] tivessem amado; os seus olhares cruzavam-se chamejantes de ódio, implacáveis, furiosos. Jaime não a amara; amara a companheira da sua infância, tímida, casta, graciosa, não aquela amazona desenvolta, enérgica, atrevida, que reivindicava como uma glória o seu pecaminoso amor (IDEM, p. 277).

Pelo fragmento, há nitidamente dois tipos bem definidos de mulher. O herói do drama elege o primeiro como o ideal, sendo que o segundo modelo, por sua virilidade e rebeldia, passa a ser indiferente ao mancebo.

Quando novamente o convento é saqueado, ela, ao fugir, morre afogada na enchente da Ponte das Barcas. Parece-nos que, o narrador condena a personagem não por sua maneira transgressora, mas por sua volubilidade, que culmina no seu antipatriotismo. Esta mulher “[...] morrera vítima do apaixonado amor que votara ao estrangeiro que a seduzira” (IDEM, p. 287). Dessa maneira, os fins trágicos dessas personagens se devem ao seu espírito fútil, inconstante e vaidoso.

Até aqui em nossa exposição, algumas questões relativas ao mundo feminino são pontuadas na narrativa de Chagas, mesmo que de forma velada, como o casamento e a educação dos filhos. Sobre o discutido, trazemos à luz um estudo interessante pela abordagem, que o faz de modo epistolar, e pela delicadeza com que trata as matérias relativas à formação das mulheres. Em Mulheres e crianças: notas sobre educação (1880), ${ }^{104}$ Maria Amália Vaz de Carvalho defendia que toda mulher deve receber uma educação intelectualizada, para decidir por si mesma que caminho seguir, abrindo, com isso, outras possibilidades para seu futuro, que não só o casamento.

Assim, [a mulher] absorvida pelo estudo bem dirigido, pelas elevadas distrações intelectuais, assim educada, fortalecida, elucidada, verá como ela chega à idade própria de escolher o seu destino, possuindo um são critério, uma penetração delicada, uma firmeza de princípios que a ponha ao abrigo

\footnotetext{
${ }^{104}$ Ver Carvalho, s.d, livro virtual. Nesta obra, a autora se dirige a amigos sem nome por meio de cartas, na representatividade do coletivo, ou seja, de forma que o interlocutor possa ser facilmente substituído pelo leitor do livro. Os temas da obra, que compreendem os mais variados assuntos do universo feminino, vão desde literaturas recomendáveis às meninas em formação até o comportamento adequado em lugares sociais, como bailes, teatros, etc.
} 
de qualquer tentação menos digna (CARVALHO, livro virtual, 1880, s.p, grifo nosso).

Portanto, não só o futuro das mulheres a serviço da civilização, enquanto mães, estaria em jogo, mas também os destinos daqueles que dependessem de sua proteção e lucidez. Neste mesmo texto, Vaz de Carvalho, num estilo confessional, considera que as intervenções femininas na formação dos filhos nem sempre são acertadas (porque por vezes são titubeantes e imaturas) e que o mundo espera muito destas mulheres constantemente hesitantes.

Pois tu não ouviste que ele [o filho] espera, e que a primeira palavra definida e clara que há de vibrar na sua alma, sou eu que hei de dizê-la, é a minha mão trêmula, fraca e inexperiente que há de tornar-se firme para a gravar indelevelmente? (IDEM, carta a uma amiga, s.p).

Assim, mesmo diante das incertezas próprias do ato de educar, a autora tece algumas qualidades inerentes à mulher, que deve se desdobrar no papel de mãe zelosa e extremada, de economista do lar, mas acima de tudo ser, ao lado do marido,

companheira do seu espírito, a sócia das suas aspirações, a inteligência que compreenda e partilhe as suas legítimas ambições, e as suas quimeras fantasias, o ânimo viril [que] saiba ampará-lo nas horas de desalento, a mão firme e branda, que saiba guiá-lo nos momentos escuros de luta e de tentação: o seio terno que lhe acolha a cabeça cansada na hora sinistra das derrotas, [...] numa palavra, a mulher digna de ser mão e de educar uma geração de fortes (IDEM, livro virtual, s.p.).

Sobre isso, o texto de Vaz de Carvalho elucida mais um importante dado quanto à leitura feita pelo público feminino. Algumas delas legitimadas pela autora, outras nem tanto, sendo que estas últimas são consideradas nocivas ao espírito, tendo a obra de Lamartine dada como exemplo.

Disse-me ontem que sua filha tinha esgotado a pequena biblioteca. A leitura pode fazer-lhe muito mal ou muito bem; não pode de modo algum ser-lhe indiferente. A minha amiga, seguindo as tradições que já encontrou assentes, pergunta-me se pode deixar ler a sua filha Paulo e Virginia [...] ou Jocelyn [...]. Fala-me no Gênio do cristianismo, de Chateaubriand, e nas tragédias sacras de Racine. Antes de mais nada, responda-me francamente: quer fazer de sua filha uma mulher solidamente instruída ou então uma mulher ignorante? Quer que ela saiba resistir às tentações que forçosamente há de encontrar na vida ou quer que ela se conserve na mais completa e absoluta inexperiência até a idade em que há de entregá-la ao homem que tem de ser seu marido? [...] [Depois de citar alguns autores, como Walter 
Scott, parte para o ataque à literatura que só promove a deseducação do espírito por meio da poesia melodramática] Ninguém tem medo de Lamartine. As mães dão-no a ler às suas filhas, os noivos de presente às suas noivas. Para todos eles, é o mais alto dos poetas, um cisne que nunca maculou as suas penas brancas no lodaçal das paixões insalubres (IDEM, livro virtual, s.p.).

No final, a escritora conclui que mesmo as produções literárias de cunho idealistas podem fazer parte da biblioteca particular da mulher, desde que sejam na sua fase de maturidade, em que seu discernimento tem bases fortes e lúcidas.

Não há dúvidas de que a leitura feminina consistia em uma das preocupações da intelectualidade portuguesa. Em $O$ segredo da Viscondessa ${ }^{105}$, de Pinheiro Chagas, ele ridiculariza essa educação literária falsa e estéril que cultivava a personagem Sofia Leite, que se trata mais de um tipo que de uma pessoa. Para impressionar o noivo, ela recitava longos trechos dos livros que lia e falava duas ou três línguas estrangeiras.

[Sofia Leite] Era o que se chamava uma menina prendada; tocava piano, desenhava sofrivelmente, lia duas páginas de um romance francês, podia também admirar no original as belezas de Sir Walter Scott, e sabia o italiano suficiente para não estropiar a letra das romanzas que cantava com voz de sala menos má. Sua mãe orgulhava-se muito com os talentos poliglotas de sua filha, e julgava que não havia no mundo inteiro quem se lhe pudesse comparar, nem menina que merecesse fixar, mais do que sua filha, as atenções de todos os homens; era um orgulho desculpável num coração de mãe, mas devemos confessar que a Sra. D. Mariana Leite apregoava, mais do que seria necessário, os dotes de sua filha, e falava constantemente da nuvem de pretendentes que aspiravam à honra da sua mão, e do cortejo de admiradores que os seus talentos lhe atraíam (CHAGAS, OSV, 1871, p. 131-132).

O limitado mundo do lar é um espaço dedicado à frivolidade e ociosidade feminina. É quase nula a presença de mulheres trabalhando nos seus lares, quando não estão se dedicando a atividades prazenteiras (leitura, trabalhos de bordados, cantos, jogatinas e o piano), os espaços domésticos são sempre preteridos pelo feminino de Chagas, que prefere ganhar o mundo. Nem mesmo as criadas, como as duas personagens chamadas Inês de A mantilha de Beatriz e A marquesa das Índias, se dedicam aos afazeres relativos à casa. Pelo contrário, como elas

\footnotetext{
${ }^{105}$ Romance de atualidade, sua narrativa é estruturada em forma de correspondências em que se confidenciam, no primeiro bloco, Amélia de Castro com a amiga Sofia Leite sobre os dias no campo e sua aparente aversão ao noivo da amiga. E, no último bloco, a Viscondessa de B. (Albertina) narra a Julieta o encantamento que sentira pelo jovem pároco e de como intencionava coqueteá-lo. Nas duas confidências, encontram-se digressões interessantes sobre arte e literatura, principalmente no que se refere ao Arcadismo e ao Romantismo e à feitura de romances.
} 
têm o passe livre para sair, estabelecem os contatos com o mundo exterior para suas damas. Em outras ocasiões, assumem, por vezes, a posição de deus ex machina ${ }^{106}$ quando a honra da patroa estivesse em risco. Nesse sentido, Neide Elias considera que

As criadas operam como elementos de articulação entre o espaço doméstico e público, elo de dois mundos distintos, uma realidade de sentimentos e de traços culturais populares ignorados por aqueles que vivem o universo do espaço doméstico burguês (ELIAS, 2006, p. 330).

No modelo feminino dependente dos conselhos e ações das criadas se encaixa Beatriz, de A mantilha de Beatriz. Mesmo transgredindo as convenções sociais, ela é dependente da astúcia de sua aia, Inês Pereira, para preservar a sua reputação. Tanto assim que Inês é quem dá a ideia para a ama legitimar o uso da mantilha dada por Francisco de Mendonça. ${ }^{107}$ Por esta e outras situações, são os criados, Inês/Gonçalo e Inês/Estevão, que exercem sempre funções de mediadores nas questões amorosas dos seus amos e, por terem vivacidade, estão sempre à frente dos outros. Sabem da importância de suas intervenções e, conhecendo o desespero dos enamorados, tiram proveitos da situação.

- Saiu. Bem sei, leva-me ao aposento de Beatriz [pediu Gonçalo, que vinha a mando de Francisco]. E, dizendo isto, metia uma moeda de ouro nas mãos da ladina criada. - Generoso como um rei! Murmurou Inês, que sem fazer mais objeções, o foi conduzindo para a sala onde sua ama estava. Já me não admira que seja esperto o Gonçalo; não há nada que abra tanto o engenho como o retrato de sua majestade... o ouro (CHAGAS, AMB, [1879] s.d, p. 44).

Em outros episódios, conseguem, assim, perceber as confusões e tirar desforra dos envolvidos, que ainda não perceberam o ridículo da cena.

Apenas eles saíram [D. Álvaro e D. Estevão], Beatriz convulsa ergueu-se. Ia para chamar Inês, mas esta antecipou-se ao chamamento, entrando, ao mesmo tempo que Beatriz corria a abrir a porta do quarto ao seu namorado. - Inês, disse ela, salva-me depressa. Esconde-o, e, logo que meu pai volte, dá-lhe escápula para a rua. [...]

\footnotetext{
${ }^{106}$ Ver Moisés, 2004, p. 119. Tendo sua origem no teatro grego, consiste em uma personagem ou artefato inserido na narrativa com a intenção de resolver uma situação aparentemente insolúvel. Sua intervenção inesperada, mas oportuna, objetiva nada mais do que dar sentido à narração.

${ }^{107} \mathrm{O}$ plano traçado por Inês consistia em pedir a Clara que usasse a prenda em visita à casa de Beatriz. Dessa maneira, no momento em que estivessem na presença de D. Álvaro, ela deveria dissimular o desejo de presentear a amiga com o adorno.
} 
Francisco de Mendonça fez um gesto de desespero e ia a sair, acompanhando Inês, quando esta, que da porta vigiava o que se passava nas salas próximas, lhe fez sinal que parasse e pôs ao mesmo tempo o ouvido à escuta. [...]

E empurrando Francisco de Mendonça, fê-lo entrar de novo no quarto donde acabava de sair.

- Isto é que se chama saber tomar uma precaução a tempo! O Sr. D. Álvaro, que não quer que a menina receba visitas de homens na sua sala, fecha-os à chave na alcova (CHAGAS, AMB, [1879] s.d, p. 87-88, grifo nosso).

Estas inflexões humorísticas refletem tão somente a jocosidade e sagacidade do espírito da criada. Em A mantilha de Beatriz, o desenrolar da ação perpassa pelas mãos de Inês. Com isso, parece-nos que Pinheiro Chagas se agrada tanto do engenho da personagem que, pelo protagonismo que ela exerce na diegese, desbanca Beatriz e Francisco de suas condições de personagens centrais.

Contudo, não só as criadas espertas, como Inês, são evidenciadas. Pinheiro Chagas também vai retratar as mexeriqueiras, que tramam contra os patrões. Um desses tipos é Maria do Rosário de A flor seca. Esta empregada, que debulhava orações enquanto falava, vivia à espreita, a mando de D. Antonia, para vasculhar os segredos e testemunhar os supostos deslizes amorosos de Margarida.

A constante vigilância de D. Antonia, uma espécie de Juliana de O primo Basílio, recalcada e ressentida, transforma a vida de Margarida num verdadeiro inferno. Além disso, todas as vezes que o marido se omitia diante das provocações maliciosas e acusações injuriosas da tia em relação a ela, Margarida se sentia mais só ${ }^{108}$ e desiludida com o casamento.

À mesa do jantar, onde todos [os] três nos reunimos, choviam sobre mim as alusões às senhoras que preferem o piano ao governo da sua casa, às senhoras casadas que dançam nos bailes, quando seus maridos não dançam, à corrupção do século, aos maus costumes que importamos de França, à leitura perniciosa dos romances, tudo isso precedido do inevitável (IDEM, p. 27).

\footnotetext{
${ }^{108}$ Margarida não recebe sequer a visita de mãe, depois que se casa. Aliás, parece ser uma dificuldade de Chagas a faculdade criativa de inventar mães, porque praticamente a figura materna se ausenta das páginas do seu corpus ficcional. Neste livro em específico, ela só aparece no início dos relatos da filha, que narra uma espécie de memorial de casamento e, depois, desaparece.
} 
Pelo seu temperamento romântico, Margarida refugia-se nas artes e nas leituras dos romances franceses, mas nem por isso negligencia o seu lado pragmático, incentivado desde pequena por seus pais.

[...] Imaginem essa criança, educada, rígida, severa, prosaicamente por um pai, que franzia o sobrolho sempre que me via disposta a soltar as rédeas à imaginação, por uma mãe, que me fazia sentar junto de si, e me dizia: 'Filha, é preciso resignares-te a abandonar essas ideias românticas, se quiseres viver tranquila e feliz. O mundo não é como tu o vês através do prisma da tua infantil imaginação. Os sonhos da fantasia, filha, são como as andorinhas: só vivem bem entre os eflúvios de uma eterna primavera. [...] Filha, prepara-te para afrontares serenamente as tristezas e amarguras da realidade! (CHAGAS, AFS, [1866] 1904, p. 13-14).

Oscilando entre dois mundos incompatíveis, ela desenvolve uma

[...] dupla existência: uma toda sujeita às leis sociais, e não tentando por forma alguma rebelar-se contra elas, outra completamente fora do mundo da realidade; existências diversas, com as fronteiras escrupulosamente traçadas, e que nunca se invadiam mutuamente (CHAGAS, AFS, [1866] 1904, p. 17).

Convivendo num ambiente de pessoas hipócritas, moralistas e mexeriqueiras, Margarida se vê desamparada e infeliz diante da passividade do marido em relação à tirania da tia. Ao redor desta personagem, o autor reúne uma galeria de tipos caricaturais que exemplificam essa decadência da sociedade lisboeta.

Pobre criança [refere-se à Margarida], não está ainda habituada a estranha sociedade, no meio da qual o acaso a colocou. Tudo aqui é frívolo, minha querida, e tudo toma uma aparência grave e pedante, como um alfarrábio teológico; tudo é imoral, e tudo toma ares austeros. Máscara, máscara e máscara; nada mais. Se estou bem informada, um dos artigos do regulamento dos bailes públicos proíbe as máscaras religiosas, mas não há lei alguma, que me conste, que as proíba na sociedade, onde existem com abundância, há-de-se acostumar também, minha filha, há de fazer o que eu faço, envergar um dominó da confraria, e rir-se dos outros, por baixo da máscara como eles se riem de nós (IDEM, p.104).

Este olhar desencantado sobre a família vista como instituição burguesa, que revela D. Carolina, mulher adúltera e infeliz no casamento, reflete o enfado e a dissimulação feminina que burla as convenções sociais, as quais ela estava sujeita. Será por meio da fala dessa personagem que tanto Margarida como o leitor conhecem “[...] o caráter desses dois 
personagens [a condessa, tia de Carolina, e o seu marido], com quem me vejo obrigada a estar sempre em cena nesta comédia da vida” (IDEM, p. 106). Carolina retrata o marido como um pústula, que representa papéis de um homem de princípios e devoto. Num mesmo tom depreciativo, a tia condessa é descrita como uma fidalga de falso moralismo, pois no passado tivera casos com padres e agora era intolerante com as moças, que sob sua tutela, pudessem ter relacionamentos íntimos sem se casarem. Sua desculpa era de não pactuar com as imoralidades cristãs.

Encerrada no templo, curvando o joelho ao altar, e transformando em alcova a sacristia, zombou das tolas que pecavam em plena rua, e sobre as quais os seus lábios, ainda frementes de lascívia, arrojavam com impudência o sacrilégio anátema. Não julgues contudo que era a condessa uma exceção no meio da aristocracia feliz, que pode receber ... nas suas salas a brilhante juventude monástica (CHAGAS, AFS, [1866] 1904, p. 107).

Estas pessoas, que faziam parte do círculo de amizade de D. Antonia, representavam a decadência da sociedade portuguesa, revelando um microcosmo de hipocrisia, ociosidade, falcatruas e bajulações.

Além da crítica social que existe neste romance citadino de Pinheiro Chagas - que não é tão conhecido como Madame Bovary (1857), de Gustave Flaubert e O primo Basílio (1878), de Eça de Queirós - o leitor não deixa de perceber uma certa aproximação entre as heroínas dos três romances. Contudo, o fato de a narrativa d' A flor seca ser escrita em $1^{\text {a }}$. pessoa, ao estilo de confidências, parece imprimir uma perspectiva mais intimista do universo feminino, ao abordar assuntos ligados ao matrimônio, adultérios, intrigas, etc.

A protagonista feminina, Margarida da Silveira, casa-se sem amor com Cláudio de Castro, homem de caráter fraco, muito influenciado pela tia D. Antonia. Esta aliada a um grupo de fidalgas-beatas incita e sugere o adultério da mulher do sobrinho com o melhor amigo deste, Alberto. Muito apessoado, este jovem no passado começara a amar Margarida, sem o conhecimento desta. No dia em que Alberto declara o seu amor, ele presenteia-a com uma flor. Mesmo amando Alberto, Margarida se sacrifica pelo casamento. Cláudio, ao perceber a nobreza da esposa, propõe a ela um novo começo, pedindo somente que quando ela o amasse lhe desse a flor seca presenteada por Alberto.

Embora Margarida não seja uma mulher fútil como Emma e Luísa, ela se sente sozinha no casamento e a monotonia de sua vida faz com que ela se lance ao mundo aventureiro dos romances franceses. 
Sentei-me com desalento numa cadeira, e deixei pender a cabeça nas mãos. Senti quanto é horrorosa a solidão quando se tem vinte anos e um coração ardente. [...] Era esse quarto o símbolo da minha existência, tal como o destino me fizera, cárcere sombrio e lúgubre onde eu tinha que encerrar todas as aspirações da minha juventude, todo o fogo vital que me incendia o sangue. [...]

Margarida, exclamei eu, és tu a criança descuidosa, que há pouco dançavas nos bailes com tão mimoso colorido nas faces? Es tu a flor das salas? Como estás desbotada, rosa das valsas! Definhas à sombra; mas que sol te poderia reanimar?

' o amor!' suspirou uma voz íntima, e o quarto iluminou-se com vagos e ignotos clarões, e a tempestade como que se acalmou por encanto, e a sua voz expirante balbuciou aos meus ouvidos: ' o amor!' (IDEM, p.84).

Porque eu chegara a convencer-me que tudo aquilo era verdade e não ficção, que era eu a heroína da ópera, ele o meu apaixonado, e quando, todo embevecido nessas recordações, Alberto, como que esquecendo-se do presente, concentrou toda a sua alma, toda a sua paixão naquele grito imenso de amor e de jubilo (IDEM, p.185).

Além disso, o desejo incontido de agitar os seus dias como antes e as diversas situações provocadas pelo triunfeminato (D. Antonia, a Condessa e D. Carolina) em deixá-la a sós com Alberto, o melhor amigo de seu marido, conspiravam para que o adultério ocorresse. Contudo, ela não cede aos encantos de Alberto, mesmo este se declarando apaixonado. Ela renuncia ao amor e se resigna surpreendentemente em continuar casada com Cláudio. Se os devaneios românticos de Emma Bovary e Luisa acabam de um modo particularmente trágico, a trajetória de Margarida toma rumos distintos ao das duas personagens anteriores devido à intensidade de seu caráter e a maneira como racionaliza o amor.

Entre a minha aflição, contudo, avultava uma ideia fixa. 'Não, dizia eu comigo mesma, isto não pode durar. Vejo dois caminhos abertos diante de mim, o do amor e da perdição, e o da salvação e do martírio. Ou entregarme à paixão fatal, que me domina, fazer a vontade a esta gente [referência ao grupo de D. Antonia] e procurar no amor de Alberto consolações, que me abafem os remorsos, ou fazer cessar esta luta perigosa, dizendo a Alberto que parta, [...]. Se conquisto a paz interior, as tempestades nem por isso deixarão de me bramir no coração. Mas que importa? O cumprimento de um dever nunca deixa de ser acompanhado por íntima satisfação, e será esse o mágico talismã que abrandará o sofrimento, a que a minha vida vai ser condenada. É preciso, é indispensável que Alberto se ausente. Ausentai-vos com ele, sonhos tentadores, perigosos devaneios, frêmitos da juventude, [...].(IDEM, p.187).

A protagonista deste drama, pelo seu ceticismo, sabia que seria quase impossível que ela pudesse ter uma nova vida com Alberto. Na formulação desse argumento, ela se serve dos 
motivos que impediram os heróis dos romances de ficarem juntos. Aquelas mesmas histórias que um dia embalaram os seus sonhos e a fizeram cobiçar aquelas aventuras para si.

\begin{abstract}
Sorria-me tentadora a ideia fatal de esquecer nos braços de Alberto a vida e as suas obrigações, o mundo e as suas amarguras, de fugir com ele para algum eremitério arredado do bulício social, ufanando-me do estigma, aceitando o escândalo para conquistar o amor, como se aceita o martírio para se conquistar a palma. Bem sei que seria de pouca dura essa felicidade criminosa, que o remorso seria meu algoz, e o enfado, que algumas vezes me entreluzisse nos olhos do meu amante, pugentíssimo castigo; mas o que era tudo isso em comparação da longa vida de estelionato que eu ia passar nesse cárcere doméstico? Lembrei-me dos amores de D. Branca e de AbénAfan. Horas breves de felicidade compradas por uma vida inteira de horrendo desgosto; e o que destruíra esses amores tão violentos? Um gesto de fastio do moiro wali, saudoso das suas pelejas e do seu poder. Teria eu maior condão que D. Branca, Alberto mais desprendimento do mundo do que Abén-Afan? Não lhe leria nunca nos olhos o desgosto de se ter prendido em laços não autor autorizados pela sociedade, e de se ver privado dos gozos mundanos? (IDEM, p.192, grifo nosso).
\end{abstract}

Margarida compreendia que o mesmo egoísmo, que impulsionara os amantes ao adultério, favorecia tempos depois o enfado e o desgaste da relação. No paralelismo que estabelece entre a sua realidade e a ficção que lia, ela entende que ninguém era tão altruísta que quisesse abandonar a sua própria individualidade em nome de um amor por outra pessoa. Apesar desta postura pragmática que assume diante do amor, a sua abnegação e resignação, por outro lado, faz desta protagonista a personificação do sacrifício, o que torna a sua dimensão humana idealizada, pouco provável.

Mas este protótipo da mulher desprendida, que Margarida representa, novamente irá protagonizar as páginas de outro romance urbano, publicado no mesmo ano de 1866, Tristezas à beira-mar. Neste livro, ainda que se encontrem cenas e expressões melodramáticas, como em A flor seca, Pinheiro Chagas sutilmente chama a atenção de suas leitoras para o modo europeizado que iam ganhando as portuguesas, diferentemente do biótipo trigueiro, ${ }^{109}$ próprio do povo peninsular. Eça de Queirós, nesse sentido, concorda com Pinheiro Chagas, que a descaracterização da portuguesa, além de destruir a sua beleza natural, desvirtuava-lhe o espírito.

\footnotetext{
${ }^{109}$ Ver Chagas [1879] s.d, p. 37. Denominação dada por Pinheiro Chagas às portugueses num trecho em que as diferencia das estrangeiras: "[...] encontram-se muitas damas como a Sra. Beatriz de Mascarenhas. As mais bonitas são todas trigueiraças, que parece que as tisnou o fogo do inferno. Mas louras, de olhos azuis, brancas rosadas, parecendo mesmo umas estrangeiras, isso é que por cá se não topa”.
} 
Um caixeiro desenha a lápis, em Paris, um certo chapéu, um certo corpete, umas certas mangas - e todas, magras e gordas, as louras e as trigueiras, as altas e as pequeninas, se introduzem, se alojam, se enfiam naquele molde, sem se preocuparem se o seu corpo, a sua cor, o seu perfil, a sua altura, o seu peito, condizem, harmonizam, vão bom com o molde decretado e chegado pelo correio. Abandonando-se servilmente ao figurino, abdicam a sua originalidade, o seu gosto. [...] Desabitua o espírito da invenção, da espontaneidade, da liberdade. [...] Seguir um figurino é aprender a elegância de cor, para a ir recitar na rua; é ter o gosto que se recebeu de encomenda; é alugar o chiq, ao mês; é mandar vir as ideias pelo correio; é o bom-tom por assinatura. Que falta de espírito! E os maridos pagam-no (IDEM, p. 112).

Já Pinheiro Chagas, para comprovar sua tese sobre o modo equivocado com que a educação feminina estava sendo incentivada no país, coloca em confronto duas irmãs educadas de maneiras diferentes, que apresentavam logicamente também valores morais distintos. Leonor, educada no campo, livre das convenções sociais, prefigura o oposto da irmã Madalena, que se comportava de maneira requintada.

Leonor ia assim criada à lei da natureza; a sua educação física moral e intelectual faziam-na as ondas e os fraguedos; o infinito do mar ensinou-lhe a ideia de Deus, [...] a sua inteligência ali se desenvolveu, sem cultivo, não tendo por mestre senão a rude poesia desses selvagens ermos. Estou que as leitoras protestam contra semelhante educação e preveem na heroína uma aldeã bronca e malcriada; não tentarei dissuadi-las sem granjear, a custa da verdade, simpatias para Leonor. Tal ela era, assim, o retrato fielmente (CHAGAS, TBM, [1866] 1973, p. 26).

Há de ser para mim! - exclamou Madalena, chegando-lhe a sua vez de se alegrar. - É o meu querido piano, o meu toucador, o meu guarda-vestidos, os meus baús! [...].

O piano servirá para nós ambas. Sabes tocar piano?

- Eu! - exclamou Leonor espantada da pergunta.

- Deus me livre! Vi uma vez um piano em casa de Jorge e ouviu-o tocar a ele. Não gostei. Fazia muita bulha. Gosto mais de minha guitarra.

- Tu sabes tocar guitarra? - perguntou Madalena, abrindo uns olhos muito pasmados. [...]

Madalena não pode reprimir o riso ao ver a ingenuidade com que a irã se gabava de possuir uma prenda, que a ela parecia monstruosa. Desfechou uma gargalhada sonora e prolongada, que só terminou quando Leonor, primeiro espantada, depois ofendida, mostrou pelas lágrimas que lhe bailavam nos olhos, quanto se ressentia dos motejos de sua irmã (IDEM, p. $64)$.

Sempre em lados opostos, a primeira - leal, altruísta, amiga dos aldeões, mesmo com um ar melancólico - era carismática; já a irmã caçula só pensava em frivolidades e pouco se 
interessava pelos sentimentos dos outros, especialmente os de Leonor. Tanto assim que lhe rouba o noivo e não se arrepende, por acreditar que eles pertenciam a mundos tão distintos.

Mas a fatalidade que recai sobre Leonor não é só uma consequência do egoísmo e futilidade de Jorge e Madalena, mas da sua maneira excessiva de amar um homem que, na verdade, desejava uma noiva aos moldes da civilização requintada. Tudo aquilo que ela não era. E no momento em que Leonor percebe que a irmã preenchia os requisitos da mulher ideal para Jorge, ela passa a sentir involuntariamente ciúme e até mesmo inveja dessa educação que lhe fora negada.

\footnotetext{
Não posso conceber nem sequer o pensamento que nos podemos separar. Por ele calcaria aos pés os vínculos mais sagrados, por ele desprezaria todos, porque é ele a minha vida, o meu coração, a minha alma, porque toda me entreguei a este amor inefável! [...]

- Pensei ... vê que loucura a minha! ... Pensei que tu eras muito mais galante do que eu, que vinhas da cidade, prendada, sábia, formosa, enquanto eu sou uma pobre ignorante, que prefiro soletrar o livro do oceano, a folhear papéis, que nada sei senão amar... Acudiu-me então a ideia que eras bem mais digna do que eu de ser amada por Jorge...

- Pensei que Jorge podia reparar nisso mesmo que eu noto e esquecer a sua pobre selvagem para se enlevar nos aprimorados encantos da lisboeta. (CHAGAS, TBM, [1866] s.d, p. 57).
}

Por outro lado, o caráter frívolo de Madalena a torna incapaz de sentir remorso pelo que havia feito à irmã. Por isso, a culpa momentânea só aparece quando ela vê o seu mundo ruir com a morte do marido. A educação que Madalena recebera não a preparava para viver sem o governo e a proteção do marido. Diferente de Leonor que se vê sozinha, depois da traição da irmã e da morte do avô, mas assume o comando do solar. Na verdade, é a sua independência de espírito que a mantém viva.

Apesar de o narrador ter evidenciado todo o tempo uma Leonor viril, ao término do drama, este temperamento cede lugar a uma postura feminina indulgente e resignada, constituindo novamente a presença da mulher-anjo, uma heroína tipicamente romântica.

Levando-se em consideração o desfecho de suas heroínas, embora elas sejam as forças motrizes das narrativas, sucumbindo o herói do romance para um plano inferior, elas parecem ser consequências de suas malfadadas escolhas, como Tereza, que - mesmo tendo tudo na casa da madrinha - decide acompanhar Carlos, ambicionando luxo, riqueza e vida noturna. Assim, o desejo de conquistarem espaços de trânsito livre aos homens leva-as à sua própria ruína. Apesar de não enlouquecerem como as mulheres de Herculano, as de Chagas, geralmente, escolhem a clausura de suas casas ou de conventos, quando não morrem 
vitimadas pela fatalidade ou pelas mãos dos seus amantes. Em outra maneira mais subversiva, algumas preferem o suicídio a viver agenciadas pela Igreja.

Diante das muitas humanidades femininas apresentadas pela ficção de Pinheiro Chagas, parece-nos pouco provável que a maioria destas mulheres aqui desenhadas desempenhe o mesmo papel orientador e conselheiro imposto pela personagem dantesca. O que se depreende, depois do exposto, é que havia um despreparo entre as portuguesas, que eram, vulneravelmente, seduzidas por dois extremos totalmente contrários: de um lado, o catolicismo extremista e, de outro, as futilidades da vida à francesa: “[...] é o luxo, é o luxo! Origem de todos os males” (MACHADO, prefácio, FT, 1878, p. VII). Portanto, com tanta frivolidade no espírito, tal mulher estaria incapacitada de iluminar o caminho a seguir de gerações futuras. 


\subsection{A máscara vermelha e O juramento da Duquesa: A tragicomédia da Restauração}

Uma das razões para que muitos autores portugueses, participantes do conturbado século XIX, não sejam revisitados pela crítica e pelo público em geral deve-se, entre outros motivos, segundo Eduardo Lourenço (1982), à ausência de nacionalismo crítico em suas obras. Dito de outra forma, havia uma expectativa por escrituras que pudessem colocar em xeque a miséria nacional. Para tais escritores, alheios aos problemas do presente, que só falavam de um passado glorioso da nação, não restava outro espaço senão o silenciamento. Neste sentido, para a crítica, Pinheiro Chagas não só faz parte deste grupo, como o encabeça grotescamente, como a representatividade desse patriotismo retórico e oportunista, exercido pelos Brigadeiros Chagas.

Talvez Chagas não tivesse tido a mesma agressividade de estilo de seus opositores, que ridicularizavam a decadência de Portugal. Mas, por outro lado, há em seus romances (históricos ou não) comentários sobre a imagem de um Portugal em queda, que fora vitimado pela má governabilidade de seus monarcas. Chagas considera, como já indicamos, que o declínio nacional tivera início com a Dinastia de Avis, no reinado de D. Manuel, e seu auge na Dinastia de Bragança.

No parecer deste autor, o último período dinástico foi regido frouxamente, sendo excluído apenas o reinado de D. José, não por sua atuação régia, mas devido às intervenções pombalinas que buscaram a modernidade da nação. Segundo Chagas, por se colocar acima dos interesses nacionais, com a intenção de se conservarem no poder, os monarcas da Casa de Bragança doaram, barganharam e venderam a pátria aos jesuítas e ao estrangeiro. Entre as várias passagens que poderíamos usar para ilustrar a discussão, optamos por uma que não está nos romances históricos do autor, até como forma de confirmar essa morte nacional há muito anunciada. Alberto, personagem de A flor seca (1866), numa viagem a Veneza, não conseguia evitar o pensamento de similaridade entre as decadências da cidade que visitava e a de Portugal.

A pouco e pouco tinha caído numa profunda melancolia, e comparava involuntariamente a decadência nobre de Veneza com o mísero esfacelamento da minha pátria. Veneza é gigante, que desceu ao túmulo, envolto na sua armadura de mármore, e perante aquela maravilhosa campa descobre-se o mundo com respeito: Portugal também gigante, mais gigante ainda, arrojou-se à vala comum, e as nações desviam os olhos com tédio desse cadáver putrefato, coberto de vermes que o devoram (CHAGAS, AFS, [1866] 1904, p. 45). 
Ainda em As duas flores de sangue (1875), no capítulo intitulado A fuga para Sicília, novamente, o mesmo abandono de seus reis vindo de um aconselhamento dos ingleses. Por meio da dramatização deste episódio da História de Veneza, o narrador critica a aliança lusobritânica que só trouxera malefícios a Portugal e que, mais tarde, culminaria no Ultimatum inglês em 1890.

O rei e a rainha, decididos a fugir a todo custo, mandando abrir uma antiga passagem subterrânea, que do palácio comunicava com o porto, e por aí se escapavam misteriosamente, abandonando o seu povo à anarquia e ao inimigo, como dez anos depois o havia de fazer, em circunstâncias idênticas, um príncipe português (IDEM, p.160).

Sejam as ideias do decadentismo apresentadas de forma metafórica ou não, personagens como Alberto são verdadeiros porta-vozes do autor, que, inconformados com o destino português, vão imprimindo na narrativa recorrentes imagens e concepções de uma pátria em ruína moral e cultural. Melancolicamente inertes, as personagens de seus romances em geral fazem alusão a uma nação entregue à própria sorte, sem comando, sempre sujeitada aos interesses dinásticos e jesuíticos.

E o período da Restauração não teve um cenário diferente. Apesar de o movimento restaurador celebrar a reconquista do país e a reforma nacional, a História nos conta, por outro lado, que foi um período de estrema instabilidade econômica e política. Além disso, havia ainda em Portugal pessoas ressentidas ligadas à nobreza e ao clero, que se viram prejudicadas com a perda de prestígios, que tinham na Dinastia filipina. E associado a isso, depois de 1 de Dezembro de 1640, o governo espanhol tentou insistentemente, sob todos os meios, destituir D. João IV do trono português. Com todos estes ingredientes, era de se esperar um clima de desconfiança e de insegurança na corte, pois estavam em jogo não só os importantes cargos no Estado, mas a própria vida. Se o rei estava sob constante pressão de ser traído, isso refletia diretamente sobre seus súditos, que viam no grupo adversário uma constante ameaça. Assim, o ódio, a inveja e as intrigas motivavam as alianças, que tramavam a queda dos oponentes, pelo fato de estes terem um lugar de destaque junto ao monarca.

Depois de exposto o ânimo da época, a seguir, propomos discutir como Pinheiro Chagas considera que este período foi mais um dentre outros da História que favoreceu o declínio da nação, pois o monarca em sua vaidade só se preocupava em mostrar ao estrangeiro como sabia decepar as cabeças dos traidores. 


\subsubsection{O enredo: teatralidade e realismo}

Para Pinheiro Chagas, o Portugal seiscentista era uma autêntica tragicomédia. A banalidade e a facilidade com que forjavam os processos de incriminação dos pseudoconspiradores ajudaram a criar um cenário de horrores, ao mesmo tempo trágico e cômico. Segundo Massaud Moisés (2004), a tragicomédia seria a combinação de componentes trágicos (assunto e personagens) e cômicos (incidentes e desfecho). Contudo, a partir do século XIX com a frequente fusão dos gêneros, os textos teatrais que misturavam o riso (cômico) e a lágrima (trágico) passaram a ser conhecidos como drama. Assim, antes de iniciarmos a análise de A máscara vermelha e O juramento da Duquesa, a primeira postura a ser tomada é tentar vê-los como um único drama. Isso porque podemos extrair deste enredo os elementos essenciais que o caracterizariam como tragicômico. Do trágico, poder-se-ia destacar a condenação dos conjurados acusados de alta traição, enquanto que a maneira como transformavam as decapitações em verdadeiros espetáculos seria o desenlace cômico. Ou numa leitura mais ampla, o movimento restauracionista que deveria promover o avanço de Portugal acabaria por precipitar a sua derrocada.

Outra medida é ter nítido que, embora Pedro Bonete ${ }^{110}$ e os integrantes da família de Vila Real tenham existido realmente, esses dois romances históricos apresentam uma intriga romântica. Por isso, nos livros, essas personalidades são totalmente inventadas no momento em que o narrador reconstrói o período da conspiração contra o rei D. João IV.

Sob estes termos, na primeira parte desta seção, tentaremos demonstrar que Pinheiro Chagas irá se utilizar dos elementos cênicos na composição de A máscara vermelha e, sua continuação, O juramento da Duquesa com o objetivo de dar mais realismo à sua narração. Para depois, apresentar o assunto da Restauração numa perspectiva tragicômica.

Dito isso, cumpre agora notar que, embora haja um processo de silenciamento sobre as obras de Manuel Pinheiro Chagas, esses dois romances históricos fogem à regra e aparecem citados como os títulos mais conhecidos do autor. Nesse aspecto, parece que, de algum modo, eles resistiram aos ditames do tempo e do espaço ${ }^{111}$. Possivelmente, uma das causas teria sido a curiosidade do público aguçada pela história sobre a Lenda do Penedo da Saudade, que faz

\footnotetext{
110 Ver Vólaro, s.d, p.10. Embora a atuação ardilosa de Pedro Bonete na narrativa faça-o parecer uma personagem inventada, ele realmente existiu e manteve relações diretas com Francisco de Lucena. Segundo Carlos Henrique Vólaro, nos documentos da época, há informações pertinentes sobre "um tenente de nome Pedro Bonete [que] fora capturado nas fronteiras do Alentejo, sob a suspeita de espionagem, e entregue ao Conde de Óbidos”.

${ }^{111}$ Com a republicação de $A$ corte de D. João V em 2002, este romance se insere no grupo da literatura revisitada de Pinheiro Chagas.
} 
parte da memória cultural. Conta a tradição que, todos os dias depois da morte do Duque de Caminha, Juliana chorava a sua ausência no referido penhasco. Conhecida um resumo dessa história, vejamos, então agora, a outra que Pinheiro Chagas vai nos narrar.

A primeira parte do drama conta-nos a história de um anti-herói, Pedro Bonete, espanhol dissimulado, violento e astuto que se casa intencionalmente com a personagem inventada Inês Mendes, depois de tê-la desonrado. É evidente sua ambição em ascender e de se manter no círculo da nobreza. Mas não fica só nisso, pois a personagem possui um caráter egocêntrico e, à medida que vai convivendo com a fidalguia, começa a ambicionar a vida que eles possuem, inclusive suas mulheres. Na verdade, dois episódios são decisivos para se entender o comportamento dele na narrativa: a tentativa de roubo frustrado ao duque, em que o fidalgo intervém na sua soltura, e o momento em que ele conhece os aposentos da duquesa e a ela própria. Não há dúvidas de que todo o seu investimento na história reside não só no desejo de viver, mas viver bem, porque ele quer obter posses e poder. Por isso, Pedro Bonete, inicialmente, conspira com o grupo até ver qual proveito poderia tirar disso. Procura então a Duquesa de Caminha na intenção de transformá-la em sua amante, sendo que em troca ele não denunciaria o seu marido às autoridades de Portugal. Ela repudia a proposta e o humilha. Colérico, o espanhol decide delatar os conjurados ao secretário de Estado Francisco de Lucena. No segundo momento da trama, a Duquesa de Caminha com a ajuda de D. João da Costa prepara e executa a vingança contra os responsáveis pela morte injusta do seu marido.

O período da Restauração escolhido por Pinheiro Chagas é um dos mais emblemáticos na reafirmação de Portugal enquanto nação. Contudo, o objetivo do romancista não é

[...]celebrar os grandes feitos nas campanhas da Restauração, mas de narrar
os enredos da corte, as calúnias, as traições que se desenrolavam no reverso
desse quadro brilhante das épicas pelejas e de sobre-humanas façanhas. Mas
se também isto é história, também isto é mister que se conte e não se colhe
menos proveito da narrativa das fraquezas e dos defeitos dos nossos
antepassados, que são para nós amargas lições, do que da narrativa das suas
virtudes e das suas glórias, que são para nós glorioso incitamento
(CHAGAS, OJD, [1873] s.d, p. 90).

Para Pinheiro Chagas, a Dinastia de Bragança foi desde o início que semeou a degeneração nacional. Veremos que, na sua concepção, a Restauração não indicava um tempo de plena liberdade. Pelo contrário, com a presença dos jesuítas no poder e na educação nacional e com uma casa aristocrática em ruínas e desorientada, Portugal continuava numa direção descendente. A lei que imperava nessa época era do ressentimento, da desconfiança e das intrigas, e inocentes, como o Duque de Caminha e Francisco de Lucena, foram 
condenados e decapitados sob o falso crime de conspiração. É essa a história que o narrador deseja contar: "Nessa disputa andavam [os procuradores reivindicando um pagamento mais igualitário do tributo à coroa de acordo com a classe social], quando levantamos o pano para $o$ novo drama que vamos narrar” (CHAGAS, OJD, [1873] s.d, p. 21, grifo nosso). Assim, esta abertura, com a qual começa o segundo ato deste drama, demonstra que não só o narrador ${ }^{112}$ dirige-se ao leitor, utilizando-se de um vocabulário cênico, mas, de um modo geral, as personagens se comportam como num tablado de teatro.

Mas para a composição de seus romances históricos, Chagas não leva só em consideração a essência dramática. Além dessa, é necessário que o gênero apresente três elementos fundamentais ${ }^{113}$ : Paixões, caracteres e ação. Com eles, pretendia-se reproduzir um efeito visual, possibilitando realmente a inserção do leitor na narrativa, de forma que o passado lhe parecesse ressuscitado. Pensando-se nestas bases, se - para Chagas - o ofício do poeta era duplamente mais difícil do que o do historiador, para este tipo de romancista histórico, então, era triplamente mais árduo. Isso porque, além do domínio da História, o escritor deveria ter gênio inventivo e ainda procurar encenar o passado, de forma que a perspectiva autoral e o jogo de luz e sombra pudessem contribuir para “[...] desprender os vultos da tela e dar-lhes movimento [...]” (CHAGAS, NEC, [1867] 1890, p. 260).

A respeito disso, mereceriam referências as ideias de Maria Leonor Machado de Sousa, que credita ser tal hibridez de gêneros uma fina tendência dos românticos para “[...] transmitirem os sentimentos das suas personagens e [...] darem maior colorido às suas descrições” (SOUSA in: GAMA, 1981, p. 25). Tomando como norte as ideias de Chagas e a elucidação da crítica posterior, propomos evidenciar quanto ao estilo, nos romances históricos A máscara vermelha e O juramento da Duquesa, a linguagem e a técnica da dramaturgia utilizadas com fins específicos de produzir movimento à trama, ajudando a criar uma ilusão do real, ou melhor, dando vida ao quadro inerte do passado perante um leitor tão distanciado no tempo.

\footnotetext{
${ }^{112}$ Outros exemplos podem ser visualizados nas seguintes obras e paginação: (AMV, p. 74): "Esta cena da estalagem, o que estava sendo era mais fértil em reconhecimentos do que o quinto ato de um melodrama". I (OGM, p. 198): “[...] foi horroroso o espetáculo [...]”. / (AJVR, p. 106): “[...] E agora que nos aproximamos da tragédia [...]". / (AMB, p. 21): "Se os leitores no-lo permitem, não seguiremos a história narrada pelo capitão, poremos em cena a nosso modo, humildemente, no palco estreito do romance, as peripécias que ele referiu". / (AVG, p. 168): "O novo ator, cuja a chegada havia produzido [...]". / (AMB, p. 40): "[...] quando me iludiu covardemente, quando representava comigo a comédia do amor, porque tudo aí é comédia, o amor e o nome, o recato e a gravidade $[. .]$.$" .$

${ }^{113}$ As indicações sobre a sua concepção de romance histórico estão em informações dispersas em seus artigos críticos, compilados em dois livros de crítica: Ensaios Críticos e Novos Ensaios Críticos, respectivamente de 1866 e 1867, essencialmente nos artigos destinados à análise dos romances históricos de Camilo Castelo Branco, Arnaldo Gama e Silva Gaio.
} 
Contudo, antes de passarmos para esta discussão, será inevitável uma introdução sobre algumas particularidades do gênero dramático, que é essencialmente um texto de representação. Quando se fala da essência dramática, já se vislumbra a questão da minimização da interferência do narrador. Por outro lado, esta particularidade do teatro transportada para o romance histórico, de início, estabelece um problema, pois existe uma necessidade intrínseca deste gênero concernente ao descritivismo histórico. Se, por um lado, estas verdadeiras pausas na diegese travam a ação romanesca, fazendo-a perder unidade, por outro, elas habilitam os leitores a compreenderem o panorama épico. Neste sentido, como o romancista dramático, se assim podemos considerá-lo, consegue manter o dinamismo e a harmonia entre os elementos da trama sem prejudicar o caráter próprio de instruir o leitor? Certamente, suprimindo a voz narrativa e transferindo o máximo possível da descrição histórica para a linguagem da personagem, provocando com isso uma visão mais realística do episódio. No entanto, devemos esclarecer que por este caráter didático do romance histórico é quase impossível a supressão do narrador, como se pode constatar pela presença de longos trechos narrativos que há na ficção de Pinheiro Chagas, por mais que ele forje situações em que pareçam que o narrador está silenciado. De certa forma, ele só consegue em parte isso quando se utiliza das técnicas do gênero dramático.

E, por que este gênero, e não outro?

Hegel, seguidor do pensamento aristotélico ${ }^{114}$, considera que o drama é a mímesis da ação. O gênero dramático seria, em sua opinião, o mais completo entre todos, pois

a poesia dramática, por sua vez, que reúne a objetividade épica e a subjetividade lírica, é um gênero superior, pois apresenta uma ação circunscrita como sendo uma ação real, cujo resultado deriva tanto do caráter íntimo das personagens que a efetuam, como da natureza substancial dos fins e conflitos que a acompanham ou que [a] provocam (HEGEL, [18..] 1964, p. 373).

Apesar da presença dos princípios épicos (objetividade ligada ao narrativo) e líricos (subjetividade relacionada aos estados da alma) no drama, Hegel ressalta que, quando um indivíduo exerce uma ação real numa determinada situação, não há a necessidade de uma voz

\footnotetext{
${ }^{114}$ Livro que discute sobre o processo mimético e da verossimilhança. A Arte Poética, de Aristóteles, é composta de vinte e sete capítulos, que apresentam conceitos e exemplos sobre os gêneros literários, a tragédia, a epopeia. O terceiro tipo, a comédia, desapareceu completamente. Tratando especificamente da tragédia, no capítulo VI, o filósofo grego considera que a imitação de uma ação é uma combinação de atos e que só por meio do agir se conheceria o verdadeiro caráter e o pensamento das personagens.
} 
narrativa para descrevê-lo nem ao seu entorno. Por outro lado, requer, sim, que “[...] a obra de arte ofereça uma aparência verdadeiramente viva, o condicionalismo de completa representação cênica” (IDEM, p. 373). Trata-se, portanto, da ação do personagem, centro da representação dramática, por meio da qual nós conhecemos realmente o personagem e os acontecimentos que se desenrolam. Resumindo, como bem diz o filósofo alemão, “[...] no drama, as situações só têm sentido e valor pela ação das personagens, pelos fins que estas perseguem e pelos caracteres que assim revelam” (IDEM, p. 78).

Contudo, para que haja a movimentação dramática, é necessária a presença de dois aspectos, o caráter e o desejo. Este pensamento inscrito na Estética, de Hegel, considera que ambos sejam impulsionadores da ação, devendo ter “[...] uma ideia clara e precisa do que constitui o divino motor das paixões, dos conflitos e dos destinos humanos, seja esse motor nominado ou inominado na obra teatral” (HEGEL, [18?] 1964, p. 382).

Nessa mesma linha de raciocínio, Käte Hamburger (1975), colocando em confronto a literatura dramática e a épica, ${ }^{115}$ assinala que a primeira está para o encenável assim como a segunda está para a narração. A presença do elemento mímico equivaleria à ideia de que a construção dos personagens só se efetiva por meio de seu diálogo. Dito de outra maneira, “[...] a limitação à produção dialógica de personagens traz consigo a sua possibilidade mímica: os personagens representados apenas pela sua fala criam-se a si mesmos por ela” (HAMBURGER, 1975, p.139-140). Em reforço a essas considerações últimas, Lígia Chiappini Leite (2001) comenta que o princípio da objetividade que a narrativa utiliza-se para contar-se a si mesma, sem a existência de um narrador, é basicamente de intervenção realista. Neste sentido, a informação ao leitor é limitada e mediada pelo diálogo das personagens, pois - sendo breve ou longa a sua fala - será ela quem promoverá a interpretação da narrativa por parte de quem lê, como complementa Käte Hamburger.

A fórmula pela qual a palavra se torna personagem é a expressão da objetividade, da reificabilidade dos personagens dramáticos, que se constitui pelo desaparecimento da função narrativa e a distribuição da matéria representada entre personagens que se representam e expressam livremente. Com isso, eles ganham o aspecto, que é também o das pessoas reais no espaço da realidade física, dos 'outros', das pessoas que existem além de mim, que eu vejo, ouço e com quem falo. Para mim, são objetos, coisas, embora se refiram a si mesmos com 'eu', e nunca posso ganhar deles uma imagem completa. Posso saber sobre eles somente o que eles me revelam seja por palavras, seja por ações (sendo que as últimas podem

\footnotetext{
${ }^{115}$ Entende-se o termo épico como o mesmo que narrativo. Narrar passou a ser para o homem primitivo uma necessidade de relatar aos seus semelhantes suas experiências, já que sua existência corria perigo iminente no ambiente hostil em que vivia.
} 
eventualmente alterar a imagem transmitida por palavras) (HAMBURGER, 1975, p. 142).

Numa ilustração do que tentamos teoricamente organizar, o narrador de O terremoto de Lisboa, desejando esclarecer a inocência de Luiz Correia em relação à vivacidade de Terezinha, que era indiferente ao seu amor, tece o seguinte comentário: "Para que havemos de prosseguir em mais longa descrição? Ponhamos em cena os personagens, e eles mesmos farão entrar o leitor na confidência dos seus sentimentos e das suas paixões [...]” (CHAGAS, OTL, 1874, p. 39).

No entanto, o caso se torna mais sério quando falamos das personagens históricas, pois a aceitação de suas ações como verossímeis e também o reconhecimento de sua individualidade estariam vinculados ao saber histórico do público, que ainda teria de estar nivelado com o do autor, para que isso pudesse ocorrer. Sem isso, o leitor desavisado não entende, por exemplo, a presença de Francisco Manuel de Melo, autor de O fidalgo aprendiz $^{116}$, no capítulo intitulado A tragicomédia dos jesuítas. A sua aparição e a citação desta peça é essencial porque além de reforçar a pobreza do teatro jesuítico quanto à verdade humana. Por outro lado, enfatiza a ideia de falência daquela sociedade portuguesa que conspirava e fazia intrigas para se manter ao lado do poder real. Este tipo de caráter se aproxima ao de outro candidato a fidalgo, D. Gil Cogominho, que levava tão a sério o propósito de elevação pessoal, que suas ações e intenções beiravam o ridículo. Assim, a presença deste específico trecho da peça de D. Francisco Manuel na obra de Chagas, além de contextualizar o período, apresentando a literatura da época como um elemento da cor local, ainda aproveita para criticar veladamente a questão das máscaras sociais, reafirmando que as relações na vida são tão ilusórias quanto no teatro.

Além das aproximações que são feitas, ainda há um episódio em que Iria, uma personagem inventada, dramatiza um trecho de $O$ fidalgo aprendiz. Esta cena passa a ser também, para o narrador, uma oportunidade de mostrar seu conhecimento literário não só local, mas de literaturas estrangeiras do período, quando faz alusão à teoria de Nicolas

\footnotetext{
${ }^{116}$ Ver Oliveira, s.d, p. 25-26. O crítico sugere que Le bourgeois gentilhomme, de Molière, é uma imitação desta peça de D. Francisco Manuel devido à notória semelhança entre ambas e por causa do fato de que a primeira tenha sido publicada em 1670 e a de D. Francisco Manuel em 1646. O crítico finaliza a constatação com a seguinte afirmativa: "É possível que Molière conhecesse diretamente a peça portuguesa, impressa nas Obras métricas, de que a primeira e a terceira parte são em castelhano, sabido como é que constantemente recorreu à literatura espanhola, à procura de sugestões e modelos. E, se não leu, é provável que dela tivesse notícia, ou indiretamente, ou pelo próprio D. Francisco Manuel, quando em missão diplomática esteve em Paris, em 1663 e 1665 ".
} 
Boileau-Despréaux ${ }^{117}$ sobre dramaturgia encontrada na sua Arte poética: “[...] Iria, falando umas vezes com a sua voz natural, outras dando-lhe umas entonações masculinas, e sempre com verdadeiro sal cômico, recitou a célebre cena do auto [...]” (CHAGAS, OJD, [1873] s.d, p. 110, grifo nosso). Esta passagem pode ser ainda considerada como uma prova do anacronismo cultural do narrador, pois só no prefácio de 1701, como elucida Célia Berretini (1979), Despréaux irá considerar que o conceito de obra ideal deve ter “[...] um certo sal próprio a estimular o gosto geral dos homens [...], um não sei o que, que se pode muito mais sentir do que dizer” (DESPRÉAUX, [16?] apud BERRETTINI, 1979, p. 12). É claro que, além disso, este intertexto em $O$ juramento da Duquesa não deixa de estabelecer conceitos metapoéticos em relação à arte de representar. Boileau, no mesmo texto que vimos comentando, adverte que o ator deve atuar como se brincasse, de forma natural, mas ao mesmo tempo deve ser guiado pela razão, com o propósito final de desenlaçar o nó do drama. Assim, entende que a exibição do ator deve fazer que “[...] nossos olhos vivam, ajam e falem” (IDEM, p. 52) ${ }^{118}$. Novamente surge a ideia de fazer com que o leitor se perceba como parte integrante da história, objetivo que Chagas, de certa forma, persegue quando se utiliza dos elementos dramáticos no seu romance histórico.

Mas outro recurso recorrente no gênero para dar veracidade ao narrado é colocar num mesmo plano narrativo personagens inventadas com as históricas, como aparece aqui o escritor seiscentista D. Francisco Manuel de Melo. Contudo, como já indicamos, embora sejam personagens históricas isso não as excluem de, nas mãos dos autores, serem submetidas também a situações inventadas, principalmente no convívio com as imaginárias, tudo em prol de uma intriga interessante e convincente. Só não podemos nos esquecer de que as invenções biográficas apenas são possíveis nos períodos aos quais a História não faz referência, geralmente em períodos ligados à vida íntima dessas personalidades.

\footnotetext{
${ }^{117}$ Idem s.d, p. 123. É feita alusão a outra preposição de Boileau: “Le vrai peut quelquefois n'etre pas vraisemblable [...], [isto é] [...], à verdade uma falsidade mais verossímil”, expressão associada às adulterações do processo de investigação do caso que apurava se Francisco Lucena era traidor ou não da pátria. A frase do pensador e poeta francês do século XVII confere à razão um espaço importante na qualidade da obra, sendo que só por meio da racionalidade se alcançam o bom senso, o equilíbrio, a adequação e a clareza, elementos inerentes à poética. Trazendo isso para a situação em que se contextualiza tal noção de acordo com as ideias de Boileau, o narrador ressalta a vaidade e a prepotência do grupo que investigava o ato, que - sem racionalizar o processo buscava apenas os culpados e não o esclarecimento real dos fatos.

${ }^{118}$ Ver Lukács, 2011, p. 34. György Lukács comenta que já em seu tempo Boileau era cético “[...] em relação aos romances históricos de seus contemporâneos [que tratavam a história apenas como pano de fundo], [pois Boileau] considera[va] importante apenas a verdade social e psicológica das personagens, e exige que um senhor ame de modo diferente de um pastor" (LUKÁCS, 2011, p. 34). Levando-se em consideração as ideias que são recuperadas do crítico francês, é provável que Chagas estivesse discutindo que o princípio realístico é muito mais do que um simples descritivismo do ambiente. Na verdade, como também entende Machado de Assis (1878), o único realismo que importa é aquele que reside na verdade da natureza humana.
} 
Exemplificando o discutido, uma das passagens mais enigmáticas de O Major Napoleão corresponde à dramatização da revelação da morte do Marquês de Loulé ${ }^{119}$ por uma bruxa de Smolenko. Certamente, a presença insólita dessa personagem atende à necessidade, na composição histórica, do elemento romântico ou inventivo. Tanto assim que Pinheiro Chagas, em uma de suas poucas notas de rodapé no livro, adverte o leitor de prováveis estranhezas quanto a este episódio. Contudo, para contornar a efabulação nítida do fato histórico - atitude que sempre condenou, principalmente nos livros de Alexandre Dumas -, Chagas atribui a interferência do fantástico no reconto às memórias do velho e crédulo Major Napoleão. ${ }^{120}$

O meu bom e malogrado amigo Silva Gayo, no seu formoso romance Mário, pôs muito em dúvida o assassínio do marquês de Loulé, e se não deixou completamente demonstrada a falsidade da imputação que em tempo se fizera a um alto personagem, pelo menos impossibilitou o historiador de dar como assente o fato, contra o qual o distinto romancista juntou uma grande massa de argumentos apreciáveis.

O romance, e principalmente o romance fantástico, tem deveres menos severos. À feiticeira russa não era infalível. Aproveitando uma tradição dramática, não lhe dei foros de histórica. No texto, conservei à profecia da feiticeira um certo vago, para impedir interpretações, que poderiam ser caluniosas da memória de um dos personagens das nossas lutas políticas. Além disso, esta nota serve para atestar aos leitores, que, adotando a suposição do assassino do marquês de Loulé, não me coloquei ao lado dos que juram na veracidade do fato, e apenas aproveitei, dos diversos modos porque é narrada a morte do marquês, aquele que melhor quadrava a índole do meu romancinho (CHAGAS, OMN, [1867] s.d, p. 47).

O fragmento apresenta duas forças que nos conduzem ao discurso de Pinheiro Chagas, a do historiador e a do romancista, prevalecendo a deste último, ao considerar não ser prioridade do drama suspender a ação para esclarecer suposições. Termina o trecho, surpreendentemente, assumindo que se utilizou de um dado obscuro da História em favor da intriga de seu romance. Seria, portanto, este trecho uma das contradições cometidas por parte do autor de $O$ juramento da Duquesa quanto ao processo de criação do romance histórico? Pensamos que não. As suas recorrentes reprovações consistiam na forma como era corrompida a verdade histórica por parte de alguns escritores que, por falta de domínio da

\footnotetext{
${ }^{119}$ Por ser um fato histórico de pouco domínio dos historiadores, Pinheiro Chagas de certa forma se aproveita da lacuna para introduzir elementos romanescos para a história ficar mais atrativa ao leitor. Um dos muitos exemplos passíveis de referência refere-se aos filhos bastardos de D. João V (figuras inventadas): D. Carlos e Terezinha, que constituem a intriga central do romance histórico $O$ terremoto de Lisboa.

${ }^{120} \mathrm{Cf}$. Chagas, [1867] s.d, p. 84. Em outra nota mais à frente, Pinheiro Chagas adverte que "a narrativa que se vai ler é um pouco fantástica; mas devo dizer, para me salvar de responsabilidades, que o digno major acreditava piamente nela, como acreditava no caso da feiticeira de Smolenko”.
} 
historiografia, recorriam tanto às peripécias, no lugar de recriar o drama histórico, que acabavam por distorcer a realidade empírica do tempo que tentavam retratar. Por outro lado, o romancista - que se preocupava demasiadamente em detalhar a época - deparava-se com outro problema na diegese: a perda de unidade e de ação no romance, como acontece em um dos “senões” à escritura de Arnaldo Gama feito por Chagas. Nos seus comentários, este considera que a falha da Última Dona de S. Nicolau estaria na subjugação da poesia pela análise histórica, o que aproximaria a referida narrativa mais de um estudo histórico do que de um romance.

Nessa medida, as inúmeras informações históricas sobre o período romanceado acabam por criar uma ruptura no processo evolutivo da ação dramática, revelando de certa forma sua estagnação. Por isso, quando evita se delongar na descrição histórica ou legitimar o recorte escolhido sobre o período histórico, o narrador esclarece que “[...] não tentamos contar a história do domínio francês em Portugal. Através dessa imensa tragédia do destino napoleônico, seguimos apenas as peripécias que devem servir de esplêndido quadro ao nosso modesto drama” (CHAGAS, OGM [1872] 1874, p. 133-134). Em outro momento, sabendo das preferências do leitor empírico pelas peripécias romanescas, mas tendo que esclarecer alguns pontos da História necessários ao entendimento da trama, ${ }^{121}$ o narrador se solidariza com ele e lhe pede paciência. Em outras vezes, até elogia a sua sagacidade. ${ }^{122}$

Dadas estas explicações, indispensáveis para a boa inteligência da narrativa, pediremos aos leitores benévolos que nos acompanhem a uma das salas do palácio do Marquês de Vila Real, a cuja porta, fechada por pesados reposteiros, vela do lado de fora, um criado de confiança do marquês.

Na sala estão apenas dois homens, o velho fidalgo que já conhecemos, e um eclesiástico da alta hierarquia, homem de idade, de fisionomia antipática, onde apenas se leem a ambição mesquinha e o orgulho inepto (CHAGAS, $A M V$, [1873] s.d, p. 86).

\footnotetext{
${ }^{121}$ Algumas interpelações ao leitor aproximam-se a súplicas para a inclusão de explicações historiográficas na trama, justificando-as como elucidação do fato relatado ou para inserção de novas personagens: "Um homem havia de quem, mais do que de todos os outros, Maurício de Nassau se receava. Esse homem era João Fernandes Vieira [conspirador brasileiro, que lutava para a independência de Pernambuco do jugo do estrangeiro, principalmente dos holandeses]. Ao fazermos entrar em cena vulto célebre dos nossos anais, é preciso que lhe consagremos algumas páginas de introdução” (CHAGAS, ACP, [1866] 1870, p. 104-105. Mas em outros casos, o narrador dá livre arbítrio para o leitor ler ou não as introduções históricas, como ocorre no mesmo livro do qual vimos apontando trechos: “[...] Procuramos dar assim uma tal ou qual unidade a estes quadros soltos da história brasileira. O leitor, que num livro deste gênero procura apenas peripécias e aventuras, pode saltar os três primeiros capítulos, e entrar imediatamente em pleno enredo".

${ }^{122}$ Ver Chagas OJD, [183] s.d, p. 123: "O que sucedera, pois? Sucedera o que o leitor facilmente previu, depois de ter assistido à longa conversação de D. Pedro com D. João da Costa”. Já em OGM, [1872] 1874, p. 99: “Os leitores já perceberam o plano do conde de Vila Velha. Sentindo a urgência de embarcar, não achando modo de prevenir a polícia para dela reclamar proteção, lembrara-se de súbito de ir a um teatro onde encontraria muito provavelmente soldados desse corpo, e obteria assim a escolta que estava sendo indispensável”.
} 
Selado o pacto de leitura entre narrador e leitor, percebam como ele segura a mão do leitor e o direciona ao outro compartimento da casa, em que estão conversando algumas personagens, movendo com isso o quadro.

Em outra situação, a voz narrativa parece se esconder por trás do olhar cobiçoso de Pedro Bonete para que se possa, com isso, conhecer o luxo dos aposentos da duquesa. A descrição se prende entre os ornatos em ouro e cristal do ambiente e os acessórios femininos (vestidos, meias de sedas e sapatos), que não deixam de denunciar a lascívia do catalão.

- Pois que entre! Que entre! Disse a duquesa.

O Duque de Caminha voltou-se, fez um sinal a D. Pedro, e este entrou no toucador.

Era uma sala esplêndida, toda forrada de espelhos de Veneza e Holanda, e adornada com as mil encantadoras futilidades, que sempre constituíram o arsenal das damas, [...] o camarim da Duquesa de Caminha estava cheio de jarras, de redomas de cristal, de ricas bocetas, de cofres de tartaruga, de caixas de luvas, de fitas e de pequenos relógios esmaltados da Inglaterra. [...] Os guarda-roupas de Holanda, alguns dos quais, entreabertos, mostravam que havia pouco tempo que se tinham tirado de dentro delas os vestidos magníficos para a duquesa e para Inês, substituídos pelos trajos mais modestos que habitualmente vestiam. O desalinho revelava que as camareiras se tinham apressado para que os convidados não tivessem de esperar muito tempo. As meias de seda com renda de ouro, [...] os sapatos de âmbar que a duquesa trocara por uns ricos chapins com fivelas e topes de pedras preciosas, estavam amontoados em desordem no fundo dos guardaroupas.

E tudo era pouco decerto para tanta beleza. [...]

$\mathrm{O}$ vestido de seda azul com as saias ornadas de torçais custosos, e golpeadas de mosqueta, dava um realce vivíssimo à loura formosura. [...]

D. Pedro, ao entrar, parou atônito de tanta formosura(CHAGAS, AMV [1873] s.d, p. 118-119).

Neste sentido, o narrador/encenador se utiliza não apenas do olhar de algumas entidades ficcionais para evitar o desgaste da descrição direta, como ele coloca nas falas de seus títeres a sua cosmovisão, tirando um pouco a responsabilidade da carga discursiva que recai sobre si. Isso na linguagem cênica se denomina didascália, que consiste na atribuição de falas e de suas circunstâncias determinadas pelo autor. Mesmo sendo responsabilidade do autor de escolher ações e gestos das personagens, Anne Ubersfeld (2004) salienta que a escritura teatral não pode ser nunca considerada como subjetiva. Tal defesa se orienta pelo fato de que, se o autor utiliza da máscara da personagem para dizer o que quer dizer, então, o diálogo é feito de muitas vozes, com seus diversos pontos de vista. 
Outra técnica, muito ligada à subjetividade do plano de criação, é a mise-en-scène ${ }^{123}$, que pode ajudar o leitor a compreender qual história pretende escrever o romancista, se a dos vencedores (olhar de cima para baixo) ou a dos vencidos (num sentido inverso ao primeiro). Além disso, outros meios - como o processo de exclusão ou de inserção de elementos épicos e o destaque que se dá aos vultos históricos - podem ajudar no esclarecimento da visão de História e de mundo de quem narra.

Na mise-en-scène, existem os jogos de sombras e o da luz. A atividade de narrar e descrever faz parte dos jogos de sombras, e a luz estaria na perspectiva do romancista. Esta última consistiria, portanto, no foco que se dá à cena e, em escala maior, na escolha deste e não daquele fato histórico.

Compreendido isso, vejamos, portanto, a presença da sombra e da luz estrategicamente estabelecida numa cena em que a Duquesa de Caminha se depara pela primeira vez com o cadafalso. Reparem como a sua visão inicialmente ampla vai se restringindo até iluminar somente o cepo (o particular), que lhe causa terror, pois representa a morte decretada ao marido.

Entretanto a duquesa, acompanhada por Inês, chegara à porta da rua, onde a esperava uma cadeirinha. Inês fez sinal aos criados, que se aproximaram rapidamente, mas não puderam fazê-lo ainda assim tão depressa, que a atenção da duquesa fosse atraída pelo burburinho dos operários que trabalhavam junto da casa fatal e pela trêmula luz de alguns archotes, que se agitavam rapidamente de um para outro lado. A duquesa olhou e viu uma construção sinistra [visão do todo], uma plataforma que se ligava com as janelas da sala, de onde ela acabara de sair, depois de um tablado, onde à luz vermelha de um archote [vai restringindo o foco de maneira descendente] alguns operários colocavam um cepo que outros revestiam de veludo negro [até chegar a uma aproximação em close-up]. A Duquesa de Caminha não percebeu ou recusou-se a perceber a significação daqueles sinistros preparativos. Pálida, aterrada, mas com os olhos magneticamente cravados naquela visão funérea, resistindo aos esforços de Inês, que procurava metê-la na cadeirinha, perguntou com voz balbuciante:

- O que é isto?

- Não sei, senhora duquesa; depois perguntaremos, mas vamos depressa para casa. Estais incomodada, decerto?

- Ah! Exclamou a pobre senhora, confirmada nas suas terríveis apreensões pelo tremor das palavras de Inês. Ah! Bem sei! É o cadafalso! É o cepo

\footnotetext{
${ }^{123}$ Ver Chagas, NEC, [1867] 1890, p. 260. Para o crítico, o romancista no romance dramático histórico seria o encenador, ou seja, tendo "a mise-en-scène por conta do escritor": [...] Como os personagens se movem naqueles ares cheios de vida; pinta-me de relance as flores angolenses, as solidões da África, e eu sinto-me transportado aos trópicos, e vejo e sinto o que Mário vê, e o que Mário sente [...] ” (CHAGAS, NEC, [1867] 1890, p. 263, grifo nosso). Estas ideias são defendidas no ensaio sobre Mário, do Dr. Silva Gaio.
} 
sinistro! É aqui que querem matar o meu marido! (CHAGAS, AMV, [1873] s.d, p. 185).

Esta construção cinética só foi possível graças ao sombreamento dado ao cenário à medida que o foco de Juliana recai apenas no objeto iluminado, que prenunciava a morte do marido. Com o acréscimo de que o leitor vê a cena pela perspectiva da personagem, isto ajuda a reforçar mais o seu realismo. Esta estratégia autoral relaciona-se ao conceito de intencionalidade de mímesis estabelecido por Barbara Foley (1986). No parecer desta autora, em toda a ficção há um contrato tácito entre o escritor e o leitor, aquele que compartilha o simulacro e por meio do qual este é convidado a aceitá-lo e que, por seu turno, firma a aceitação. Por outro lado, quando se consegue que o leitor interaja com a narrativa, Emil Staiger (1972) entende que houve a efetivação da empatia, que tem sua força no pathos. Especificamente na questão da essência dramática, para o referido estudioso, ela se divide em pathos e no problema. O primeiro tendo como particularidade comover o leitor, envolvendo-o de tal forma que ele se sinta parte da história, chegando até a solidarizar-se com as personagens nos seus momentos de dor e angústia. Por outro lado, o problema seria a proposição, aquilo que o autor do texto dramático se propõe a resolver. Assim, por meio da junção desses dois elementos, promove-se o movimento do entrecho, conduzindo sempre a ação para adiante, para o futuro, que equivale ao desfecho.

Esta cumplicidade parece ocorrer na abertura do capítulo intitulado conclusão, d'A virgem Guaraciaba: "Vede-a! com os cabelos soltos ao vento, o olhar incendido, o seio arquejante, corre Beatriz pelas sendas rudes, que através das florestas conduzem da cidade de São Paulo às margens do Tiete” (CHAGAS, AVG, [1866] s.d. p. 279, sublinhado nosso). Observem que, no instante em que Beatriz corre para o precipício, por meio desta mesma estratégia cinematográfica, o narrador convoca o leitor a olhar, como se estivesse movendolhe a cabeça. E, à proporção que vai narrando, conhecendo os segredos mais íntimos de suas personagens, confidencia ao leitor a intenção de morte de Beatriz.

Em mais outra situação, depois de um anacronismo em $O$ juramento da Duquesa, o leitor ao lado do narrador transita pelo espaço ficcional. ${ }^{124}$ Sendo a galope ou na velocidade do trem, como cúmplice, o leitor empírico vai visualizando os pormenores do ambiente, acabando por preencher todo o quadro no final do relato.

\footnotetext{
${ }^{124} \mathrm{Em}$ outras obras se pode encontrar o mesmo recurso com a mesma intencionalidade narrativa, de forma que acerca o leitor da conversa entre duas personagens. Dispomos, portanto, alguns deles: (AVG), p. 65; 235. (OJD), p. 22; 65; 90-91; 108; 149. (AJVR), p. 16.
} 
Foi longa a digressão, e forçoso é que nos tornemos ao ano de 1642 e que nos dirijamos ao Colégio de Santo Antão, onde deve representar-se a Real tragicomédia do descobrimento e conquista do Oriente pelo felicíssimo rei, décimo quarto de Portugal, D. Manuel, de gloriosa memória.

Entremos no pátio das escolas, onde se construíra um grande tablado, para o qual se dirigem de toda a parte, em liteiras, em cadeirinhas, em coches ou a cavalo os principais fidalgos da corte portuguesa. Quando entramos e que tomamos lugar modestamente no tablado que ficava sobre a porta das escolas e onde se dava entrada aos pais dos alunos o ensejo de poderem admirar as glórias de seus filhos, o teatro está já quase todo completamente cheio e do canto onde nos escondemos [o narrador e o leitor] podemos ver os brilhantes espectadores que guarnecem a sala.

Num trono forrado de brocado de ouro, com um rico docel e cortinas magníficas, está el-Rei D. João IV, um pouco sombrio, trocando apenas algumas breves palavras com a Rainha D. Luísa, cuja altiva presença infunde a todos veneração e respeito. [...] No momento em que entramos, D. Teodósio, obtida licença de seu pai e de sua mãe, passava para uma geral, que ficava próxima da tribuna como hoje diríamos, geral, toda colgada de seda da China de várias cores e onde a régia criança passeou por algum tempo sozinha e absorta num cismar precoce.

Do lado direito da tribuna régia havia uma outra adornada de cortinas de raso verde e colorido, com franjas de outro, sanefas de brocado e franjões de ouro e seda, alcatifada, além disso, de magníficos tapetes orientais. Do lado esquerdo do camarote do trono, ficava uma outra galeria em tudo semelhante à primeira. A da direita era destinada para os principais fidalgos da corte, a da esquerda para as damas de honor e outras senhoras ilustres da fidalguia portuguesa (CHAGAS, OJD, [1873] s.d, p. 42-43, grifo nosso).

O uso da primeira pessoa do plural abre espaço para que se entenda que o leitor está implicitamente incluído na ação narrativa, estando ele juntamente com o narrador na arquibancada do teatro, observando os adereços e as pessoas presentes. A maneira como descreve o cenário, pontuando a descrição com expressões adverbiais de lugar, “à direita” ou "à esquerda”, consegue transformar o relato como se fosse uma imagem produzida por uma câmera, que se move pelo olhar do narrador.

Já em outro capítulo, intitulado de Planos tenebrosos, em O juramento da Duquesa, inicia-se no calor do diálogo entre as personagens Juliana e D. João da Costa, bem aproximado ao texto teatral. E, certamente, se quiséssemos fazer um teste de encenação, pouco ou quase nada seria necessário para levá-lo ao tablado. Neste trecho, por exemplo, podem ser visualizadas orações relacionadas à linguagem fática, tais como: “Quem temos?”; “Que dizes?”; “Oh! Falai!, falai depressa”; “Bem sei! [...] mas continuai! Continuai!”.

Vale dizer que, mesmo diante da busca de uma reprodução fiel do espaço e das relações humanas tanto no plano político como no cultural, Pinheiro Chagas não se descuidava do 
humor romântico. ${ }^{125}$ No capítulo A Justiça do século XVII, por exemplo, a tensão do inquérito é quebrada e serve de crítica ao amadorismo com que se tratavam questões ligadas à liberdade e à sobrevivência do homem seiscentista. O episódio se refere ao fato de que um dos juízes, em vez de estar prestando atenção aos depoimentos dos acusados, aproveitava para fazer poesias para damas que conhecera na noite anterior. O mesmo ocorre na cena dos últimos momentos de vida do poeta D. Agostinho Manuel no cadafalso. Contudo, mesmo diante da morte inevitável, ele ironiza a capacidade humana de transformar barbáries em verdadeiros espetáculos. Não deixa ainda de realçar o ridículo da situação, dizendo que, como artista, ele deveria morrer com graça, para quem sabe ser lembrado pela História tanto pelos versos como por sua morte bem encenada.

- Bravo! Disse ele. Sou dos atores da tragédia dos que mais se podem gabar de chamar concorrência no teatro. Também a peça é a mais comovente do que um Auto sacramental de Lope de Vega, ou Comédia famosa de Calderón. E há damas na multidão! Bem! Trata-se de se morrer com graça, como um gladiador romano na arena. Mas a esses vibravam-se golpes artísticos, ao passo que este personagem mascarado é capaz de me cortar tão desgraciosamente a cabeça, que torne ridícula a minha morte.

Aproximou-se do cepo e disse para o algoz:

- Desconhecido amigo, penso que hás de representar um papel na história da minha morte, se algum dos meus confrades em Apolo a julgar digna de algumas décimas fúnebres. Vê como manejas esse cutelo. Disseram-me que é o mesmo que em Madri decepou a cabeça de D. Rodrigo Calderón. Com isso muito folgo, porque nesse caso já teve a honra de ser cantado por D. Luís de Gôngora. Eu te recito a décima... não te impacientes amigo... e seja esta a minha última citação... [...] Ora, vejamos, pois, o que essa língua dirá de mim... Cá estou, amigo... Que Deus se amerceie da minha alma e que os séculos futuros se lembrem tanto dos meus versos, como dos do imortal Gôngora. É este o meu desejo. Apenas ele acabara de proferir essas palavras, brilhou no ar o cutelo do algoz e momentos depois a cabeça de D. Agostinho Manuel era também separada do tronco (CHAGAS, AMV, [1873] s.d, p. 197).

Neste sentido, os dois episódios não deixam de ser grotescos, pois subvertem a lógica da realidade. Conforme Moisés, o grotesco "funda-se na surpresa, no imprevisto, no insólito, traduz a angústia não perante a morte, mas perante a vida, que gera a destruição de toda

\footnotetext{
${ }^{125}$ Algumas destas cenas podem ser localizadas e apreciadas pelo leitor curioso: 1) O episódio do padre Manuel de Paiva, que estava sendo leiloado na feira livre. Apesar de Pinheiro Chagas ter extraído este acontecimento da crônica de Simão de Vasconcelos, ele pincela com algum humor a cena. (AVG), p. 100-102; 2) Braz Mattoso protagoniza pelo menos três cenas engraçadas. Numa delas, o bonachão se veste de padre para salvar a pele do amigo Luiz e tem que cantar para o rei em Odivelas, o que faz desafinadamente. No outro dia, o verdadeiro frade fica em situação constrangedora, por não se lembrar de que cantara na noite anterior. (ACDJV), cap. XV; 3) As aventuras envolvendo o Benito Picon. (GM), cap. XI. Estas duas últimas personagens citadas são comparadas a Sancho Pança, pelas aventuras que passam com seus amos e pelo ceticismo, que beira o cômico.
} 
ordem [...]” (MOISÉS, 2004, p.214-215). Em ambos os casos, parece absurdo que, diante de uma morte certa e violenta, D. Agostinho se preocupasse em morrer com graça e o juiz se mantivesse alheio ao curso do julgamento que decidia a vida de um homem.

Como vimos, é inegável a interferência dramática na composição dos romances históricos de Pinheiro Chagas, principalmente em A máscara vermelha e O juramento da Duquesa, o que nos confirma uma de suas premissas, a de que sua criação ficcional é “[...] onde o leitor julga ver as cenas sucederem-se umas às outras, como se desenrolassem no tablado de um verdadeiro teatro” (CHAGAS, NEC, [1867] 1890, p. 40). 


\subsubsection{Os atores da tragicomédia da Restauração}

Em O labirinto da saudade, Eduardo Lourenço (1992) considera que, devido aos três traumas nacionais - a fundação pelo matricídio; o período de União Ibérica e o Ultimatum inglês -, foi se instituindo no imaginário do povo português um complexo de abandono. E que a ideia de nação desde a sua origem sempre foi um engodo, pois “[...] mesmo na hora solar da nossa afirmação histórica, essa grandeza era, concretamente, uma ficção” (LOURENÇO, 1992, p. 19, grifo nosso e do autor, respectivamente). Nessas bases, segundo podemos concluir, Portugal nunca conseguiu ascender a uma fase de maturação, já que, em vez de se confrontar realisticamente com os seus problemas, confiava sempre em profecias sobre o retorno de um herói que pudesse salvar a pátria.

Nesses sessenta anos [do império filipino] o nosso ser profundo mudou de
sinal. Como portugueses esperamos o milagre, no sentido mais realista da
palavra, aquilo que, razoavelmente, não podia ser obtido por força humana
[...] que representou, ao mesmo tempo, o máximo de existência irrealista
que nos foi dado viver; e o máximo de coincidência com o nosso ser
profundo, pois esse sebastianismo representa a consciência deliberada de
uma fraqueza nacional, de uma carência, e essa carência é real (IDEM, p.
22, grifo do autor).

Iniciada a Dinastia de Bragança, depois de sessenta anos sob o poder da coroa espanhola, muitos consideravam a “ [...] aclamação de D. João IV [como] a verdadeira vinda de D. Sebastião” (MARTINS, [1881] 1951, p.119). Contudo, o que se viu foi um período joanino anárquico, sangrento, com várias intrigas políticas instauradas na corte, que poderiam ter sido evitadas se não houvesse sido incentivadas pela omissão do monarca, sendo a morte de Francisco de Lucena uma prova disso.

- Assim é, senhora duquesa, respondeu D. João da Costa. Sabeis como D. João IV é retraído e falto de resolução. Não deu um passo para salvar Francisco de Lucena, não deu um passo para o condenar. Os juízes deixados a si mesmos, hesitaram. O fato de ter o ministro correspondência com a corte de Madri, mesmo para objeto lícito, bastava para levar os juízes a formularem uma sentença condenatória; mas Francisco de Lucena alega que el-rei tinha conhecimento dessa correspondência, que lha permitira sempre, que sabia qual era o objeto que tratara. E el-rei não desmente estas asseverações. Em presença disto, os juízes hesitam, e estão decididos a pronunciar uma sentença de livramento (CHAGAS, OJD [1873] s.d, p. 74). 
Mas a desordem estava instituída em todos os segmentos nacionais

Por isso também, tanto no tempo dos Filipes como depois da proclamação da independência portuguesa, os habitantes de Lisboa só contavam consigo mesmos, para se defenderem das agressões dos salteadores que, animados pela impunidade, infamavam a cada instante as ruas da capital com roubos ou assassínios, ou das vinganças particulares, que também se satisfaziam às soltas. O que sucedia em Lisboa reproduzia-se nas províncias, mas como era natural, ainda muito mais agravado. Na província não havia só brigas, havia verdadeiras guerras particulares, como na Idade Média, como no tempo em que as discussões tradicionais de famílias inimigas ensangüentavam os campos e as cidades (CHAGAS, AMV, [1873] s.d, p. 69).

Mesmo sob os ares de um período que inspirava tanto progresso e ideais liberais, por que Portugal parecia não se reerguer em meio às ruínas? Para se entender os verdadeiros interesses por trás da Restauração é preciso, segundo Luís Reis Torgal (1981), conhecer o caráter sociológico de 1 de Dezembro de 1640. Para este autor, a organização e o desfecho da revolta se deram graças à nobreza, ao clero e a alguns letrados, muitos dos quais já tinham estreitas relações com a Casa de Bragança. Ele explica ainda que o povo não aderiu inicialmente ao movimento, mesmo tendo sofrido influência dos jesuítas, devido às pressões de uma parte da classe letrada e de nobres ligados ao governo filipino. No entanto, mesmo que tardiamente, a população assumiu um importante papel na intensificação e ampliação da rebelião.

Um círculo aristocrático vinha, na verdade engrossando em volta do Duque desde há bastante tempo, dando-lhe consistência da sua responsabilidade, da sua grandeza e ajudando-o a ultrapassar as suas hesitações. È verdade que o povo aderiu ao movimento e terá sido mesmo ele que de alguma forma, orientado sobretudo pelos jesuítas - que mantinham ainda, como outras ordens religiosas, certas ligações com a classe popular - , terá dinamizado a revolta antes de 1640 e que assim terá impulsionado à distância o movimento de 1 de Dezembro. [...] Por isso o povo foi, na realidade, em 1649, apenas uma espécie de pelotão de limpeza, que atuou só depois do movimento eclodir. A sua hesitação e os eu receio justificavam-se plenamente (TORGAL, 1981, p. 79-82).

Tese idêntica defende Oliveira Martins ([1881] 1951), um século antes em sua História de Portugal, de que o movimento não teria sido uma revolução, mas sim uma conjuração, já que o povo esteve afastado das decisões políticas. Para ele, a conspiração foi impulsionada pelo desejo da nobreza que se via prejudicada pelo governo filipino. Embora Pinheiro Chagas 
julgue também que a Restauração surgiu da vontade aristocrática, em sua opinião, a sua realização só se tornou possível com o movimento popular.

Ainda que Pinheiro Chagas e Oliveira Martins divirjam sobre o caráter decisivo da ação popular na Restauração, os dois concordavam que este movimento foi somente uma troca de atores, em que o pusilânime e inapto rei D. João IV continuava a obra de dissolução do país. Na concepção martiniana, esse episódio histórico teria sido “ [...] uma mutação de cena, uma substituição de pessoas, um acontecimento imprevisto e singular” (MARTINS, [1881] 1951, p.140). Com igual interpretação, tempos antes, em O juramento da Duquesa (1873), este assunto vem à tona sob a forma de alegoria no momento em que os jesuítas apresentam a mesma tragicomédia do tempo de Filipe III para o rei português e sua corte, só substituindo um nome por outro. Isso parece sugerir-nos que entre o governo de D. João IV e o do seu antecessor espanhol não havia muita diferença.

\footnotetext{
Sai dos seus Filipe

E para os seus vem

Louvai, portugueses, Não percais tal bem.

Por que cá vos fique

Fama imortal,

Deixai-nos Filipe

Rei de Portugal.
}

Os jesuítas nem se haviam dado ao trabalho de escrever outras quadras. Tinham conservado o clichê, fazendo-lhe apenas ligeiríssimas modificações, mas transformando coplas filipinas em hino bragantino.

De Bragança o duque

Reinar aqui vem.

Louvai, portugueses,

não percais tal bem.

Por que cá vos fique

Fama imortal,

Aceitai a coroa

rei de Portugal

$[\ldots]$

Mas voltando aos sucessos da representação da tragicomédia, tornamos a dizer que ninguém atendia ao que se passava em cena, e que as emendas dos jesuítas passaram sem reparo (CHAGAS, OJD, [1873] s.d, p.61-62, grifo do autor).

Este capítulo, intitulado A tragicomédia dos jesuítas, procura destacar que o governo de D. João IV mantinha ainda uma sólida relação com os jesuítas, mesmo sabendo que os 
princípios da Companhia de Jesus eram: “ Obedecer, [...] sempre; ainda quando, por motivo de fragilidade humana, a ordem possa ser errada” (MARTINS, [1881] 1951, p.99). Esta ideia de um rei instrumento da ordem jesuíta é ratificada pela sentença que ele dirige a cada integrante da conjuração, resguardando os prestígios sociais dos supostos traidores até mesmo na hora da morte. Assim, aqueles ligados à classe popular, além de condenados à morte, morreram pelos métodos mais cruéis. Os nobres foram sentenciados à decapitação e o clero punido apenas com prisão perpétua que, tempos depois, foi relaxada pelo indulto régio.

Com esse cenário nada promissor, o período da Restauração que anunciava o retorno da liberdade ao país, na prática, transformara-se numa época de extrema intolerância e injustiças sob o falso pretexto de manter a reconquistada independência. De fato cada segmento nobreza, clero e o próprio rei - buscava proteger seus próprios interesses. Por isso, conspirar e sentenciar à morte passou a ser um ato corriqueiro em Portugal. E essas execuções eram transformadas em verdadeiros espetáculos teatrais.

Então o algoz mascarado tomou nas mãos as quatro cabeças gotejantes de sangue e mostrou-as ao povo. Respondeu-lhe uma exclamação unânime. A justiça dos homens estava satisfeita. Esquecendo os pormenores dilacerantes da tragédia que acabava de representar-se a multidão acabava de jurar pelo sangue derramado naquele cadafalso, que saberia manter contra todos os inimigos, externos ou internos, a reconquistada independência. A realeza de D. João IV acabava de ter o batismo de sangue. Era indispensável, segundo as ideias do tempo. A história preferiria contudo que essa realeza nacional, em vez de afirmar pela severidade implacável, e até mesmo pela iniqüidade, tivesse o batismo de sangue não nos cadafalsos, mas só no campo das batalhas e que D. João IV preferisse afirmar as prerrogativas da sua coroa com o direito de perdoar, em vez de afirma-las com o direito de punir (CHAGAS, AMV, [1873] s.d, p. 198).

Como se pode ver pelo trecho destacado, D. João IV, como o primeiro rei da Casa de Bragança, não abre a linhagem de forma grandiosa. Pelo contrário, ele figura como um monarca intolerante e injusto, que transforma Portugal numa terra de traidores. “- Se D. João IV quisesse auxiliar a causa de Filipe IV não podia andar de outro modo. Com estas punições injustas é que se criam os verdadeiros traidores [fala de D. Francisco Manuel de Melo]” (CHAGAS, OJD, [1873] s.d, p.62).

Além dessas censuras, o capítulo clemência régia, visivelmente construído num tom crítico e irônico, veicula outras imagens depreciativas deste monarca. A primeira delas é a de um homem impiedoso e egoísta, preocupado apenas em se manter no trono, e com sua imagem no estrangeiro de ser um rei severo com aqueles que o traem. 
[...] O rei conservava-se impassível.

- Senhora, disse ele amaciando tanto quanto pode a sua voz áspera e cortante, senhora, confesso-vos que folgaria de poder aceder às vossas súplicas. Mas há deveres sérios a que sou forçado a obedecer. Se eu perdoasse, amanhã dir-se-ia em Madri que o Duque de Bragança não se sente seguro no seu trono, e que teme arrostar as iras dos fidalgos! Diriam que o Duque de Bragança não sabe nem ousa ser rei, porque não tem coragem para punir os rebeldes. [...]

Se a clemência é um dever, terei portanto de perdoar a todos; não! Assim o quiseram, assim o tenham! Se eles vencessem, Filipe IV não me perdoaria e a minha cabeça rolaria no cadafalso, onde rolou a cabeça do meu antepassado o Duque D. Fernando de Bragança! Venci eu. Uso da vitória! (CHAGAS, AMV, [1873] s.d, p. 171).

Diferente da altiva figura de D. João IV, Portugal cada vez mais se transformava numa terra sem exército, sem lei, sem dinheiro, governada pelas mãos de um apático rei e pela fria e calculista ordem dos jesuítas.

Mas a degeneração da Casa Bragantina não termina com D. João IV, intensifica-se ao longo da dinastia. E um outro monarca que é alvo de especial ataque devido ao seu hábito lascivo e perdulário é D. João V. Em A corte de D. João $V^{126}$ (1867), o rei é desenhado de maneira caricaturesca e a sua devoção à Igreja só perdia para a adoração às mulheres, incluindo as freiras. É considerado com vaidosa magnificência, pois tinha a mania de parodiar Luís XIV. A tese defendida pelo autor na diegese é a de que ele teria sido grande “[...] se o não tivessem estragado totalmente com uma educação fradesca e freirática” (CHAGAS, ACJV, [1867] 2002, p. 88). Num desses episódios cômicos, D. João V censura as medidas de Camões do Rossio por ter prendido os jesuítas, sob a dissimulada alegação de eles não serem padres. Veementemente, D. João V exige a soltura imediata deles. Contudo, Caetano SoutoMayor, não querendo sair repreendido da audiência e nem deixar que os padres fossem libertados tão logo do cárcere, cita o nome da Condessa de San Pablo. Foi o suficiente para que o rei se esquecesse do real motivo que o levara a chamar o seu corregedor. Este, exímio conhecedor das distrações do rei, sabendo que ele gostava de mulheres mais do que de missas, reverte o argumento ao seu favor e sai da sessão sendo parabenizado, provocando completo burburinho entre os presentes, pois esperavam uma humilhação pública.

\footnotetext{
${ }^{126}$ Romance ao estilo de capa e espada, em que o foco é a corte de D. João V, como o título bem alude. Assim, à medida que se vai desenhando a vida na corte de D. João V, desenvolve-se a rivalidade entre o pajem D. Luiz de Mello e el Rei D. João pelos amores da condessa de San Pablo. Durante a narrativa, vão ocorrendo vários problemas envolvendo duas forças contrárias ligadas ao rei: de um lado, Caetano Souto-Mayor, e de outro os Jesuítas, cada qual tencionando angariar proveitos para a sua ordem.
} 
Por isso a meio do caminho parou.

- Meu senhor, disse ele com que hesitando, permite-me Vossa Majestade que lhe dê informações acerca de uma pessoa, a quem Vossa Majestade fez outrora a honra de prestar alguma atenção?

- Quem é essa pessoa? Tornou o rei curioso.

- A condessa de San Pablo, meu senhor.

- A condessa! Falaste-lhe, Caetano Souto-Mayor?

Um relâmpago de orgulhoso júbilo passou rapidamente nos olhos do Camões do Rossio.

- Não, meu senhor. Mas eu estou abusando dos instantes preciosos de Vossa Majestade. Anseio por me ir lançar aos pés dos padres jesuítas, a quem por involuntária irreverência...

- Deixa lá os padres! Que esperem!

- Lembre-se Vossa Majestade, continuou ingenuamente o Camões, que a salvação da minha alma...

- Ímpio!

- Não, meu senhor! Foi o porteiro...

- Bem sei, bem sei, tornou o monarca rindo agora às bandeiras despregadas, a peça foi um pouco pesada; mas enfim o que sucede à condessa? ...

- Meu senhor, sabendo que ela vive muito retirada, pensei que lhe seria aprazível, e útil ao mesmo tempo à salvação da sua alma, residir algum tempo num convento. Amanhã há abadessado em Odivelas e outeiro por conseguinte. Indo a condessa passar lá alguns dias, goza a um tempo as inocentes distrações das esposas do Senhor, e recreia o seu espírito com tão devota convivência.Tomei então a liberdade de aconselhar às monjas de Odivelas que lhe dirigissem um convite. O convite foi feito, a condessa aceitou e pediu e obteve a necessária licença de sua majestade a rainha.

- Vai então a condessa para Odivelas? Tornou D. João V, com os olhos chamejantes, e abaixando pensativo a cabeça.

- Sim, meu senhor, tornou com indiferença o Camões do Rossio. A cela que lhe destinam é a última do dormitório, a que fica próxima...

- Da passagem secreta? Murmurou D. João V.

[...]

Dirigiu-se à porta. El rei deu-lhe o braço e acompanhou-o.

Quando a porta se abriu, e que o grupo dos dois apareceu diante dos olhos dos cortesãos, só o respeito da etiqueta pode reprimir o murmúrio de espanto que se ia começando a levantar.

Os três jesuítas, que se pavoneavam no meio dos grupos, fizeram-se fulos.

[...]

E fechou a porta dizendo:

- Meus senhores, por hoje está a audiência finda (CHAGAS, ACDJ, [1867] 2002, p. 96-97).

Camões do Rossio é o retrato de uma fidalguia que bajula, trama, dissimula, representando o papel mais conveniente para obter as facilidades régias. Nesse caso, ele vai, de certa forma, agenciar a condessa, pois ele sabia que a maneira mais rápida e fácil de influenciar o poder do soberano seria pelas confidências da amante. Semelhante situação atravessa outra personagem, a Tereza de O terremoto de Lisboa, pois, como indicamos, Carlos a convence de ser concubina de D. José, a mando do Marquês de Pombal. 
Nessa medida, uma das críticas veladas na representação da nobreza é o fato de maridos ou amantes agenciarem suas mulheres para que pudessem se aproximar do poder. Como em um jogo de xadrez, a dama torna-se fundamental para o xeque-mate. Aqui também não é diferente, pois por intermédio dela o estrategista se acerca do rei, conquistando indiretamente todos os benefícios, só por serem íntimos.

Quase sempre as representações dos nobres relacionam-se com um poderio falido, que cheira a mofo, sustentado apenas pela ilusão do título. Um desses tipos caricatos é Gil Coelho, de $O$ terremoto de Lisboa, alusão a outro, Gil Cogominho, de O fidalgo aprendiz, de D. Francisco Manuel de Melo. O primeiro deles deixa os negócios para se dedicar às pretensões fidalgas, isto é, tornar-se um homem da corte. Coelho não se contenta em ser marido de D. Mafalda Rita, pois ele quer ter a sua própria nobreza. Por isso, além de vasculhar toda a sua ascendência inúmeras vezes, procurava acompanhar a moda e falava nem que fossem dois dedos de francês.

- Os tempos vão maus para a gente nobre, dizia o honrado tendeiro que fora fornecedor da casa de D. Maria de Jesus [mãe de Luiz Correia]. [...] Ora veja o Sr. Luiz Correia, enquanto eu me esquecia da minha nobreza, e tratava de ganhar a vida como qualquer mecânico, trazia sempre a bolsa bem fornecida. Quando pretendi honrar os meus ilustres ascendentes e viver à lei da nobreza, parece que fugiu de mim a fortuna. Ó manes de Pero Coelho [um dos executores de Inês de Castro]!

- É singular, observou Luiz Correia sorrindo; quando o meu amigo nos fazia a fineza de nos mandar para casa o açúcar e a manteiga, nunca nos constou que tivéssemos a honra de ser fregueses do descendente de um homem a quem fora o coração arrancado pelas costas.

- É verdade! É verdade! Pois isso também descobriu-se depois, tornou Gil Coelho um tanto embaraçado. Revolvendo uns papéis velhos lá de casa, vim a saber que Pero Coelho tivera um filho em Espanha, o qual casou uma açafata de Isabel a Católica...

$[\ldots]$

- [...] Pois, meu caro amigo e Sr. Gil Coelho, uma coisa tem de notável a sua família é que em quatro passadas atravessa a história toda.

E Luiz Correia, que não podia já conter uma forte vontade de rir, afastou-se de Gil Coelho para ir apertar a mão ao seu parente e amigo o poeta [Correia Garção] que havia depois de contar numa comédia, que não tem, aliás grande merecimento, estes ridículos das assembleias.

[...]

-Dispense-me por enquanto, e, se faltar parceiro, cá estou ao seu dispor, tornou Garção.

- Bem! Bem! Não quero violentar pessoa alguma. Ao sr. Luiz Correia não ofereço carta, porque esse já eu sei que não joga nada! Aqui não há etiquetas. Allons, allons, conversem e viva a joia! (CHAGAS, OTL, 1874, p. 71-73). 
Embora D. Gil Cogominho, de O fidalgo aprendiz, não seja vil como Pedro Bonete que tenta ascender socialmente pelos modos mais escusos, ele também é uma farsa, pois aspira a viver conforme o ideal cavalheiresco. A comicidade da peça de D. Francisco está no fato de ele ser um burguês bronco que almeja ser um homem da corte, de maneira que só lhe resta obter os dons necessários para seu ingresso: cantar, dançar, esgrimir e fazer poemas. No entanto, D. Gil não passa de um pobre coitado, que ostenta uma riqueza que não existe e, ainda, imaginase cercado de considerações devido a isso. Mas o que ocorre, na verdade, é que todos o ridicularizam e enganam, até mesmo o seu único criado. A entrevista com Brites, reproduzida em O juramento da Duquesa, é uma prova de como ele não consegue convencer o outro de sua nobreza, muito menos quando tentava apresentar uma das habilidades do cavalheiro ideal, que não aprende porque se impacientava com os mestres. Em seu estudo sobre $O$ fidalgo aprendiz, Antonio Corrêa de Oliveira observa que:

As ambições de D. Gil correspondem no fundo a uma tendência natural e louvável - a elevação pessoal, de acordo com as ideias do tempo. Mas o escudeiro provinciano perdera a flexibilidade que a vida exige de nós para uma constante adaptação à realidade e que seria indispensável para a consecução dos fins a que se propunha. Move-se como puro mecanismo, sem vida, no rígido automatismo dos seus interesses. E tudo o que intenta é nos colocar perante uma expectativa e surge subitamente ineficaz e frustrado (OLIVEIRA, s.d, p. 20).

É certo que o cômico da peça se mantém durante todo o desenrolar da história, exceto no desfecho da trama, em que a personagem toma consciência de sua realidade limitada, surgindo, daí, o trágico. Sua mania ilusória de querer o mundo segundo os seus ideais parece aproximar-se da personagem de outro clássico, D. Quixote.

O retrato que Pinheiro Chagas constrói da nobreza do período seiscentista é o de uma casa aristocrática em ruínas, cheias de bajulações e ociosidade, gente sem condição moral ou financeira para estar influenciando o poder real. D. João da Costa, conselheiro de guerra de D. João IV, encaixa-se nesse protótipo aristocrático que faz intrigas, calcula todos os atos e estabelece alianças para conquistar posições e prestígios. Depois da morte injusta do Duque, e o ódio que a Duquesa nutria por Francisco de Lucena, ele vê surgir a oportunidade de destituir do cargo de ministro o seu adversário. Para isso, forja documentos e testemunhas para incriminar Lucena, sob alegações de sua falta de habilidade em assuntos de defesa nacional. 
- Desejo fazê-lo sair do poder, por que a sua influência nos conselhos delrei é essencialmente nefasta, porque enquanto ele for ministro, não pode haver exército capaz, não pode haver boa direção nos negócios militares (CHAGAS, OJD, [1873] s.d, p.96).

Seja qual for o motivo que se esconde por trás das investidas ardilosas de D. João Costa, nesse drama, parece que poucos assumem suas reais intenções no projeto de vingança. $\mathrm{O}$ sentido do trágico e do cômico pode também estar presente nessas situações de revanche, em que há a alternância das máscaras de vencedor e de vencido. Se na primeira parte do drama, o leitor testemunha Francisco de Lucena ressentido e impassível ordenar a prisão dos inimigos da Casa de Vila Real sob a acusação de conspiração contra D. João IV, ironicamente, tempos depois, vê o mesmo delito recaindo sobre Lucena, que tem a mesma morte que os seus desafetos.

Juliana é outra demonstração da personagem vingativa bem aos moldes do bandido romântico, que se orienta pelos princípios que estabelece. O infortúnio transformou esta mulher boa num ser impiedoso, cuja primeira reação foi destruir aqueles que lhe tiraram o objeto amado. Diferentemente das outras mulheres, que se deixam agenciar pelo masculino, ${ }^{127}$ a Duquesa de Caminha tem artimanhas e desejo suficientes para se mover sozinha. Consumida pelo ódio, faz uso dos seus atrativos de mulher, mesmo contra a vontade, para ludibriar os seus adversários.

O seu traje de viuvez é outro detalhe interessante para percebermos a transgressão dessa personagem $^{128}$. Isto porque, antes do século XVIII, as mulheres viúvas deveriam permanecer em estado de clausura, de forma a impedi-las de manter uma vida social dentro da normalidade $^{129}$. Condição que não assume Juliana durante o luto do marido, pois ela estabelece contatos, recebe os aliados em casa, quebrando convenções, não hesitando em cumprir a promessa de punir os responsáveis pela morte do Duque. Há, portanto, durante a intriga, uma diluição da imagem da mulher angelical, dando lugar a um feminino frio, irônico e perverso.

\footnotetext{
${ }^{127}$ Apesar de ter sido ideia de D. João Costa para o envio da carta indiretamente a Pedro Bonete. O conteúdo da missiva é criado por ela e não ditado pelo cúmplice.

${ }^{128}$ A Duquesa de Caminha tinha muito da Marquesa de Alorna. Apesar das dificuldades econômicas que a viuvez acarreta a esta, a sua residência transforma-se num foco de ebulição cultural, onde se debatem as novas ideias políticas e também as novas correntes estéticas e literárias. Bocage e Alexandre Herculano, em períodos diferentes, são dois dos frequentadores do seu salão.

${ }^{129}$ Cf. Lopes, 1989, p.135-137. Esta autora discute a mudança de paradigma quanto a viuvez feminina a partir da segunda metade do século XVIII. Desde então, as viúvas começaram a sair e a se divertir.
} 
A duquesa estava realmente majestosa e trágica. [...]

- Calai-vos, que eu sei tudo! Bradou ela. Sei tudo, entendeis? Há um ano que guardo este segredo no fundo da minha alma! Há um ano que por baixo das minhas vestes de viúva palpita o meu coração só com o desejo de vingança! O sopro ardente desse fatal anelo murchou todos os sentimentos bons que outrora se escondiam no peito. Honra, brio, pundonor, lealdade, misericórdia, tudo em mim está subordinado a este pensamento único vingar meu marido... e vingá-lo não só do ministro que tramou a sua morte, não só do rei que assinou a sentença, mas também, mas principalmente do espião infame que o denunciou, do carrasco voluntário que subiu ao cadafalso para lhe decepar a cabeça... E esse carrasco sois vós! A vingança está conseguida, bem o vedes, continuou ela com um riso sarcástico. Foi com as vossas próprias mãos que assegurastes o sucesso da minha vingança. Tive de representar para isso uma comédia infame? Bem sei! Que importa! Se nesta sociedade se premiam os denunciantes e se permite a um assassino assumir as funções de executor das sentenças da justiça; se aqui se recompensa a infâmia e se anima o crime, se é necessário para serem punidos os celerados lançar-se mão das armas ilegítimas, de quem é a culpa? É minha ou é deles? Era criminoso meu marido? Não! E mataste-lo, contudo. Os criminosos sereis vós, e esse crime não atraiu sobre a vossa cabeça senão as recompensas e os prêmios. Pois bem! Eu não tive remédio senão levantar do chão o mesmo traiçoeiro punhal com que tínheis dilacerado a minha ventura e trucidar-vos com ele! Consegui-o enfim!

- E a vossa promessa! E o juramento feito por D. João da Costa! Pelo vosso amante, respeitável viúva! [Fala de Pedro Bonete].

-Insultai-me!Insultai-me à vontade! Respondeu com uma gargalhada sinistra a Duquesa de Caminha! Tudo se permite aos moribundos! D. João da Costa, o meu amante como vós dizeis - e o riso desprezador da duquesa era capaz de gelar de terror quem a ouvisse -, D. João da Costa, nada sabe, D. João da Costa quis cumprir lealmente o que prometera, e eu fingi aceder, encarreguei-me até de emprestar os meus criados para a vossa evasão, eles lá foram ao cárcere e eles para lá vos conduzirão de novo, infame, víbora, depois de eu vos ter quebrado os dentes e arrancado o veneno.

- Enganai-vos! Exclamou D. Pedro Bonete, com os dentes cerrados e os olhos chamejantes, não sabeis ainda com quem lutais.

$\mathrm{E}$ dando um salto de tigre, quis arrojar-se às goelas da duquesa. Recuou logo, porém, soltando um grito de dor. Na mão da duquesa lampejara um pequeno punhal e o braço de D. Pedro descaíra amortecido, varado pela aguda lâmina (CHAGAS, OJD, [1873] s.d, p. 178-79).

A primeira transformação de sua personalidade é o endurecimento. A perda da fragilidade feminina é tão evidente que, no segundo momento do drama, quase não aparece o nome da personagem, que é sempre referida pelo codinome de seu título de Duquesa de Caminha. Este parece ser um indício lógico de que ela vai, passo a passo, assumindo a identidade do marido, ou seja, torna-se cada vez mais viril, à medida que os inimigos vão caindo, um a um. 
Ah! Fosse eu homem, que não confiaria destes caminhos tortuosos a minha vingança! Fosse eu homem que iria face a face, de rosto descoberto, cravar no coração do infame o punhal, que nunca podia causar-lhe tantas dores, como as que ele me infligiu com a sua inflexível crueldade (CHAGAS, $O J D$, [1873] s.d, p. 74).

Diante disso, podemos concluir que a personalidade de Juliana, agora mais cética e taciturna, foi moldada pelo seu espírito vingativo e por uma culpa que parece não sentir. Mas, depois de consumada a vingança, nada mais interessa a Juliana neste mundo, pois a missão terminara. Na verdade, ela tinha plena consciência de que uma vez lançada no caminho do crime, não havia retrocesso; obtida a revanche, a vida deixara de ter sentido, restando apenas o espírito irrequieto. Assim, no auge do desespero, considerando a vingança como um dever sagrado, procura então a legitimação de seu ato nas palavras sacras de Pe. Vieira.

Mas até mesmo Pe. Vieira, a figura jesuítica de proa da Restauração, aparece fazendo maquinações contra Lucena. Em todo conjunto de sua obra, Pinheiro Chagas recupera dois Vieiras em fases distintas, um tímido e emocionado em A conspiração de Pernambuco ${ }^{130}$, e outro eloquente e enérgico no período áureo ${ }^{131}$ em $O$ juramento da Duquesa ${ }^{132}$. Nas duas aparições, embora ele tenha um histórico de interventor, esta personagem não consegue dissuadir Rodrigo e muito menos a duquesa de seus planos de vingança, o que nos confirma a

\footnotetext{
${ }^{130}$ Nos cinco últimos capítulos deste livro, apresenta-se a trama centrada numa intriga e caracterização de personagens românticos, que transitam em espaços históricos. A narrativa nos mostra um amor contrariado por razões religiosas entre Rodrigo e Margarida. O capitão baiano, ao conhecer a jovem holandesa, sente o seu patriotismo e a sua religiosidade esfriarem. O pai de Margarida, inicialmente, opõe-se ao casamento da filha com Rodrigo e exige a sua conversão. Os dois se casam, mas, ainda nas núpcias, Margarida fica viúva.

${ }^{131}$ Imagem aproximada de Vieira já na fase de maturidade pregando o Sermão de Santo Antônio. Uma cena muito parecida também se pode encontrar em $O$ juramento da Duquesa, quando Pe. Vieira investe com os mesmos argumentos de tolerância e benevolência na tentativa de impedir que a Duquesa de Caminha vingasse a morte injusta do marido.

${ }^{132}$ Neste romance há a dramatização do Sermão de Santo Antônio, pronunciado na Igreja das Chagas, em Lisboa, em 14.09.1642. Este texto trata acerca dos projetos públicos e da desigualdade dos impostos. Em seu discurso, o pregador tinha que convencer as três camadas sociais (o povo, o clero e a nobreza) do pagamento de tributos para manter o exército português na defesa da independência recém-conquistada. Mereceria referência, agora, o fato de que o autor, após a teatralização da pregação do Sermão de Santo Antônio, nomeou o capítulo seguinte de Tragicomédia dos jesuítas. Numa linha comparatista, o narrador ressalta o poder inventivo de Pe. Vieira, que transformava um texto bíblico em sermão, ao contrário dos outros jesuítas, que, pelo seu espírito convencional, não conseguiam ao menos representar uma tragicomédia. Estavam distanciados de tudo, razão pela qual o título funciona como uma grande metáfora, pois, para Chagas, os jesuítas tinham uma limitação intelectual e eram bajuladores e oportunistas, sempre adequando-se ao novo governo que se estabelecia. Como exemplo, a peça dedicada a D. João IV, com algumas mudanças, fora no antigo governo oferecida ao rei da Espanha, Felipe III, quando do domínio espanhol.
} 
ideia de que, antes de ser um sacerdote que resguarda os preceitos cristãos, Pe. Vieira se mostrava orientado por interesses de estadista:

[...] discursarei no meu sermão acerca dos negócios públicos. Pregarei a conciliação, aconselharei o pagamento dos tributos. Aproveite quem aproveitar; quem lucra definitivamente é a pátria. [...] Não desviarei do meu intento [...].

- Prudência, Sr. Francisco Manuel! Prudência! [referindo ao modo que D. Francisco acusa os jesuítas de perderem Portugal] As épocas de revoluções são épocas sempre suspeitosas. Quando um regime qualquer está frouxamente estabelecido, em todos vê traidores. [Neste ponto da discussão, Pe. Vieira parece ameaçar D. Francisco por suas colocações] Francisco de Lucena pode não ser um criminoso que dizem, mas é inconveniente na secretaria do Estado, porque é impopular, porque é inábil, porque é orgulhoso. O que importa à causa nacional é que seja derrubado esse nefasto ministro. Importam pouco os meios (CHAGAS, OJD, [1873] s.d, p. 28-63).

Apesar de o narrador ressaltar uma imagem positiva de Pe. Vieira como patriota, por outro lado, deixa tácito que ele não estava excluído das máximas maquiavélicas da ordem, onde os fins justificam os meios. O referido trecho nos leva a pensar na seguinte questão: se Pe. Vieira, com seus sermões, convencia uma multidão a aderir às causas nacionais, por que não conseguiu demover dois fiéis de suas vinganças? Porque as ações inimigas que insurgiam contra os líderes Nassau e Lucena pareciam favoráveis aos seus propósitos políticos. Assim, Pe.Vieira poderia estrategicamente se colocar na posição de espectador, aguardando apenas a queda dos dois estadistas, mesmo que a morosidade do desenlace representasse um prejuízo inicial aos interesses da ordem.

É interessante ressaltar, por fim, que a maneira como aparecem na ficção os nomes mais importantes do jesuitismo português (Pe. Anchieta, em A virgem Guaraciaba, e Pe. Vieira, em A conspiração de Pernambuco e $O$ juramento da Duquesa) parece promover a desmistificação do seu vulto histórico. Isso se levarmos em conta que as ações de ambos não coadunam com a de um representante de Cristo, já que eles são movidos pelos interesses próprios, em nome da ordem ou da nação, permanecendo inertes, mesmo sabendo dos movimentos de traição, dos conluios, dos agenciamentos e dos atos de vingança que existiam. Logo, pela trajetória imposta a ambos, Pinheiro Chagas, embora exaltasse a genialidade dos dois jesuítas em matéria patriótica e literária, salvo os gongorismos vieirianos, rebaixa-os à condição humana, destituindo-lhes do caráter de santos. 
Essa maneira em dessacralizar a imagem dos vultos históricos pode ser encarada como uma tentativa de Chagas em mostrar a vida do passado o mais real possível aos olhos do leitor distanciado. Além dessa característica, ele também faz uso do emprego dos elementos cênicos, que ajudam na plasticidade e no movimento da narrativa, como podemos constatar.

Mas o interesse de leitura de A máscara vermelha e $O$ juramento da Duquesa não subsiste apenas no estilo de seu autor. A maneira como aproxima o período da Restauração, que deveria ser uma fase de evolução para o país, a uma tragicomédia, chama a atenção de quem lê os dois livros.

O leitor, que se sentir tentado a ler estas páginas, vai encontrar, além das peripécias romanescas e amores contrariados, o retrato de um Portugal decadente, dirigido por um monarca inepto, injusto e impassível. Vícios estes que podem ser imputados a sua corte, uma vez que “ [...] um fraco rei fazia fraca forte gente [...]” (CHAGAS, OJD, [1873] s.d, p.87). Na prática, o que deveria ser um tempo de liberdade e prosperidade para o país foi um período de desconfiança, opressão e traições, que acabaram em execuções bárbaras saboreadas como se fossem espetáculos teatrais. 


\subsection{História dramatizada: A descoberta da Índia. contada por um marinheiro}

Como liberal e romântico que era, Pinheiro Chagas, atento ao cenário cultural português e da expressiva falta de instrução entre os seus patrícios, empenhou-se na difusão da história nacional num formato simples, atrativo e pitoresco, de modo que, ao mesmo tempo, instruísse e divertisse. ${ }^{133}$ Suas reflexões encaminhavam-se, por vezes, na direção de um país sem memórias, desconhecido de si mesmo, mais interessado na história do estrangeiro do que na nacional, principalmente entre a intelectualidade do país. Uma amostragem de tal inconformismo pode ser exemplificada por um trecho da introdução do artigo A narrativa histórica em Portugal, em que seu autor chega a advertir o leitor sobre haver:

[...] poucos países que tenham como o nosso uma história tão abundante em pitorescos episódios, haverá também poucos países cuja história seja tão completamente desconhecida não só pelo vulgo, mas também pela classe ilustrada, pela classe que devora os livros estrangeiros, que conhece a fundo os menores [sic] mistérios da corte de Luiz XIV, que é capaz de historiar, sem a mais leve hesitação, as intrigas e os combates da 'Fronde', as aventuras amorosas da corte de Luiz XV [...]

Pois esta mesma classe ilustrada, que se delicia com a leitura da história das nações estrangeiras, ignora completamente a história da sua pátria. E servindo-me do advérbio 'completamente' não quis fazer uma hipérbole ou arredondar o período; empreguei-o na sua mais ampla significação (CHAGAS, NEC, [1867] 1890, p. 47-48).

Páginas à frente, ele acrescenta mais informações sobre a historiografia nacional. Conforme Pinheiro Chagas, excetuando os livros de Alexandre Herculano, a história portuguesa - escrita por meia dúzia de cronistas - ganhara uma amplificação retórica nas atualizações feitas por alguns renomados escritores no período oitocentista. Nas suas abordagens, a visão apologética desses literatos transformou os antepassados portugueses em semideuses e os seus feitos em façanhas quase fantásticas. No entanto, não era só isso que preocupava o historiador e o romancista histórico. Chagas compreendia que a História

\footnotetext{
${ }^{133}$ Cf. Matos, 1998, p. 37. Apesar de ter havido muitos escritores desejosos de popularizar a história nacional, apenas dois historiadores, de formação bastante diversa, conseguiram se firmar junto ao público, sendo que seus compêndios foram adotados como verdadeiros modelos no gênero. Para Sérgio Campos Matos, ambas as historiografias tinham claras intenções pedagógicas de divulgação cultural, mas ele ressalta o traço compilatório dos estudos de Pinheiro Chagas, que se assume como tal: "[...] obra de divulgação baseada, sobretudo, em estudos, mas também em algumas fontes, foi escrita por um literato que, em rigor, não se pode considerar historiador. De resto, o autor assume inequivocamente o seu caráter de compilação". No que diz respeito a Oliveira Martins, frisa-lhe a competência intelectual e entende que sua história "[...] construiu [...] uma concepção original de vulgarização cultural completamente diversa daquela que até ao decênio de 1870 se conhecia”.
} 
referencial deveria se aproximar ao máximo da verdade verdadeira, razão pela qual era necessário se evitar, portanto, uma narração idealizada do fato ou o engrandecimento da imagem de seus protagonistas. ${ }^{134}$

Depois dessas colocações e após se observar os títulos no conjunto da obra deste escritor, embora ele tenha se dedicado a outros gêneros literários, o leitor percebe o enorme apreço que Pinheiro Chagas tinha pela História. Autor de alguns volumes relativos ao assunto, como a História de Portugal e História alegre de Portugal, seus romances históricos aparecem como um prolongamento dessa paixão, razão pela qual não é por acaso o fato de eles ocuparem boa parte de sua obra multiforme. Este tipo de romance não só foi alvo de criação, mas quase sempre era mote para o exercício do crítico que procurava defender uma concepção rigorosa do gênero. Para Chagas, o romancista histórico deveria buscar o equilíbrio adequado entre o argumento histórico e o ficcional. Caso houvesse excessos do primeiro elemento poderia incorrer na destruição do teor romanesco da diegese. Mas, por outro lado, o descuido com o aspecto documental prejudicaria o caráter histórico deste tipo de romance, em que a aventura e a intriga romanesca parecem ser as únicas preocupações do autor.

Apesar de, na maior parte de suas ficções históricas, Pinheiro Chagas ter dispensado muita atenção à trama romântica, ele estabelece para a sua terceira fase uma concepção de romance histórico convencionado de estudo histórico romântico. Uma espécie de narrativa em que o autor procura apenas dramatizar o episódio histórico, sem a intromissão de aspectos romanescos na história que relata. No entanto, nesse formato, encaixa-se fielmente apenas o último dos quatro romances, O naufrágio de Vicente Sodré de 1892, uma vez que os outros publicados em 1890, A Marquesa das Índia, A joia do vice-rei e A descoberta da Índia. contada por um marinheiro, há a presença de personagens inventadas e de cenas tipicamente românticas.

O período da História nacional privilegiado nesses quatro livros é o da descoberta e ocupação da Índia oriental. Pinheiro Chagas nessa reconstituição do passado português escolhe narrar não só as glórias, mas, principalmente, as veleidades e desavenças ocorridas no período áureo das grandes navegações.

\footnotetext{
${ }^{134}$ Ver Chagas, [1867] 1890, p. 49. No trecho em questão, o crítico estabelece o seguinte argumento: “[...] Estamos costumados a ver nas gerações que nos precederam umas coleções de vultos à parte, de gigantes que nada têm de humano, de heróis que passaram a vida a dar cutiladas, e que não sabiam combater bem senão na proporção de um contra duzentos. Quando os vultos da história assumem estas proporções fabulosas, não é possível distingui-los entre si, nem mesmo formar deles uma ideia muito exata. Os cronistas, que antes desejavam encher as suas páginas de retumbantes declamações do que transmitir às gerações futuras uma notícia singela dos grandes acontecimentos que presenciavam, erguiam-nos num pedestal, e mostravam-nos, envoltos numa nuvem, como os deuses de Homero, os grandes generais e os soldados valentões, os políticos eminentes e os fanáticos defensores da religião (grifo do autor)”.
} 
O quadro que eu procuro traçar não reproduz um acontecimento tão excepcional e tão dramático como o da descoberta da Índia, mas agrupa fatos bem interessantes para o conhecimento íntimo daquela época sem aparecer sempre uma solenidade que nos fatiga. São as intrigas abomináveis que se teciam em Lisboa para se disputar o comando de uma esquadra, as impressões que os hindus recebiam da aparição destes estranhos ocidentes, cuja religião tinha com a deles tão singulares relações, e finalmente as vilanias, que logo depois da gloriosa descoberta vieram infamar o nome português. A história tem duas faces, e nenhuma se deve ocultar. Não se deve ter para com os antepassados nem a admiração prudomesca nem o pessimismo desdenhoso (CHAGAS, ONVS, [1890] 1910, p. 8-9).

Como já explicitamos no segundo capítulo, a opção pelo período colonial para os seus romances históricos de 1890-1892, como todas as produções literárias do período do Ultimatum, representa a intenção autoral de explorar uma certa imagem da pátria decadente. Contudo, Pinheiro Chagas, desde os seus primeiros romances, parece ressaltar pelo menos um dos fatores deste decadentismo nacional, o pouco-caso português com as suas possessões, especialmente em decorrência da má administração por parte dos reis da casa de Bragança. Assim, os romances de terceira fase continuam destacando o reverso da moeda, narrando os episódios que foram excluídos dos manuais de História, como as intrigas e a ação ambiciosa dos portugueses em África oriental.

Mas, para reconstruir ficcionalmente estes períodos, era necessário, segundo Chagas, ter fontes documentais que pudessem facilmente “ [...] ver e perceber as fisionomias dos personagens, e adivinhar os sentimentos donde hão de brotar os dramas” (CHAGAS, ONVS,

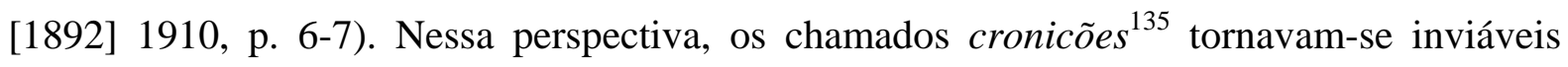
sob a alegação de que a verdade histórica - se esta existia nesses textos - estaria tão entranhada com elementos laudatórios e eruditos que dificilmente se compreenderia a real situação de uma época e de seus representantes.

[...] Os que põem estas histórias em livros não pensam senão em enfeitá-las ou então contar simplesmente as coisas grandes a que assistiram, de forma que nos dão ou palavreado bonito que para pouco serve, ou uma narração

\footnotetext{
${ }^{135}$ Ver Chagas, NEC, [1867] 1890, p.194. Um desses textos é Décadas, de João de Barros. Num artigo sobre a vida e a obra deste cronista do século XVI, apesar da notoriedade que este tinha no estrangeiro e em Portugal como grande historiador, Pinheiro Chagas considera que ele não soube esconder a sua parcialidade, não evitava os preconceitos cortesãos quando ia narrar fatos advindos de excluídos, como os indígenas. Uma frase que ilustra bem o que tentamos dizer é: “[...] Educado nos ares da corte, costumado, desde criança, a beber os seus preconceitos, a aceitar as suas ideias, valido de dois reis, escrevendo a pedido de um, cheio de benefícios do outro, João de Barros havia de observar tudo pelo prisma do cortesão. Mais preocupado em arredondar a sua frase do que em investigar as injustiças, as torpezas, os erros que se praticavam [...]”.
} 
que pouco interessa. $\mathrm{O}$ que eles deixam ficar no tinteiro são os casos miúdos, que contados por quem presenciou, parece que nos fazem viver a vida dos que os praticaram. Quando se conta falando, tudo então vem à boca, e, se eu conseguir passá-lo para a escritura, talvez os nossos netos leiam com mais prazer o que eu lhes contar do que lerão as crônicas em que os doutores muito sábios e muito latinistas escreverão as façanhas dos nossos portugueses, como se fossem de Gregos e de Romanos (CHAGAS, ADI, [1890] 1898, p. 4-6).

Por outro lado, parece-nos estranho que, no momento em que a História adquire o status de ciência, Pinheiro Chagas preterisse até mesmos os estudos históricos oitocentistas como orientador para a sua ficção ${ }^{136}$. Isso talvez porque, apesar das fragilidades ${ }^{137}$ das memórias, Chagas considerasse o conteúdo desta superior em qualidade documental à historiografia feita no seu tempo, que ainda demonstrava uma precariedade de fundamentação histórica. Além disso, o autor das memórias, como esclarece Joaquim Alves de Aguiar (1998), comporta as qualidades tanto do historiador como do cronista. Ou seja, o primeiro deles na busca de reproduzir, por meio da objetividade, a verdade do passado, e o segundo no sentido de poetizá-lo na mesma medida. Nessa base, as memórias consistiam em manuscritos fecundos e esclarecedores do viver das gerações passadas, pelo aspecto descritivo que fazia tanto da época como das paixões humanas.

Assim, para a composição de A descoberta da Índia. Contada por um marinheiro, Pinheiro Chagas se orienta pelos relatos de Lendas da Índia, de Gaspar Correia. Em sua opinião, este seria um dos textos mais importantes das letras portuguesas sobre os atos dos portugueses no oriente, tanto pelo seu caráter realístico, humano e pitoresco.

Nós não temos Memórias, mas para a nossa história da Índia temos as Lendas da Índia, de Gaspar Correia, o livro histórico mais valioso que possuímos, porque é o mais humano, o que nos mostra em traços realistas e familiares os caracteres dos homens e o aspecto dos acontecimentos. Não se pode prescindir do estudo apurado e continuado de Gaspar Correia quando se queira fazer a história séria e útil da nossa ação no Oriente no século XVI (IDEM, p. 8, grifo nosso).

\footnotetext{
${ }^{136}$ Ver Matos, 1998, p. 24-34. A partir do século XVIII, a ciência torna-se o único meio de se obter a verdade absoluta e objetiva. Quando ocorreu o academicismo da História, necessitou-se da profissionalização dos historiadores. Com isso, não se concebia mais que a História factual fosse ministrada e redigida por amadores (como literatos, cronistas, políticos, etc.). Em meados de oitocentos, sentiu-se a necessidade de uma divulgação da história entre as classes populares e o desejo de instruí-las quanto ao passado nacional.

${ }^{137}$ Cf. Chagas, ONVS, [1892] 1910, p.7. Todo texto em primeira pessoa, as impressões e os juízos de valor interferem consequentemente no relato. “ [...], há muitos [dados] em cuja narrativa [memorialística] se pode crer, mas em todo o caso, por maior que seja a boa fé do narrador, há sempre a descontar os erros que ele comete involuntariamente, graças ao prisma que a sua paixão política lhe impõe diante dos olhos, sem que ele dê por isso".
} 
O referido romance, de um modo geral, não é só interessante por dar voz a um excêntrico, mas ainda por sugerir que a crônica de Garcia Correia teria surgido das aventuras de uma personagem ficcional de Pinheiro Chagas.

[...] o que podeis, porém, Bastião, e nisso dareis grande prazer, é contar-me o que se passou nessa memorável viagem. Hei de por escrito tudo o que por cá fazemos e temos feito, e bem quisera eu apurar a verdade que anda já tão misturada com invenções e mentiras. [...] (CHAGAS, ADI, [1890] 1898, p.4).

Assim acabou o velho Bastião Fernandes a sua interessante narrativa, e queira Deus que possa ter dado tanto prazer aos meus leitores como deu de certo ao bom Gaspar Correia, constante investigador das tradições da descoberta e da conquista, que depois sabia narrar com tão impressionadora simplicidade (IDEM, p. 125).

A estratégia de converter um texto-destino (hipertexto) no lugar de um texto-origem (hipotexto) já havia sido usada por ele mesmo anos antes, quando da feitura de A mantilha de Beatriz. Ao final desta narrativa, Pinheiro Chagas surpreende o leitor desavisado, quando dá a entender que Calderón teria se apropriado do relato de seu herói como mote para uma de suas peças, Antes que todo es mi dama. ${ }^{138}$ Por este motivo, Maria de Fátima Marinho, em O outro Pinheiro Chagas, ${ }^{139}$ confere a este autor “[...] a modernidade de subverter o discurso do outro, negando-lhe originalidade, na estrutura de superfície, e reiterando a sua dívida na de profundidade” (MARINHO, 2005, p. 120).

Outra técnica utilizada em A descoberta da Índia consiste no que denominamos de histórias encaixadas ou mise en abyme. ${ }^{140}$ Essas histórias em cascata, numa leitura literal do termo literário, são imersas na narrativa encaixante. Entre elas se estabelecem múltiplos elos, que se desdobram em outras inúmeras histórias narradas. No romance em questão, a presença

\footnotetext{
${ }^{138}$ Ver Chagas, $A M B$, [1879] s.d, p. 174. “Assim foi alterando, modificando, cortando e acrescentando, segundo o seu direito de dramaturgo e de homem de gênio, Calderón da história que nós humildemente narramos fez o fundo da sua comédia Antes que todo es mi dama”.

${ }^{139}$ Ver Marinho, 1995, p. 109-120. A autora tenta desconstruir a ideia de epigonal dada a Pinheiro Chagas muito graças aos seus embates com a Geração de 70. Faz uma classificação de seus romances históricos pelo destaque que seu autor dá à História na intriga romanesca. Pontua, finalmente, que além da inclusão de interessantes estratégias na composição de seus livros, Pinheiro Chagas, pela criação de romances de cunho apologético, como os da fase final de sua carreira, é o precursor da literatura final de oitocentos e início da literatura de novecentos.

${ }^{140}$ Ver Moisés, 2004, p. 297-298. Expressão francesa que tem como tradução localização em abismo, pois consiste no encadeamento de objetos estéticos, um dentro do outro. O maior se desdobraria em várias partes semelhantes a ele.
} 
é sutil e são quase nulas as intervenções de um narrador central durante os relatos de Bastião Fernandes. $^{141}$

Quando o marinheiro chegou a este ponto, já a fusta abicara ao cais de Goa, mas Gaspar Correia interessara-se pela nossa narrativa, e pedira ao marinheiro que fosse contar-lha a sua casa. Na noite seguinte, Gaspar Correia, sentado no seu eirado, tendo mandado por uma garrafa de bom vinho do reino ao alcance do narrador, ouvia em silêncio a continuação da sua história (GHAGAS, [1890] 1898, p. 31, grifo nosso).

O primeiro narrador inicia o reconto de como o velho marinheiro Bastião Fernandes relatara suas aventuras e desventuras na expedição às Índias ao jovem Gaspar Correia, já que esta é a segunda narrativa, ${ }^{142}$ que, por outro lado, desdobra-se em outras pequenas histórias referentes às personagens secundárias do livro. O fato de Bastião ter se tornado personagem-narrador dá mais força ao caráter do drama, pois a personagem se torna palavra ${ }^{143}$ e só por meio desta se pode conhecer Bastião e as outras figuras da história contada. Mais à frente, discutiremos sobre este assunto mais detidamente.

Em nível linguístico, o coloquialismo de Bastião representa uma construção realística da personagem, já que se trata de um homem do povo. Neste sentido, a interferência do tom coloquial está em toda a narrativa, apresentando um vocabulário que vai desde expressões cotidianas até provérbios: "brutos de uma figa”, “com seiscentos”, “catinga”, "bestunto” e “com doidos ninguém se meta". ${ }^{144}$ Segundo o Dicionário de expressões populares portuguesas, de Guilherme Augusto Simões (1984), bestunto seria uma pessoa de juízo curto, de inteligência apagada (p.56). Brutos de uma figa refere-se a um indivíduo sem educação, indesejável (p.68). O adjetivo catinga está relacionado ao suor dos pretos (p.94). Já a expressão com seiscentos é sempre utilizada em frases que indicariam admiração, espanto ou terror (p.113). O aparecimento dessas inscrições linguísticas no texto é prova evidente da ocorrência do anacronismo necessário, tão defendido pelos romancistas históricos como a forma mais objetiva de serem entendidos pelos leitores de seu tempo.

\footnotetext{
${ }^{141}$ Em O major Napoleão, escrito em 1874, há a mesma estratégia literária, em que o primeiro narrador assume a responsabilidade da organização dos relatos e a sua edição, mas responsabiliza a testemunha pela veracidade das confidências.

${ }^{142} \mathrm{~A}$ segunda narrativa, que ocupa quase que completamente o espaço narrativo, é desencadeada pelas memórias de Bastião Fernandes, que - um pouco melancólico pela morte de Afonso de Albuquerque (um dos governadores da Índia portuguesa) e por rever novamente o porto índico - narra o tempo em que os portugueses avistaram pela primeira vez a Î́ndia para o jovem historiador Gaspar Correia.

${ }^{143}$ Ver Hamburger, 1975, p. 144.

${ }^{144}$ Ver Chagas, $A D I$, [1890] 1898, p. 8, 10, 12, 96, 63, na ordem de citação.
} 
Mas não só por esta estratégia linguística o autor se acerca do leitor. Ao colocar Gaspar Correia, como o interlocutor direto das memórias de Bastião, a personagem histórica se desdobra na imagem do leitor real deste livro. Por isso, as interpelações que o velho marinheiro faz direcionadas ao cronista, ao qual o próprio Bastião responde em seguida, ajudam não só no ritmo da movimentação dramática, mas têm como intenção convidar o leitor a entrar na esfera ficcional.

Não imaginais, sr. Gaspar Correia, o desconsolo que se apoderou de nós quando vimos que tínhamos outra vez que arcar com os temporais que já nos traziam arrasados. Que eles viessem, enfim, vá! Mas que fosse para irmos a terra onde se visse gente. Mas ali naquele sertão maldito, onde não havia senão penedos, areia e mais areia!... Como nós nos arrependíamos da alegria que tínhamos tido ao ver aquelas montanhas bem claramente que tínhamos dobrado o cabo!... Para que nos servira?... Quem nos dizia que não eram aqueles os portões do inferno? Se não havia ainda ondas de pez e de betume, é porque não é a entrada do inferno que tudo isso encontra [...] (CHAGAS, ADI, [1890] s.d, p. 53-54).

Além do mais, tais recursos favorecem que as cenas se sucedam, pois neste texto, que é praticamente um monólogo e exclui as poucas falas de Gaspar Correia e a do narrador primeiro, as outras são representadas pelo contador de histórias Bastião. Por isso, a ausência de narração, associada à presença de falas intercaladas, que muitas vezes são curtas, favorece a força dramática do texto, como no teatro. Um bom exemplo se pode ver no episódio em que Bastião vai requerer o seu soldo ao escrivão.

Quando chegou a minha vez, o escrivão perguntou:

- Tu o que és? Solteiro ou casado?

- Solteiro, respondi eu.

E suspirei.

- Ô rapaz, disse o sr. Vasco da Gama rindo, parece que não é lá muito por tua vontade.

- Ai! É sim sr. Capitão-mor, respondi eu revirando o barrete nos dedos. Nem eu faço tenção de casar.

- Então porque é que suspiras! ...

- Eu, sr. Capitão-mor? ...

- Sim; dize, homem de Deus!

- Pois então lá vai... É que eu sou solteiro isso é verdade, mas minha mãe é muito velhinha, coitada, e já nem tem outros filhos, que um morreu em Arzila, o outro filho tomado pelos patifes dos corsários barbarescos numa saltada que deram na Pederneira, e não se sabe onde para. E a velhinha coitada, assim que soube que eu partia, veio por aí fora a pé, e fica-me ao desamparo, sabe Deus por quanto tempo... Enfim, se eu morrer, sua alteza olhará por ela, mas, se não fora isto de eu ser solteiro, sessenta cruzados 
sempre eram mais um bocadinho de pão (CHAGAS, ADI, [1890] s.d, p. 2526).

É possível constatar que há uma mobilidade de câmera, que, comandada pela fala do personagem-narrador, sai da cena do marinheiro na negociação do seu salário e vai para a história da mãe velhinha, que perdera quase todos os seus filhos. Para um contador de história, todo fato se desdobra em outro e assim sucessivamente. Neste sentido, as memórias de Bastião são desencadeadas, por vezes, em outras histórias que não as suas, como se passa em outro episódio, o da escolha de Vasco da Gama para ser o capitão-mor da expedição:

Um dia, pois estava el-rei a despacho, sentado a uma mesa, que mandara por no vão de uma janela donde se avistava o Tejo, e donde ele podia ver o movimento e a azafama da gente da Ribeira das Naus, e também os navios novos que se balouçavam no rio que estava azul como o céu e claro como um espelho. E encostado a pena a boca, tendo o nome já meio assinado num despacho, cogitava em quem havia de ser o capitão-mor de tão grande expedição. Os seus oficiais não se atreviam a interrompê-lo, nem a tirar-lhe de diante o despacho que ainda não estava assinado de todo. De repente, sem razão nem motivo, o rei, que não tirava os olhos do Tejo, voltou-os para a sala, e dizia ele depois que sentira um baque no coração. Entrava nesse momento na sala, que atravessava nos bicos dos pés, para não interromper el-rei, um cavaleiro da sua casa, que era este mesmo Vasco da Gama (CHAGAS, ADI, [1890] 1898, p. 16-17).

Mas estas mesmas histórias que Bastião narra nos elucidam sobre sua visão de mundo como também ajudam na sua caracterização. Exemplo disso, é quando o narrador divaga sobre o mar e a mãe distante. De certa maneira, a existência do marinheiro é relativizada pelo existir de ambos, do mar e da mãe. ${ }^{145}$ A sua atenção é dividida entre duas mulheres, a mãe, que é aconchego e calmaria, e o mar, que é tormenta ou, melhor dizendo, “[...] la mar. Pois fêmea é que é este demônio. Diz-se mal dela, descompõe-se, e morre-se por ela” (CHAGAS, $A D I$, [1890] 1898, p. 87).

Já o seu lado místico é revelado pela presença de outro elemento da natureza, a lua. Nenhum outro astro fascina e exerce tanto poder sobre o homem e o mar como este satélite. Ciclicamente idênticos, o ser humano e a lua atravessam fases, desde o seu nascimento até a morte. A sua presença é associada à serenidade do homem e do mar, além do que ela está relacionada ao mistério e às divindades nas culturas pagãs ou cristãs. Por isso, embora pareça

\footnotetext{
${ }^{145}$ Por não ter um nome, acreditamos que ela signifique a coletividade.
} 
uma situação extremamente ridícula, quando Frade João ${ }^{146}$ e os tripulantes começam a rezar de joelhos quando veem a lua, parece-nos totalmente verossímil tal reação entre indivíduos isolados em alto mar e submetidos ao desconhecido. Na iminência da morte, o maior apego do homem passa a ser Deus.

Efetivamente a lua, nesse momento, rompia mansa e clara no céu em que as nuvens se rasgavam. Com o nascer da lua amainara o vento, e o mar aplacava as ondas. A sua luz serena espalhou-se por todos os pontos do horizonte, e não deixava lugar aos pesadelos da tormenta. Era tão boa, tão meiga aquela nossa companheira, que assim parecia vir trazer-nos saudades de Portugal, para que ficamos a olhar para ela embasbacados e agradecidos. A todos parece que acudiu a ideia de que na lua vinha, como num andor de prata, a Virgem Senhora Nossa, a nossa santa salvadora, porque, apenas fr. João caiu de joelhos, exclamando:

- Ave Maria, cheia de graça (IDEM, p. 44-45).

Os relatos de Bastião, construídos sempre numa perspectiva limitada e impressionista, vão nos fazendo conhecer desde o cotidiano nas embarcações até a cultura da Índia. Porém, muitas vezes, por sua condição social, o marinheiro é impedido de testemunhar. O autor, então, recorre a truques narrativos, colocando-o para auxiliar nos jantares dos capitães, ouvir atrás da porta e, em último caso, narrar o que lhe reportaram, como é o fato da escolha de Vasco da Gama para a viagem às Índias, que citamos anteriormente.

Como foi que o sr. Rei D. Manuel se lembrou do sr. Vasco da Gama, que tão arredado andara até aí destas coisas de mar? Diziam uns que fora por ele ser de Sines, terra de bons marinheiros, outros porque era filho de Estevão da Gama, [...] veador que foi de El rei D. Afonso V, coisa que o sr. D. Manuel sempre atendia muito, mais desejoso de honrar os que tinham servido seu tio do que os que tinham sido escolhidos por seu primo, outros porque muito se empenhara por ele sua irmã, a senhora rainha D. Leonor. Mas eu vou narrar-vos, sr. Gaspar Correia, o que ouvi a um marinheiro muito amigo meu, de que, adiante terei de vos falar. Era colaço de um filho do sr. Nicolau

\footnotetext{
${ }^{146}$ Ver Correia, Lendas da Índia, s.d, p. 135. A presença desta figura referencial ajuda a credibilizar o inusitado relato. Vale acrescentar que muitas crônicas quinhentistas tiveram suas origens nos relatos de alguns viajantes, como os de João Figueira, que anotava todos os dias as ocorrências de sua viagem às Índias. Valorizados por Bastião e desacreditados por Gaspar Correia, os relatos de Padre João aparecem na narrativa simbolizando textos que acabavam se tornando eruditos, pois privilegiavam as grandes figuras da história, muito porque estes escritos eram financiados pela nobreza. Assim escreveu Gaspar Correia sobre isso: “[...] o que também fez um clérigo da nau chamado João Figueira, que tomou de sua vontade escrever tudo o que nesta viagem se passou; que chegou a Melinde [...]. Então, cuidando que havia de morrer, deu ao capitão um caderno em que tudo tinha escrito, com que muito folgou, e partindo de Melinde lhe encomendou que assim escrevesse, depois se fizeram muitos traslados, de que eu vi os pedaços de um deles em poder de D. Afonso de Albuquerque, ante uns papéis velhos, que eu, Gaspar Correia, servi três anos de seu escrivão, pelo que, vendo tão gostosa coisa para folgar de ouvir e saber, recolhi este caderno já feito em pedaços e roto por partes: pelo que tomei em vontade escrever tudo quanto pudesse alcançar e ver dos feitos da Índia, de que já dei minhas desculpas, que muito peço por mercê aos senhores leitores que me recebam, e levem em conta minha ignorância com que neste erro sou caído".
} 
Coelho, e sabeis que Nicolau Coelho era com o sr. D. Vasco, pode-se dizer, unha e carne (CHAGAS, ADI, [1890] 1898, p. 16).

No referido episódio, mesmo havendo transcrições literais de falas de Vasco da Gama com El Rei nas crônicas de Gaspar Correia, muita coisa foi suprimida em favor da ação romanesca. Além disso, outros cortes foram necessários, até mesmo como forma de não estender a narração com partes da História já um tanto conhecida. Nos trechos em questão, o narrador prefere se abster do reconto sob a alegação de que a sua condição de marinheiro o restringia de conhecer assuntos relacionados à sala dos capitães. Embora esta seja mais uma das inúmeras maneiras de credibilizar o que se conta, o trecho também possibilita entender que o campo de visão do memorialista é totalmente distinto daquele do historiador, que tem uma visão mais ampla sobre o fato. Mas, mesmo assim, para Hayden White, “os historiadores em geral, por mais críticos que sejam de suas fontes, tendem a ser ingênuos contadores de histórias” (WHITE, Nota de rodapé, 2008, p. 24). Esta afirmativa parece simplificar os conceitos que Pinheiro Chagas tinha para si de narrar e historiar. Não é à toa que o marinheiro Bastião, figurando como um contador de histórias, de certa forma, torna-se historiador, mesmo com amadorismo, ao relatar a Gaspar Correia os acontecimentos da primeira viagem expansionista às Índias.

E, assim, as memórias de Bastião vão tomando corpo, ditadas pela subjetividade e ordenadas segundo a sua prerrogativa. Desta forma, a não linearidade do seu reconto acaba subvertendo a cronologia imposta pelos historiadores, mesmo se tratando de uma parte da historia nacional. Ao fazer isso, em certa medida, Pinheiro Chagas confirma a sua ideia de fazer História. Mesmo esta sendo sempre orientada pela objetividade, tal prática não a diferencia da narrativa literária, que deve ser escrita de maneira realista, inteligível e interessante, de maneira que realmente entretenha e instrua o leitor.

Nesta perspectiva, a sua proposta se realiza quando ele opta por uma espécie de contador de histórias, como se fazia na Antiguidade, quando a tradição era repassada por meio do conto, ponto sobre o qual voltaremos a discutir na seção que se segue. 


\subsubsection{Bastião Fernandes, um contador de histórias com História}

Quando se lê A história alegre de Portugal, publicada em 1880, e, por outro lado, analisa-se a seguinte sentença de Pinheiro Chagas - “[...] os fatos narrados, mesmo aqueles em que só figuram personagens que existiram, são de pura fantasia [...]” (CHAGAS, AJVR, s.d [1890], p. 7) -, percebe-se que o projeto literário que este autor desejou concretizar não fazia distinção entre as duas disciplinas: história e literatura. Pelo contrário, o que se depreende é que, para ele, tanto uma quanto a outra são narrações, mas com funcionalidades diferentes: a primeira com o propósito de provar e a segunda apenas de narrar.

Adepto do princípio aristotélico, Pinheiro Chagas considerava o poeta uma entidade superior a do historiador, porque o poeta poderia se utilizar do seu poder de invenção para contar algo que não ocorrera, enquanto o historiador não fazia mais do que transferir para o papel o que outros falavam e escreviam. Por outro lado, sobre esta questão, Marcelino Menéndez Pelayo, citado por Kurt Spang, julgava que a reconstrução do passado empreendida pelos historiadores oficiais (embora estes se baseassem numa objetividade) necessitava do caráter inventivo no momento de ordenação dos fatos, em suas supressões e, principalmente, quando fossem dar unidade à narração:

[...] la pura creación de la fantasia poética toma forma y desarollo análogo a los de historia y aún se confunde con ella cuando el prestigio del genio creador llega a tanto, adquiriendo entonces cierto género de vida muy positiva los personajes poéticos. Por otra parte, tampoco puede decirse que la historia viva sólo de verdades positivas e incontrovertibles, sino que entran en ella, por grandísima parte, lo inverosímil, lo conjetural y lo opinable (PELAYO, 1942, p.36 apud SPANG, 1998, p. 12-13).

Por isso, não nos surpreende o tom ficcional dado para A história alegre de Portugal, ${ }^{147}$ que é um tipo de produção historiográfica destinada à instrução sobre o passado nacional nos liceus. Contudo, este atributo não impediu que a obra fosse adotada pelo público em geral. ${ }^{148}$ Classificada como historiografia de divulgação, esta teve um destaque, que se deu quase que

\footnotetext{
${ }^{147}$ Ver Chagas, HAP, [1880] s.d, prólogo. Segundo o autor, depois da leitura de um livro intitulado Entretiens populaires sur l'histoire de France, atendendo a uma sugestão do amigo Miguel Dantas, decidiu fazer algo parecido com a história de Portugal, seguindo o plano em "[...] tom faceto, folgazão, singelo e popular que achei original, picante e útil [...]”.

${ }^{148}$ Cf. Matos, 1998, p. 34. Muitos historiadores e literatos se empenharam arduamente na formação de uma consciência histórica entre os portugueses. Contudo, havia entre os escritores uma preocupação quanto à necessidade de se diferenciar os compêndios escolares, estritamente didáticos, dos que eram destinados à formação do público em geral. No entanto, o que acontecia contrariava o desejo dos autores, pois muitos livros didáticos sobre história eram adotados desde a educação básica até o curso profissionalizante e também pelo público externo às escolas.
} 
essencialmente pela técnica narrativa empregada, por seus aspectos morais e pela utilização do descritivismo das crônicas. Especificamente no tocante a este livro, Chagas tendeu a inserir elementos dialógicos na narrativa, quebrando a continuidade da História oficial. Para isso, o autor inventou um narrador, chamado João Agualva, professor aposentado, que cansado de repetir histórias da carochinha - decidiu narrar em dez aprazíveis sessões as inúmeras peripécias, começando pela fundação de Portugal até a contemporaneidade do autor. Escuta estas histórias um grupo de camponeses: tia Margarida, o Francisco Artilheiro, o velho Bartolomeu, o Manuel da Idanha e o Zé Carneira. A forma criativa com que Pinheiro Chagas enlaça o elemento factual à ação romanesca não coloca em risco o rigor histórico, sempre exigível em textos desta índole. Por exemplo, as dúvidas que os ouvintes apresentavam são vistas como mero pretexto para que se conte um outro episódio ou se elucide questões obscuras da história nacional. Sobre esta singularidade na obra de Chagas, na opinião de Campos Matos, “[...] os diálogos não deixam, por vezes, de imprimir uma certa vivacidade ao conjunto” (MATOS, 1998, p. 33).

Outra interessante característica apresentada neste volume de Pinheiro Chagas é a maneira como se dá a narração da História nacional, que é muito aproximada ao entrecho de Decamerão, de Giovanni Boccaccio. Nesta obra, os contadores de histórias, três homens e sete mulheres, revezam-se em torno de um mote, proposto em cada uma das dez jornadas, para entreter os outros durante o temor advindo da peste negra. Percebe-se, a partir disso, como Boccaccio, com extrema habilidade ficcional, consegue detalhar realisticamente o período, recriando uma atmosfera de desordem social, ruína e opressão com o risco iminente de morte. À medida que se faz a leitura do texto florentino, o leitor entende que contar histórias torna-se um passaporte para o plano simbólico de conforto e prazer, deixando para trás um ambiente apocalíptico.

Mas esta estrutura do livro florentino é recuperada novamente em outra obra de Pinheiro Chagas, A lenda da meia-noite (1874). Como apontado por Helena Carvalhão Buescu (1997), tal como o Decamerão, o enredo da obra portuguesa trata de um grupo de amigos hospedados em um castelo abandonado que resolve contar histórias encomendadas, só que, agora, para espantar o medo da meia-noite. Os cinco $\operatorname{contos}^{149}$ organizados neste volume, por meio do

\footnotetext{
${ }^{149}$ Publicados no Arquivo pitoresco em 1864: Memórias de uma bolsa verde, Julieta (o único nomeadamente conto fantástico), A visão do precipício, A igreja profanada e Dominus tecum. Como o primeiro conto será discutido, daremos o resumo a partir do segundo conto. Narrada em primeira pessoa, esta trama é uma aventura amorosa em clima de alucinação e com um desfecho necrófilo. No segundo, os personagens deste conto narram uma lenda fantasmagórica; então, desta forma, teremos dentro de uma estória maior dois desmembramentos. A lenda narrada em um estilo ultrarromântico conta-nos a estória de Branca, que se suicida por ter sido abandonada por seu noivo, Raimundo, que se apaixonara por uma moura, Zoraida. Diante da blasfêmia, Raimundo também
} 
recurso narrativo mise en abyme, ganham unidade com a narração de personagens/narradores. Nesse sentido, todas as estórias aqui narradas - umas mais, outras menos - foram feitas seguindo-se a linha da literatura gótica ou de terror. ${ }^{150}$ Para isso, não poderiam faltar ingredientes básicos, como os elementos sobrenaturais, os temas de morte, lugares sombrios e fantasmagóricos ${ }^{151}$.

Proponho que organizemos um Decamerão para zombarmos da meia-noite, como os narradores de Boccaccio zombaram da peste de Florença. Cada um de nós, que se sentir para isso com forças, se compromete a compor uma história fantástica, uma lenda, um conto maravilhoso que será lido aqui ao bater da meia-noite. Dessa forma afrontamos face a face a terrível inimiga do repouso da Sra. D. Isaura, e, se ela ainda usar fazer uso dos seus sortilégios, conosco se há-de haver (CHAGAS, ALMN, [1874] 1890, p. 15).

Por seu turno, este encadeamento de narrativas favorece a metaficção, ${ }^{152}$ como se pode ver em Memórias de uma bolsa verde ${ }^{153}$. O que se percebe, afinal, é que era um hábito entre os escritores oitocentistas incluir, em suas criações ficcionais, reflexões sobre elementos de

seria castigado pelas forças sobrenaturais, por ter desrespeitado a imagem de Cristo. Contudo, Branca ressurge na figura de um anjo e o salva da condenação. O terceiro conto segue a mesma organização de $A$ visão do precipício, pois dois barqueiros, depois de verem um fantasma andando sobre as águas, contam-nos sobre a estória de dois irmãos que praticaram incesto e davam inúmeras orgias. O último ato imoral fora profanar a igreja local, ato repudiado pelo sacerdote, que, ao defender a casa de Deus, é assassinado por Guilherme. Pinheiro Chagas adverte em uma nota de rodapé que esta lenda não é de todo inédita, pois se tomou como base um livro de Conde de Résie, intitulado História e tratado das ciências ocultas. A última narrativa fantástica é destinada às crianças. Nesta, há um duende de mais de mil anos que deseja desposar uma jovem camponesa de vinte anos. Para que isso se realize, ele lança um feitiço que funciona assim: se ninguém falar "Dominus tecum" a uma moça que der o terceiro espirro, ela será a noiva dele. Contudo, um homem que fora escravizado, sabendo das intenções do duende, diz ao terceiro espirro a palavra mágica, livrando a moça das garras do seu mestre.

${ }^{150}$ Cf. Sousa, 1987, p. 35-36. As ideias deste tipo de literatura chegaram a Portugal de maneira distorcida, pois o terror e o sobrenatural das estórias eram amenizados pelas traduções censuradas, bem como pela falta de critério dos tradutores na escolha de seus originais. "Um fator muito importante a considerar na atividade selecionadora, se é que alguma havia, das novelas a traduzir, era a censura. Para os rígidos puritanos, a quem o cuidado de olhar pela moralidade pública estava confiado, tudo o que vinha de Paris cheirava a heresia e a escândalo. Ajudados pelos vizinhos espanhóis, ainda mais rigorosos, e até pela opinião pública, o seu trabalho estava simplificado. De resto, só com a instauração do Liberalismo e o regresso definitivo dos emigrados soprariam com força os ventos da cultura europeia”.

${ }^{151}$ Pinheiro Chagas, como crítico/leitor voraz que era, privilegiou tais escritos, desde literaturas cânonicas às incipientes, como foi o caso da literatura brasileira. Certamente, Chagas sofreu uma influência tanto da escola francesa, com Eugene Sue, como dos precursores da literatura gótica inglesa, como Ann Radcliffe. Tanto assim que os cita em sua obra em algumas passagens: “- Oh! Meu Deus, accudiu o escritor, não é difícil de adivinhar. O doutor entende que as lendas devem ser lidas e apreciadas à noite, no meio do silêncio geral, quando se está sozinho, n'um velho castelo de Ann Radcliffe, cheio de alçapões e de subterrâneos, quando o vento geme lugubremente nos corredores, e faz oscilar a luz da vela que alumia a nossa solitária vigília (CHAGAS, ALMN, [1874] 1890, p. 7).

${ }^{152}$ Segundo Hutcheon, 1984, p.1. Este recurso favorece que o narrador reflita sobre sua escrita, compartilhando com o leitor as incertezas e certezas da criação artística. "É a ficção acerca da ficção, isto é, a ficção que inclui no seu magma o comentário à própria narrativa e/ou à sua identidade linguística”.

${ }^{153}$ Aqui, o primeiro narrador, o escritor Lúcio Valença, conta-nos uma estória fantástica de uma bolsa verde escritora, que ele havia arrematado num leilão. Num dia em que ele não conseguia escrever, a bolsa, que se transforma numa segunda narradora, inerte em seu canto, ao perceber a angústia de seu dono, decide ajudá-lo, contando-lhe o que acontecera com ela desde o seu "nascimento" até o dia em que foi parar na casa do escritor. 
narratologia e verossimilhança, quase sempre sob o sabor da ironia. Nesse conto, por exemplo, a protagonista, uma bolsa-narradora, critica veladamente estilos de autores que se preocupam mais com a descrição exaustiva do pormenor do que com a própria invenção. Além disso, ela comenta sobre questões de estilo e ainda apresenta sumariamente os elementos necessários à manutenção do interesse do leitor/ouvinte na hora do conto. Este último comentário caracteriza-se em uma alfinetada no gosto popular que, independente da narrativa ser boa ou ruim, interessava-se apenas pelos ingredientes românticos - tais como crimes, desejos de vingança, raptos de donzelas, casamentos depois de longas expiações, dentre outros - encontrados nos diversos folhetins da época. Para ilustrar nossa explanação, disponibilizamos o seguinte trecho, escrito quase ao final do conto, quando a narradora repensa a maneira como elaborou suas memórias:

Agora percebo eu que fui pouco hábil na narração. Pois não o devia ser; porque na estante do literato conversara muitas vezes com uma coleção da Presse e do Constitutionnel; e os folhetins romances destes jornais tinhamme ensinado todos os estratagemas, com que se tem suspensa a curiosidade do leitor, incitando, aguilhoando-o com a espora do mistério, de forma que ele percorra a narração, como um cavalo desenfreado percorre a planície sem se preocupar com as belezas dos acessórios, e desejando só chegar ao fim, que é para o cavalo o precipício em que se despenha, para o leitor a peripécia última, que se pode compor, à vontade do romancista, ou de trinta punhaladas, ou de vinte casamentos (CHAGAS, ALMN [1874] 1890, p. 187-188).

Neste conto, além das discussões relativas à criação artística, há ainda comentários sobre a profissionalização das letras. Entre os temas mais abordados, a bolsa denuncia a dedicação exaustiva dos escritores às traduções e aos folhetins encomendados, que consistiam na certeza de manter as contas em dia. Às vezes, o difícil não era escrever, mas encontrar um editor para publicar seus manuscritos. Num tom irônico, a bolsa desabafa:

[...] vendo o meu dono passear mo quarto, sempre agitado, e sempre procurando alguma coisa, ou uma rima, ou um lenço de assuar, ou um editor.

Rimas encontrava ele quase sempre, lenços de assoar algumas vezes, editores nunca!

A traça fora o editor único daqueles papéis (CHAGAS, ALMN, [1874] 1890, p. 184). 
Depois do exposto, restaria assinalar que essa inclinação em criar homens-narrativa, seguindo-se uma denominação todoroviana, que educam por meio da narração, tem o lúcido propósito de transformar cada uma dessas entidades ficcionais em verdadeiros guardiões da tradição. Independentemente do fato de que a obra seja considerada um romance histórico ou um romance de atualidade, sempre se pode encontrar o trânsito de contadores de histórias nesses espaços narrativos, sejam objetos inanimados (como a bolsa verde), ou gente do povo (como a cozinheira Tia Quitéria, de A flor seca, e o barqueiro João Moedor, de A visão do precipício), que são apenas alguns nomes entre outros tantos.

Quando se percebe esse número expressivo de personagens-narradores no projeto literário de um escritor não se pode falar em coincidências. Parece haver uma similaridade entre as ideias de Chagas com aquelas divulgadas um século depois por Michel Foucault. Na sua conferência $O$ que é um autor?, o filósofo francês abordou a relação intrínseca que há entre a arte de narrar e o desejo de não morrer. Para ele, desde a Antiguidade, a narrativa tentava subverter a iminência de uma morte inevitável, principalmente entre os guerreiros, que morriam muito cedo, mas que sobreviviam no imaginário daqueles que recontavam suas façanhas nas epopeias. Foucault, no mesmo espaço, considerou que as narrativas árabes, como As mil e uma noites, ilustram bem a metáfora de postergar a morte. Sob uma análise mais detida de tais textos, realmente é isto o que ocorre: o narrador, ao passar de uma história para outra, desencadeia uma gama de narrativas sem fim. Então,

[...] falava-se, narrava-se até o amanhecer para afastar a morte, para adiar o prazo desse desenlace, que deveria fechar a boca do narrador. A narrativa de Shehrazade é o avesso encarniçado do assassínio, é o esforço de todas as noites para conseguir manter a morte fora do ciclo da existência (FOUCAULT, 2006, p. 268).

Além da intenção de manter viva a tradição, existem ainda outros atributos relacionados ao ato de narrar, como a forma de amenizar o sentimento da saudade a tudo o que remete à terra natal, apaziguando, ainda que transitoriamente, tanto o espírito inquieto e melancólico de quem conta quanto o de quem ouve os relatos do passado. Num dado momento de suas crônicas de viagem, o personagem-narrador traça os seguintes comentários: “Quando íamos longe uns dos outros, cada um se entretinha como podia. À noite, nos quartos de vigília, era tudo contar histórias, e lembramo-nos das nossas terras e das nossas famílias, e narrávamos o que nos sucedera em Lisboa” (CHAGAS, [1890], 1898, p. 32, grifo nosso). Dessa maneira, a inquietude do espírito só se acalma por meio da rememoração, na hora de contar os causos do 
passado. Na maior parte do tempo, os sentimentos e as intenções desses viajantes tomam dimensões hiperbólicas, razão pela qual não há como estranhar a declaração apologética do narrador Bastião ao deixar Melinde:

Por aqui passei eu. E quando, depois, nós partimos, e o sol brilhante se espalhou no mar, e nós vimos ao longe, no alto do seu outeiro, aquelas colunas muito brancas onde brilhava com toda a luz, no ouro das suas letras, o nome do rei Manuel, todos pensamos que podíamos naufragar, morrer, nunca mais voltar à nossa terra, mas que aquele era o nosso testamento, e um testamento que ninguém podia rasgar. E também dizia eu cá no meu bestunto, ainda que nossa terra se vá toda por água abaixo, e que já ninguém fale em Portugal, aquelas colunas, aqueles padrões hão de ficar como essas pegadas de gigantes, que a gente depois encontrou na Índia. Não é verdade, sr. Gaspar Correia? (IDEM, p. 95-96).

O relato vai ganhando pessoalidade à medida que as suas aventuras a caminho das Índias tornam-se conhecidas do leitor. Pela narrativa, é possível conhecer elementos particulares, como as devoções, os temores ao desconhecido e as superstições que a marujada demonstrava em situações extremas no mar, que ora incitava amor, ora ódio. Uma das passagens mais enigmáticas de suas memórias é quando a esquadra de Vasco da Gama dobra o Cabo da Boa Esperança e Bastião, atormentado pela iminência da morte numa tempestade terrível, vê um vulto enorme a lhes impedir a passagem. Nesse instante, o marinheiro tenta em vão mostrar aos outros companheiros o que vira, mas eles não conseguem ver nada.

Ah! Sr. Gaspar Correia, não sei como se formara aquela visão na minha alma: o que eu vi, juro pela alma de minha mãe, o que eu vi, quando o raio iluminou o céu e o mar, foi para o lado de leste uma sombra imensa que me pareceu uma figura com o braço estendido, uma daquelas estátuas que os nossos diziam que se levantavam como sentinelas no mar para proibirem a passagem. Todos olharam ansiosos e trêmulos para o sítio que eu indicara; mas, quando veio outro relâmpago, não vimos já para esse lado senão as montanhas de água a encavalarem-se por cima umas das outras (IDEM, p. 44).

Bastião, enquanto entidade ficcional ${ }^{154}$, não se encaixa no modelo romântico, que ressalta qualidades nobres, como bravura e lealdade. Como um anti-herói, dono de atitudes

\footnotetext{
${ }^{154}$ Ver Chagas, ONVS, [1892] 1910, p.8. Ao término da leitura sobre as memórias do marinheiro Bastião, o leitor crê fielmente que ele existiu, mas na introdução de $O$ naufrágio de Vicente Sodré se descobre que ele é filho da imaginação. "Na descoberta da Índia inda fantasiei um ou dois personagens, o marinheiro Bastião Fernandes e a sua velha mãe, mas o marinheiro era tão visivelmente a personificação da marinhagem, que me não deixou remorsos a invenção".
} 
pouco nobres, ele se amedronta, como na passagem do cabo; ouve conversas atrás da porta ${ }^{155}$ e chega a ponto de delatar seus companheiros de navio no momento de motim. Após o acontecimento, utiliza-se do seguinte argumento como justificativa: “[...] não tivera outro intento senão salvar a vida dos nossos capitães [...]” (CHAGAS, ADI, [1890] 1898, p. 67). No entanto, parecia ser mais rentável para Bastião ser bem visto por seus superiores do que participar de uma rebelião no calor da hora. Desde o instante em que ele tomou conhecimento da revolta, quando fingia estar dormindo para não levantar suspeita, ele já dava mostras do grupo a que servia. A nosso ver, fora decisivo para isso o instante em que Vasco da Gama revê o soldo de Bastião, que ganharia menos só por ser solteiro. ${ }^{156}$

Como na referida cena, a convivência verossímil entre personagens referenciais e inventados é uma das atenções que o romancista deve ter na recriação do passado nacional. Por isso, a vida dos tipos ficcionais é entrelaçada ao fato histórico, de modo que o autor se acautela para não cair em contradição com a verdade histórica. No caso específico deste romance, tanto o episódio histórico quanto as individualidades daquela época são retratados sob um novo foco, agora de baixo para cima.

Assim, independentemente de qual seja o objetivo da narração, a identidade do contador está em muitos traços da história que ele narra, e isso pode ser visto pelas incontáveis direções que ele dá aos fragmentos da narrativa que, no final, forma o todo. Portanto, o todo narrado é algo que se constrói a partir das escolhas individuais de cada contador. Sobre isso, Walter Benjamin entendia a narrativa como uma forma artesanal de comunicação. No seu parecer,

[...] [a narrativa] não está interessada em transmitir o 'puro em si' da coisa narrada como uma informação ou um relatório. Ela mergulha a coisa na vida do narrador para em seguida retirá-la dele. Assim se imprime na narrativa a marca do narrador, como a mão do oleiro na argila do vaso. (BENJAMIN, 1987, p. 198).

Bastião à medida que vai narrando o episódio da descoberta das Índias vai imprimindo sua subjetividade no relato. Mesmo que seja uma parte da História muito conhecida, a seleção de cenas e a sua recriação em maior ou menor espaço consistem em elementos que nos

\footnotetext{
${ }^{155}$ Mesmo sabendo que isso se trata de uma estratégia para dar crédito ao seu relato, que se dá numa perspectiva limitada, como já dissemos, salientamos que esta atitude, por não ser ética, distancia-se da concepção que se tem de herói, um ser dotado de valores e princípios morais rígidos.

${ }^{156}$ Ver Chagas, $A D I$ [1890] 1898, p. 26 e 50: “[...] Escrivão, dai a este homem cem cruzados em vez de quarenta. Os sessenta ficam por minha conta. Este é casado com a mãe. [...] Eu fiquei turvado com a lembrança daquele senhor, que os olhos arrasaram-se-me de água, e não soube o que havia de responder. A minha pobre velhinha! Mal sabia ela na sua pederneira, a essas horas, que um tão grande fidalgo, homem de prol, que valia mais que todos os reis e imperadores do mundo, estava bebendo à sua saúde”.
} 
evidenciam as intenções do autor. Não existe, portanto, só uma interpretação do fato, mas variadas leituras, dependendo do prisma com o qual se olha. E, nestas releituras, abrem-se possibilidades para se recuperar muitos nomes à sombra na História oficial.

A própria presença de um marinheiro como narrador, representante da classe popular, já é um ajuste de contas com a História oficial. Além disso, em A descoberta da Índia, quando seu autor coloca no seu espaço ficcional Gaspar Correia como interlocutor do reconto das memórias do velho marinheiro, percebe-se o claro objetivo de recuperar uma outra imagem do cronista. Chagas considerava que o autor de Lendas da Índia fora um injustiçado junto à crítica portuguesa, que resumia toda a produção do século XVI nas crônicas de João de Barros. No entanto, o romancista oitocentista não esconde a sua predileção pela escritura de Gaspar Correia. Certamente, esta admiração consistia na dramaticidade da cena que ele criava, na maneira como descrevia realisticamente o episódio histórico, inserindo diálogos sempre que isso fosse necessário. Depois de uma leitura dos textos de Correia, percebemos que o cronista evitava dar espaços para divagações e declamações. Os seus períodos oracionais são breves. E nos momentos em que existe a necessidade de explicações ou referências aos fatos, eles ocorrem de modo objetivo, mas esclarecedor.

Outras críticas, como a de Rodrigo Felner (1858), contemporâneo de Chagas, atentamnos para o fato de que a denominação de lenda assenta bem à referida produção de Gaspar Correia, pela inclinação, que existe às vezes, ao romanesco e ao maravilhoso, embora estes elementos, como bem adverte o crítico, sejam incompatíveis com a gravidade da História. Acrescido a isso, ele ressalta a ocorrência de alguns erros cronológicos, que possivelmente sejam devidos à falta de documentação. Embora Felner aponte com justiça algumas fragilidades nas crônicas de Gaspar Correia, ele reconhece em tais escritos suas qualidades narrativas, no que tange ao realismo e à poesia com que o autor descreve a viagem às Índias:

[...] porque viu a maior parte dos feitos, e mesmo os que não viu narra por miúdo, guiando-se não por tradições remotas e incertas, mas por informações fidedignas. [...]

[...] O estilo destas lendas não deixa de ser difuso, redundante e desataviado de mais; mas da sua singela, e da verdade absoluta das descrições a que os artifícios retóricos tanta vez empanam o brilho, deriva a força que nos põem redivivos diante dos olhos os quadros que inspirou o sentimento e a observação, e a imaginação aceita como fixados na tela (FELNER, Nota preliminar, tomo I, 1858, p. XIII-XXVIII).

Felner acaba concluindo o seu pensamento sobre a maestria dos relatos de Correia numa única expressão: “[...] sem arte, ninguém os escreveu com mais arte” (IDEM, p. 28). De outro 
lado, Aurélio de Oliveira (1998), apesar de não fazer referência ao estilo diferenciado de Gaspar Correia, não deixa de citar que ele era o decano dos historiadores dos feitos da Índia, ainda que muito menos divulgado do que João de Barros.

Nesse romance histórico, outra preocupação de Pinheiro Chagas é retratar os grandes vultos históricos de maneira desromantizada. Por isso, Vasco da Gama figura como homem que oscila entre a severidade e a bondade. Quando descobre o motim da tripulação, Gama, furioso e ensandecido, prende os pilotos e joga ao mar todas as cartas de navegação. No entanto, só se conhece a verdadeira índole do ilustre capitão quando, depois de sua libertação, jura vingança pelo tratamento recebido em Calicute.

- Ah! Terra infame de tredos e de vis! Eu voltarei à Índia, mas juro-vos que hei de tirar vingança terrível das vossas traições e dos vossos maus-tratos.

$\mathrm{E}$ os olhos luziam-lhe, e tremiam-lhe os beiços, e os punhos fechados, estendidos para a cidade, pareciam querer esmagá-la (CHAGAS, ADI, [1890] s.d, p. 113).

Embora Bastião tivesse o conhecimento das atrocidades que o navegador fizera no seu retorno às Índias, ele ameniza o ato de barbárie com a justificativa de que isso seria uma resposta às intensas humilhações que Vasco da Gama passara em Calicute:

Ah! Sr. Gaspar Correia, quando me lembro das barbaridades que o sr. D. Vasco veio a praticar, da segunda vez que foi à Índia, ele que eu conhecera tão bom e tão caridoso [novamente o reforço à imagem de benevolente atrelada à intervenção de Gama na revisão do salário de Bastião], pensei que talvez para isso concorressem aqueles dias de reprimida fúria, em que tanto havia de sofrer, mas em silêncio, o seu orgulho ferido [...].

[...] Não parou nisso o capitão-mor, porque saltou depois com os batéis nas fustas aos tiros e à bordoada, matando sem dó nem piedade os primeiros que fugiram. Não era culpa para tamanho castigo, mas o sr. Vasco da Gama queria que na Índia se ficasse sabendo como os portugueses mordiam (IBIDEM, p. 114-119).

Vasco da Gama aparece novamente, em O naufrágio de Vicente Sodré ${ }^{157}$, como um $\operatorname{arrogante~e~genioso~}^{158}$, não medindo esforços para conseguir seus propósitos. Caso ilustrativo disso é a sua disputa com Pedro Álvares Cabral para o cargo de capitão-mor da armada para a segunda viagem às Índias. Esta imagem mais humanizada do vulto histórico é uma das

\footnotetext{
${ }^{157} \mathrm{O}$ leitor que sentir interesse pelo tema poderá continuar a sua leitura em O naufrágio de Vicente Sodré, livro no qual se encontram intrigas de corte e os atos de vilanias dos portugueses em Índia.

${ }^{158}$ Ver Chagas, ONVS, [1892] 1910, p. 19-37. Tais considerações podem ser constatadas nos capítulos que se intitulam Fraquezas de um grande homem e As intrigas do comando. " O leão rugia, e El-Rei empalideceu. Pode nesse momento compreender como fora que no mar alto, no meio das tempestades, a vontade de ferro de Vasco da Gama quebrara as mais rijas temperas de marinheiros. Para poder lidar vitoriosamente com homens daqueles, só D. João II”.
} 
propostas do ficcionista ao entender que “[...] a história tem duas faces, e nenhuma se deve ocultar. Não se deve ter para com os nossos antepassados nem a admiração prudomesca nem o pessimismo desdenhoso [...]” (CHAGAS, ONVS, [1892] 1910, p. 9).

Ainda sob a proposta de mostrar os defeitos e as fraquezas dos seus ancestrais, Pinheiro Chagas, em A joia do vice-rei, censura as políticas portuguesas executadas nas colônias africanas. Em sua concepção, apesar de algumas boas medidas do primeiro vice-rei D. Francisco de Almeida, o seu projeto tinha um caráter muito mais mercantilista do que desenvolvimentista.

D. Francisco de Almeida não queria conquista a Índia: queria conquistar o comércio da Índia. As fortalezas teriam o único intuito proteger as feitorias, e as armadas favorecer o negócio. Por isso, também não queria senão aliados nas terras, e por isso se exasperava quando via os seus oficiais andarem às presas e não pensarem em outra coisa. Era no seu entender matar a galinha dos ovos de ouro (CHAGAS, AJVR, [1890] s.d, p.99).

Desse modo, o primeiro governo português inclinava-se mais à proposta de exploração promovida pelo rei D. Manuel e por toda a corte portuguesa. Havia, então, um comportamento generalizado de que “ [...] os que iam à Índia, esses iam procurar pimenta e canela, como o Estado, que lhes dava o exemplo e que se fizera mercador" (CHAGAS, AJVR, [1890] s.d, p. 98).

Com outra concepção, Afonso de Albuquerque implementa um projeto ousado e promissor de ocupação em Gôa. Pinheiro Chagas não esconde a sua predileção por este segundo plano, por acreditar que um país dependente das riquezas coloniais deveria “ [...] fundar um império luso-indiano, [...] tomar posse da terra, colonizá-la, fazê-la uma sucursal de Portugal, como prolongamento da mãe pátria” (IDEM, p.99). Chagas vai mais longe ao considerar que se houvesse tido homens enérgicos e competentes como Afonso de Albuquerque, as outras terras coloniais nunca teriam ficado vulneráveis às invasões do estrangeiro.

Se os outros governadores seguissem o exemplo de Afonso de Albuquerque, teriam feito de Chaul, de Baçaim, de Ceilão, de Cananor e de Cochim o que Afonso de Albuquerque conseguiu fazer em Gôa. E depois? Que viessem holandeses e ingleses. Se eles não consdeguiram arrancar a tradição portuguesa das terras que nos tomaram, também nos não teriam arrancado a bandeira se o sonho de Afonso de Albuquerque houvesse chegado a realizar-se (IDEM, p.100). 
Nesse sentido, Chagas relacionava as perdas coloniais a uma deprimente administração ultramarina, em que dois fatores foram cruciais: o Estado e o soldado se tornarem comerciantes e o fato de os portugueses não saberem honrar as alianças locais.

Ah! Sr. Gaspar Correia, se nos conservássemos sempre assim, não teríamos talvez tanto que fazer nesta Índia. Muitas vezes, é certo, encontramos traição e má vontade, mas ainda mais vezes fomos nós que malquistamos com gente que estava bem disposta conosco. O que é certíssimo, porém, é que o Sr. Vasco da Gama, por boas maneiras, teve do rei de Melinde tudo quanto quis (CHAGAS, $A D I$, [1890] 1898, p. 82).

O caso mais ilustrativo dessa má vontade portuguesa em relação aos nativos, reconstruído no plano ficcional de O naufrágio de Vicente Sodré, é a do capitão-mor Vicente Sodré para com o rei de Cochim. Nesse episódio, mesmo sabendo da fragilidade bélica do aliado, que estava sob ameaça iminente do rei de Calicute, Sodré retira suas esquadras para ir piratear nos mares das ilhas Kuri-Muri. Contudo, a sua usura e cobiça levam-no à morte, ao tentar recuperar um cofre cheio de riquezas.

Era a primeira cena [não proteger o rei de Cochim contra a invasão de Samorim, rei de Calicute] dessa longa série de discórdias vergonhosas, que mancharam e ensanguentaram tantas vezes o nosso governo na Índia. A cobiça aparecia também pela primeira vez, infrene, sôfrega, antepondo-se a todas as condições de patriotismo, de pundonor, de lealdade (CHAGAS, ONVS, [1892] 1910, p. 69).

Mas na produção literárias de 1890-92, Pinheiro Chagas além de evidenciar algumas atuações vergonhosas de personalidades históricas, ele acrescenta à publicação dos romances históricos de terceira fase três contos de caráter apologético. Em A descoberta das Índias. contada por um marinheiro, ele reuniu o conto O baluarte de Diu e, em O naufrágio de Vicente Sodré, outros dois são agregados, o conto A galveta de Antonio Muniz e a novela A passagem do Bojador. Possivelmente, estes textos foram anexados às obras com o intuito de manter um número de páginas necessárias à editoração. Como também eles aparecem como um contrapeso entre as covardias e vilanias de uns e o destemor e o patriotismo de outros, que defenderam os interesses nacionais com a própria vida.

Dessa maneira, estas constantes comparações entre as ações do passado e do presente têm o claro propósito de acordar consciências, fazendo com que o leitor se posicione de maneira crítica no seu tempo. Por isso, é comum deparar-se a todo instante com reflexões 
anacrônicas como, por exemplo, esta que se refere à rivalidade luso-britânica na África oriental.

[...] os espanhóis nesse tempo, como os ingleses agora, andavam à cata de qualquer bocado de terras ultramarinas que nos tivesse escapado ou em que não tivesse bem assente e bem consolidado o nosso direito (CHAGAS, ONVS, [1892] 1910, p.15).

Posto isto, se suas obras não atingiram o rigoroso patamar da genialidade, pelo menos devemos prestar justiça ao fato de na sua ficção não estar ausente o debate sobre a questão nacional. Pinheiro Chagas parece descrever uma comédia da História portuguesa protagonizada principalmente pelo governo incompetente e egoísta dos monarcas da dinastia de Bragança. Sob um tom moralizante e irônico, este autor não deixa de evidenciar, muitas vezes por meio de suas personagens, a aliança luso-britânica, incentivada pela casa bragantina, que consistia num negócio rentável apenas para os ingleses. Já Portugal, este não passava de um país fraco e eternamente dependente desse protetorado.

Por fim, entendemos que Pinheiro Chagas empreendeu um projeto literário de resgate do ser português tanto em compêndios de História como por meio de seus romances históricos sob o formato de um gênero híbrido que mescla elementos dramáticos à ação romanesca com o intuito de entreter, mas acima de tudo (in)formar seus compatriotas em matéria nacional.

Portanto, o que se viu em A descoberta da Índia foi um criativo trabalho com a intromissão da história nacional, colocada na boca de um velho marinheiro, que não cabendo nos moldes do herói romântico, relembrou suas aventuras e desventuras a caminho das Índias. De maneira simples, Bastião vai (des)construindo as histórias dos grandes homens e de seus feitos, que, descritos nos manuais de história, aparecem como verdadeiros semideuses.

Nesses aspectos, Pinheiro Chagas surpreende por ser um contador de histórias que cria outro mais realista e humano, que sente medo e tem fraquezas, diferentemente do que se poderia esperar de um escritor tachado, prioritariamente, como melodramático. 


\section{CONSIDERAÇÕES FINAIS}

Nos capítulos anteriores, procuramos mostrar como a fortuna crítica de Pinheiro Chagas trata a sua obra, principalmente o seu romance histórico. Percebemos que, na maior parte dela, pouca importância se dá às suas publicações. Quando não há verdadeira indiferença ao autor, classificam-no como “[...] um folhetinista de motivos históricos ou pretensamente históricos [...]” (CHAVES, 1979, p. 65). Este comentário de Castelo Branco Chaves (1979) resume quase todo o pensamento crítico que vem recaindo sobre Pinheiro Chagas no decorrer dos tempos: o seu suposto oportunismo literário, com a publicação de obras de temas históricos e o caráter folhetinesco delas. Sobre isso, tais estudos consideram que na obra do referido autor não se constata a existência de um projeto literário definido, pois, sucumbido pela pressão da necessidade, Chagas teria se aproveitado do crescente gosto pela História na época para escrever os seus romances históricos.

Se no corpus literário de Chagas há indícios de uma produção elaborada sob a forte pressão do mercado editorial, com o propósito claro de obter um meio de subsistência, por outro lado, o projeto literário que ele propôs, repensa os problemas nacionais e procura discuti-los à sua maneira. Desse modo, percebemos que há em sua obra, ressalvadas algumas evidentes diferenças, uma significativa aproximação em relação às discussões promovidas pela Geração de 70 no que tange à decadência nacional, o que nos leva a crer que Pinheiro Chagas é erroneamente configurado como um antagonista dos novos. De fato, a maior diferença entre eles teria sido Chagas optar preferencialmente pelo romance histórico para refletir sobre o caso português, enquanto os realistas/naturalistas, por seu turno, elegiam o romance de atualidades.

Nesse propósito, como todo romântico, o autor de A máscara vermelha considerava que o romance histórico poderia auxiliar na formação histórica do público da época, ao passo que divertia e instruía. Mas para isso os cultores do gênero deveriam se atentar para algumas especificidades que não poderiam negligenciar na composição deste tipo de romance, tais como: o princípio de distanciamento temporal, a criação de personagens ficcionais e históricas inseridas num mesmo plano ficcional e a consciência histórica, denunciada, por vezes, pelos anacronismos cometidos pelo autor.

Por outro lado, para uma interpretação mais adequada de qualquer romance histórico, Ana Vasconcelos (2008) adverte que mais importante do que conhecer as fontes às quais o romancista recorre para reconstituir a época evocada é compreender o motivo da escolha do 
período. Ao considerarmos tal afirmação, avaliamos que todos os romances de Chagas na sua fase de experimentação ou na intermediária giram em torno da perda da nacionalidade portuguesa e na ineficiência das administrações régias. Isso porque os períodos de tensão que Chagas escolhe (os episódios da Restauração de 1640; do final do século XVIII e do início do XIX) denunciam que, mesmo diante de catástrofes naturais ou da iminência da invasão do território português por outros países, se houvesse dirigentes capazes de estar à frente da nação, Portugal teria se recuperado dos seus momentos de decadência. Mas, na sua concepção, os reis dessas histórias padeciam não só da má influência dos jesuítas, como não sabiam administrar o erário português, como bem denuncia o narrador em A corte de D. João $V$. Pinheiro Chagas parece aproximar os episódios absurdos da História nacional a uma comédia de costumes, como tenta sutilmente estabelecer na representação do período da Restauração, que deveria ser uma fase de liberdade e progresso para Portugal. No entanto, este acontecimento se revelou num dos períodos mais anárquico, em que a omissão de D. João IV motivou diversas intrigas políticas, culminando na morte de inocentes. Já nos seus romances de maturidade, quando se espera que Chagas trate só das conquistas, de maneira apologética, ele se ocupa de narrar as intrigas, e a cupidez exercida pelos portugueses no período áureo das navegações.

Outra interessante conclusão a que chegamos sobre os livros da terceira fase é que a sua intensa produção nos anos de 1890-92 deve ter sido motivada pelo episódio do Ultimatum inglês. Pinheiro Chagas deixa implícito que as constantes invasões que sofria Portugal, desde o século XVI, apesar da sua dependência econômica em relação às colônias, deviam-se, dentre outros fatores, a uma política ultramarina deficiente, que buscava apenas a exploração. Para ele, quase sempre imediatistas, as ações consistiam, no tempo das descobertas, em conservar o título de senhores dos mares e de investir na construção de fortaleza, como meio de se protegerem das investidas dos inimigos. Estas medidas se revelaram, mais tarde, insuficientes para impedir as invasões de coroas estrangeiras. Nessas bases, por evidenciar durante toda a sua produção literária a discussão da questão colonial de maneira a alertar os equívocos dos monarcas portugueses em relação à aliança luso-britânica, Pinheiro Chagas pode ser incluído no grupo de intelectuais que anteciparam o Ultimatum como uma consequência inevitável.

Mas além de estar atento às questões do seu tempo, Chagas dá mostras de sua pretensão em retratar realisticamente as suas personagens históricas. Um bom exemplo disso é o capítulo intitulado Fraquezas de um grande homem, que faz parte do livro O naufrágio de Vicente Sodré. Neste, o grande navegador é destituído de idealizações, pois "Vasco da Gama 
era homem, e seria ridículo querer supô-lo isento das fraquezas da raça humana” (IDEM, p. 23). Assim, deparamo-nos com um Gama invejoso, que desdenha das qualidades do adversário e, até mesmo, chega a afrontar o rei D. Manuel, por este cogitar preteri-lo a favor de Cabral. Contudo, esta imagem diferente daquela laureada de Vasco da Gama já se pode encontrar, sutilmente elaborada, desde A descoberta da Índia. contada por um marinheiro, em que o capitão-mor é retratado como alguém insensível aos medos dos marinheiros em alto mar e vingativo em relação ao tratamento que ele recebera dos indianos. Como vimos, nada dessas personagens as aproxima das qualidades dos heróis românticos, que - por sua nobreza de caráter e força - são quase comparados como entes sobre-humanos, como se percebe na composição de Gonçalo Mendes da Maia, personagem histórica de A morte do lidador, de Alexandre Herculano. Neste conto, um guerreiro de noventa anos peleja como se estivesse nos tempos da juventude. Tanto assim que a sua agilidade é "semelhante ao vento de Deus [...]” (HERCULANO, s.d, p. 41). Desta forma, quando se espera que Mendes da Maia recue ao perceber que o seu exército está em menor número e que os mouros avançam -, ele prefere morrer lutando a viver feito um covarde. Diferentemente desta personagem herculaniana, Chagas mostra uma desromantização de suas figuras históricas, retirando-lhes o caráter de semideuses e mostrando-as nas suas paixões humanas.

Em linhas gerais, o autor de A joia do vice-rei compreendia que, para se escrever um perfeito romance histórico, além de um estudo consciencioso da época, indispensável tanto ao historiador como ao romancista, era necessário organizar o passado, dramatizando-o nas paixões, nos costumes e na vida doméstica de cada um dos indivíduos da geração pretendida. Portanto, para Pinheiro Chagas, o que importa não é a mera descrição histórica, mas esta reanimada no drama. Nesta abordagem, é preciso uma harmonização entre o ficcional e o factual no romance histórico. Não deve haver nem o excesso do primeiro, pois desvirtuaria a verdade histórica, nem uma excessiva preocupação com o pormenor, que incorreria numa perda de unidade romanesca, o que acabaria por transformar o gênero em um mero manual de História, diferente do propósito do romance, que é tratar das verdades humanas com leveza e argúcia.

A visão do conjunto dos quatorze romances deste autor, agora, possibilita-nos afirmar que a História vai interferindo cada vez mais na composição de seu corpus ficcional. Como se pode constatar, desde as primeiras produções, com a presença da intriga romântica ou as muitas peripécias utilizadas para provocar surpresa e manter o interesse do leitor, como amores impossíveis, crimes passionais, pessoas que professavam para expiar as culpas ou suas desilusões amorosas, vinganças implacáveis, pessoas mascaradas, etc. Contudo, na fórmula de 
romance histórico da sua fase final, denominada de estudo histórico romântico, de certa forma, o autor já no título dado à sua composição confessa a impossibilidade de exclusão de todos esses ingredientes românticos de sua ficção. Por isso, não titubeia em criar um personagem-narrador em A descoberta da Índia. contada por um marinheiro, nem duas passagens de intriga amorosa, mesmo que de reduzida importância, relacionadas a Lourenço e à sua prima e, ainda, entre este e a filha do xeique. O único livro no qual esses elementos estão totalmente ausentes é O naufrágio de Vicente Sodré.

Dos interesses que podem suscitar a releitura dos romances históricos de Pinheiro Chagas, o primeiro deles está no modo como ele constrói a maioria de suas mulheres, quase sempre ardilosas, viris e voluptuosas. Embora o romancista histórico esteja se referindo ao passado, ele tem seus olhos fixos no presente. Nesse sentido, pelo tom moralizante que se inscreve no gênero, ele deseja que o público se reconheça nessas páginas, provocando uma mudança de comportamento, principalmente entre o público feminino, que eram os que mais consumiam os romances. Daí, considerarmos que Chagas aproxima as suas entidades femininas ficcionais à imagem da mulher portuguesa do seu tempo, que se dividia entre os rosários e as futilidades da vida cortesã.

Mencionam-se, ainda, as estratégias da dramaturgia (como a linguagem, os diálogos rápidos e a sucessão de cenas) de que ele se utiliza objetivando maior plasticidade e movimento à cena evocada pelo texto. Ele assim o faz para provocar no leitor a ilusão de um quadro histórico mais aproximado do real. Além disso, salientamos a maneira racional como ele pinta as personalidades históricas nacionais, humanizando-as, artifício notável que comprova que ele não pode ser considerado como um patriota reacionário e conservador, epíteto com que a crítica tentava e ainda tenta ridicularizá-lo.

Logo, dentro deste perfil, Pinheiro Chagas parece fazer parte de um movimento estético que buscou racionalizar a realidade que vivia, estabelecendo um diálogo com a História nacional, mesmo que, em algumas vezes, sob um estilo melodramático. No entanto, seu nome permanece indubitavelmente excluído por algumas de suas posições políticas, propaladas na sua vida e na sua obra, que o distanciaram da Geração de 70. 


\section{REFERÊNCIAS:}

ABREU, Maria Fernanda de. O prefácio de Pinheiro Chagas (1876). In: Cervantes no Romantismo português. Cavaleiros andantes, manuscritos encontrados e gargalhadas moralíssimas. Lisboa: Editorial Estampa, 1994. pp.77-92

AgOSTINHO, José. História da Literatura Portuguesa. Porto: Casa Editora de A. Figueirinhas, 1927 pp.360-388.

AGUIAR, Joaquim Alves de. Espaços da memória. Um estudo sobre Pedro Nava. São Paulo: EDUSP, 1998.

ALENCAR, José de. Iracema, lenda do Ceará. São Paulo: Empresa Gráfica Revista dos Tribunais, [1865] 1948.

Pós-Escrito à segunda edição [outubro de 1870]. In: Iracema. São Paulo: Empresa Gráfica Revista dos Tribunais, 1948, pp.232-258.

ALIGHIERI, Dante. A divina comédia. Trad. José Pedro Xavier Pinheiro. São Paulo: Indústrias Gráficas S.A, 1955.

ALMEIDA, Antonio Ramos. Pinheiro Chagas. In.: Simões, João Gaspar. Perspectiva da Literatura Portuguesa do século XIX. Vol I. Lisboa: Edições Ática, 1947 pp.573-583.

ANTUNES, Luísa Marinho. O romance histórico e José de Alencar. Contribuição para o estudo de lusofonia. Funchal: Centro de Estudos de História do Atlântico - CEHA, 2009.

ARANHA, Brito. Dicionário Bibliográfico Português. Estudos de Inocêncio Francisco da Silva. Tomo 16. Lisboa: Imprensa Nacional, 1893 p.288-297.

ARISTÓTELES. Arte poética. Trad. Antonio Pinto de Carvalho. Rio de Janeiro: Editora Tecnoprint Ltda, s.d.

ASSIS, Machado. O primo Basílio. In: Crítica literária. Rio de Janeiro: W.M. Jackson Inc. Editores, [1878]1938. pp.160-86.

BARATA, José Mattoso. Portugal e a Europa na época moderna. In. TERRAGUINHA, José (Org.). História de Portugal. Bauru, São Paulo: EDUSC. 2000. pp.107-128.

BARBUDA, Pedro Júlio. Literatura Portuguesa. Baia: Estabelecimento dos 2 mundos, 1918. pp.294-295.

BARTHES, Roland. L’ effet de réel. In: Communications. nº11, 1968. pp.84-89.

BASTOS, Alcmeno. Introdução ao romance histórico. Rio de Janeiro: Ed. UERJ, 2007. 
BASTOS, Sousa. Carteira do Artista. Apontamentos para a História do Teatro Português e Brasileiro. Principais Artistas, Escritores Dramáticos e Compositores Estrangeiros. Lisboa: Antiga Casa Bertrand, 1898. pp 413-414.

BENALCANFOR, Visconde de. Pinheiro Chagas - A Guerra Peninsular- As Cruzadas - O Juramento da Duquesa - Os Dramas do Mar. In: Fantasias e Escritores Contemporâneos. Porto: Livraria Internacional de Ernesto Chardron, 1874 pp165-183.

BENJAMIN, Walter. Obras escolhidas: Magia e técnica, arte e política. Vol. I. trad. Sergio Paulo Rouanet. 3a . ed. São Paulo: Brasiliense, 1987.

BERDIAEFF, Nicolas. Un nouveau moyen age. (1927) In.: CHEVALIER, Jean. Dicionário de símbolos. Mitos, sonhos, costumes, gestos, formas, figures, cores, números. Trad. Vera da Costa e Silva et. al. 18 . ed. Rio de Janeiro: José Olympio, 2003. pp. 162-163.

BERRETTINI, Célia. Prefácio In.: A arte Poética. São Paulo: Editora Perspectiva, [16?] 1979.

BITENCOURT, J. Barbosa de. História Comparativa da Literatura Portuguesa. Porto: Livraria Chardron, 1923.

BOCCACCIO, Giovanni. Decamerão. São Paulo: Gráfica Círculo. Nova Cultural, 1996

BOURDIEU, Pierre. O ponto de vista do autor. As regras da arte. Gênese e estrutura do campo literário. Lisboa: Editorial Presença, 1996. pp.246-277

. O poder simbólico. Trad. Fernando Tomaz. DIFEL. Lisboa, 1998.

BRAGA, Teófilo. As Modernas Ideias da Literatura Portugueza .Porto: Casa Editora Lugan \& Genelioux, sucessores, 1892.

História do Teatro Português. Garrett e os Dramas Românticos. Séc. XIX. Porto: Imprensa Portuguesa Editora, 1871.

. O sr. Pinheiro Chagas e o desenvolvimento da literatura portuguesa. In: Os Críticos da história da Literatura Portuguesa. Exame das afirmações dos Srs. Oliveira Martins, Antero de Quental e Pinheiro Chagas. Porto: Imprensa Portuguesa Editora, 1872 pp.41-48.

BRANCO, Camilo Castelo; CASTILHO, Antonio Feliciano de Castilho. Carta de 12.08.1866 In: Correspondência de Camilo Castelo Branco a Antonio de Castilho. Ed. Livros Horizontes III. s.d , p.98. 
BRANCO, Camilo Castelo Luta de gigantes. $1^{\mathrm{a}}$ ed. Porto: Fronteira do Caos Editores Lda, [1865] 2006.

. O judeu. 6 ${ }^{\mathrm{a}}$.edição. Lisboa:Parceria A M Pereira, [1866]1970.

. O olho de Vidro.6 ${ }^{\mathrm{a}}$. edição.Lisboa: Parceria A M Pereira, 1968

. O santo da Montanha. 6a. Edição. Lisboa: Parceria A. M. Pereira Lda.,

1972

BRUNO, Sampaio. O romance histórico. O conto satírico In: A geração nova. Os novelistas. Porto: Livraria Chardron de Lello e Irmão - Editores, [1885] 1984. pp.17-28, 76-92

1906.

. Os modernos publicistas portugueses. Cap. II. Porto: Livraria Chardron,

BUESCU, Helena Carvalhão. Dicionário do Romantismo Literário Português. Lisboa: Editorial Caminho, 1997 p.88-89

. Helena Carvalhão. Manuel Joaquim Pinheiro Chagas. In: Biblos Enciclopédia Verbo das Literturas de Língua Portuguesa. vol. 1. Lisboa/ São Paulo: Editorial Verbo, s.d, p.1111-1114.

CABRAL, Alexandre. Correspondência de Camilo Castelo Branco com Antonio Feliciano de Castilho. Vol.III. Livros Horizonte, 1985. p.70

Dicionário de Camilo Castelo Branco. Lisboa: Editorial Caminho, 1988.

p.178-179.

CANDIDO, Antonio. A personagem de ficção. 2ª ed. São Paulo: Editora Perspectiva, [1968] s.d.

2004.

. Ressonâncias. In.: O albatroz e o chinês. Rio de Janeiro: Ouro sobre Azul,

CARPEAUX, Otto Maria. História da literatura ocidental. Rio de Janeiro: Edições O Cruzeiro, 1987.

CARVALHO, Maria Amália Vaz de Carvalho. Alguns homens do meu tempo. In.: Project Gutemberg. Ebook. Biblioteca Nacional de Portugal, [18?] 2008.

. Mulheres e crianças: notas sobre educação. Porto: Editores Joaquim

Antunes Leitão \& Irmão,1880. 
Pereira, 1906. pp. 119-132

Pinheiro Chagas In: Ao correr do tempo. Lisboa: Parceria Antonio Maria

CASTILHO, Antonio Feliciano de. Crítica literária. In: CHAGAS, Manuel Pinheiro. Poema da mocidade. Seguido do anjo do lar. $2^{\mathrm{a}}$. Ed. Lisboa: Parceria Antonio Maria Pereira, [1865]1901. pp.159-198

Pinheiro Chagas. cap.XXIII. In: Telas Literárias. Vol IV. Lisboa: Empresa da História de Portugal Sociedade Editora, [1872] 1907. pp.11-25.

CHAGAS, Manuel Pinheiro. A conspiração de Pernambuco. 2 ${ }^{\mathrm{a}}$. ed. Lisboa: Livraria enciclopédica Editores Afra \& Comp. [1866] 1870, 238p.

A corte de D. João V. Lisboa: Livraria de A. M. Pereira, [1867], Publicações Quipu, 2002. 174p.

A descoberta da Índia. Contada por um marinheiro. $2^{\text {a }}$ ed.Lisboa:Livraria Editora de Mattos Moreira \& Companhia [1890] 1898. 166p.

221p.

A flor Seca. 2a . ed. Lisboa: Pareceria Antonio Maria Pereira, [1866] 1904.

171p.

A joia do Vice-Rei. Lisboa: Livraria de Antonio Maria Pereira, [1890] s.d, [1879], s.d.174p.

A mantilha de Beatriz. 6a edição. Lisboa: Livraria Progresso Editora,

. A Marquesa das Índias. $1^{\mathrm{a}}$. ed. Lisboa: Editor - Proprietário José Augusto Gaspar de Lemos, Matorca/Lisboa. Adolfo Modesto e Companhia Impressores. 1890.248p.

A máscara vermelha. São Paulo: Editora Saraiva, s.d [1873] s.d. 207p.

A virgem Guaraciaba. Lisboa: Empresa Lusitana Editora, Rio de Janeiro: Livraria Editora Jacinto Silva, s.d [1866].

M. Pereira, 1890.

. As colônias portuguesas no século XIX (1811-1890). Lisboa: Livraria de A.

. As duas flores de sangue. Porto: Livraria Civilização Editora. [1875] 1984

Dicionário popular histórico, geográfico, mitológico, biográfico, artístico, bibliográfico e literário. Lisboa: Tipografia do diário ilustrado. Vol. VI, [1878] 1880. 
. Ensaios críticos. Porto: Em Casa da Viúva More, [1866] s.d.

. História alegre de Portugal. 4a. ed. Lisboa: Empresa Literária Universal, 1888.

. Julieta. Lisboa: Edições Rolim, 1985.

. Novos ensaios críticos. Porto: Em Casa da Viúva More Editora, 1867.

. O juramento da Duquesa. São Paulo: Editora Saraiva, [1873], s.d. 205p.

. O Major Napoleão. Lisboa: Livraria de Campos Júnior - Editor. [1867]

s.d.

O naufrágio de Vicente Sodré. $2^{\text {a }}$. ed. Lisboa: Pareceria de Antonio Maria Pereira - Editor. [1892] 1910. 231p.

$245 p$.

. O segredo da Viscondessa. Lisboa: Lallemant Frères Tipografia, 1871.

222p.

. O terremoto de Lisboa: Lisboa: Livraria Editora de Matos Moreira, 1874.

Empresa, [1872] 1874. 288p.

S. Afra \& Companhia, s.d.

Os jesuítas de hoje. In: Vermelhos, Brancos e Azuis. Lisboa: Editores - C.

. Portugal contemporâneo avaliado por um viajante francês In.: Imagens da França e modelos literários franceses n’O Panorama. Universidade Nova Lisboa. pp.1-5. Disponível em: http://ler.letras.up.pt/uploads/ficheiros/4385.pdf em 01.01.2011

Portugueses ilustres. 2a . ed. Lisboa: Livraria de A. Ferin, 1873.

Prólogo. In: LOBATO, Gervásio. A comédia de Lisboa. 2ª . edição. Porto: Livraria Chardron, 1911. p.V-XXV

1973.149p.

Tristezas à beira-mar. Rio de Janeiro: Gráfica Editora Primor, [1866] 
. Um enredo a Calderón. In.: O naufrágio de Vicente Sodré. 2ª ed. Lisboa:

Pareceria de Antonio Maria Pereira - Editor. [1890] 1910. 231p.

Vermelhos, brancos e azuis. Lisboa: Parceria Antonio Maria Pereira, s.d.

CHAGAS, Manuel Pinheiro; MACHADO, Júlio César. Fora da terra. Porto: Livraria Chardron, Braga: Eugênio Chardron, 1878.

CHAVES, Castelo Branco. O romance histórico no Romantismo português. Lisboa. Instituto de Cultura Portuguesa, 1979.

COELHO, Jacinto do Prado. Dicionário de literatura. Literatura brasileira, literatura portuguesa, literatura galega. Estilística literária. Vol I. A.M. Rio de Janeiro: GB. Companhia Brasileira de Publicações, 1969.

Casa da Moeda, 1983.

Introdução ao Estudo da Novela Camiliana. [Lisboa]: Imprensa Nacional -

COELHO, Maria Teresa Pinto. Apocalipse e Regeneração. O ultimatum e a mitologia da pátria na literatura finissecular.1 ${ }^{\text {a }}$ ed. Lisboa: Edições Cosmos, 1996.

COMPAGNON, Antoine. O trabalho de citação. Trad. Cleonice P. B. Mourão. Belo Horizonte: Editora UFMG, 1996.

CORDEIRO, Luciano. Livro de crítica. Arte e literatura portuguesa de hoje. 1868-1869. Porto: Tipografia Lusitana Editora,1869. pp.234-235.

Segundo livro de críticas. Arte e literatura de hoje. Porto: Tipografia Lusitana Editora, 1871. pp.7.

CORREIA, Gaspar. Lendas da Índia. Notas de Rodrigo José de Lima Felner. Tomo I. Lisboa: Tipografia da Academia Real das Ciências, 1858. 530 p.

COSTA, João. Castilho e Camilo. Correspondência trocada entre os dois escritores. Coimbra: Imprensa da Universidade, 1925.

DESPRÉAUX, Nicolas Boileau. A arte poética. São Paulo: Editora Perspectiva, [16?] 1979.

DIAS, Simões J. História da literatura portuguesa. 12 ed. Lisboa: Livraria Clássica Editora de A.M. Teixeira \& C. ( Filhos), 1929. p. 271. 
DOLEZEL, Lubomír. Mimesis and possible worlds (1988) In: PUGA, Miguel Rogério. $O$ essencial sobre o romance histórico. Lisboa: Imprensa Nacional-casa da moeda, 2006.

ELIAS, Neide. A tradução do discurso popular feminino em Lorca. In.: DINIZ, Alai Garcia (Org.). Hispanismo 2004. 3a .ed. Florianópolis: UFSC, 2006. p.329-338

ESTEVES, Antonio R.; MILTON, Heloísa Costa. Narrativas de extração histórica. In.: CARLOS, Ana Maria et. al. (Orgs.). Ficção e história. Leituras de romances contemporâneos. Assis: UNESP, 2007, pp.12-42.

FELNER, Rodrigo. Nota preliminar, Lendas das Índias. Lisboa: 1858. pp. I - XIII.

FERREIRA, Alberto. Bom senso e bom gosto. Questão coimbrã. Textos Integrais da polêmica; recolha, notas e biobibliografia por Maria José Marinho, 4 vols, Lisboa: Portugália Editora, 1966-1970.

FERRERAS, Juan Ignácio. Benito Pérez Gáldos y la invención de la novela histórica nacional. Madrid: Endymion, 1997. 203p.

FIGUEIREDO, Cândido. Homens e letras. Galeria de poetas contemporâneos. Lisboa: Tipografia Universal, 1881. pp. 77 e 385.

FIGUEIREDO, Fidelino de. Literatura portuguesa. Desenvolvimento histórico as origens à atualidade. Rio de Janeiro: Editora à Noite, s.d.

de Literatura, s.d.

Shakespeare e Garrett. São Paulo: Conselho Estdual de Cultural Comissão

FOLEY, Barbara. Telling the truth. The theory and practice of coumentary fiction. Ithaca and London: Cornell Universitu Press, 1986

FOUCAULT, Michel. O que é um autor? In: Ditos e escritos III. Estética. Literatura, Pintura e Música. Rio de Janeiro: Forense Universitária, 2006. pp.264-298.

GAIO, Silva. Mário. Episódios das lutas civis portuguesas de 1820-1834. Introd. Joaquim Ferreira. Porto: Porto Editora, Lda. [1867] 1984.

GAMA, Arnaldo. A última dona de São Nicolau. Porto: Livraria Simões Lopes, [1864]1950. O segredo do Abade. 2a . ed. Porto: Livraria Simões Lopes, [1864]1951. 
GARRETT, Almeida. O arco de Sant'Ana. In.: Obras Completas de Almeida Garrett. vol I.Porto: Lello \& Irmão Editores, [1850] 1966.

Grande enciclopédia portuguesa e brasileira. Vol XXI. Lisboa/Rio de janeiro: Editorial Enciclopédia Ltda., 1945. pp.751-754.

GUINSBURG, Jaco. Romantismo, historicismo e história. In: O Romantismo. São Paulo: Perspectiva, 1978. pp.13-21.

GUSDORF, Georges. Lés écritures du moi. In.: AGUIAR, Joaquim Alves de. Espaços da memória. Um estudo sobre Pedro Nava. São Paulo: EDUSP, 1998.

HAMBURGER, Käte. A lógica da criação literária. Trad. Margor P. Malnic. São Paulo: Perspectiva, 1975.

HEGEL. Estética: Poesia. Trad. Álvaro Ribeiro. Lisboa: Guimarães Editores, [18?]1964.

HERCULANO, Alexandre. A Velhice. In.: O Panorama, n¹70, 1 de Agosto de 1840, p. 243.

Ática Ltda., s.d A morte do Lidador. In.: Contos históricos portugueses. São Paulo: Editora

HESS, Rainer Os inícios da lírica moderna em Portugal. Trad. Maria Antonio Horster e Renato Correia. Imprensa Nacional, 1978.

HUGO, Victor. O corcunda de Notre-Dame. Rio de Janeiro: Editora Três, [1831]1973.

HUTCHEON, Linda. Poética do pós-modernismo. História, teoria, Ficção. Trad. Ricardo Cruz. RJ: Imago Ed., 1991.

INDURÁIN, Carlos Mata. Estrutucturas e tecnicas narrativas de la novela histórica romántica espanhola. In: SPANG, Kurt . La novela histórica. Teorias e comentários. $2^{\mathrm{a}}$.ed. Navarra: Ediciones Universidad de Navarra, S.A (EUNSA), 1998.

JÚDICE, Nuno. Prefácio. In: CHAGAS, Manuel Pinheiro. Julieta. Lisboa: Edições Rolim, 1985.

KERMODE, Frank. In: Revista colóquio letras. Nrs. 147/148. Jan- jun de 1998. Lisboa: S/ editora.

LEITE, Ligia Moraes Chiappini. O foco narrativo. ou a polêmica em torno da ilusão.10a ed. São Paulo: Ed. Ática, 2001. 
LIMA, Luiz Costa. De que são feitos os tijolos da história? In: O controle do Imaginário. Razão e imaginário nos tempos modernos. $2^{\mathrm{a}}$. ed. Rio de Janeiro: Forense Universitária, s.d.

LINS, Álvaro. História da literatura de Eça de Queirós. Rio de Janeiro: Livraria José Olímpio Editora, 1939.

LISBOA, Eugênio. (coordenação). Dicionário cronológico de autores portugueses. Vol. II. Lisboa: Publicações Europa-América, s.d. pp.239-241.

LOBATO, Gervásio. Crônica Moderna. In: Revista Crítica Ilustrada. Lisboa: Oficina Tipográfica da Empresa Literária de Lisboa, 1881 pp.281-285.

LOPES, Maria Antonia. Mulheres, espaço e sociabilidade. A transformação dos papeis femininos em Portugal à luz de fontes literárias (segunda metade do século XVIII). Lisboa: Livros Horizonte, 1989.

LOURENÇO, Eduardo. O labirinto da saudade. Psicanálise mítica do destino português. Lisboa: Publicações Dom Quixote, 1982.

LUKÁCS, György. A teoria do romance. Trad. José Marcos Mariani de Macedo. São Paulo: Duas Cidades. Ed. 34, 2000. . O romance histórico. Trad. Rubens Enderle. São Paulo: Boitempo, 2011.

MACHADO, Álvaro Manuel. Dicionário de literatura portuguesa. Lisboa: Editorial Presença, 1996.

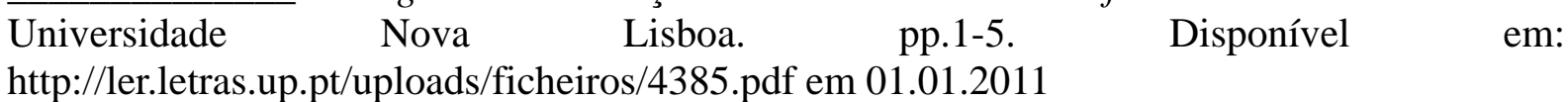
$\begin{array}{rrrrr}\text { - Imagens da França e modelos literários franceses n’O } & \text { Panorama. } \\ \text { Nova } & \text { Lisboar } & \text { pp.1-5. } & \text { Disponível } & \text { em: }\end{array}$ http://ler.letras.up.pt/uploads/ficheiros/4385.pdf em 01.01.2011

MACHADO, Júlio César. Prefácio. In.: Fora da terra. Porto: Livraria Chardron, Braga: Eugênio Chardron, 1878. pp.V-LII

MANZONI, Alessandro. Os noivos. $3^{\mathrm{a}}$. ed. Trad. José Dentinho. Lisboa: Editorial Inquérito. 1850.

MARINHO, Maria de Fátima de. D. Sebastião e o romance histórico. In.: Revista da Faculdade de Letras. Línguas e Literaturas. Porto. 2002, pp.365-386

S.A., 1999. O romance histórico em Portugal. Porto: Campo das letras - Editores, 
Campo das letras - Editores, S.A., 2005.

Padres e Frades: de malditos a corruptos. Revista da Faculdade de

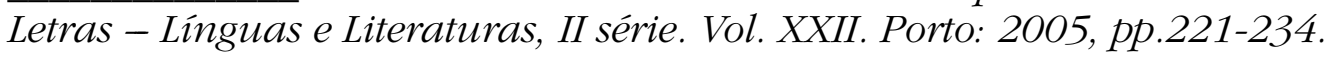

MARTÍNEZ, Pilar Nicólas. A mantilha de beatriz: una adaptación portuguesa de la comedia calderoniana. Península. Revista de Estudos Ibéricos, nº 4 - ano 2007. pp.347-370

MARTINS, Oliveira. Portugal Contemporâneo. Vol II. Porto: Artes Gráficas, [1881]1951.

MATOS, A. Campos. Dicionário de Eça de Queirós. 2 ed. Lisboa: Editorial Caminho, 1988. pp.711-715.

Polêmica. Eça de Queirós - Pinheiro Chagas. "Brasil e Portugal".

Lisboa: Parceria Antonio Maria Pereira, 2001.

MATOS, Sérgio Campos. Historiografia e memória nacional no Portugal do século XIX. (1846-1898). Lisboa: Edições Colibri, 1998. pp.37-39.

McHALE, Brian. Postmodernist Fiction. 1ª . ed. London and New York: Routledge, 1987.

MEDINA, João. Eça, Antero e Victor Hugo. Estudos sobre a cultura portuguesa do século XIX. Oficinas Gráficas de Barbosa \& Xavier Lda: Lisboa, 2001.

. Pinheiro Chagas, A virgem vermelha e a bengala do anarquista. In: Seara nova, $\mathrm{n}^{\mathrm{0}}$ 1539/1540. Propriedade e Editora: Empresa de Publicidade, janeiro/fevereiro de 1974. p.17-21, p.26-30.

MELO, Francisco Manuel. O fidalgo aprendiz. 4ª edição. Lisboa: Livraria Clássica Editora, s.d.

MELO, Gladstone Chaves de. Alencar e a língua brasileira. Seguida de Alencar, cultor e artífice da língua. $3^{\text {a }}$. Ed. Rio de Janeiro: Conselho Federal de Cultura, 1972.

MOISÉS, Massaud. Dicionário de termos literários. 12ª ed. São Paulo: Cultrix, 2004.

MINDLIN, Dulce Maria Viana. José de Anchieta: no limiar da Santidade. Goiânia: Kelps, 1997.

MONTEIRO, Mário. Pinheiro Chagas. Patriota e Amigo do Brasil. Rio de Janeiro: Editora Livraria Francisco Alves, 1943. pp.11-66. 
MOOG, Vianna. Eça de Queiroz e o século XIX. Porto Alegre: Edição da Livraria do Globo, 1938. p.23.

NUNES, Sílvia Alexim. O século XVIII e a construção da imagem materna. In.: O corpo do diabo entre a cruz e a caldeirinha. Um estudo sobre a mulher, o masoquismo e a feminilidade. Rio de Janeiro: Civilização Brasileira, 2000.

OLIVEIRA, Antonio Corrêa de A. Texto estabelecido e introdução e notas. In: MELO, Francisco Manuel. O fidalgo aprendiz. 4ª . edição. Lisboa: Livraria Clássica Editora, s.d, p.734.

OLIVEIRA, Aurélio. A viagem do Gama nas crônicas do reino. Porto: Faculdade de Letras do Porto, 1998.

ORTIGÃO, Ramalho. Correio de hoje. (1870-1871) Tomo II. Lisboa: Livraria Clássica Editora A. M. Teixeira e C ${ }^{a}$ (Filhos), [1871] 1948.

Editora, 1970.

As farpas. In.: Obras completas. Tomo VIII. Lisboa: Livraria Clássica

PASSOS, Carlos de. Prefácio. In: A última dona de S. Nicolau. Porto: Livraria Simões Lopes, 1950.

PELAYO, Marcelino Menéndez. El drama histórico. (1942) In: SPANG, Kurt . Apuntes para la definición y el comentário del drama. In: SPANG, Kurt (Org.) El drama histórico. Teoría y comentários. Navarra: Ediciones Universidad de Navarra, S.A (EUNSA), 1998.pp12-13.

PELOGGIO, Marcelo. José de Alencar e as visões de Brasil. 2006. 233f. Tese (Doutorado)Instituto de Letras, Universidade Federal Fluminense, 2006.

PESAVENTO, Sandra J. (org.). Leituras cruzadas. Diálogos da história com a literatura. Porto Alegre: Ed. Universidade/UFRGS, 2000.

PICOCHE, Jean Louis. Um romântico español: Enrique Gil y Carrasco (1815-1846). In.: INDURÁIN, Carlos Mata. Estrutucturas e tecnicas narrativas de la novela histórica romántica espanhola. La novela histórica. Teorias e comentários. 2ª .ed. Navarra: Ediciones Universidad de Navarra, S.A (EUNSA), 1998.

PINTO, Silva. Balzac em Portugal. Cap. XII. In: Controvérsias e Estudos Literários. Porto: Imprensa Comercial de Santos Correia e Mathias, 1878 pp.143-155.

PIRES, Antonio Machado. A ideia de decadência da Geração de 70. Lisboa: Veja, 1992. 
PRIETO, Célia Fernández. História y novela: Poética de la novela histórica. 2a . ed. Pamplona: Ediciones Universidad de Navarra S.A, 2003.

PUGA, Miguel Rogério. O essencial sobre o romance histórico. Lisboa: Imprensa Nacionalcasa da moeda, 2006.

QUEIRÓS, Eça de. As meninas da geração nova em Lisboa e a educação contemporânea. In.: Uma campanha alegre. 6a. ed. Porto: Lello \& Irmão Editores, 1946. pp.105-132

2009. . O crime do padre Amaro. $3^{\mathrm{a}}$. ed. Lisboa: Publicações Europa América, . O primo Basílio. São Paulo: Ática, 1979.

QUENTAL, Antero de. Prosas. Vol II. Coimbra: Imprensa da Universidade, [1872] 1926. pp.235-240.

REBELLO, Luis Francisco. Teatro Português. 120 anos de Literatura Teatral Portuguesa. Uma Antologia. Lisboa: Círculo do Livro Lda., 1968. pp.25.

REIS, Carlos; LOPES, Ana Cristina M. Dicionário de Narratologia. $6^{a}$. ed. Coimbra: Livraria Almedina, 2007.

REIS, Carlos. História da Literatura Portuguesa. Vol. 5. Lisboa: Publicações Alfa, 2001.

REIS, Carlos; PIRES, Maria da Natividade. História da literatura portuguesa. O Romantismo. Vol. V. 2ª Edição. Lisboa/São Paulo: Editorial Verbo, 1999.

RÉMEDIOS, Mendes dos. História da literatura portuguesa desde as origens até a atualidade. Coimbra: Atlântida Livraria Editora, 1930.

RIBEIRO, José Antonio Pereira. O romance histórico na literatura brasileira. São Paulo: Secretaria da Cultura, Ciência e Tecnologia, Conselho Estadual de Cultura, 1976.

RIBEIRO, Maria Aparecida. O saí e a serpente: diálogos entre José de Alencar e Pinheiro Chagas. In: Ver. De letras- N²9(2)- vol.1-jan/jul., 2009.

ROGER, Jérôme. A crítica literária. Trad. Rejane Janowitzer. Rio de Janeiro: DIFEL, 2002.

SANTILI, Maria Aparecida. Nota preliminar. In: BRANCO, Camilo Castelo. O santo da montanha. 6a. Edição. Lisboa: Parceria A. M. Pereira Lda., [1866] 1972, p.I-XIX. 
SARAIVA, Antonio José. Lopes, Oscar. História da literatura portuguesa. 10 ed. Porto: Editora Ltda., 1966.

SAYERS, Raymond S. Onze estudos de literatura brasileira. Tradução e Roberto Raposo. Rio de Janeiro: Civilização Brasileira; [Brasília]: INL, 1983.

SCOTT, Walter. Ivanhoé. London: Everyman’s Library. [1819]1917 . The fortunes of nigel. Prefácio (1822). The Project Gutemberg Ebook. S.l.

s.d

Waverley. Or tis sixty years since. Prefácio. S.l.: A Penn State Electronic Classics Publication Series, [1814] s.d.

SÉRGIO, Antonio. Breve interpretação da história de Portugal. Lisboa: Livraria Sá da Costa Editora, 1978.

SERRA, José Correia. Discurso Preliminar. Academia. Tomo I, [1790], p. VII- XI. In: VASCONCELOS, Ana Isabel. O tratamento da História no drama romântico português. Limite. $\mathrm{N}^{\mathrm{o}}$ 2. 2008, pp.79-95

SERRÃO, Joel. Dicionário de História de Portugal. Porto: Livraria Figueirinhas, 1992.

SHAW, Harry. The forms of the historical fiction: Sir Walter Scorr and his sucesors. Ithaca and London: Cornell University Press, 1983.

SILVA, Innocêncio Francisco da. Introdução. In.: CHAGAS, Manuel Pinheiro. Os guerrilheiros da morte. Lisboa: Escritório da Empresa. 1872. pp. XVII-XXXIX

. Joaquim Pinheiro das Chagas. In: Dicionário dele Tomo XII, 1872.

SIMÕES, Guilherme Augusto. Dicionário de Expressões populares portuguesas. Arcaísmos, regionalismos, calão e gíria, ditos, frases feitas, lugares comuns, aportuguesamentos, estrangeirismos e curiosidades da linguagem. Lisboa: Perspectiva e realidades, 1984.

SIMÕES, João Gaspar. A Geração de 70. Alguns Tópicos para a sua história. Lisboa: Editorial Inquérito Limitada, [194?] s.d

- Perspectiva histórica da ficção portuguesa das origens do século XX. Lisboa: Dom Quixote, 1987. p.422

SOUSA, Maria Leonor Machado de. A literatura negra ou de terror em Portugal. séculos XVIII e XIX. Lisboa: Publicações D. Quixote, 1987. 
Moeda, 1981.

. Um estudo. In.: Paulo, o montanhês. Lisboa: Imprensa Nacional. Casa da

SPANG, Kurt . Apuntes para la definición y el comentário del drama. In: SPANG, Kurt (Org.) El drama histórico. Teoría y comentários. Navarra: Ediciones Universidad de Navarra, S.A (EUNSA), 1998

SPANG, Kurt; ARELLANO, Ignácio; MATA, Carlos. La novela histórica. Teoria y comentários. 2ª ed. Pamplona: Ediciones Universidad de Navarra, S.A, 1998.

STAIGER, Emil. Conceitos fundamentais da poética. Rio de Janeiro: Tempo Brasileiro, 1972.

THIBAUDET, Albert. Phylosiologie de la critique In: ROGER, Jérôme. A crítica literária. Trad. Rejane Janowitzer. Rio de Janeiro: DIFEL, 2002.

TORGAL, Luís Reis. Ideologia política e teoria do Estado na Restauração. Vol. I. Coimbra: Biblioteca Geral da Universidade de Coimbra, 1981.

TURNER, Joseph W. The kinds of historical fiction: an essay in definition and methodology. In: Genre XXII. Oklahoma: University of Oklahoma, 1979. pp.333-355.

UBERSFELD, Anne. El diálogo teatral. Tradução de Arminda Maria Córdobra. Buenos Aires: Galerna, 2004.

Le drame romantique. Paris: Éditions Belin. 2008.

VASCONCELOS, Ana Isabel Teixeira de. O drama histórico português do século XIX (18361856). Lisboa: Fundação Calouste Gulbenkian, 2003

Ana Isabel Teixeira de. O tratamento da história no drama romântico português. In.: Limite. $\mathrm{n}^{0}$ 2. Universidade Aberta. 2008. pp 79-95

VELOSO, J. A. G. A (de) formação da imagem: Pinheiro Chagas refletido pelo monóculo de Eça de Queirós. 2007. 161 f. Dissertação (Mestrado) _ Faculdade de Filosofia, Letras e Ciências Humanas, Universidade de São Paulo, São Paulo, 2007.

VENTURA, Roberto. Estilo tropical: História cultural e polêmicas literárias no Brasil, 18701914. São Paulo: Companhia das Letras, 1991.

VIEIRA, Nelson H. Brasil e Portugal. A imagem recíproca. O mito e a realidade na expressão literária. Lisboa: Instituto de Cultura e Língua Portuguesa, 1991 
VIGNY, Alfred. Cinq mars. Paris: Michel Lévy Frères Editeurs, [1827] 1869.

VÓLARO, Carlos Henrique. Notas sobre os papéis em torno da execução de Francisco de Lucena, secretário de Estado de D. João IV. s.d. pp.1-14

WHITE, Hayden. Meta-história: a imaginação histórica do século XIX. São Paulo: Editora da Universidade de São Paulo, 2008. 
ANEXOS 


\begin{tabular}{|c|c|c|c|c|}
\hline \multicolumn{5}{|c|}{ QUADRO DA PRODUÇÃO LITERÁRIA DE MANUEL JOAQUIM PINHEIRO CHAGAS (1842-1895) ${ }^{159}$} \\
\hline 1864 & 1865 & 1866 & 1867 & 1868 \\
\hline $\begin{array}{l}\text { *Esboço Biográfico de Henrique } \\
\text { Luiz Feijó da Costa } \\
\text { * A San Felice, de Alexandre } \\
\text { Dumas (romance/tradução) } \\
\text { * Nàdege, de Luiz Enaúlt } \\
\text { (romance/tradução) } \\
\text { * Um drama da regência, de Paul } \\
\text { Féval (romance/tradução) }\end{array}$ & $\begin{array}{l}\text { * Poema da mocidade (poesia) } \\
\text { * Anjo do lar (poesia em } \\
\text { homenagem à sua esposa publicada } \\
\text { em folhetins em } 1863 \text { ) }\end{array}$ & $\begin{array}{l}\text { * Opúsculos da Questão Bom senso e } \\
\text { Bom gosto } \\
\text { * Contos e descrições ( Uma página da } \\
\text { vida de Elesbão Mota; Amor fatal; } \\
\text { Semana Santa em Lisboa) } \\
\text { * Agonias obscuras (Brinde no Diário } \\
\text { de Notícias) } \\
\text { * Ensaios críticos (CL) } \\
\text { *A virgem Guaraciaba (RH) } \\
\text { *A conspiração de Pernambuco (RH)- } \\
\text { continuação de A virgem Guaraciaba } \\
\text { * Tristezas à beira-mar (RC) } \\
\text { * A flor seca (R) }\end{array}$ & $\begin{array}{l}\text { * A Corte de D. João V }(\mathrm{RH}) \\
* \text { Cenas e fantasias portuguesas } \\
* \text { Novos ensaios críticos (CL) } \\
\text { * Estudo biográfico de J. E. } \\
\text { Carvalho Montenegro } \\
\text { * O conde de Camors, de Octavio } \\
\text { Feuillet (romane/tradução) }\end{array}$ & $\begin{array}{l}\text { * A família de Pemarvan, de Júlio de } \\
\text { Sandeau (romance/traução) }\end{array}$ \\
\hline 1869 & 1870 & 1871 & 1872 & 1873 \\
\hline $\begin{array}{l}\text { * Portugueses ilustres (coletânea de } \\
\text { biografias) } \\
\text { * Novelas histórias ( O wali de } \\
\text { Santarém; O escudeiro de Nuno } \\
\text { Álvares; A passagem do Bojador; O } \\
\text { berço da maldição; Uma aventura } \\
\text { de capa e espada; A noiva do } \\
\text { cadafalso) } \\
\text { * A Morgadinha Valflor (teatro) } \\
\text { * O selo vermelho, de A. de Vigny } \\
\text { (romance/tradução) } \\
\text { * O pára-raios, de Ch. de Bernard } \\
\text { (romance/tradução) } \\
\text { *O álbum do regimento, de E. } \\
\text { About (romance/tradução) } \\
\text { * A judia (teatro - } 5 \text { atos) }\end{array}$ & $\begin{array}{l}\text { * Ministros, padres e Reis } \\
\text { * As venturas da riqueza, de Henri } \\
\text { Conscience (romance/tradução) } \\
\text { * Flor de Lis, de Octavio Feuillet } \\
\text { (romance/tradução) }\end{array}$ & $\begin{array}{l}\text { * História da revolução da comuna de } \\
\text { Paris. Vol I e II (História) } \\
\text { * História da guerra entre a França e a } \\
\text { Prússia (História) } \\
\text { * Durante o combate } \\
\text { * O testamento do Conde, de Frederico } \\
\text { Soulié (romance/tradução) } \\
\text { * A fada de Auteil, de Ponson Du } \\
\text { Terrail (romance/tradução) }\end{array}$ & $\begin{array}{l}\text { * Desenvolvimento da literatura } \\
\text { portuguesa (tese para concurso) } \\
\text { * O segredo da Viscondessa }(\mathrm{R}) \\
\text { * Guerrilheiros da morte }(\mathrm{RH}) \\
\text { * Madrid, cenas de viagem } \\
\text { * A gravata branca, de E. Gondinet } \\
\text { (teatro/tradução) } \\
\text { * O major Napoleão }{ }^{162}(\mathrm{RH}) \\
\text { * O filho de Marat, de Alexandre } \\
\text { Dumas (romance/tradução) }\end{array}$ & $\begin{array}{l}\text { * Amigas e pecadoras } \\
\text { * A máscara vermelha (ROH) } \\
\text { * O juramento da Duquesa (ROH) - } \\
\text { continuação de A máscara vermelha } \\
\text { * Astúcias de namorada } \\
\text { * Um melodrama em Santo Thyrso } \\
\text { * Regina, episódio das Confidências, de A. } \\
\text { de Lamartine (romance/tradução) } \\
\text { * A vingança do Sargento, de La Landelle } \\
\text { (romance/tradução) } \\
\text { * Vermelhos, brancos e azuis (crônicas } \\
\text { organizadas, que o autor publicara em } \\
\text { vários jornais) }\end{array}$ \\
\hline
\end{tabular}

${ }^{159}$ Preservamos a denominação dada pelo autor nas páginas que antecedem cada obra: RH - Romance Histórico; ROH - Romance Original Histórico; RC - Romance contemporâneo; R - Romance; RNO - Romance Nacional Original; CL - Crítica Literária.

${ }^{160}$ Algumas dessas novelas saíram antes no Arquivo Pitoresco.

${ }^{161}$ Pretexto num ato para a Marselheza Final, com uma introdução em resposta ao prólogo de O gladiador, de Latino Coelho.

${ }^{162}$ Incluído, neste romance, o conto fantástico A feiticeira de Smolenko, publicado anteriormente em folhetim, por meio da técnica narrativa mise en abyme. 


\begin{tabular}{|c|c|c|c|c|}
\hline 1874 & 1875 & 1876 & 1877 & 1878 \\
\hline $\begin{array}{l}\text { * A liberdade (poesia) } \\
\text { * O terremoto de Lisboa (RH/RNO) } \\
\text { * Educação Popular }{ }^{163}(14 \text { vols.) } \\
\text { * As grandes verdades religiosas, de } \\
\text { Baronesa de Mackau (tradução) } \\
\text { * Memórias de Paulo de Kock, de E. } \\
\text { Bellami (romance/tradução) } \\
\text { * O casamento de Frei Serapião, de H. } \\
\text { de La Madeleine (romance/tradição) } \\
\text { * A oração da tarde, de Marianno de } \\
\text { Larra (teatro/tradução) } \\
\text { *Os tribunais secretos, de Paul Féval } \\
\text { (romance/tradução) } \\
\text { * Janto com minha mãe, de Thédore } \\
\text { Barrière (teatro/tradução) }\end{array}$ & $\begin{array}{l}\text { * As duas flores de Sangue (RH) } \\
\text { * Madalena e Helena (teatro) } \\
\text { * Quem Desdenha ... (teatro) } \\
\text { * O drama do povo (teatro) } \\
\text { * Fisiologia das escolas, de } \\
\text { Madame C. Bray (tradução) }\end{array}$ & $\begin{array}{l}\text { * Chuva e bom tempo } \\
\text { * Prólogo na tradução de D. Quixote } \\
\text { de La Mancha (CL) } \\
\text { *Infâncias célebres, de Madame L. } \\
\text { Colet (romance/tradução) } \\
\text { *Casamentos fidalgos, de Octavio } \\
\text { Feuillet (romance/tradução) } \\
\text { * Castelo Branco, de Octavio Feuillet } \\
\text { (teatro/tradução) } \\
\text { * O caso de consciência, de Octavio } \\
\text { Feuillet (teatro/tradução) } \\
\text { * Partidas das damas, de Octavio } \\
\text { Feuillet (teatro/tradução) }\end{array}$ & & $\begin{array}{l}\text { * A mantilha de Beatriz (RO) } \\
\text { * A propriedade literária, carta ao } \\
\text { Imperador do Brasil } \\
\text { * Fora da terra (crônicas escritas em } \\
\text { parceria com Júlio César Machado, } \\
\text { depois da morte deste autor). } \\
\text { * A roca de Hércules (teatro) } \\
\text { * A primeira missa no Brasil, de Victor } \\
\text { Meireles (Análise oliográfica) } \\
\text { *O capitão Paulo, de Alexandre } \\
\text { Dumas (romance/tradução) } \\
\text { * Os amores de Felipe, de Octavio } \\
\text { Feuillet (romance/tradução) } \\
\text { * Prólogo da Comédia de Lisboa, de } \\
\text { Gervásio Lobato (estudo sobre } \\
\text { realismo, romantismo e humorismo) } \\
\text { Prefácio no livro Carteira de um } \\
\text { viajante: apontamentos a lápis de } \\
\text { Carlos Lobo D’Avila }\end{array}$ \\
\hline 1879 & 1880 & 1881 & 1882 & 1883 \\
\hline $\begin{array}{l}\text { * Brasileiros Ilustres (coletânea de } \\
\text { biografias) }\end{array}$ & $\begin{array}{l}\text { * História alegre de Portugal } \\
\text { (História) } \\
\text { *Resumo da História de Portugal } \\
\text { (História) } \\
\text { * O descobrimento do Brasil } \\
\text { (História) } \\
\text { * O centenário de Luis de Camões } \\
\text { (Estudo biobliográfico) }\end{array}$ & $\begin{array}{l}\text { * Uma canção romântica (Brinde no } \\
\text { Diário de Notícias) }\end{array}$ & * Origens do teatro latino & \\
\hline
\end{tabular}

${ }^{163}$ Fazem parte desta coleção os livros: A história dos povos antigos do oriente; Aljubarrota; os dramas célebres do amor; História do corpo humano; A guerra do Paraguai; Vida de Jesus; Vulcões e tremores de terra; Os dramas do mar; As cruzadas; A guerra peninsular; O último rei cavaleiro; Marquês de Pombal; Conquista do Peru e A guerra da Restauração. 


\begin{tabular}{|c|c|c|c|c|}
\hline 1885 & 1886 & 1887 & 1888 & 1889 \\
\hline * A guerra da independência & & $\begin{array}{l}\text { * As descobertas de Juca: A terra e o } \\
\text { mar, de Emílio Desbeaux } \\
\text { (romance/tradução) }\end{array}$ & $\begin{array}{l}\text { * Marrocos e Constantinopla, de } \\
\text { Edmund d’ Amicis (outros/tradução) } \\
\text { * O abade Constantino, de L. } \\
\text { Havély (romance/tradução) }\end{array}$ & $\begin{array}{l}\text { * A vida do general Osório } \\
\text { * O Dr. Rameau, de Jorge Ohnet } \\
\text { (romance/traução) } \\
\text { * A dama das Camélias, de Alexandre } \\
\text { Dumas Filho (romance/tradução) }\end{array}$ \\
\hline 1890 & 1891 & 1892 & 1893 & S.D \\
\hline $\begin{array}{l}\text { * Elogio Histó́rico de Alexandre } \\
\text { Herculano }{ }^{66} \\
\text { * Marquesa das Índias (RH) } \\
\text { (publicado a pedido de um editor no } \\
\text { Pará, não vindo nenhum exemplar } \\
\text { para Portugal) } \\
\text { * As negociações com a Inglaterra } \\
\text { * A jóia do Vice-Rei } \\
\text { * Os portugueses na África, Ásia, } \\
\text { América e Oceania } \\
\text { * A lenda da meia-noite } 65 \\
\text { * As colônias portuguesas no } \\
\text { século XIX } \\
\text { * A descoberta da Índia, contada } \\
\text { por um marinheiro } \\
\text { * A ruína da Inglaterra, de C. } \\
\text { Debans (outros/tradução) } \\
\text { * John Bull e a sua ilha, de Max O' } \\
\text { Reill (romance/tradução) } \\
\end{array}$ & $\begin{array}{l}\text { * Prefácio do Amor de Perdição de } \\
\text { Camilo Castelo Branco (CL) } \\
\text { * Daqui a cem anos, de E. Ballami } \\
\text { ( romance/tradução) } \\
\text { * Honra de artista, de Octavio } \\
\text { Feuillet (romance/tradução) }\end{array}$ & $\begin{array}{l}\text { * Os descobrimentos portugueses e os } \\
\text { de Colombo } \\
\text { * Um enredo a Calderón } \\
\text { ( publicado juntamente com O } \\
\text { naufrágio de Vicente Sodré) } \\
\text { * O naufrágio de Vicente Sodré }\end{array}$ & $\begin{array}{l}\text { *Migalhas de história portuguesa } \\
\text { (História) }\end{array}$ & $\begin{array}{l}\text { * O marquês de La Seiglieri de Júlio } \\
\text { Sandeau (romance/tradução) } \\
\text { * A descoberta da terra, de Júlio Verne } \\
\text { (romance/tradução) } \\
\text { * História de Roma, de Victor Duruy } \\
\text { (História/tradução) } \\
\text { * Lição Cruel (teatro) } \\
\text { * Elvas } \\
\text { * O monge do Bussaco: episódio da } \\
\text { invasão Francesa } \\
\text { * A vida e as aventuras de Robinson } \\
\text { Crusoé, de Daniel Defoe } \\
\text { (Romance/traduçãa) } \\
\text { * Prefácio às Cartas do outro mundo, de } \\
\text { Francisco Palha }\end{array}$ \\
\hline
\end{tabular}

${ }^{164}$ Lido na sessão pública da Academia Real das Ciências de Lisboa em 15.06.1890.

${ }^{165}$ Incluído o conto fantástico Julieta, publicado anteriormente em folhetim, por meio da técnica narrativa de mise en abyme. 